\title{
The Pursuit of Wholeness in Maurice Gee's Fiction for Children
}

\author{
Vivien Jean van $\mathbf{R i j}$ \\ A thesis \\ submitted to the Victoria University of Wellington \\ in fulfilment of the requirements for the degree of \\ Doctor of Philosophy \\ in English
}

Victoria University of Wellington

2008 


\section{Acknowledgements}

This dissertation would not have been possible without the loyal and generous support of my supervisor, Dr Kathryn Walls. She has been unstinting in her guidance and criticism, and endlessly patient throughout six years of endeavour whilst I have been in fulltime employment. Her advice on all matters of content and style could not have been more thorough, and her tactful suggestions on how to deal with adult concepts present in novels that are written for children have on more than one occasion saved me from myself.

I would like to thank family, friends and colleagues who have patiently listened while I have expounded my ideas. Chief amongst these is my daughter, Dr Inge van Rij. In what is known as a role reversal situation, she has taught me to be unfanciful and disciplined. My heartfelt thanks are due to my parents who had little opportunity to pursue a tertiary education and who always helped me through difficult times. Thanks also to the staff in the library at Victoria University of Wellington College of Education who so willingly and quickly tracked down various sources, to Harry Ricketts for his scrupulous editorial comments, to Vincent O'Sullivan for several stimulating conversations, and to Susan Kaiser for her skilful proofreading and formatting.

Above all I would like to thank Maurice Gee for his willingness to be interviewed in person and on the telephone, and especially for his novels which have given me hours of pleasure and not a little puzzlement. I have read them in bed during winter weekends, on the beach during summer weekends, and at the computer all year round, and have found in them the dark and the light; "the broken arcs [and the] perfect round $[\mathrm{s}] "$. 


\begin{abstract}
Towards the end of Maurice Gee's Prowlers Noel Papps comments: "A morning on my sundeck passes like the turning of a wheel. Time present and time past, now and then, bring their motions into agreement and I know the joys of congruency" (p. 217). ${ }^{2}$ Here Noel describes a fulfilment which is circular and in which antitheses are brought together in harmony. A scientist, he has not always felt such joy. For much of his life he has been concerned with breaking things down and analysing them according to dry chemical formulae. Yet this process has been necessary for understanding, and in effect for creating the whole novel he narrates. Noel Papps seems to reflect Gee who is also concerned with division and forming a whole rounded book.

This thesis examines Gee's concept of parts and their possible congruency. The Introduction considers Gee's novels for adults, especially those in which protagonists, speaking for Gee, describe the process involved in creating a whole work, whether literary, non-fictional or artistic. Their descriptions contextualise my exploration of Gee's pursuit of wholeness in his fiction for children. I turn first to the $O$ trilogy in which the Motherstone is an explicit image of balance. Thereafter the focus is on Gee's five historical novels, in which the presence of lived experiences, real history, allusions to creative works, characters' illusions, and the universal are considered at length. Drawing on interviews, photographs, archival material, and non-fictional, historical, and literary texts, I attempt to establish the authenticity of Gee's reproduction of these dimensions and, where there are discrepancies, their effects. The narrative technique involved in bringing diverse dimensions together is also examined. Finally I consider patterning across Gee's five historical novels as a representation of a whole work.
\end{abstract}




\section{Contents}

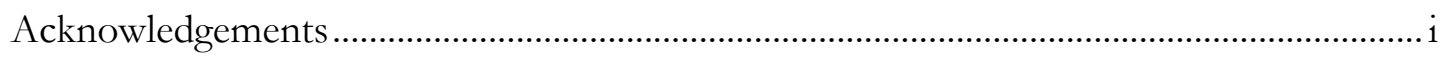

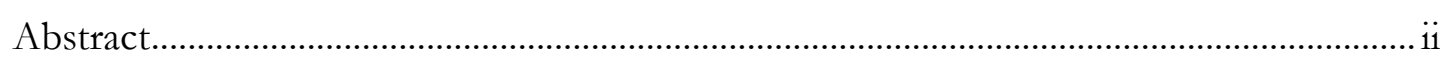

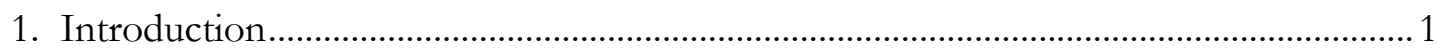

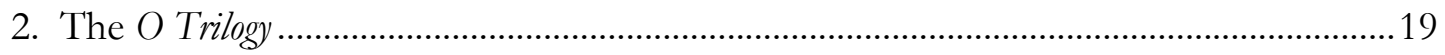

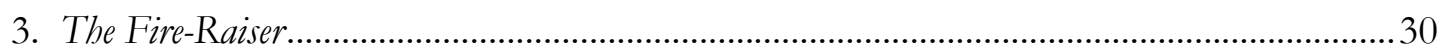

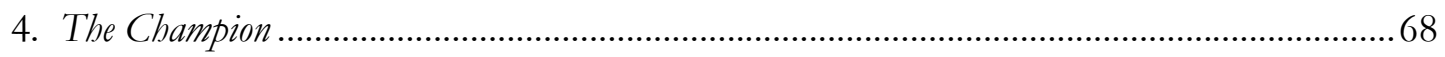

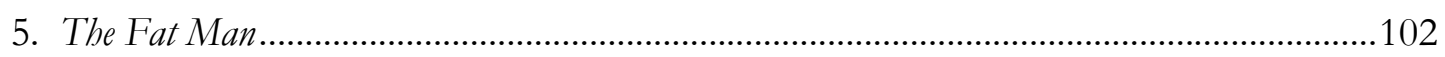

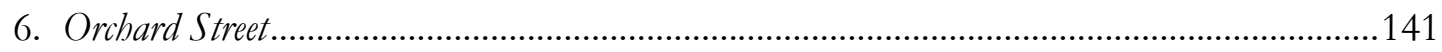

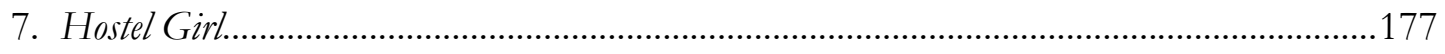

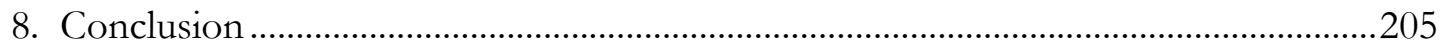

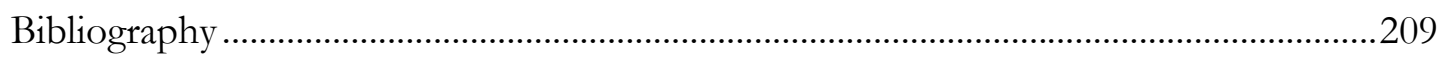

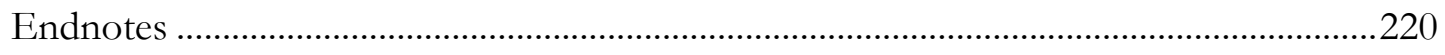

\section{Figures}

Figures 1 to 12: Landmarks of Henderson (photographs).............................................138

Figures 13 to 20: Newington Road (photographs)............................................................175

Figures 21 to 24: The Hutt Valley (photographs) ……………………………................204 


\section{CHAPTER 1}

\section{Introduction}

\section{Defining Wholeness}

In his five realistic novels for children Maurice Gee sets out to help the New Zealand child reader understand the past that has shaped him or her and the contemporary world. Step by step the five novels cover defining periods in New Zealand history. They document real locations, people, and events during two world wars, the Depression, the Cold War, and the mid-fifties. Gee's five fantasy novels also include much that is to do with war and, indeed, may be analogous to war. Many of Gee's novels for children could almost be read as history books whose intention is to provide the reader with a factual account of the past. But during a debate about history in Games of Choice, one of Gee's earlier novels for adults (first published in 1976), Bart Somers, the local historian, makes ironically explicit the limitations of a scientific approach to the past: "History is more science than an art [... I. It's the search for the pure incontrovertible fact. Rather like dissection. One lays each part out to see - one makes a list, an inventory. But no interpretation. No 'intuitive leap'. That's novel-writing, not history. [ ... $]$ Fact alone is pure" (pp. 87-88, 91). ${ }^{1}$ As a novelist, then, Gee is interested not simply in history as science, pure fact, or dissection, but in history as interpretation and intuition. Indeed, the re-naming of the settings of Nelson and Henderson as Jessop and Loomis frees Gee from fact and allows him to write fiction. As fiction, the novels for children include characters, places, and events that are often, to use Gee's words, "absolutely straight invention". Gee also shows characters interpreting history, responding to it emotionally and imaginatively, and experiencing dreams of longing or despair. Far more than any textbook history, then, Gee's novels are concerned with human psychology and, as Rex Petley puts it in Going West, with letting the eye "look inside and back" (p. 279). ${ }^{3}$ It is not only what is revealed about the past that is of interest, but also what is revealed in terms of Gee's ideals. As I shall argue, what links these dimensions is Gee's preoccupation with wholeness.

In Gee's writing wholeness has various applications. Indeed, the very choice of historical realism as a genre in which to write suggests the ideal of combining fact and fiction to make a unified whole. As Nathan Uglow has pointed out, the historical novel is a "hybrid genre [that is] based upon the assumption that history and fiction are categories that overlap each other and that therefore appeal to and derive from an originally unified experience of the world". Thus, Uglow notes, the historical novel reveals the confusion 
of public and domestic, personal psychology and impersonal historical forces, and dry historical fact and literary melodrama. ${ }^{4}$ These comments apply to Gee's fiction in which, as described by W. H. Oliver, "The private, the intimate, and the public intersect and clash [and] the equal and conflicting necessity of both inner and outer worlds is held in a balance". 5 Furthermore, that Gee, through allusion and analogy, explores history far beyond the periods of the books' settings, seems evidence of an attempt to give the New Zealand child reader a view of the whole human race. And in reconstructing history for children Gee is concerned with balancing a sometimes alienating adult reality with what will appeal to (and can be tolerated by) younger readers.

Central to Gee's concept of wholeness is thus a concept of disparate parts that are to do with fact and fiction, the private and public, and adult reality and child appeal, and that must be brought together and held in balance. Gee also sees the human personality in terms of parts and wholes. For example, he has referred to F. G. Gibbs (headmaster of Nelson Central School in the early twentieth century, and the model for Clippy Hedges, the headmaster in The Fire-Raiser) as "a man of so many parts it is impossible to enumerate", and as "a character presented to me whole". ${ }^{6}$ Gee seems to associate the whole diverse personality with fullness and circularity. As he has commented in his Margaret Mahy lecture, in creating fictional characters in the five realist novels, he has been concerned with their "fuller development", and he has seen Rex in The Champion as a "fully rounded character", and Herbert Muskie in The Fat Man as "fully imagined". That the fictive process contributes to wholeness and gives characters substance or weight, has been implied by Gee when speaking of his books as proceeding by "invention", but "anchored by the imagination". 7

Gee apparently believes that the whole personality can best be depicted through the extended form of the novel. He has spoken of the novel as "a whole text", of "an interest in whole lives rather than in parts of lives [and of getting] a sense of wholeness, and [shaping] something well". ${ }^{8}$ Gee also seems to believe that a whole personality is essential for the writing of a novel. He has referred to his position as author in terms of centrality and stillness, and the drive from ideas that are incomplete towards what presumably will be the completed work: "I work in there and maybe from a still centre I find a place where all these bloody half-baked ideas of mine go towards". By his own admission Gee equates wholeness with technical achievement, balance, depth, and reversal: "I shift about in time, to begin with, I put part against part to generate tension and find balance [...]. I spend a lot of time in people's minds at different levels [...], the vertical shaft goes down, the narrative doubles back". ${ }^{10}$ And it seems to be a balance between parts that Gee refers to when he describes "the struggle to organise the book and keep the proportions right". ${ }^{11}$ 
Gee has referred to his own tendency to see life as divided into parts. For example, in his lecture "Creeks and Kitchens" he claims that the title underlines "the essential duality that every writer must know: familiarity/mystery, safety/danger, dark/light, good/evil". ${ }^{12}$ In creating a novel, then, and in generating tension in order to find balance, Gee uses parts that are strongly opposed. And if parts are not strongly opposed, Gee will make them so, as he has acknowledged by putting a Nelson arsonist (the model for Marwick) and the headmaster F. G. Gibbs "in opposition to each other" in The Fire-Raiser - a process that involved simplifying the original models. ${ }^{13}$ Indeed, the viewpoint in Gee's novels is sometimes unbalanced. This is to say that Gee is concerned with redressing an historical imbalance, in which case he provides a corrective, as he has in creating the aforementioned opposed characters, with one compensating for what the other is not.

Gee's interest in opposed characters has been recognised by Lesley Monkman in her article "From Plumb to Prowlers: Maurice Gee's Octogenarians". Monkman contextualises her comparison of George Plumb and Noel Papps and their dualistic worlds by referring to William James's essay in Pragmatism. James, Monkman notes, "characterises the tendencies of two 'temperaments' and lists dominant traits even as he insistently acknowledges the dangers of simplistic oppositions". Monkman goes on to list traits connected to George Plumb whom she sees as James's “tender-minded, rationalistic (going by principles), intellectualistic, idealistic, optimistic, religious, freewillist, monistic, [and] dogmatical". Noel Papps, on the other hand, is seen by Monkman as James's “tough-minded, empiricist (going by facts), sensationalistic, materialistic, pessimistic, irreligious, fatalistic, pluralistic, [and] sceptical".

Monkman also recognises the emphasis in Prowlers on oppositional elemental imagery and the balanced character constellations formed by "Tup Ogier's 1915 quartet", that these encourage the reader "to contrast the central characters", and that Gee creates a "combination of insistently obvious parallels". In establishing symmetrically organised character groupings, and paralleling them on human and astronomical levels Gee extends the concept of wholeness to embrace not only individuals and the entire cosmos, but also the interconnections between them. However, Monkman acknowledges that Gee is "too good a novelist for any neat slotting of his characters into reductive schemes". ${ }^{14}$ Moreover, Gee himself has firmly stated that he has "always tried not to do absolute black and white, and to get [ . . ] shades of grey into the picture as well". ${ }^{15}$ He has claimed that The Fire-Raiser is not "a simple tale of black and white. The villain is more than villain, he's thoroughly human, and in the end pathetic - rather like Herbert Muskie in The Fat Man". ${ }^{16}$ Whilst 
establishing parallels between the cosmos and symmetrically organised, opposed characters, and generating tension between these, Gee simultaneously depicts characters as mixed individuals.

Gee's ideal of a wholeness comprising opposed but mixed parts that occur on macrocosmic and microcosmic levels can be clarified by a brief consideration of Jungian depth psychology with which Gee seems well acquainted. Indeed, Jung and Jungian terminology are explicitly alluded to in many of Gee's novels. For example, Wendy Philson, a character in Plumb, notes on paper for a deaf Plumb: "I'm reading Jung. All about the interpretation of dreams". ${ }^{17}$ As Plumb observes: "She wrote on at length about the dream as the key to the world of one's psyche, the dream as empirical data" (p. 237). Similarly, Jung has written: "The journey through the psychic history of mankind has as its object the restoration of the whole man, by awakening the memories in the blood". ${ }^{18}$ And in chapter five of The Halfmen of $O$ Marna refers to a time when "there was no law, only chaos" of which she has "but a memory in the blood". 19

In particular, Gee echoes Jung's terms for the psyche's divisions. Jung bases these divisions on the traditional numerological significance of the quaternity (as in the four seasons, four directional points, four elements, and four humours). His concept of "the 'shadow' [as] containing the hidden, repressed, and unfavorable [or nefarious] aspects of the personality", is recalled in Ellie's search for the "shadow" as is suggested in the title and themes of Ellie and the Shadow Man. ${ }^{21}$ Jung named the "protective cover or mask [ . . .] that an individual presents to the world" as "the persona", ${ }^{22}$ and Paul Prior refers to his public façade as a "persona" (p. 101) in In My Father's Den. ${ }^{23}$ Jung argued that the consequences of a split psyche are apparent when a primitive "beast breaks loose"24 and that a knowledge of the "regulating center" called "the Self" is crucial in preventing this. ${ }^{25}$ And in Motherstone the speaking stone describes to Susan the presence within Humankind of ancient origins, "the swamp beast", and the "dark place where self is all". ${ }^{26}$

Gee's view of the psyche as ideally a whole that integrates and balances opposites resembles Jung's. Jung saw the psyche as spherical, and as divided into two opposed parts: the conscious mind on the surface, and the inner area of the dark unconscious wherein lie primitive instincts and the collective history of humankind. In pitting Hedges and Marwick against each other, Gee echoes Jung's psychic structure and the internal divisions of each character on a larger scale, with Hedges aligned to the rational conscious mind, and Marwick aligned to the dark unconscious. Jung divided each of these areas into two sets of paired opposites: the ego and shadow, and the persona and soul, thus forming a quaternity. In establishing "balanced character constellations" such as “Tup Ogier's 1915 quartet”, Gee echoes Jung's quarternal divisions. As we shall see, 
in In My Father's Den each of the four main characters has traits more predominantly associated with one of these separate areas of the mind. Fulfilment, according to Jung, occurred through "individuation" - a process by which the psyche's paired opposites become integrated as one whole. That Gee's symmetrical groupings of opposed characters are so closely entwined, and exchange personality traits, contributes to their collective function as a representation of an integrated whole. Jung's ideal of fulfilment, oneness, harmony, unity or totality (terms he used interchangeably with wholeness) was expressed in the naturally emerging image of the mandala. A circular structure with a clearly defined centre, the mandala represented the ultimate goal and perfect balance in the formation of the individual's harmonious relationship with his/her Self. ${ }^{27}$ The mandala is echoed in Gee's most explicit image of wholeness - the $O$ trilogy's Motherstone.

The Motherstone (discussed in chapter one of this thesis) also resembles the Daoist Yin Yang symbol. Certainly, in Sole Survivor Gee reveals his awareness of Daoism when he parodies the Yin Yang as the "Zin Zang" (p. 15), and seemingly he has a similar view of wholeness. ${ }^{28}$ The Yin Yang, a circular shape with two distinct halves, one white, the other black, divided down the middle by a curved line, works on microcosmic and macrocosmic levels to stand for the harmony of the individual, and of individuals and the cosmos. Its two sides represent all dualities: dark and light, female and male, moon and sun, passive and active, and so on, whilst each side contains an element of the other, suggesting that no phenomenon is completely devoid of its opposite state. Thus yin and yang are complementary opposites that are integrated and interdependent, with each representing the whole whilst simultaneously contributing to the greater whole. Most importantly, the curved central line suggests the continual movement between the opposed halves, and that they operate in an "eternal cycle of reversal" to represent continual change and perfect balance. ${ }^{29}$

Individually and collectively Gee's characters can be considered in terms of the yin and yang. Characters are opposed to each other, but are also mixed. In that each character includes an element of the other, is inextricably interwoven with others, and moves in tangency with others, they form patterns of continual reversal and change. (Indeed, Gee has commented that he is "always looking for a word that [ . . . ] will suddenly reverse things". ${ }^{30}$ ) Closely integrated with each other during the course of a novel, they collectively represent wholeness whilst individually they may be incomplete. Notions of a wholeness that involves redressing an historic imbalance, the tension or balance of mixed opposites, continual change, integration and harmony are key to Gee's novels and to his preoccupation with what Jung has described as the "journey through 
the psychic history of mankind [which] has as its object the restoration of the whole man". ${ }^{31}$ As I shall demonstrate, Gee's pursuit of wholeness is as prevalent in the fiction for children as it is in the fiction for adults.

\section{The Adult Fiction and Author and Artist Protagonists}

In Gee's adult fiction where the protagonists are authors and artists, the pursuit of wholeness is accompanied by a struggle for technical achievement that parallels Gee's own. The depictions and musings of these characters are therefore useful in establishing the nature of Gee's ideology.

For Paul Prior, the English teacher and author-narrator of In My Father's Den, wholeness involves acquiring knowledge from books by (among others) George Eliot, Dickens, Dostoyevsky and Whitman. ${ }^{32}$ These provide Paul with versions of himself and he recognises his own murderous instinct in Fagin from Oliver Twist. But books and the den in which they are housed also allow Paul an escape, especially from his mother's rigid Puritanism, from his brothers (one of whom is mongoloid), and from the risky emotion of love. As Paul comes to realise, "I've been incomplete. I've got this sense of being hollow. I keep shifting from thing to thing. That's why I have a den. To stop me being completely slippery. Lightweight" (p. 131). At least as significant as books is Paul's personal history, which will give him weight and balance. Finally, however, Paul mourns his "poor, burned books" (p. 175) more than the murdered Celia whom he came close to loving. He thus remains incomplete.

In Plumb intellectual energy assists, but also hinders, the attainment of wholeness. Like Paul, George Plumb pursues enlightenment by reading widely across religious material, literature, and philosophy. Plumb believes he develops "a consciousness of the life and order of the universe, an intellectual enlightenment, a state of mortal exaltation and quickening of the moral sense, and a knowledge of immortality". But in fact Plumb mythologises himself as part of a divine plan that excludes what he terms "man's dual nature", particularly its "lower part" (p. 198). Confronted with his son's homosexuality, Plumb faces an abyss that defies light and exists in his own dark nature. Embodied by an impression of himself as a "frightful beast", and his son and the lover as "unclean [and] filth" (p. 200), this abyss is expressed in his furious urge to kill: "It was my right to kill [Alfred], kill the beast, as God had killed those creatures of filth long ago" (p. 201).

Walt Whitman's The Song of Myself (which celebrates male physiology and, implicitly, homosexuality) gives Plumb a context for understanding darkness. He sees in the poem a pattern that reflects a whole life, including its opposed but interdependent parts, one of 
which is dark. He realises that "In the mystical state all [is] not joy, that dark and light [are] complementary parts” (p. 240). Plumb breaks Whitman's Song into five parts, each of which he further divides and examines, and focuses on the section "Dark night of the Soul". He then reconfigures the parts into a whole. Having seen the dark within the entire plan, he recognises three complementary dimensions to his life: "A knowledge and acceptance of [his] own nature; a knowledge of the Cosmic order; and a fixed memory of [his] glimpse of God" (p. 241). These dimensions represent the whole Plumb has been seeking.

Meg (Plumb's youngest daughter) experiences stages similar to those of Paul Prior and her father. Like Paul's books and Plumb's cosmic consciousness, Meg's initial romanticism allows an escape from the mundane. According to her father's opinion (expressed in Plumb) she has "the artist's type of mind [... . She sees particular things [...]. And [she] transforms them imaginatively". But Plumb adds, "This is not the whole creative act. [... ] She fails to find language" (pp. 245-246). However, through writing her novel Meg (the sequel to Plumb), Meg herself gains "a better sight", discovers language, abandons her tendency to "take shapes blurred with [ . . . ] feelings for real things" (p. 215) and acquires "a more usual eye" (p. 11) that has a "long sight and [ . . ] a wide lens" (p. 227). ${ }^{33}$ This larger view involves finding others and her self in memory, and freeing others from herself. Paradoxically, Meg attains fullness as well as emptiness and release. As she notes in the novel's final chapter: "I have not been alone, in my furor scribendi. I have had more company than I have known what to do with. They are leaving me. [ . . ] In a curious way I am both empty and full” (pp. 249-250). Knowledge of self and also selflessness are, Gee seems to say, necessary for wholeness.

In Sole Survivor (the final volume of the Plumb trilogy) Raymond Sole is immersed in the darkness Plumb evades, and it is the light and order Plumb found more easily that are needed to make him whole. In chapter fourteen, when perceiving opposed worlds, Raymond realises they are the same. The first, known world reflects his corruption: "The eel pools [are] dirty now with rubbish from the houses. [ . . ] A smell of rot [comes] from the water". The second unknown world would have been familiar to the romantic Meg: "A world impossibly green; the magic world children in books step through mirrors to, through waterfalls and doors in trunks of trees. Faery world". As Raymond realises, they are the "same magic world. They're interchangeable" (pp. 139140), and the difference is one of perception. Thus in cancerous old age Raymond discovers art, order and light within dark primordial nature and the tranquillity of a balanced whole: 
Today I heard the rainbird - that urgent little song. It's beautifully exact. There's a knowledge there millions of years old. Before long rain hung in the gorges. The sun made a piece of rainbow in the curve of cliff down-river from me. Here is a place human will does not contaminate. I am gone from it but it's there, lying in the night. I can't imagine it. Imagination cannot touch it either. (p. 217)

As Raymond comments, the will contaminates, and imagination may do something similar. Paul Prior, Plumb, and Meg, each has an over-energetic mind that distances him or her from reality even whilst formulating it. Such is also the case with Noel Papps in Prowlers. A chemist, Noel is highly intelligent, sceptical, adept at measurement, and self-reflexive. But in chapter two he self-mockingly warns of a forced balance whilst ironically forcing a formulaic balance on life:

I'd better get us down in our right balance. Algebraic symbols would help, Kitty as x, Phil as y, and so on, and then I could compare and bind together, and display us in our proper magnitudes; and Tup and Le Grice could come in; others too, Lotte Ogier (a subtraction from Lotte Reinbold), and the Gasman, Les Dockery, a negative number, and a dozen others, and I might end up with an axiom. (p. 5)

Thus, like the previous protagonists, Noel uses an ordering mind to evade darkness and death. Parodying sexual and romantic love he projects onto a skeleton his obsession with measure, symmetry, balance, and weight:

I [ . . ] spent my time with Miss Montez, stroking her, poking my fingers in her apertures. She had lovely fingers, she had lovely toes, and a pelvis like a gravy-boat. Beautiful joints Tup rubbed them with mutton fat - and a curve in thigh and forearm no woman with flesh on her has ever equalled, not for me. The measured knitting on her skull could not have been done better with a machine. Her eyeholes had a symmetry and balance that made me want to weigh and measure them. (p. 8)

But through Noel, Gee reiterates that real balance evolves when, having brought parts together and measured them, one lets go of self. In chapter forty-nine Noel becomes aware that life cannot be measured: "Each thing has its weight. That is what concerned me in my work. A life though isn't measured in that way." Through becoming spontaneous - even forgetful - Noel finds life's parts fusing together naturally to form a tranquil whole: "A morning on my sundeck passes like the turning of a wheel. Time present and time past, now and then, bring their motions into agreement and I know the joys of congruency" (p. 217).

As an artist, Ellie Crowther in Ellie and the Shadow Man discovers that balance involves dualities: "Her lessons were full of things in pairs: exploitation/hunger, empire/oppression, brotherhood/peace, with stories that seemed personal to accompany them. Ellie loved the way they balanced out and made her see" (p. 48)..$^{34}$ But Ellie learns that simply seeing connections does not denote wholeness. Like the other 
protagonists she forces an order on nature, as is apparent in her art: "She [...] drew the orchard leaning down the slope and flattening out, the hills like arms, the sea like a plate, the two coasts and the two mountain ranges - all parallel and neat, with too much likeness. She had not let things be themselves" (p. 98).

Ellie recognises that a regularized nature is simplistic, and that life is often random and complex: "The truth of [her painting] was in the lines: lines making shapes and the shapes balancing. How had she seen that, looking at the hills? Nothing had been balanced there. She had simplified" (p. 158). As Ellie later tells herself "shape is a bird" (p. 318). She realises that wholeness can be attained through recognising the interrelatedness of herself and the world, and that "what's inside changes what's out there, and vice versa" (p. 246).

A subsequent painting has the underlying dimension that previous ones lacked. It depicts "the real world [which] is a shadow behind the substantial one she makes on canvas" (p. 247). Ellie thus acknowledges a depth to nature that universalises and involves order and "image or myth or symbol [...] something that people looking at paintings share. Without effort. From a kind of deep acquaintance" (pp. 306-307). Finally Ellie envisages a painting that involves shape, symbol, balance, weight, and stillness: "The man in the river no longer drawing everything into himself. He stood right of centre, where the eye would start and where it must stop, but now there were people balancing him; the shingle bank held its proper weight, the trees and hills took their place by right. She saw the colours she would use to hold him still” (p. 309).

In the novels for adults, then, each protagonist, whilst located in the present, looks backwards to history and inwards to the mind and engages with three broad dimensions the particular, the cultural, and the universal that must be integrated for the achievement of personal wholeness. By showing these dimensions and characters to be manifestations of each other Gee, like his protagonists, looks backwards and inwards to gain a picture of the whole psyche. As W. H. Oliver has put it: "Gee [...] merges the universal and the particular" and, as Lauris Edmond has claimed, in Gee's novels oppositions "knit together to make a richly textured whole". ${ }^{35}$ This is the sort of balance Gee pursues in his novels for children.

\section{Characterisation}

Gee associates wholeness with character. In chapter twenty of Sole Survivor Raymond Sole who is writing a biography, does the same, as he tells his Aunt Felicity towards the end of the novel: 
'Everything's there. The work's all done. But I can't bring it together.' I could not make a whole round life. I lacked the stillness and the breadth; I lacked the measure. I had the energy for it but found that I needed tranquillity too. (p. 199)

Here Gee implies that the author's personal wholeness is needed to depict characters that are whole, and that these factors are associated with narrative technique. Certainly Gee strives to include "everything" in his books. He aims, as he has commented, "to put in, not leave out, [and to] suggest fullness not emptiness". ${ }^{36}$ Like Raymond he seeks stillness, breadth, and measure, to exercise energy yet achieve tranquillity, and to form antitheses into a rounded whole. As a further exploration of the adult fiction shows, characterisation is marked by similar features and occurs in several ways.

First, Gee depicts characters who together create patterns suggesting wholeness, but who have the potential to change. They are positioned within symmetrical groups and between conflicting beliefs and mental states as embodied by other characters. Paul Prior is in conflict with his two brothers (the Puritan moralist and the amoralist) and friend Charlie (the pragmatic atheist). Each in dubious ways is connected to Celia (the novice intellectual) who in turn is torn between the two father figures, Charlie and Paul.

Second, individual characters are also mixed, whilst the view we are given of them is complex and whole. Paul Prior describes his brother using a metaphor of disjointed circularity that suggests Andrew's split self: "A diagram of his universe might be made up of two over-lapping circles, the perimeter of each enclosing the centre of the other. In one circle things of the spirit: a stern God, a merciful Christ, and Mother, combining these attributes (a kind of Holy Ghost). In the other: bank account, house, car - Paul Prior squeaking at the outer rim [... ]. Andrew lived in the common ground" (pp. 164-165).

Third, opposed characters have much in common. Paul and his brother Andrew share the Venn circles and also the effects of their mother's rigorous Puritanism. Indeed, all three brothers are parallels to the protagonist in Paul's book - Dostoyevsky's The Idiot. Characters therefore share the same interchangeable parts and undergo patterns of exchange. They conclude in positions maintaining overall balance, but that are the reverse of how they began. For example, towards the end of In My Father's Den Andrew and Paul in different ways reflect their younger brother's ugliness. Mentally crippled, Andrew murders Celia, physically crippled Paul observes: "I was running down the hall the way a chimpanzee runs [ . . ]. I do remember the idiot clapping of my bone-dry shirts as I went on my simian run" (p. 173). Through creating opposed characters who are similar and undergo change and exchange, Gee suggests breadth and movement and, like Raymond, gets "everything” there (p. 199). 
Fourth, Gee extends individuals' perceptions of themselves as fictional characters to form ironic parallels. Paul's reading of Dostoyevsky's The Brothers Karamazov and The Idiot and Ben Jonson's poem "Celia" influences his perceptions of himself, his brothers, and Celia, and impacts on their behaviour: They become ironic versions of the fictional characters. Similarly, a middle-aged Casaubon (from Eliot's Middlemarch) or Casanova, Paul woos Celia who parallels Eliot's youthful Dorothea, and Casanova's daughter. ${ }^{37}$ As composites of several roles, characters become emblems. Fastening them still within the novel Gee achieves the tranquillity sought by Raymond.

In characters' emblematic roles within symmetrical groups, Gee forms a picture of the whole human being. In the four complementary types central to In My Father's Den Paul is ego/hero (or anti-hero), Andrew is the shadow/villain, Charlie is persona or public veneer and Celia represents innocence and the soul. ${ }^{38}$ It is the protagonist who must resolve the conflict of the four, and in effect integrate them into one whole. As mixed individuals, as interrelated parts of a whole, and as emblems, single characters are complex and mobile, yet simple and still. As we shall see, in the novels for children characters operate in similar ways.

\section{Fictional and Mental Structures}

Gee's comment in a 1987 New Zealand Listener article that he "wanted to get away from the novel enclosed in itself and write something that overflowed, that connected with life outside the pages" is applicable to interrelationships between his novels. ${ }^{39}$ Thus patterns go across novels, with repetitive versions of different characters (often with similar names, like Paul Emerson Prior and his mother Edith in In My Father's Den, and Emerson and his mother Edie in Plumb). The Plumb trilogy is the most obvious example of recurring crossovers, with families of three generations appearing in at least two, if not all three, of the books. As Bill Manhire has noted, characters such as Fred Meggett, Duggie, and Plumb are similar - all have little sense of people outside themselves. That Gee is not content simply to depict a single individual or family, but instead a family saga involving several generations, suggests that an entire context is part of the wholeness that he pursues. Manhire has also noted that the family saga occurs over a trilogy rather than in one novel, allowing for multiple points of view and overlapping parts. A resonant truth involving contradictions is being explored, as well as a whole journey from innocence in Plumb to "the still, sad music of humanity" in Meg to disillusionment in Sole Survivor, with accompanying variations of tone. What Gee seems 
to insist on is that a truth that is whole is a matter of infinitely altering perspectives, as is true of history itself. ${ }^{40}$

Aside from fusing antitheses, Gee establishes stillness through each protagonistnarrator who looks backwards and inwards. Paul, Plumb, Meg, Raymond, and Noel are older characters through whose memories Gee shifts about in time. The narrative doubles back from the present time in which the protagonist is thinking or writing, into particular, cultural, and universal history. For example, In My Father's Den starts with two published articles on Celia Inverarity's murder on May 13, 1969. From there Paul Prior reviews events from 1928 leading up to this deed, and considers them within historical and literary contexts. Finally, with the return to a present in which the past is now known, the way is paved for integration. Moreover, the older narrator's point of view provides a circular frame that surrounds and effectively holds antitheses and action still. The epilogue at the end of Paul's book perfectly balances the prologue at the beginning. The novel therefore has substance, symmetry, and circularity, and embodies a whole whilst reflecting the structure of the narrator's mind.

\title{
Narrator-Protagonists and Language
}

Gee has commented on the importance to him of language:

\begin{abstract}
You're working in units - the word, the sentence, the paragraph. The unit of meaning that interests me most seems to be the paragraph, but within that is the sentence, and within the sentence the word, that one has to encompass and get in proper shape. I look for the dictionary meaning of words, and only when I've established that do I feel comfortable with them, so that I can move on to the point where they quiver and shimmer, reverberate a little - but until I've established the exact meaning I'm not happy about it. ${ }^{41}$
\end{abstract}

The above quotation reveals through its very structures Gee's ideals of wholeness. Using chiasmus, Gee refers to units which move from the particular (words) to the more general (sentences and paragraphs). The statement thus mirrors itself and is symmetrical and balanced. It notes the parts that make up the whole, and that the whole is made up of parts. Indeed, as Gee explains, words take on a meaning beyond the exact. That he sees them as shimmering and reverberating suggests they have a resonance. Having depth and symmetry, language apparently plays an active part in Gee's pursuit of wholeness. Recognising this depth, Lauris Edmond has claimed that the surface of Gee's prose is hard and clear, but it shows some "inner complexities from which rise the springs of behaviour". ${ }^{42}$ Indeed, we see that wholeness, or a lack of it, is apparent through the author and artist protagonists' linguistic and painterly structures. 
For instance, an over-indulgence in linguistic devices hinders some protagonists' balance. As a storyteller and English teacher Paul Prior in In My Father's Den is interested in words. But "a figurative habit of mind" (p. 14) allows him to display his learnedness and avoid emotional commitment. Even in the epilogue he uses metaphor to posture as storyteller: "I live in a house by the sea in Nelson Province. It's here I've written this story - cultivating my garden, so to speak" (p. 175). Figurative language, therefore, gives us a whole view of Paul, but it also reveals his failure to achieve wholeness.

Gee thus allows characters to reveal themselves through their own words. As Manhire has noted: “George Plumb's own metaphors supply a running commentary on some of the contradictions of his life - he is a pacifist who uses an astonishing number of images of battle". 43 Unlike Paul, Plumb relinquishes metaphor. His inner harmony is apparent in the simple diction, balanced opposites, and acknowledgement of uncertainty in his final statement: "I thought, I'm ready to die, or live, or understand, or love, or whatever it is. I'm glad of the good I've done, and sorry about the bad'" (p. 255).

Meg, of course, is engaged in writing the novel we are reading and seeks balance through her words. Manhire comments: "Her sense of wholeness depends [ ...] on her artistic competence" - it is the activity of writing "which helps [her] become whole". ${ }^{44}$ In this she resembles Gee. Concerned with doing away with sentimental rhetoric she abandons metaphor as a device connected to the will: "The figure I see is an hour-glass. With Robert's burial the last of the sand trickled through. By an act of will (but an irresistible act) I up-ended myself. I let it all trickle back. The story ends. I want very much to be quit of that metaphor" (pp. 249-250). Her final thoughts, like Plumb's, are expressed in simple words: “That's what I've come to hope for in the last few hours. Not a large hope, surely; and one that has no undue sentiment in it" (pp. 250-251).

However, some author-narrators must find metaphor. In Sole Survivor Raymond, like the older Meg, tries to shed superfluous speech. Purity and truth, he believes, are in nouns: "My life has made me adjectival. I don't like that. The truth is in nouns and pronouns. Adjectives blur things, adverbs too; and verbs can falsify. Glenda. That's the truth" (p. 169). But putting aside this fundamentalist view, Raymond acknowledges he has followed journalism's narrow path. In the above quotation his taut sentences and ironic use of metaphor betray his lack of breadth and insight. In chapter twentytwo his tranquil, richer view (previously quoted) is reflected in his fusion of imagination and fact, and past and present. In recalling the ancient knowledge of the rainbird's 
"urgent little song" (p. 217), he uses poetic language, including metaphor, semi-formal syntax, and the adjectives and verbs he earlier tried to avoid.

Like Raymond, Noel in Prowlers is a purist and seeks truth in nouns which he claims represent wholeness and completion. But as a scientist he is concerned with the breaking down and bringing together of parts that he sees as the function of verbs and predication:

To know the name of things is my desire; our only proper knowing is through names. Circles are completed in the noun, margins and boundaries are clear, and we are free from vagueness, free from fear, with every object known from every other. The name, the name, is the single proper epithet.

And having said that, what about the verb? Isn't breaking down and building up the thing that chemistry is all about? For I'm a chemist. Nouns create a landscape without movement or sound. Nothing happens. Verbs bring activity and change. Yes, I agree with that argument. But I see predication as closer naming. Noun and verb unite in my craft or science. (p. 9)

Noel is as limited as the younger Raymond, and the unity of which he speaks, although wittily debated, is only a concept. Gee (the master wordsmith) uses irony to give a complete view of Noel that reveals his lack of completion. For Noel's words, whilst saying one thing, do something different: The sentences refer to completion but, starting with conjunctions, are grammatically incomplete; and rather than still and measured, they jump from one subject to another. Also, Noel uses parts of speech other than nouns and verbs. In chapter forty-nine, his greater wholeness is apparent in his measured tone, use of the present tense that suspends time, and balance of opposed images, statements, views, form and content, and metaphor and nature:

Each thing has its weight. That is what concerned me in my work. A life though isn't measured in that way. How is it measured, how does it move? That's what I'm busy finding out. That's what I'm not busy finding out.

I'm not any longer compelled. I'm easy in my choices and casual in picking up this or that. I sit here and think about things and choose not to write them down; or I forget. (p. 217)

In Gee's prose, poetic features suggest underlying truths that may differ to characters' perceptions. A consideration of similar techniques in the novels for children will establish how Gee's use of language gives a balanced, rounded view of characters.

\section{Literature Review}

Given that Gee is internationally acclaimed as a writer for children, surprisingly little critical material exists on his junior fiction. In Maurice Gee (1986) Bill Manhire briefly 
discusses four of the fantasy novels and The Fire-Raiser, whilst focusing at length on Gee's fiction for adults. Manhire's comments on the significance of context to Gee's writing, and the presence within it of motif and image patterns, a cosmic emptiness, allusions to film and external texts, and a concern with language, have proved relevant to my study of the children's novels. ${ }^{45}$ Diane Hebley considers New Zealand junior fiction from 1970 to 1989 in The Power of Place. ${ }^{46}$ Within this framework her examination of Gee's junior fiction, its political analogies, and emphasis on the environment and duality has helped initiate my exploration of similar features.

Numerous book reviews provide largely uncritical information. However, Fleur Beale and Janice Marriot reviewing Hostel Girl in "Secrets and Lies" and "Stalker Story is Less Violent than Earlier Teen Chillers" have provided starting points for an exploration of the aforementioned novels. ${ }^{47}$ Writing in the New Zealand Listener Denis Welch discusses The Fat Man, Orchard Street, The Fire-Raiser and Hostel Girl, and emphasises the last two as forerunners to Prowlers and Ellie and the Shadow Man. ${ }^{48}$ Lawrence Jones considers The Fat Man and more fully Crime Story in "Most Significant Work in NZ Realism" whilst Brian Boyd looks at Under the Mountain within the context of all Gee's fiction. ${ }^{49}$ These reviews and articles have suggested connections between Gee's junior and adult novels, as has Louise Clark's excellent thesis, Writing Vertically and Horizontally: The Relationship between Maurice Gee's Fiction for Children and for Adults. Contextualised by a discussion of children's literature generally, and Gee's adult novels, Clark examines Gee's fantasy and realistic novels in terms of horizontal and vertical writing respectively. Clark's thesis came out in 2004 when I was quite advanced in my study, and anticipated my comparison of Gee's history of Nelson Central School with The Fire-Raiser. Her paper "Gee's Dangerous World" further explores the juvenile fiction's realistic dimension. ${ }^{50}$

Interviews with Gee tend to be repetitive, mostly focused on the adult fiction, and resistant to discussion of meaning or narrative technique. But speaking to Colleen Reilly in 1990, Gee refers to his junior novels within the context of his adult novels, and elaborates on characterisation, structure, and use of language. ${ }^{51}$ The writer's own comments on technique in the adult fiction are applicable to his writing for children which is far from the "horizontal, straight-line sort of storytelling" he off-handedly claimed it to be in an interview with Brian Boyd, published in 1992. ${ }^{52}$ In 2008 speaking on Radio New Zealand National about his most recent children's novels (Salt and Gool) Gee has noted that he puts in something for the reader to "chew on", thus seemingly verifying Clark's claim that, indeed, there is more than a straight-line plot to much of his junior fiction. ${ }^{53}$ 
Gee is happy to talk about his childhood. Reviewing The Champion in "A Champion Tale", Marion McLeod emphasises connections between its timeframe and setting and those of Gee's childhood home in Newington Road, Henderson. ${ }^{54}$ Sarah Stuart's article "Gentle Gee has a Grip on all Ages" suggests the replication of features of Henderson in The Fat Man, as does Alan Papprill in a series of lessons for secondary school students. ${ }^{55}$ Gee's autobiographical essays "Beginnings" and "The Way of a Writer", and his Margaret Mahy lecture, "Creeks and Kitchens", describe childhood influences on The Champion, The Fat Man and Orchard Street and he has also spoken about his childhood on Radio New Zealand National with Kim Hill. ${ }^{56}$ In interviews with Judith Holloway and Agnes Nieuwenhuizen, Gee similarly notes The Fat Man's origin in incidents during his childhood in Henderson. My own exploration of childhood influences on Gee's writing has been motivated by these publications. The Nieuwenhuizen interview and "Creeks and Kitchens" also include useful comments on structure. For instance, Gee “remind[s] those experts who 'don't understand the organic nature of a story' that in The Fat Man 'the troubling bits are held firmly in the structure of the story which carries on and resolves things" ${ }^{57}$

These remarks are made in answer to a series of letters to the editor, published over six issues of the New Zealand Listener in 1995, shortly after The Fat Man was awarded the Aim Children's Book Award for best junior novel. Dorothy Butler's initial letter claiming The Fat Man to be an "experience of unrelieved hopelessness" sparked off a debate that involved writers Jack Lasenby, Paula Boock, and Tessa Duder (also a member of the judging panel), and others defending or attacking Gee. ${ }^{58}$ A few years later Uta Purcell picked up on the debate. She applied criteria-based assessment to survey readers' responses to The Fat Man, and concluded that it was 'inappropriate as a junior novel". 59 Gee defends himself against Butler and others in his article "Territorial Imperative" in Quote Unquote. ${ }^{60}$ Tessa Duder recalls the debate in writing to the editor of the New Zealand Listener eight years later as does Steve Braunias who further records the connection between biographical material and Gee's fictional world of Loomis. ${ }^{61}$ These letters and articles have affirmed my discovery of quite unpleasant material, dealt with tactfully by Gee in The Fire-Raiser and The Fat Man.

In her article "Dickensian Grotesque in Maurice Gee's The Fat Man" Gloryroad Topham takes a refreshingly different approach, confirming the influence of Gee's reading on his work. ${ }^{62}$ Writing in Education in 1975 Gee himself acknowledged that Zane Grey's westerns enabled him to take his first look at "the human condition", and the subsequent influence on him of Dickens. ${ }^{63}$ My own article "A Straight Steal" examines the influence of Frank Sargeson's "An Affair of the Heart" on Gee's The Fat Man. ${ }^{64}$ 
Writing about octogenarians in Plumb and Prowlers, Leslie Monkman emphasises the antitheses and symmetries in Gee's adult novels. ${ }^{65}$ In "Human Cruelty Explored" Brenda Stone, studying The Fat Man in a secondary school context, suggests that patterning exists in the junior fiction as well, as does Jeannine Leibowitz's dissertation, Shaping Fantasies: A Comparative Study of Three New Zealand Children's Authors, which comments insightfully on the $O$ trilogy's divided worlds. ${ }^{66}$ Kathryn Walls' seminar paper “Maurice Gee's Debt to 'Double Unit': The Influence of Lyndahl Gee's Short Story on The Halfmen of O" was partially published in New Zealand Books. ${ }^{67}$ By showing that the division of humanity into "halves" in the $O$ trilogy was anticipated in Gee's mother's short story "Double Unit", Walls has provided a further suggestive context for my exploration of antitheses in the junior fiction. (Comparing Lyndahl Chapple Gee's Mibi and the Last of the Moas (1943) with Gee's $O$ trilogy and The Champion, Walls establishes crucial stylistic similarities between them, thus confirming the influence of external texts on Gee's writing.) Gee has described his interest in patterns of division, history, class and "a range of other us-and-them factors" to David Larsen. He has referred to the "union/non-union split of the 1951 waterfront strike, the backdrop to Orchard Street", and the Hutt Valley of Hostel Girl with its right and wrong sides of the track. He also acknowledges that his first ten children's novels are "split neatly down the middle: five fantasies followed by five historical thrillers". ${ }^{68}$ These points certainly affirm Gee's fascination with division and wholeness in his junior novels.

Material on the genre of the historical novel has assisted my analysis of Gee's realistic novels. As previously noted, Nathan Uglow in "Historical Novel (British)" explores the genre as hybrid, and its confusions of public and domestic, psychology and history, and fact and melodrama. ${ }^{69}$ Specifically addressing literature for younger people, Joanne Brown considers truth, balance and accuracy in "Historical Fiction or Fictionalized History? Problems for Writers of Historical Novels for Young Adults". ${ }^{0}$ In "Children's Historical Fiction: A Personal Assessment", Belinda Copson claims that in historical fiction, history may be integral to characters' development. ${ }^{71}$ Uglow, Brown and Copson have been especially helpful in exploring Gee's fusion of historical reality with the individual, imaginative and universal.

Addressing children's literature and critical theory, Maria Nikolajeva's Children's Literature Comes of Age: Toward a New Aesthetic provides invaluable comment on the realistic narrative; the first person, retrospective, older narrator; illusions of authenticity; and, in metafiction, on the text's own existence, and use of certain words and expressions. Gee's realistic novels display many of these features. Furthermore, Nikolajeva's discussion of the dialogue between primary and external texts, myth as 
intertext, and the presence of allusions and quotations based on adult codes has encouraged my examination of intertextuality in the realistic fiction. ${ }^{72}$ Mark Williams, writing in Leaving the Highway (1990), seems to observe in Gee's junior fiction features emphasised by Nikolajeva. The books for children, he claims, delight in lexical play. Williams makes the acute observation that the junior fiction accommodates the shift from realist and humanist narrative methods used in Gee's earlier adult fiction ending with Sole Survivor, towards (but not embracing) postmodernism in the later adults' fiction starting with Prowlers. ${ }^{73}$ His comments have extended my insights into Gee's almost selfreflexive style, and the apparent delight that he takes in writing supposedly simple material for children.

Peter Hunt's Criticism, Theory, and Children's Literature defines children's literature, and examines the author's moral obligation to write a book suitable for younger readers, and the consequent degree to which he/she governs possibilities of interpretation. Considering the author's need to exercise a control that may result, first in messages being omitted, simplified and stated; or second in messages that are suggested, indirect and oblique, Hunt examines related ways of reading. These include the mechanical, decoded, and denoted; and also the connoted, intertextual, and generic. ${ }^{74}$ Since Gee fuses an adult awareness of reality's unpleasant truths with writing material suitable for children, much in his books certainly conforms to Hunt's second levels of writing and interpretation. Elizabeth Hale's excellent paper "Representation and Responsibility in Under the Mountain", which examines the roles of child protagonists in saving or destroying lives, also deals with the adult issues which child protagonists in Gee's junior fiction face, and the difficulty of presenting them in an appropriate way. ${ }^{75}$

Roderick McGillis's The Nimble Reader: Literary Theory and Children's Literature (1996) further explores the application of literary theory to children's books. ${ }^{76}$ His coverage of a range of theoretical approaches, including historicism, reception, psychoanalytical, new criticism, and archetypal (to name but a few) has influenced my interpretation of Gee's books. Given the emphasis on history and childhood in Gee's writing, Gee's interest in literature, language and word play, and his pursuit of an organic wholeness, my approach to the junior works is historicist and to some extent biographical and new critical.

Although a collection of writings on Maurice Gee's fiction for adults and children (edited by Elizabeth Hale and Lawrence Jones) is forthcoming, there are no books solely devoted to the children's novels, and much of the aforementioned literature on them is brief. My thesis seeks to fill the gap in critical material on the junior fiction of Maurice Gee, considered by many to be New Zealand's greatest writer. 


\section{CHAPTER 2}

\section{The $O$ Trilogy}

\section{Introduction}

In Gee's fantasy novels for children an ideology of wholeness and balance is clearly spelt out. In particular, The Halfmen of $O$, The Priests of Ferris, and Motherstone (the $O$ trilogy) have as their main theme the quest for unity. It is the task of Susan, the novels' child protagonist, to restore balance to the planet of $\mathrm{O}$ by bringing together the separate sides of the Motherstone. Split in half by Otis Claw, a clever but duplicitous pupil of the sage Freeman Wells, the mandala-like Motherstone is Gee's most explicit image of balance. Indeed, as noted in the thesis's introduction, it strongly resembles the Daoist Yin Yang symbol, which represents life's antitheses united in harmony. When the image of the Motherstone first appears in chapter five of The Halfmen of $O$, it is referred to by Marna (Freeman Wells' wife) as "the Balance" (p. 69). ${ }^{1}$ Marna describes its original form before being split, and its replication in the birthmark on Susan's wrist. It has contrasting, but equally matched, interrelated parts, each of which is interdependent and integral to the definition and existence of the other and the whole:

\footnotetext{
Freeman, Firstman, made the Motherstone, and laid the Halves on it, and put Humankind in balance. Chaos stopped. History began. And Humankind lived for many thousands of years free to choose the evil or the good. Alas, there have been countless evil times, vile ambitions dressed up in great names. War and oppression stain the centuries. But the Balance held. The Halves lay on the Motherstone and Humankind stayed in tune with Freeman's Law. Light and dark contended and held each other in a deep embrace. Yes Susan, that is it, you have the mark on you. There on your wrist. See how the light bends into the dark, see how dark leans into light. They hold each other, good and evil. And see, if you look close, in the light there is a spot of dark, and in the dark there is a spot of light. (p. 69)
}

\section{Symmetrical Worlds}

Gee's concern with symmetry and balance is apparent from the outset of the $O$ trilogy. The Halfmen of $O$ starts by establishing antitheses. There are the different worlds of realism (ordinary rural New Zealand) which is where the novel begins, and fantasy (the planet of $\mathrm{O}$ ) in which most of the novel is set. But, as Jeannine Leibowitz has pointed out, these worlds are mirror images of each other and, like the Motherstone's interrelated parts, each bears traits that characterise the other. ${ }^{2}$ The real world's largely unspoiled countryside includes images of pollution in the creek's brown cloudy water and the hideous noise of gold prospecting. Such pollution strongly characterises $\mathrm{O}$ which, under the Halfmen, has become smoke-filled, reeking, barren and violent. The 
novel's real world also has in Susan a character inclined to reverie and dream. Conversely, the dreamlike, mainly corrupt world of $O$ includes the unspoiled woodlands, and human and humanoid characters thus recalling rural New Zealand and its inhabitants. Each of the opposed but contiguous worlds is therefore a microcosm of the whole, and each must find its own unity for the wholeness of the macrocosm to occur.

As a microcosm of the whole, $\mathrm{O}$ has a weight or solidity that comes from history and from particular, cultural and universal dimensions (previously introduced). Because it is a fantasy world rather than a realistic world, the particular is less obvious. Links to personal detail and people from Gee's own life may be confined mainly to the woodland settings which recall Nelson (where Gee lived), and to the resemblance of Susan to Gee's daughters or Gee himself as a reflective author. A further connection might exist between the Halfmen's palace, described in The Halfmen of $O$ as a "giant beehive, buried in earth" and marked by "busyness [ . . ] , ceaseless humming, and guards darting angrily, like soldier bees" (p. 169) and Wellington's seat of parliament, commonly called "the beehive". Furthermore, Otis Claw (inhabitant of the palace's central "Pit"), with his bald head, obesity, eyes like "little black marbles", and manipulative personality (p. 170), recalls the similarly-featured Robert Muldoon, Prime Minister of New Zealand in 1982 when The Halfmen of $O$ was written. ${ }^{3}$

Cultural analogies, including political history, are more overt. In mirroring the fictional real world (which in turn mirrors the non-fictional real world) O confronts Susan with versions of its beliefs and wars, all of which fuse. For example, The Halfmen of $O$, Priests of Ferris and Motherstone are allegories of world wars - possibly World War I, World War II, and the Cold War respectively. This seems obvious in that each novel depicts a dictatorship and totalitarian regime, and includes symbols with political connotations. In The Priests of Ferris the black outstretched eagle wings (emblematic of the priests' evil Ferris religion) recall Nazi Germany's coat of arms (p. 102). ${ }^{4}$ And in Motherstone Osro's and Widd's "Weapon" which can "burn trees and melt stone" (p. 56) recalls the nuclear weaponry of the Cold War. ${ }^{5}$

But $\mathrm{O}$ is also a universal mythical world or, as Nick says in chapter four of The Halfmen of $\mathrm{O}$, a "sort of alternative world [in which] the moon is different, and the stars" (p. 56). Indeed, in $\mathrm{O}$ as a fallen Eden, encounters with death and corruption seem necessary for redemption and a return to innocence. In travelling through $\mathrm{O}$, therefore, Susan explores a dream world and effectively the whole collective psyche, as is suggested by Gee again in terms of quarternities. O has four nations: the hotlands in the north, Darkland in the south, Morninghall in the east and Wildwood in the west (p. 
104). Susan also experiences historical wars, suggested by analogies between O's characters and ancient cultures and tribes. The Halfmen are compared to Roman soldiers, Osro and his troops to Tartar and Mongol warriors, Widd and his Freemen to America's early settlers, and the Stonemen and Soona to Tibetans and Chinese. Parallels between O's animal folk and warrior tribes evoke ancient times. Redwing, Yellowclaw and the Birdfolk are comparable to American Indians, the Vargs recall the Russian bear, the Woodlanders recall rural dwellers of olde England, and the Stonemen Germany's Aryan tribes. But Gee fuses the historical with the elemental - the Birdfolk are associated with air, Seafolk with water, Woodlanders with earth, and the bloodcat with fire.

Through befriending these creatures Susan thus explores the elements which in turn seem emblematic of the psyche. When she flies she experiences the air at O's heights and the Birdfolks' pride, and in descending through an anthropomorphic landscape's "throat of the underworld" (p. 124) she enters the earth's bowels to witness the Stonefolks' humility. Here individuality and indeed life are virtually non-existent whilst the mud at the bottom can be paralleled to the lifeless matter that may exist at the most primordial level.

\section{Characterisation}

Although connected to both the novel's real and fantasy worlds and to its historical dimensions, characters individually are not complex, but rather are opposed types that collectively represent a whole. Those from the fictional real world are human and those in $\mathrm{O}$ are fantasy, but both sets of characters can be further divided. Taking the "real" characters first: Susan is introverted, inactive and dreamy and, as noted in The Halfmen of $O$ 's first chapter, is "not in the real world" (p. 18) whilst Nick is extroverted, active and intelligent, and follows Jimmy Jaspers' advice in Motherstone to “use yer loaf” (p. 28). O's fantasy characters can be similarly divided. Marna, who is the forerunner to Susan as the chosen one, is gentle and has natural wisdom and foresight, whilst the Halfmen are fleshy, cunning, strong- willed, and brutal. And Soona (daughter of Kenno, chief of the Freemen tribe and the future chosen one) is sweet-tempered, kind and musical, whilst Aenlocht (a boy from the Hotlander tribe) is hot-tempered, active and physical. O's characters are therefore more extreme versions of Susan and Nick.

But in a further contrast Gee shows real humans to be, if not complex, then at least mixed (or "Mixies") and characters in $\mathrm{O}$ to be one-dimensional. As Mixies humans are either good with an element of evil, like Susan and Nick, or evil with an element of good, 
like Jimmy Jaspers and they have some choice over their fate. On the other hand, characters on $\mathrm{O}$ are either good or bad, have little choice, and are one dimensional. They are of two main types, each of which can be further divided. First, the Halfies are humans, including those who are completely good like Marna and Freeman Wells, and those who are completely evil like the Halfmen or Priests. Second, the creatures of nature are either good like the Woodlanders, Stonefolk, Waterfolk, and Birdfolk, or evil like the bloodcat. However, even these groups can be broken down. For example, the Woodlanders include Brand (suggesting fire) and Verna (Latin for Spring); the Stonefolk comprise Seeker and Finder, the Waterfolk include the Varg and the seal, and the Birdfolk include Redwing and Yellowclaw. Cross-contrasts also occur. The Halfmen, although human, look and behave like wild animals and include dictator Otis Claw, and servant Odo Cling. Conversely, the Woodlanders, although animal, look and behave like humans, and include Brand who commands and Verna who obeys. Through creating such a diversity of characters Gee suggests not only division but also the possibility of balance and the whole.

Even amongst O's more one-dimensional creatures there are instances of reversal and balance. In Motherstone the bloodcat, once tamed by Susan, becomes her ally, Aenlocht leaves the aggressive Hotlanders to participate in Susan's quest, the active Nick indulges in reverie (p. 54), and the reflective Susan becomes more active. In The Priests of Ferris the proud Birdfolk, by crawling through stone and mud, find the worm within them and thus learn humility. Although characters are different, then, there is much about them that is the same, and it is through recognising commonality that they communicate and find balance. Such is not the case with the Priests of Ferris and the initially proud Birdfolk, both of whom are associated with the eagle - the national symbol not only of Nazi Germany but also of America. However, although previously opposed, the bluewhite Varg and the red and gold Birdfolk in The Priests of Ferris are on the same side and are equal:

The Birdfolk and the Varg faced each other in the thin morning light. Yellowclaw stepped forward slowly. He spread his wings a little, held them forward, a movement that seemed to enclose Ben. The bear rose on his hind legs. They were equal in height; and equal in every way, in strength, in authority even, though each was different in colour.

Dawn whispered, [... ] 'In olden times they were enemies. Now they are friends'. (p. 156) 


\title{
Susan and her Quest
}

As a "Mixie" Susan must still operate as an individual as only she has the knowledge and power to restore the Motherstone's separated Halves. Gee seems to emphasise the importance of self-knowledge in the undertaking of such a difficult task and, indeed, Susan's very experiences on $\mathrm{O}$ require her to confront herself. In seeking the whole Motherstone, Susan must pass through stone - a process that almost destroys her. In fact, in travelling between opposed worlds, she (and Nick along with her) must be physiologically broken down and then restored to wholeness. As Nick tells Susan in chapter four of The Halfmen of $O$, "When you sniff [Jimmy Jasper's bottle of smoke] it drags you in. Then it breaks you down somehow, into molecules maybe, or impulses, and you go through a warp. It puts you together again when you come out the other side" (p. 56). Susan's descent from the real world, down the mineshaft, and up into $O$ is therefore a compressed journey through the elements, almost to die, and then to be reborn. This physical journey, and indeed Susan's journey through $O$, may be a metaphor for the archetypal journey through the psyche, as we see in chapter three of The Halfmen of $O$ :

\begin{abstract}
It was like being sucked into a dream of red lights streaming in water; then of going deeper, until the light was water, all colour gone, until water was mud, jet black, and mud had turned to earth and earth to stone, and stone was everything, stone was the world and life, stone was air, stone was past and future, stone was the screaming sound she tried to make. And then - before that last tiny consciousness faded away (and she held on to it desperately, for it was all she had) - the whole process went into reverse, there was a painful climbing back, through stone, through earth, through mud, through light and water. It was like being born. It was terrible, and glorious, coming back to life. Red lights streamed again, spinning like whirlpools. The sucking was reversed. She was being thrust up, she was spinning up the walls of a giant funnel into the world after being sucked hungrily into the stomach of death. She screamed with relief. (p. 33)
\end{abstract}

Against this terrifying journey through chaos, Gee sets the positive experience of sniffing Shy. An image of symmetry, Shy lacks the solidity and wholeness of the symmetrical Motherstone. Nevertheless, after Susan's journey through stone to O, it fully restores her sight. A modest and unassuming wild plant - "a plain little grey flower [that is] shaped like a snowdrop" (p. 59) - it has tremendous power. Emblematic of the creative imagination, it provides a crucial corrective to the depressed grey world as $\mathrm{O}$ appears to Susan. When she inhales its scent in The Halfmen of $O$, her senses are heightened and her view is joyous:

With an uncertain smile, she lifted the flower to her nose and breathed in. For a moment nothing happened, she smelt nothing. Then something seemed to break in the flower. A waft of perfume rose about her face. It was cold as snow and delicate as a breeze, sweet yet astringent, like lemon blossom. It raced through her quick as water, reaching through her brain and through her body. It set everything singing and 
vibrating. The world in front of her sprang out like a darkened room when the light goes on. Susan gave a cry of wonder and delight. Wildwood stood before her in its colours. The sun rolled yellow in the sky. The trees were like green and golden cities. Bright birds fluttered in their upper levels. The stream was transparent blue, the grass was green, and berries bright as lipstick clustered on the bushes. She looked at her palm - her own pink palm - and the Shy lay there, bright blue as the sky. (pp. 59-60)

Significantly, in The Priests of Ferris Susan's second journey to O is effected by Shy, this time blossoming in the novel's real world from a seed that she has earlier planted. Here the plant's connection to art and writing is explicit. Indeed, so beautiful is Shy's perfect symmetry that it moves Susan to worship and accompanies her intuitive knowledge of the presence of Limpy (a messenger whose task is to take Susan to Soona):

\begin{abstract}
She saw the Shy at once, a silver plant growing no higher than a daphne bush, with a dozen blue flowers just visible in its leaves. It was rather stiff, she thought, a bit like a pen and ink bush, a formal drawing at a chapter head, and for a moment she was disappointed. She had hoped for something that climbed down rocks and grew in crevices. Then she saw its symmetry, its silver leaves and magic flower, and it overcame her. She dropped on her knees to worship it, and almost as if she had expected him she saw the boy in the deepest shade, kneeling in the same attitude. (p. 10)
\end{abstract}

Shy, then, plays a part in Susan's personal balance, and in her tripartite progression from wholeness, to disintegration, to wholeness. This progression is repeated throughout the $O$ trilogy, and seemingly suggests that division and knowledge of mortality are essential to creativity and wholeness. In chapter eight of The Halfmen of $O$ Susan describes to Nick how she felt when first she picked up the Motherstone's good Half which represents "half of everybody in the world" (p. 111): "I thought I was going to break into little pieces. Something went right through me. It was like electricity. I felt every part of me - my heart and my muscles and bones. My eyeballs and teeth and toenails. It was horrible. They all separated. And then, somehow, they all came back together. But I felt I was different. I was changed. Something was added to me” (p. 110).

What is new, as we discover in chapter nine of the novel, is self-awareness through feeling, hearing and seeing separate parts. Upon descending through "the Throat of the Underworld" (p. 124) - a process whereby physical balance ensures the effective penetration of stone - Susan experiences the evil within the Motherstone's evil Half and in effect within herself:

She felt herself spinning as if in that whirlpool between the worlds, and parts of her, brain, tongue, heart, bowels, went whirling away, each crying on its own in a dreadful agony. [...] She heard herself scream. She heard herself. And that was the good Half's doing. The good Half was holding her together, the good Half was showing her herself. She screamed again. She screamed as a message to Susan Ferris. [ . . ] And slowly, slowly, with infinite pain, she came back together, all her whirling parts swam into place and fitted in, and she was whole. (p. 135) 
As Watcher (the creature who guards the Half) says, "The evil in [the Half] sprang to life and tried to destroy you, as it has tried to destroy me. But it can do no harm now. You have drawn it into balance" (p. 135). Susan's experience of division as essential to wholeness recalls the experiences of Gee's adult characters - Plumb, Raymond Sole, and Noel Papps are all concerned with examining parts, before piecing them together and understanding the whole. As previously noted, Gee's very creation of characters in the $O$ Trilogy involves breaking them into sub-divisible parts. In a process not dissimilar to the acts of thinking, writing and chemistry by Plumb, Raymond Sole, and Noel Papps, Susan as an individual must be destroyed, then made whole, before she can create wholeness and balance in $\mathrm{O}$.

Susan's role as an individual fuses with her emblematic role, and it is the latter role that contributes to stillness. Such roles can be seen in terms of archetypes. Freeman Wells, for example, represents wisdom but, dead before the first novel begins, he is replaced by the cunning Jimmy Jaspers. Most obviously, Susan as the chosen one resembles the archetypal hero. Indeed, as saviour, Susan must rescue $O$ from evil and effectively bear others' sins in that the priests, having appropriated her name, project their evil Ferris religion onto her. In Marna, Susan encounters a figure of wisdom whose knowledge and stories she absorbs. ${ }^{6}$ Then to Soona (whose name conflates solar and lunar) as the one who will take Susan's place, Susan becomes the wise one that Marna once was to her. Susan, then, is a composite of youth and maturity, and of innocence and wisdom. Although a mixed individual subject to change, she is also as a symbol of good, tranquil and still.

However, in $\mathrm{O}$ wholeness cannot be achieved by Susan alone, or as one of an opposed pair, but must involve a quarternity and trinity. Thus in Motherstone, by some natural law, the bloodcat joins with Susan, Soona, and Aenlocht to form a foursome that allows for the formation of the whole. Not only is the bloodcat (bestial, amoral and wild) the antithesis of Susan (human, moral, and civilised), it also contributes to the “cell" (p. 164) or "knot" (p. 169) that is completed by the opposed Soona and Aenlocht. As a set of two paired opposites the four therefore represent a microcosm of the whole and can be compared to the quadrangle that forms an essential part of the mandala.

Eventually, though, the bloodcat, after fulfilling its role, falls away and it is left to the triad of Susan, Soona and Aenlocht to bring about wholeness. That the $O$ books form a trilogy suggests that, indeed, three are needed for wholeness to occur. Recalling the Plumb trilogy and its one hundred-year timeframe, each of the $O$ trilogy's books covers a one-hundred-year cycle of "turns" and is whole in itself whilst contributing to the larger whole of the three. In chapter six of Motherstone Gee explains the part played 
by three in making a whole: "[Susan] knew her bond with $\mathrm{O}$ was a special one. Twice she had been called, and somehow not completed her task. Now it seemed three was the special number. Three would make things whole" (p. 85). Significantly it is three humans - Susan, Nick, and Jimmy - who travel between the opposed worlds of reality and fantasy, and in the trilogy's third novel it is three humans - Susan, Soona, and Aenlocht - who finally restore balance to O. As Jung has explained, the mandala's final circular shape emerges from a triangle set in a square. ${ }^{7}$ And Adele Nozedar, discussing the symbolism of number, refers to the frequency with which trinities occur in Christianity, eastern religions, and myth, and considers three to be a satisfying and perfect number involved in the "completion of a cycle". "Thus Gee emphasises a numerological significance to the composition of the Motherstone itself and the $O$ trilogy.

\section{The Organic Structures of Language and Image}

Like Gee's fiction for adults, the $O$ trilogy uses myth, symbol and other poetic devices to depict an imaginative truth that is part of the whole. In the $O$ books the real and the imagined, like Raymond Sole's two worlds, are interchangeable with each underpinning the other. For example, in chapter three of The Halfmen of $O$ Susan sees the mountains figuratively as religious figures: "Beyond were hills, stretching along the horizon, and mountains with grey snow on them, standing steep and tall, like a file of monks in shapeless habits" (p. 35). Shortly after when she meets Odo Cling's Deathguard the impression, whilst remaining a simile, takes a human form: "All about the tongue of stone silent men were standing. They had come without a sound. They were dressed in black robes, like monks, and had black hoods on their heads" (p. 36). And in The Priests of Ferris the premonition is fully realised in the priests with their hoods and rosaries of bones. Compared by Gee to swamp beasts, the Halfmen and Priests seem to be emanations from a shadowy inner world that has been seen by the intuitive Susan even before becoming manifest. We must not therefore trust Jimmy Jasper's description in Motherstone of old tales in songs (and by implication poetic language) as "rhymer's nonsense" (p. 49), but should instead read figurative language as suggesting a possible future reality.

Figurative language thus contributes to the depiction of a potentially whole world which Susan sees intuitively. That Susan communicates with O's creatures and characters - the Vargs, bloodcat, Soona and Aenlocht - through the imagination, by making mind pictures, suggests her attunement with a mythical pre-conscious, prelinguistic world. Like Ellie, whose best paintings include image, myth or symbol 
experienced from "a kind of deep acquaintance" (p. 307), Susan creates pictures in which, on a deeply intuitive level, she becomes fused with the inhabitants, politics, myths and nature of the mythical world of $\mathrm{O}$.

In Private Myths: Dreams and Dreaming Anthony Stevens has suggested that figures of speech, and indeed poetry, are the language of imagination, myth, dream and the unconscious mind, and express images that are archetypal. Metre, he claims, originates in ancient ritual and primordial nature with a "metric pulse" common to all languages. Stevens distinguishes between two primary modes of speech - the metomymic statement and metaphoric association. In a metonymic statement words form linear sequences of phrases and sentences, and convey the literal. Stevens parallels metonymic statements to the rational, the logical, and the ego's syntax. Gee uses plenty of these. In a metaphoric association, words are linked by shared radical elements, analogy, and similar sound images. Stevens parallels these associations to the irrational, mythical, soul, and dreams, with multiple interpretations. He notes that their deepest meanings may not lie in lexical, syntactical or etymological associations but in associations that are phonemic, imagistic, and archetypal. ${ }^{9}$

In the $O$ trilogy many such metaphorical associations occur. For example, the phonetically affiliated names Odo, Otis, Osro, and O, share the sound image of "O", and the nouns Susan, Soona, and Slarda share the sound image of "S". The "O" phoneme suggests archetypes of wholeness or conversely nothingness, whilst the "S" phoneme suggests archetypes of mediation, or conversely the serpentine or divisive.

Interestingly these particular phonetic associations also operate as visual images. Taking the "O" and the "S" we see that both images contribute pictorially and phonetically to the word "Motherstone," and also, with its circular frame and central bending "S", to the Motherstone's very appearance and shape. Gee emphasises the Motherstone's specific features in a number of places. In chapter twelve of The Halfmen of $O$ when Susan re-unites its halves, "a tiny thread of light [runs] round them in a circle, through them in an S, fusing them in the Stone and to each other" (pp. 179-180). And in chapter eleven of Motherstone, the Halves are "fused in the rock, making a circle, red in one part, gold in the other. [Susan lays] two fingertips on the Halves, and [sees] the thread of light run round the edge, and through the S dividing them" (p. 177).

The Motherstone - a mandala-like image of totality - therefore evolves organically out of the story and the fusing of characters' minds and lives, especially those of O's folk with Susan. This fusion is anticipated by some of the novel's characters. In chapter seven of Motherstone Watcher comments that Susan Ferris seemed "woven into the history of O" (p. 107). Nick also thinks of her as "woven into O" and 
"like a figure in a tapestry, from another time" (p. 108), whilst Jimmy and Susan herself compare her integration with $\mathrm{O}$ to being woven into a tapestry or into a book (p. 147).

Indeed, as noted previously, Susan has entered into all parts of $O$, having travelled north, south, east and west, flown in its skies, and descended through stone into its earth. During her adventures Susan has taken $\mathrm{O}$ into her, having eaten its fruit, sipped and given her name to its waters, seen its sights, and sniffed its Shy. ${ }^{10}$ As the phonetic "oo" central to her name confirms, $\mathrm{O}$ is as much part of her as she is of it. Something similar can be said about Soona who, in sharing assonance and consonance with Susan, is as interwoven with her as she is with O. In chapter eight of Motherstone Susan realises: "Their minds had joined, had woven round each other like two vines" (p. 114). When Aenlocht enters her mind's pictures, he and Susan also become interwoven. Embodying not only O's antitheses, but also by implication everything that is in between, Soona and Aenlocht represent the Motherstone's opposed light and dark Halves that, with Susan's help, become fused and alive. Together with Susan as mediator, each is therefore essential to the whole, as is suggested in the symmetry of their approach to the Stone when the three fall naturally into the pattern of "the Knower, with the Pale One and the Red One flanking her" (p. 167). Standing between Soona and Aenlocht, Susan is a central binding force, just as it is the " $\mathrm{S}$ " of her name that fuses the halves of the stone together to complete the progression from duality, to quadrangle, to triangle, to the circular mandala-like whole. Again, then, Gee reveals an interest in the visual imagery of letters, and in numerology, and their function as symbols that contribute to the idea of wholeness.

\section{Conclusion}

Susan's central position between Soona and Aenlocht, between O's warring forces and diverse folks, and between the Motherstone's two halves, resembles the position of the ego that must mediate between the psyche's warring sides and hold microcosm and macrocosm still, as described by Jungian critic, D. Stephenson Bond:

\footnotetext{
Thesis and antithesis wrestle in unending conflict until a synthesis emerges. In psychological terms, if the tension of the opposites is held long enough - that is, if the ego does not identify with one side or the other, but remains suspended between the two, holding the tension - it allows for the appearance of the transcendent function, which is essentially a symbol that unites, or includes, warring opposites. In effect, consciousness is raised to another [higher] level that is able to integrate the opposites as a unity. ${ }^{11}$
}

This is exactly what Susan does in maintaining the tension between the opposed Vargs and Birdfolk; Osro and his troops, and Widd and the Freemen; and even Nick, Jimmy, 
Limpy, and Aenlocht. Most importantly, she unites Soona and Aenlocht and restores balance to $\mathrm{O}$. In effect, therefore, she is balancing the psyche's positive and negative sides. It is her ability to remain central yet detached that leads to a higher state of grace, and it is out of this that the Motherstone as a symbol of totality evolves.

Susan's position within the Motherstone is comparable to the mandala's central point, and also recalls the author's proclaimed placement of himself within the whole novel's still centre. Thus Susan resembles the creative author, Gee himself, whilst the Motherstone may be seen as a metaphor for the fictive process, and a measure of the degree to which Gee achieves balance and wholeness in the five historical novels for children. 


\section{CHAPTER 3}

\section{The Fire-Raiser}

\section{Introduction}

That The Fire-Raiser is set in a world divided by war allows Gee to consider opposed political forces - Great Britain and the Allies on one side, and Germany and the Central Powers on the other. As noted in the previous two chapters, Gee's concept of balance requires a concept of parts involving the historical dimensions of particular, cultural, and universal. This and each of the following chapters on Gee's historical novels progress through these broad historical dimensions, and from recent to ancient times.

\section{The Nelson Central School Material and F.G. Gibbs}

In forming historically realistic worlds Gee turns, as he has in his books for adults, to the lives of himself, relations and acquaintances, and to social history, to recreate much that is authentic and real. Indeed, The Fire-Raiser is recognizably located in Nelson in 1915 - characters replicate Nelson's historical figures, and explicit reference is made to real events. Gee actually discovered much of the novel's material in the course of research he undertook to write his only non-fictional text - Nelson Central School: $A$ History.

The school history came about partly because in 1975 Gee shifted to Nelson with his wife Margaretha, and young family. While Margaretha was employed as librarian at the Nelson Provincial Museum and as a part-time archivist at the Cawthron Institute, Gee cared for their two daughters. He supervised their leisure activity when they came home from Nelson Central School, and during school hours was free to write, completing over this period several novels for children and adults, including The FireRaiser in 1986.

Most significantly, Gee also completed a history of his daughters' school in time for its centennial celebrations in 1978. Two newspapers (The Colonist and The Nelson Evening Mail) and memories of the school's ex-pupils provided sources of information for the history which also drew on the Nelson Provincial Museum's archival material, particularly the diaries of F. G. Gibbs, headmaster of Nelson Central School from 1894 to 1923. Shonadh Mann's biography of Gibbs, F. G. Gibbs: His Influence on the Social History of Nelson, 1890 to 1950, was another important source. ' It too drew on Gibbs' diaries, interviews and memories. Nelson Central School: A History has been rightly 
described as unusually vivid and "a major contribution to the history of education based on extensive oral research and Gee's sensitivity to social issues". 2

However, Nelson Central School is much more than a bare recitation of facts. Instead it shows Gee's interest in a whole truth, especially that related to lived experiences in Nelson between 1878 and 1978. Including the memories of Gibbs and other past teachers and pupils - their voices, stories, playground rhymes, thoughts, feelings, and recall of daily events - Gee recreates school life as it might be represented in a novel. Responding to the nostalgia of his sources, Gee shows the past in a rosy light, but he also shows the darker side of things. The reader therefore has access to the fun and discomfort of social gatherings, the affection and fear felt by pupils for their teachers, the kindness and cruelty of some teachers, individual compassion and mob prejudice, and the times of nationalist uncertainty yet patriotic complacency.

The school inspectors captured in Nelson Central School are on one level sympathetic to John Dewey's progressive model of teaching, and encourage experiential child-centred learning, but on another level conform to the traditional British model with its rote learning and corporal punishment. As Gee records it, W. C. Hodgson, Inspector of Schools for the Nelson Education Board from 1863 to 1893, typified the period's ambivalence. A believer in schools as "humanizing agencies", Hodgson expressed concern at the popularity of arithmetic, a subject he believed made "fewer demands upon the imagination [ . . ] turning out hundreds of young Gradgrinds, with a turn for nothing but 'hard facts". Hodgson also had the "disturbing opinion" that military drill "helped bring up a 'readily obedient race". 3 Similarly two-sided is Gee's picture of the schoolteacher Miss M. Kitching. Remembered by past pupils as "a dear soul, but very stern" (p. 50) and as "loved and respected", she is differently described by one pupil in a playground rhyme:

Kitch, Kitch, the silly old bitch, Goes to church on Sunday, To pray to God To give her strength To whack the boys on Monday. (p. 51)

In Nelson Central School, then, Gee paints an ambiguous picture that is testimony to his willingness to grapple with the mixed nature of truth. He pays heed to the school history's literal side - basic units of dates and facts - but also to its subjective dimension which incorporates falsification and discernment. Of all the material used to such effect by Gee, none reveals so much about the times or the individual recording them as F. G. Gibbs' diaries. It is illuminating to examine Gee's treatment of these. 
Although the Nelson Central School story is tracked from 1878 to 1978, the section devoted to the Gibbs period is longer and more vivid than any other. Gee notes in the Introduction, this is partly because "the memories of older ex-pupils [...] were detailed and vivid" (p. 7). Within the section on the Gibbs period, it is the headmaster, F. G. Gibbs who (alive in the memories of those who had known him) is most vividly depicted. Gee records many facts about Gibbs. In 1887 Gibbs taught briefly at Bridge Street School. When he left at the end of the year the boys gave him a thermometer as a leaving present. From 1894 to 1923 Gibbs taught at Nelson Central School, gaining the reputation of being forward-thinking and knowledgeable. He established a cricket club, planted trees on Arbor Days in 1899 and 1900, and took the children on class trips.

Gibbs also comes across as a liberal humanist, with wide-ranging interests across the arts, humanities, and sciences. Recalled as a philanthropist, and intensely ideological on behalf of "mankind", he seems to have had a larger-than-life personality. Gee records, for example, that Gibbs was fervently anti-jingoist and well known locally for defending a German music teacher against racist attacks during World War I. He describes Gibbs' subsequent reputation of being pro-German, unfair castigations of him as "a dirty German Jew" and "German Sausage" and the resulting nickname "Sos" (p. 49). Past pupils, their memories often quoted verbatim by Gee, speak glowingly of Gibbs, describing him as "an outstanding teacher and headmaster" (p. 5), "a Renaissance man" (p. 95), and "a rotund little man, thick-set and bursting with energy" (p. 49).

Within the recitation of fact and memory Gee includes the human element. In the section entitled "The Gibbs Years, 1894 - 1923" he provides descriptions of Gibbs' numerous idiosyncrasies. Citing the Mann biography, Gee notes "the attractive picture of the headmaster walking in the playground followed by a trail of children chanting their tables and spelling at him" who became known as "Gibbs' Puppy Dogs". He quotes the account of a Mr J. Grigg (ex-pupil and later teacher) of how Gibbs, performing a "bell-ringing ritual", at 8.55 am would "sail along the front fence on his motor-cycle and the first boy to see him would race to ring the bell". Recording the recollections of Mr J. Savage (another ex-pupil and teacher), Gee notes the folding magnifying glass, thermometer, and tuning fork that Gibbs, a keen scientist, carried in the "innumerable pockets in his waistcoat". And Gee describes Gibbs' biology lessons on "the bones of the body", using a skeleton known as "a French lady": "[Gibbs] had obtained a skeleton said to be a French lady and this was kept in a cupboard and brought out for lessons. Later it was moved to the belfry. Gibbs would send a boy to fetch it when it was needed. From this the boys learned the bones of the body" (p. 43). 
However, Gee complicates the charming, affectionate picture of Gibbs. He comments in the preface: "In writing of earlier times I have described people connected with the school as historical persons, open to examination and criticism” (p. 7). The portrayal of Gibbs is accordingly interspersed with stringent criticisms, particularly apparent in Gee's selection of episodes revealing the headmaster's less appealing side. Depictions of Gibbs' various battles with the Town Schools Committee from 1896 to 1899 hint at Gibbs as cocky and aggressive, a picture painted by Gee through the inclusion of Gibbs' own words. According to Gibbs “a cheeky letter" (p. 39) was sent on one occasion to the Committee, and on another a "short but sweet reply", and upon winning a battle Gibbs vengefully said, "I had my innings" (p. 41).

Emphasising Gibbs' petty vindictiveness, Gee describes his involvement in a dispute over riparian rights to swimming holes on the Maitai River in 1916, and the ensuing court battle against landowners, a Mrs Richardson and her two daughters. Any sympathy for Gibbs is qualified by Gee's own considered opinion: "We must not think all the fault was on Mrs Richardson's side". Gee also quotes an ex-pupil's recollection of an incident involving the Richardsons' hydraulic ram: "I have seen Mr Gibbs deliberately stick little bits of wood or leaves into the flapper of the valve to jam the mechanism. He did it in front of the boys and thought it was clever. I thought it was a dirty thing to do" (p. 49).

Gee's abhorrence of Gibbs' nastiness is apparent in the attention given in the school history to Gibbs' battles with children. Gee enables the reader to see the irony of Gibbs' reference to a member of the Town Schools Committee as a "bully" and to his behaviour as "tyranny" (p. 41), whilst subjecting children to harsh corporal punishment. Quoting the diaries, Gee allows Gibbs to expose his brutality in his own words: "When Mr Worley was sick [Gibbs] took his boys - 'horrible young rogues' and took the infants - '40 brats' - when Miss Snart was sick. With Worley's boys he had to "use the stick a lot"' (p. 16). Gee further records: "Jickell gave me a cheeky answer [... ] so I took him in and thrashed him immediately. This has had a good effect on him and all the others" (p. 36).

By juxtaposing descriptions of amusing and brutal incidents, Gee emphasises Gibbs' lack of justice, humour, and self-awareness. He describes an ex-pupil's memories of spectators and fighters being strapped by Gibbs, the thrashing given to boys wrongly accused of kissing a girl, and the fact that "Gibbs could not see he had done anything wrong” (p. 50). A poem by another ex-pupil displays a clownish though militant side to Gibbs: 
Denne's Hole is a lovely place,

It gives much pleasure to every face.

When lessons are done, away we run

To swim and dive and have lots of fun,

And old Sos Gibbs in his neck-to-knees

Looks like a beer barrel standing at ease. (p. 49)

Gee notes that Gibbs "was not amused" by the poem and "took the boy in and strapped him so severely his hands were swollen for a week". Pronouncing Gibbs to be prone to "unjust punishments", Gee offers a balanced and qualified opinion: "Although most of his pupils remember him affectionately - 'a fine old character, with exaggerated qualities' - to others he was a 'dreadful little autocrat"' (p. 50).

In Nelson Central School Gee depicts subsequent years, other personalities, and the 1978 centennial, but it is Gibbs who remains in the reader's mind. Although much briefer than Mann's biography, Gee's history gives a more complicated view. Where Mann emphasised Gibbs' public persona, Gee depicted the private, less pleasant individual, and different perspectives, including his own, thus constructing a portrait of Gibbs that is satisfyingly rounded, authentic and whole.

\section{The Nelson Material and the Novel}

The complexity present in Nelson Central School in the rounded depiction of Gibbs is paralleled by Hedges in The Fire-Raiser, which actually draws on the school history as its artistic model, and uses it and related material as its sources. It is the grounding in sociohistorical reality that gives the novel much of its vitality and apparent truth. As Bill Manhire has noted, the novel's "setting is a town rather like Nelson early in the century - and the story, which centres on the activities of an arsonist, has its roots in material Gee uncovered when he took on the task of writing a history of Nelson Central School for its 1978 centennial celebrations". ${ }^{4}$ Gee has acknowledged these connections:

\footnotetext{
The idea for The Fire-Raiser began when I wrote a history of the local school and came across one of the early headmasters - an outstanding character in Nelson's history. Then there was a bricklayer who was a firebug. He claimed at his trial that he burnt down buildings to make work for the unemployed. So I had these two characters almost ready-made and mixed some children in with them to create the story. ${ }^{5}$
}

Nelson Central School was published in 1978. Some time later, as he has recently recalled, Gee was asked by Ginette McDonald to write a children's television serial. He wrote five scripts then quickly turned them into a novel which "came out at the same time as the television serial". ${ }^{6}$ Perhaps the forest fire in Nelson's Hira Forest and Maitai Valley in February 1981 further influenced Gee who has acknowledged seeing it at 
"close hand". 7 Possibly reminded of material uncovered in writing Nelson Central School, particularly Johann Blecher's fire-raising escapades in the nineteenth century, Gee may have recognized arson as a theme for a good story.

Blecher's arson was reported in Nelson newspapers between 1892 and 1894, and was recorded in a 1957 issue of Journal of the Nelson Historical Society in an article entitled "An Early Incident" by L. E. Baigent. Baigent noted observing the demolition of a brick building at 130 Rutherford Street, Nelson, and remembered its occupant of sixty-five years earlier "Blicker" (hereafter referred to as Blecher), a bricklayer and plasterer, and immigrant of German extraction. He recalled Blecher's fires and the damage they caused, and Blecher as "a very secretive, morose type", and commented: "Our master-bricklayer, over the years, became more and more a recluse; more and more morose; more and more difficult to approach without evoking tirades against the community in general". ${ }^{8}$

As Gee recorded in Nelson Central School, Blecher set light to several buildings in Nelson, including stables, a bakery, and schools. On one occasion police found stacked wood and sacking soaked in kerosene. The fires evidently sent their glare into the night sky, and were signalled by the fire bell. They were attended, sometimes unsuccessfully, by a valiant brigade. They caused much disruption, especially to the schools' staff and pupils who had to be relocated. Apparently unstable, Blecher believed himself to be trying to create work for the unemployed. When finally caught and arrested by a Constable McGrath, he was sentenced to imprisonment with hard labour.

Similarities between the fire-raising of Blecher/Blicker and Marwick in the novel are obvious, with Gee apparently basing his depiction of Marwick on Blecher. Like Blecher, Marwick is morose, reclusive, and aggressive, and burns stables and a bakery, and attempts to burn the school. He even uses materials similar to those reportedly used by Blecher - cotton waste and rags, a crowbar, and benzene carried in a sack. Recalling Blecher's fires, Marwick's fires light up the night sky, and are signaled by bells - the fire bell and the school bell. Like the historical fire brigade, the fictional fire brigade is not always able to control the fires, which cause much disruption. Recalling Blecher, Marwick is unbalanced. Where Blecher was led off to imprisonment by Sergeant McGrath, Marwick is led off, presumably to imprisonment, by Sergeant McCaa.

A further parallel exists between F. G. Gibbs, as described in the school history, and Thomas Hedges in The Fire-Raiser. Where Gibbs was teaching headmaster of Nelson Central School, Thomas Hedges is teaching headmaster of Jessop Main School. (Jessop is simply another name for Nelson - both towns feature lime trees, willows and a river.') 
Moreover, Gibbs and Hedges have in their schools barefoot, poorly clad children, some of whom belong to a gang called "Port Rats". Like Gibbs, Hedges is a bachelor.

From Nelson Central School we discover that Gibbs' wide-ranging interests across the arts, humanities and sciences carried over into his teaching. As Gee has commented, Gibbs was "a sort of marvellous headmaster, a man of so many parts that it is almost impossible to enumerate them. Gibbs was interested in everytbing". ${ }^{10}$ Similarly Hedges has interests in the arts, humanities, and sciences that inform his teaching and outlook on life. Furthermore, Gibbs taught informal lessons in the local observatory: "When the observatory opened in Alton Street the senior boys went over with Gibbs on the longest and shortest days and had informal talks on astronomy, and [...] were shown 'Venus at its brightest' and 'two large sunspots"' (p. 43). Hedges, too, takes informal lessons at the nearby observatory: "He left Phil at the telescope for another ten minutes. Soon the boy began asking sensible questions. Drawing him away at last, Hedges said, 'You can come up at night. I'll show you Mars. And Venus"' (p. 104).

Idiosyncratic detail, fondly remembered in the school history, is re-used in the novel. Drawing on Gibbs' bitten ear, Gee gives to Hedges an ear “mauled as though by a cat" (p. 21). Exactly replicating Gibbs' teaching aids, Gee equips Hedges with a tuning fork, magnifying glass, and thermometer. Moreover, Gee appropriates Gibbs'skeleton to enable Hedges to teach biology in a similarly entertaining way. Like Gibbs' skeleton, Hedges' skeleton has a female persona. In chapter two it is viewed by the boys as they remove it from the school belfry's cupboard:

[Noel] opened the cupboard and [he and Phil] looked at Miss Perez. She glimmered at them, smiling, with her head bent in a regal way. Her slender feet were in line with their knees, her hands, palm up, at her waist, seemed to offer, but the rest of her, so empty, seemed to want. (p. 23)

Drawing on Gibbs' divided nature, Gee makes Hedges similarly mixed. Such a view emerges in The Fire-Raiser from the "swimming hole" sections, which are based on material in Nelson Central School. In each account the swimming trip represents bliss. Regarded fondly, each headmaster demonstrates likeable idiosyncrasies, encourages children to practise swimming on the bank, tests the water temperature with his thermometer, and throws a tin lid into the water to provide a goal for diving. Furthermore, each headmaster becomes involved in a dispute with the owners of land surrounding the river who claim the waterholes as their own, with each enjoying a good fight and intent on winning. Both Gibbs and Hedges dismantle private property notices and persist in the swimming trips anyway. 
In Gibbs' case the "war with Mrs Richardson” led to Mrs Richardson's drastic action. Gee records: "She stole the boys' clothes while they were in the water, but Gibbs told them to dance naked round her house and Mrs Richardson quickly gave the clothes back" (p. 49). The ensuing court proceedings resulted in a triumph for Gibbs, although that did not stop him blocking the Richardsons' hydraulic ram.

In Hedges' case the waterhole dispute leads to the Marwicks' similar retaliation: "The boy came running from the scrub. 'Someone's taken our clothes" (p. 38). Hedges and his class approach the Marwicks: "Hedges smiled. He liked a fight. [ . . ] 'Where's my redskins? Where's my warrior boys? Come out. Do a dance for Mrs Marwick.' [ . . ] They began leaping up and down, flinging their skinny limbs and howling at the sky" (p. 40). Mrs Marwick hastily returns the clothes. Later, continuing the war, Irene blocks Marwick's hydraulic ram.

For Gee the waterhole incident seems to have embodied Gibbs' divided self. Gibbs also had an ambivalent attitude to war. Gee notes in Nelson Central School Gibbs' dislike of jingoism, pomp and ceremony, and his defence of German music teacher Herr Lemmer against racist attacks. But Gee also records Gibbs' fascination with battles, noting: "In the Great War he could always be side-tracked into discussing tactics. [...] Gibbs would be so absorbed with his maps, marking the battle lines with flags, that lessons were forgotten" (p. 46). Gibbs led classes in singing patriotic songs: "Gibbs would come through the school to each class, strike the front desk with his [tuning] fork, and lead the boys in the singing of patriotic songs - Hearts of Oak and Rule Britannia” (p. 43). And the School contributed to the Belgian Relief Fund and knitted socks for soldiers.

Hedges dislikes pomp, ceremony, and “jingoistic huff and puff” (p. 111), and defends German music teacher, Lotte Stauffel, from anti-German attacks. But Hedges is also easily persuaded into leaving lessons to discuss war as he does in chapter two, relinquishing arithmetic to discuss the British capture of Neuve Chapelle which he plots on a wall-map "pinned with flags in a crooked line" (pp. 21-22). Further recalling Gibbs, Hedges uses his tuning fork to lead the children in patriotic song: "He took out his tuning fork instead and banged it on his desk and only began to simmer down when he heard its note" (p. 20). Similarly, "Hearts of Oak" and "Rule Britannia" are sung at the school pageant, whilst Mrs Chalmers contributes to the Belgian Relief Fund and Mrs Wix knits socks for soldiers.

Gibbs' complexity, it is hinted in Mann's biography, may have been partly due to his intense relationship with his mother. According to Mann, Mrs Gibbs was a strongwilled woman, widowed prior to the family's departure from England. By sheer determination she established a domicile in New Zealand and brought up her nine 
children single-handed. An early marriage proposal by F.G. Gibbs (to an unidentified woman) was turned down, and he devoted himself to his work and community service, and lived with his mother until her death. Gee notes that for the rest of his life Gibbs remained a bachelor living on in the family home.

Gee seems to have Mann's material in mind in depicting Hedges as a man who may have had a difficult relationship with an imperious female. In chapter two Hedges' suffering is suggested by his facial disfigurement - his nose possibly mishapen by a human thumb, his pitted skin the result of childhood illness, and his ear mauled as though by a "cat" (a derogatory term for a malicious woman):

He was a square-built man with an ugly face: nose like plasticine dented by a thumb, eyes that went one this way, one that, but saw well enough, and mouth like a leather purse, full of crooked teeth. His skin was pitted from some childhood illness and one of his ears mauled as though by a cat. (p.21)

Certainly in 1915 Hedges is dominated by the autocratic Mrs. Bolton who sees herself "locked in battle with him, fighting for Christian behaviour, right belief of every kind" (p. 25). Like Gibbs, Hedges is an atheist, middle-aged, and a bachelor.

\section{Gee's Refashioning of the Nelson Material}

However, Gee does not simply transpose characters and events from Nelson Central School to The Fire-Raiser in a straightforward fashion. For instance, Gibbs' brutality is more often expressed in the novel through Marwick rather than through the relatively inoffensive Hedges. And Gibbs' living arrangements with his mother are more closely replicated in the Marwicks' domestic life. Indeed, diary accounts and biographical detail about Mrs Gibbs might have provided a model for Mrs Marwick who is similarly strong-willed and autocratic, and who dominates a middle-aged bachelor son.

Furthermore, Gee apparently takes Mann's account of the Gibbs family's immigration to New Zealand, when Gibbs would have been about ten, and gives it to an approximately ten-year-old Julia Marwick and her mother. Where the Gibbs family sailed from England minus Mr Gibbs, who died of illness prior to the departure date, Julia Marwick and her mother seem to have sailed from England without Julia's father (who goes unmentioned in the novel).

By tempering Gibbs' character in his construction of Hedges, and by combining the dramatic elements in Blecher, the Richardsons, and the Gibbs to form the Marwicks, Gee sets the rational Hedges and the irrational Marwicks against each other. 
Thus he reveals his interest in division, and in simplifying the historical characters hints at a symbolic truth in The Fire-Raiser.

Echoing Nelson during Gibbs' time (as documented in the school history), Jessop in the novel is redolent of war. But Gee gives a figurative dimension to the period's conflicts between traditional and liberal, and empire and nation. Where images connected to Gibbs have a literal significance, those connected to Hedges become emblematic - Gibbs' tuning fork, magnifying glass, and thermometer suggest his interests and idiosyncrasies. But in relation to Hedges, these images connect him to the novel's themes. Associated literally with "tuning", the tuning fork as a symbol is used by Hedges to harmonise himself and his class: it is when he hears its note that he simmers down (p. 20). Similarly, Hedges' thermometer and magnifying glass that enable him in the scientific sense to measure and see, ironically emphasise a reluctance to acknowledge human nature's unpleasant side, as is apparent in chapter two: "He was oppressed [...] by a knowledge of meanness, cruelty and pain, all waiting round corners, but $[\ldots]$ he believed one must carry on as though life were the happy thing it could be" (p. 21).

Distinct differences in the appearances of Gibbs and Hedges suggest Gee's wish to expand on Gibbs' contradictions whilst showing that in Hedges these traits are controlled. Where Gibbs is rotund, and in the biography's photograph has a direct gaze, regular features, and is reasonably good looking, Hedges is square, cock-eyed and ugly (p. 21). Ironically it is the facially perfect Gibbs whose rotundity suggests brutality, whilst the facially flawed Hedges, whose squareness suggests order, aspires to humanity. Although Hedges' face reflects an abusive past, he more often than Gibbs is relentlessly controlled. Where Gibbs expressed his anger by thrashing children, Hedges checks his impulse to use the strap on Noel and Phil: "He strode to his table and took his strap and let it fall out to its full length. [...] He rolled his strap and threw it in the drawer" (p. 32).

Indeed, recalling Renaissance/Classical beliefs that heaven's harmony could be heard in the musical concordances of the stars, Hedges seems to hear such a sound. In chapter nine during an informal astronomy lesson with Phil, he comments: "When you look up there at night $[\ldots]$ you can hear a kind of harmony" (p. 104). The idealised perception of the cosmos that distinguishes Hedges from his historical model seems to epitomise his inclination to confer order where none exists. In other words, Hedges possesses the artist's creative imagination and may therefore parallel Gee.

Gee's tendency to adopt yet transform material from Nelson Central School is obvious in his treatment of the waterholes which function as a link between the school and the Marwicks. In the school history there are three holes - "Girlie's", "Dene's" and 
"Sunday". In the novel there are only two - the aforesaid "Girlie's" and (Gee's own name) "Buck's". Gee's concern with duality is therefore neatly encapsulated. For Gibbs the pools were just pools. But Gee's pairing and naming make them images of the divided whole. Thus in chapter three Buck's Hole is the scene of romance, excitement and adventure, whilst in chapter eleven Girlie's Hole is the scene of near drowning and death.

The beauty, desirability and co-operation of diverse features - red and white, coldness and warmth, speckled and clear, flow in and flow out - are what Hedges registers when he first contemplates Buck's Hole. At the same time the encircling frame of breathless suspension, and the run-on sentence and lack of verbs and therefore action at the centre of this extract, suggest tranquillity and peace. Hedges' epiphany certainly echoes Raymond Sole's criteria for wholeness and balance, and in this moment reflects his inner harmony:

\footnotetext{
The loveliness of this pool took his breath away. It always happened. The sand and shingle, oatmeal coloured, with red pebbles, white pebbles, speckled ones and brown, strewn about like some Caliph's treasure, and the water with the clarity of air and the coldness of stone, and the mossy banks, the bush with caves of shadow, the flow in, brittle, pure, the flow out, smooth as glass, and the green deeps, with the river floor somehow warm at the bottom - it held him in a moment of delight. (pp. 35-36)
}

Hedges' battle with the Marwicks over riparian rights further exemplifies Gee's investment of historical material with an emblematic dimension. As described in Nelson Central School, the waterhole dispute between Gibbs and the Richardsons led to a vicious court battle, with Gibbs unleashing his fury in, for instance, his use of corporal punishment. The Fire-Raiser's battle, however, is experienced less emotionally by Hedges and it is Marwick who becomes aggressive. Even in the fight between Hedges and Marwick, Hedges exercises restraint. Gee's depiction of this fight in comic terms, and Hedges' deliberateness of action and self-awareness, suggest his unwillingness to allow passion to dominate. Whilst resorting to the physical Hedges, in contrast to Gibbs, suppresses anger, and remains controlled:

\footnotetext{
Hedges took off his jacket. He folded it and laid it on the ground. He unfastened his watch from his waistcoat and put it on top of the jacket. Then he faced Marwick. He put his left leg forward and doubled his fists and stood waiting. There was something comic in it, he knew. (p. 129)
}

Gee refashions history in a similarly emblematic way in depicting the Marwicks. He conflates the villainy of Johann Blecher, the Richardsons, and Gibbs, to form the characters of the Marwicks who are more evil than any single character in Nelson Central School. Gee then sets the Marwicks against Hedges with his ideals of balance and 
harmony. Furthermore, where Blecher was a German immigrant bricklayer and working class, and where the Gibbs family were English middle class and landed gentry, the Marwicks are English upper class who associate with aristocracy. The Marwicks' elevation suggests they are representative of Empire, a position they have enjoyed in the novel's past, which allows for them to be seen in more general terms as imperious. Finally their elevation heightens the sense of their fallen states that occur first in the past in material and social terms with immigration to antipodean New Zealand, and second in the present in moral and religious terms.

Differences between the sea voyages of the Gibbs and Marwicks are also interesting. The Gibbs family sailed from England in April of 1877 when Gibbs was ten. ${ }^{11}$ As estimated from the novel's detail, the two Marwicks would have sailed in about 1855 , with Julia aged approximately ten. ${ }^{12}$ Gee therefore adapts source material to allow Mrs Marwick's memories of the voyage to be of herself at much the same age as the four child protagonists, whilst being consistent with the novel's World War I setting. That Gee gives Mrs Marwick a childhood allows Kitty to empathise when she hears her recollections in chapter eight.

Thus Gee provides an insight into the suffering underpinning Mrs Marwick's brutal treatment of her son. The parents' corporal punishment of Marwick, and Marwick's appetite for fire make the Marwicks emblems of fatally unrestrained passion, at the opposite end of the spectrum to Hedges who stands for harmony and control. Paradoxically, then, Gee achieves wholeness by stripping the historical figures and situations of their moral and psychological complexity to make Hedges more thoroughly good, and Marwick more thoroughly evil, and English rather than German. Together the Marwicks and Hedges represent tendencies that to varying degrees exist in all the novel's characters.

\section{War}

As stressed by Hedges in chapter two, harmony and music on the one hand, and destructiveness and fire on the other, are antitheses. Put slightly differently, Hedges (speaking for Gee) seems to see art and war as opposed. That Hedges refers to these antitheses in terms of "phrenology", a "mind full of flames", and "psychology" suggests that for Gee they represent the opposed sides of the split psyche, and the Hedges/Marwick dichotomy. Simultaneously Gee seems to suggest the possibility that harmony, music, or art may be a corrective or balancing force to destructiveness and war: 
Hedges felt the shape [of Miss Perez's] head with both hands. 'Some people would say that shows she's musical. This little bump here' - he put his finger on a bulge above the skull's ear hole - 'represents harmony. But of course, phrenology isn't a science any more than astrology is.'

[...] 'Destructiveness is here' - he touched the place - 'very close to music, strangely enough. But it's all nonsense. All we can say is, whoever lights those fires has got dark things in his mind. Or perhaps his mind is full of flames. Now that's a science, a brand new science called psychology.' (pp. 24-25)

Gee's concept of parts, then, involves an exploration of the arts and war. As we have seen, the school history's references to war are echoed in the novel. But Gee narrows the novel's setting to specific dates just prior to the battle of the Anzacs at Gallipoli. He imbues the personal (the material sourced from Nelson Central School and F. G. Gibbs) with a larger dimension (war and Empire as inherent in the national psyche) and adjusts the novel's structure accordingly. Thirty-three years of historical material (from Blecher's first fire in 1890 to the year of Gibbs' retirement in 1923) are fitted into sixteen days (from Marwick's first fire on 23 March 1915 to his last fire, estimated as occurring on 8 April 1915). The compression of a broad chronology into a defined period enables Gee to intensify the theme of war. References to specific dates and battles of World War I suggest that a consideration of the novel's location in time and war's opposed sides is essential.

The novel starts with an implicit reference to war's opposed sides. Marwick's burning of All Saints Church on Christmas night 1914 occurs on the exact date of an unofficial truce in Flanders when Britain and Germany picnicked and played football in "No Man's Land". The truce was a brief respite from the fighting. ${ }^{13}$ In chapter two Hedges discusses with his class events following the truce, including the conflict at Neuve Chapelle, a small village in southern Flanders/France. Occupied by the Germans, Neuve Chapelle experienced the first British assault on 10 March 1915 when the front trenches were taken. ${ }^{14}$ By 12 March the British and Indians had captured Neuve Chapelle and destroyed the village's salient west.

Hedges and the children then discuss the Turks' floating of mines in the Dardanelles, and the blockage of the Dardanelles by British and French ships. Turkey's closure of the Dardanelles cut Russia off from western Allies, but on 18 March 1915 the Anglo-French fleet attempted to force through the Narrows at Chanak; their aim was to cross the Sea of Marmara, seize Constantinople, eliminate Turkey from the war, and undermine the Central Powers. The minefield laid by the Germans and Turks prevented this and caused the loss or destruction of French and British battleships. ${ }^{15}$

In chapter ten the class again discuss war with Hedges who states that Przemysl, a fortress town, is important because it is situated on a river. Close to the Austro-Hungarian 
border, Przemysl was crucially located between uplands and lowlands in the San River valley. With numerous "parent" nations, it had been a military and religious seat since the fourth century BC, and contained many ruins (including an ancient castle, churches, and fortress). ${ }^{16} \quad$ In World War I Przemysl became a critical area of combat between the Austrians and Russians. Under siege since mid-September 1914, it surrendered, and the Russians finally captured it on 22 March 1915 (the date mentioned by Hedges). ${ }^{17}$

The children also mention the Russian fleet's bombing of the Bosphorus, the final barrier between the Sea of Marmara and Black Sea, and recall New Zealand's victory over the Turks in Egypt. All these events preceded the landing of Australian and New Zealand forces on 25 April at Anzac Cove (near Cape Helles in Gallipoli) and the hopeless battle against fiery Turks. The battle at Gallipoli was to become a myth within the national psyche. According to historian Philippa Mein Smith, "the official version of the legend celebrated [...] the glory of the Great Sacrifice". It was only in the 1980s, when veterans reaching old age told their stories, that the myth was questioned. ${ }^{18}$

Gee's treatment of war in The Fire-Raiser reveals his concern with division and balance. On the one hand the school material and the period of war are compressed into a sixteen-day sequence which comprises a fragment of time - half a month. On the other hand, this fragment seems to be set against the twelve-chapter sequence that, recalling the twelve calendar months and the twelve signs of the zodiac, for example, perhaps hints at traditional ideas of wholeness. Thus the dichotomy of the fragmented Marwick (emblematic of war) and the more balanced Hedges (emblematic of harmony) is recalled.

Rather than directly echoing the armistice in Europe Gee gives us in Marwick's burning of All Saints the ironic opposite: a rejection of community and worship, and a birth that is not Christian but demonic. In making the English Marwicks deeply flawed rather than heroic, Gee echoes the view prevailing in the 1980s and provides a corrective to the official version of the Gallipoli myth as a great sacrifice. And in making the German Lotte Stauffel kind rather than nasty he provides a corrective to the common perception of Germany as enemy.

With allusions to war zones Gee implicitly emphasises conflicts leading up to the novel's opening on 23 March 1915 and the battle at Gallipoli. Quite deliberately, it seems, he organises the allusions into two parallel sets, each including a waterway, a township, and battles between conflicting forces. In chapter two the Turks' triumph in the Dardanelles, and the British capture of Neuve Chapelle (located on Allies' territory and occupied by Germans) are emphasised. In chapter ten the emphasis is on Russia's bombarding of the Bosphorus and capture of Przemysl (located on the Central Powers' 
territory, to be captured by Allies). Whilst giving equal weight to war's opposed sides and their victories in each half of the novel, Gee suggests the children's bias. They rue Turkey's laying of minefields in the Dardanelles, but celebrate Russia's bombarding of the Bosphorus. They celebrate the British recapture of Neuve Chapelle from the Germans, but they also celebrate Russia's capture of Przemysl from its "parent" nation. That the children cannot see that the victories of the Allies and Central Powers are similarly destructive will, Gee may hope, cause the child reader to see otherwise.

As though seeking to teach the child reader about war's evils, Gee establishes smaller battles and battle sites in Jessop that involve similar features. Where Neuve Chapelle (named for its churches) was destroyed by the British, Marwick burns Jessop's church, and Dargie's Livery Stables (with its roof "tall as a church" p. 8). Where the battle over the Dardanelles involved a waterway, the Marwicks' battle with Hedges and the children involves the waterholes. Where the Turks sank mines in the Dardanelles, Marwick sinks a lethal motor spirits can in Buck's Hole.

Like the fortress town of Przemysl, Jessop has a cathedral (p. 136), and a river, as Phil notes in chapter seven: "He had walked to the rivermouth and watched the tide running over the mudflats. He followed the river into the town" (p. 77). To Marwick Jessop is "hostile, like a fortress" (p. 66). Where Russia captured Przemysl and bombarded the Bosphorus, Marwick destroys the warehouse and attempts to bombard the swimming children (by chopping down a nearby tree). Thus Gee encourages the child reader to look critically at Marwick and also at the Allies.

War permeates characters' thoughts. Following the fire at Dargie's, Marwick's belief that "the fear around him, all of it [is] a tribute" (p. 15), his hooked finger salute, and balaclava (a headpiece worn originally by soldiers in Balaclava during the Crimean War) suggest he sees himself as a heroic soldier. When he advances through Jessop towards Chamers' Warehouse he imagines himself in a war zone: "He went through a building site, sliding on piles of sand, and climbed a bank into palm trees that sharpened their sword-leaves on each other" (p. 67). And when he leads the mob in the attack on Lotte Stauffel's place, he acts as an army general: “Enough talking, boys. Follow me.' He went out the door, and not only the young men followed him, but older ones" ( $p$. 119). Perhaps, then, Marwick (and implicitly the Allies and British Empire) are set up for criticism by the child reader. 


\section{Symmetries of War and Peace}

Whilst aligning characters with the opposed sides of war, Gee shows differences within sides. Placing the Marwicks together at the end of the sixth out of twelve chapters, at the novel's very centre, he emphasises their division. Here, the narrator in a sense invades the Marwicks' fortress-like home, to reveal the "hero-soldier" (or fearful fire-raiser) as helpless child when confronted by his powerful mother: "[Marwick] turned and faced [his mother], with his back to the door. He looked at her from under his brows, like a child, afraid, in disgrace, but still defiant. [...] Things revolved about her" (p. 74). But although pivotal to Marwick, Mrs Marwick is effectively imprisoned in her home and in the novel's central chapters by Gee, who at this point balances images of domination and submission. Gee also allows the child reader to see the suffering that underpins Marwick's destructiveness.

Gee provides a further balance by pitting the militant Marwicks against major characters who are predominantly good. There are twelve of these who collectively represent a whole that can be further divided. For example, there is a group of four children (Irene, Kitty, Phil, and Noel) and a group of eight adults (Mrs Bolton, Mrs Chalmers, Mrs Wix, Frau Stauffel, Hedges, Mr Wix, Mr Chalmers, and Sergeant McCaa). The two groups of four children and eight adults span the full range of the emotional continuum from the aggressive Mrs Bolton, to the weak Mr Chalmers. The group of four children comprises two females and two males, and the group of eight adults comprises four females and four males. Furthermore, the group of four children includes two siblings (Noel and Kitty) and two only children (Irene and Phil), whilst the group of eight adults includes two sets of married couples (the Chalmers and Wixes), and two sets of single males and females (Sergeant McCaa, Mrs Bolton, Frau Stauffel and Hedges). The characters vary in physique from the large Kitty, Phil, Mrs Bolton and Sergeant McCaa to the small Irene, Noel, Frau Stauffel and Francis Chalmers. Together with the Marwicks, the groups of children and adults form a continuously increasing pattern of opposed pairs, from the single pair of Marwicks, to the two pairs of children, to the four pairs of adults. Positioned as the three groups of pairs are within the novel's twelve chapters as an image of a whole, they seemingly resemble opposed points on a circle's circumference.

With its emphasis on two, three, four, eight, and twelve The Fire-Raiser, like the $O$ trilogy, seems to have an underlying numerological structure. As discussed by Nozedar in considering numbers as symbols, two represents division, the pairing of people, and dualities such as day and night, heaven and earth, and man and woman. Four, Nozedar claims, recalls the four cardinal directions, the four evangelists, and the four elements, and "gives us the potential not only for the square, but also for the cross". In contrast to three 
or the trinity which is connected to Heaven, four is connected to Earth whilst having about it "a wholeness [that] provides the framework for the exuberant, circular mandala". Eight, according to Nozedar, is "a symbol of cosmic harmony and balance". It recalls the intercardinal points, and the corners of a cube, and was considered by the Pythagoreans to be sacred in that it was the only "evenly even" number (a multiple of two by four, or four by two) under ten. Twelve, Nozedar states, recalls the twelve calendar months, the twelve signs of the Zodiac, the twelve Apostles, the twelve hours of the day, and twelve hours of the night, and so on. It is the result of multiplying three by four, and thus combines Heaven and Earth to represent the whole universe. Nozedar notes that as far back as "Ancient Man" twelve was "a number of perfection. ${ }^{19}$

Gee thus seems to use numerological structures as a way of controlling darker forces at work in his novels (much as he uses historical realism and literary allusion to anchor the novels in meaningful realities). However, these structures seem to evolve naturally. As Jung has commented, numbers and symmetries have a mythical and archetypal significance, and appear in nature. In other words, M. L. von Franz claims, "numbers are not concepts consciously invented by men for purposes of calculation; they are spontaneous and autonomous products of the unconscious - as are other archetypal symbols". 20 When considered collectively, Gee's numerological structures control the novel and contribute to its shape as a mandala.

Crucial to the novel's immensely symmetrical structure is Hedges. Psychologically complex yet controlled, physically mobile yet mentally stable, not yet married but about to be, and neither young nor old but middle aged, Hedges occupies a central place within the groups of characters. As such he is a mediator between children, between adults, between children and adults, and between the Marwicks and others. $\mathrm{He}$ therefore functions as the archetypal wise man, or ego-hero who must hold the distressed system's warring sides still. Together with Frau Stauffel, his complementary opposite, he is a stabilising force that balances the Marwicks' negativity. As though making the book a fortress, Gee establishes infrastructures that stand solid against the Marwicks, imprisoned within.

However, the twelve mainly "good" characters are also realistically divided and delight in war. In chapter two Hedges and his class enjoy discussing the wall-map and battle tactics. In chapter three the girls squabble, Noel and Phil wrestle, and Hedges bellows and threatens them with the strap. In chapters three and seven they invade the Marwicks' property and war over the waterholes. Mrs Marwick herself claims in chapter six that it is "quite an invasion" (p. 72) when Noel, Phil, Hedges and Sergeant McCaa intrude on her premises. Situated on the river, the Marwicks' house resembles a 
battleship: It is "big and ugly and threatening. The windows in the bows [are] like bulbous eyes watching them". Similarly, the hydraulic ram recalls the ship's ram (a weapon of war): "A regular, flat thumping sounded above the noise of the rapids. [They] came to the machine bolted to a platform " (p. 79).

Indeed, war pervades the children's thoughts. When the boys bring Marwick's lethal motor spirits can to the surface of the river, and see it as "half buried in silt which sprang up like smoke at their touch" (p. 42), they seem to remember the threat of Turkey's sunken mines. Certainly the shelling of the Allies' boats is recalled in chapter five when the boys, by the river, are "shelling [sticks] with pebbles" (p. 59). It is not only Marwick who attacks Jessop, then, but also the children who attack Marwick. Irene pierces the ram's hose with her hairpin and Phil pelts Marwick, with "first the hinge, then the whetstone, last the nails, one by one, like daggers" (p. 86). On a microcosmic level the children therefore echo World War I in Jessop.

Marwick's suffering at the children's hands contributes to his mental imbalance. In effect, the four children see the Marwicks not as an individuals or in terms of their British culture as "right", but as a projection of their consciousness of war and, romantically, as the enemy to be heroically defeated. Not only must they come to terms with the Marwicks' history, culture and suffering but also, through knowing them, they must recognise the cruel side to themselves. That the destructiveness of Marwick and war is echoed by the child characters with whom the child reader will identify, would encourage him/her to look critically at self, family, friends and, of course, the Allies in war.

Gee also suggests to the reader that some wars are worthwhile. Broadly opposed, Marwick and Hedges have much in common, but finer differences exist. Both are invasive and attack English culture. But where Marwick invades others' territories to play soldier by night, Hedges enters others' properties to play saviour by day. Marwick rebels against his English mother, and destroys monuments embodying her culture, for example, All Saints Church and Lotte's piano. But Hedges rebels against the matriarchal Mrs Bolton and Chalmers who believe they are English, and attacks their pretension. Mirror images of each other, Marwick represents "war" as evil, whilst Hedges represents "war" as good. Gee thus balances positive and negative ideologies, and criticises the destruction of the former, but affirms the destruction of the latter. As we shall see, the school pageant plays a part in Jessop's war, and contributes to balance. 


\title{
The Original Pageant
}

Although Hedges sees music and destructiveness as opposed, he also emphasises the proximity of their representative cranial bumps: "Destructiveness is [...] very close to music" (p. 25), he tells the children. Gee similarly suggests that war and art are close. The patriotic pageant, for example, brings verse and song together with the militant. Interestingly, as Gee has acknowledged, the novel's pageant is based on the script of a real school pageant that celebrated Empire Day. Gee has described his discovery of the original pageant:

\begin{abstract}
I found it in the library at the Auckland Teachers' College when I was working there in 1973 or 4 was it, and I came across this old box of papers. It was a pageant that a school had presented in 1917 or something like that, and written by one of the teachers. So I photocopied it. I didn't steal the original. I don't know what's become of the original. Presumably it is still up there in the library. I photocopied that and used it (amended it here and there) in this book. I didn't plan that. I just suddenly thought [ . . .] this is a good bit of business to put into the book. ${ }^{21}$
\end{abstract}

Comprising some thirteen pages and written in various cursive styles, the script has apparently been hand-copied by different children for the actors. Entitled Our Empire Day, it commemorates the King's official birthday (which in 1917 occurred in June) as was the usual practice in patriotic New Zealand schools at the time. Intended for performance in a school playground, it is divided into two parts.

Part One depicts the British Empire, and France and Belgium threatened with German invasion early in World War I. In August 1914 Germany, intent on attacking the newly mobilised France, had issued neutral Belgium with an ultimatum that insisted on right of passage through her territory. Although Belgium rejected the ultimatum, German forces crossed the frontier. Britain's Liberal Cabinet therefore declared war.

In Part One, then, the British Isles are represented by a Britannic group and a lead character named Britannia who calls for the support of characters named N. Z., Canada, India, Egypt, Australia, S. Africa, Zealandia, Colonial groups, and the Dominions and Colonies. Also included are soldiers, sailors, miners, Red Cross nurses, and various helpers (all referred to as "troops"), and Wisdom and Young Strength. Representing Empire, these characters plan to fight Germany (referred to only by name). Included are pleas to Britannia and the Britannic group for help by France and Belgium who draw on "the sincerity of the friendship which has joined our peoples since the days of your good and great King Edward, the Peacemaker, son of the good Victoria” (p. 1). ${ }^{22}$ They are answered with expressions of duty, power, compassion, and loyalty by Britannia, the Britannic group, and Empire. Inserted into the dialogue are patriotic verses and songs such as "Land of Hope and Glory" (p. 8). Great Britain is personified as "Mother of 
Nations" (p. 4), "dear Motherland" and "Mother of the Empire" (p. 7), whilst the dominions and colonies are addressed as "Old England's sons" (p. 3), "brothers" (p. 6), and "dear children." (p. 8). Germany, on the other hand, is referred to as "imperious Kaiser" (p. 1), "perfidious Germany" (p. 2), or "German bully" (p. 3). Finally troops exit singing "It's a long way" (p. 11).

Part Two of the pageant, according to a marginal note (p. 12), is condensed from School Journal, Part 3, June 1912 (an Empire Day issue). Entitled "Saluting the Flag", it has cadets in uniform as Guard of Honour, and a Union Jack aloft in the centre. It comprises chants by A Child; the North, South, East, and West Winds; Another Child; and the cadets' sergeant and captain. Finally the Headmaster orders: "All eyes to the flag. Boys right-hand salute, girls bow - teachers participating. Cadets fire a salute". Again troops exit singing "It's a long way" (p. 13). The pageant certainly emphasises imperial ideology. Its one-sided point of view (that of Great Britain and the Allies), inflated tone, and didactic message typify the attitudes of the times.

\section{Gee's Pageant}

In The Fire-Raiser Gee's pageant replicates much of the original. Irene's words as Belgium (“O, Britannia, Britannia, pity our distress!”) and Kitty's words as Britannia ("Poor little Belgium", p. 58) are exact repetitions. Verse spoken by the Britannic group is identical to the original except that the final two lines ("So wield we still, gainsay who will,/The sceptre of the sea") are omitted and it is sung by the whole choir:

\footnotetext{
Old England's sons are English yet,

Old England's hearts are strong;

And still she wears her coronet

Aflame with sword and song.

As in their pride our fathers died,

If need be so die we ... (p. 116)
}

However, Gee makes telling adjustments to the original pageant's script. For instance, he detaches the fictional pageant from the original's Empire Day context, thus making it relevant to events occurring during the novel's timeframe, which directly precedes the Anzacs' battle at Gallipoli. Great Britain's and New Zealand's entry into war in 1914, political events of 1915, and Jessop's wars are therefore contextualised for the child characters and reader.

In re-naming the pageant "Britannia Awakes" Gee makes connections to themes of consciousness, sight and life versus unconsciousness, blindness, and death. The fictional pageant's title therefore suggests Great Britain's awareness of responsibility for 
Belgium and her allies, and the call to fight, but also the children's growing knowledge of Marwick and war as deadly and real. In setting his pageant's performance not in a playground, but a school hall, Gee emphasises balance, for the tri-partite backdrop places neutral Belgium in the centre, and the opposed England and Germany on either side: "The centre [panel] showed green fields, red poppies, yellow cows: the fields of Belgium. On the left were the white cliffs of Dover, with blue sky and a little church. On the right a forest of dark trees was bending in a storm" (p. 110). Gee, moreover, inserts extra parts into the pageant. These include Ghurkas (Nepalese soldiers) and Wipaki (a Maori in a grass skirt), both parts of the British forces; and Hun soldiers, Turks, and a Prussian squad (all aligned to Germany and the Central Powers). Most significantly Gee includes the Kaiser and gives him and New Zealand major roles.

Britannia's script also changes. Rather than repeating the original "my people" (p. 2) and "my dear children" (p. 8), Britannia addresses the Colonies and Dominions as “sons and daughters" (pp. 56, 116, 117). Words, originally Belgium's, are adapted and given to Noel as Kaiser. Where Belgium cries: "Perfidious Germany [ . . . ] ignores her pledge calling it but a scrap of paper and says that Might is Right" (p. 2), Noel as Kaiser proclaims: "Might is right" and adds: "Power is my reward. I trample through the green fields of France. I tear this poppy Belgium from her stem. My heel shall grind her petals in the mud" (p. 58). Playing New Zealand, Phil also conflates characters' original scripts, with Zealandia's speech adapted to: "Mother of Empire! Our New Zealand home is so far from the white cliffs of Old England that it might be thought we had forgot those from whom we sprung. It is not so! Furthest flung of your Empire we may be, but our character and customs are your own. We are the Britain of the South ...” (p. 116). And Phil utters a rousing verse originally performed by Canada:

Who would not fight for England?

Who would not fling a life

I' the ring to meet the tyrant's gage And glory in the strife? (p. 116)

Most significantly, the climax of Gee's pageant occurs when Britannia kills the Kaiser. Following this, with flags waving on the stage, Phil draws the pageant to a close by repeating A Child's lines from "Saluting the Flag": "The foeman will find neither coward nor slave, Neath the Red Cross of England the flag of the brave" (p. 117).

Gee's pageant strongly emphasises division and World War I's conflicting forces. By including Ghurkas with the British forces, and the Kaiser, Huns, Prussians, and Turks as foe, Gee offsets the original version's one-sidedness. Although Gee's pageant still reflects the glory of war and the British side as right, both sides are parodied. That 
Britannia (played by Kitty) is cold and stern, whilst the Kaiser (played by Noel) is comic and immensely likeable, evens out the sides. Recalling Hedges, Gee wars on imperialist ideology to present a more balanced view of history.

Moreover, by personifying Britannia and the colonies as "Mother" (pp. 59, 116) and "sons and daughters" (pp. 58, 116, 117) Gee parallels political and familial structures. In having Kitty as Britannia kill Noel as Kaiser, Gee reverses and ironically balances Edgar Marwick's killing of his sister Lucy. That Gee does not personify the Kaiser as "father" de-emphasises his destructiveness and emphasises Britannia as destructive mother. In naming Irene’s part “Gallant Little Belgium” (pp. 27, 30), a term omitted in the original pageant but commonly used during World War I, Gee suggests the vulnerability of children subjected to conflict involving adults. Thus the child character and reader have a means of understanding war's destruction on their level. Gee's message to the child reader is clear: whether it is Britannia, Marwick, mother, or child - it is wrong to kill.

In echoing the pageant's war in Jessop's familial wars, Gee creates symmetrical groupings of four. Although the child is pulled between three adults, including a parent and two teacher figures, the destructive is balanced by the creative and wise. Gee accounts for different needs. For example, Irene who needs spiritual nourishment is set against Phil who needs physical nourishment. Irene is placed between a mother who neglects her spiritual needs and a schoolteacher, Mrs Bolton, who imposes imperialist values. But these are balanced by Lotte Stauffel, the music teacher, who offers food for the soul and spiritual freedom. Irene's position reverses her role as Belgium - she is effectively divided between a damaging homeland and colonising British Empire, and a liberating Germany. Phil is placed between a father who neglects his physical needs and Hedges the schoolteacher who imposes his educational values. But these are balanced by kindly Wix the baker who offers food for the body and physical freedom. Phil's position reverses his role as New Zealand - he is effectively divided between a neglectful homeland and colonising British Empire, and a liberating foster nation.

Through occupying contrasting familial and political roles, protagonists are given a balanced view of war, and are positioned to understand the destruction of Neuve Chapelle and Przemysl. Like Neuve Chapelle, Irene is split by parent figures at war over her head. Like Przemysl, Phil is no longer sure who his parent figure is. Along with the child reader, both characters are therefore encouraged to look critically at parents, teachers, homeland, and a motherland that may not be "right". They also have a means of understanding Marwick - a child attacked by a destructive parent, with no saviour to turn to. His suffering at his mother's hands is comparable to Neuve Chapelle's 
destruction by England as "motherland" (or ally), and Przemysl's by centuries of conflicting parent nations. That discussions of Neuve Chapelle and Przemysl are juxtaposed in chapters two (pp. 21-22) and ten (pp. 108-109) against those related to Marwick's fires contextualises war and Marwick for the child reader. Jessop becomes a microcosm of warring Britain and Europe, whilst the child reader is given a view on personal and political levels that is complex and whole.

\section{A Little War in Jessop}

As Gee's pageant progresses from casting to rehearsal to performance, it increasingly becomes part of the novel's reality, impelling opposed characters through movements of reversal. Miscast by Mrs Bolton, the children have roles conferred on them according to physique, so that mentally they operate in conflict with their roles and each other. Irene and Noel are small, extroverted and bold, with the former hating the subordinate role of Belgium and desiring to play Britannia, whilst the latter relishes any role and plays the Kaiser to the hilt. Kitty and Phil are large, introverted and shy, with the former preferring the minor role of Belgium to Britannia, and the latter wishing not to be in the pageant at all.

Symmetrically organised by Gee, the two single children are complete opposites as are the two siblings, whilst the two girls are opposed as are the two boys. Irene is bold and quick-tempered, as we see in chapter four: "She was white as flour, but two little patches of red stood like a fever rash on her cheeks. Her lips were crumpled like paper. Then she stamped. She made a movement with her hands as though tearing something in pieces" (p. 45). Conversely, Kitty is cowardly and shy. In chapter one she is "scared of the dark" (p. 12), and facing Irene she cannot "shake off her feeling of being ruled" (p. 31).

However, in chapter five, adopting their fictional identities to sign an anonymous letter "Britannia" and "Gallant Little Belgium" (p. 63), Kitty and Irene approach concordance. Briefly more similar, and synchronised with their dramatic roles, they present a united front. In chapters seven and eight, though, again invading the Marwicks' property, they move in opposition to reverse their original stances. Merging completely with their roles, they express previously dormant aspects of their personalities so that Irene becomes cowardly whilst Kitty becomes brave.

Thus Gee's pageant moves into the fictional reality, and Britannia's words during rehearsal in chapter five, "Poor little Belgium, brave but powerless against the foe. Shall she be trampled underfoot?" (p. 58), become manifest in Irene's fears of being trampled 
on by Marwick: "He grew taller crossing the paddock, as his boots ate up the land [ ...]. She imagined she could hear his boots and feel the ground trembling" (p. 82). In effect, the Marwicks' property resembles Belgium, whilst Marwick's trampling on it recalls Germany's violation of Belgium's fields. Forced into a subordinate position (possibly resembling Lucy's persecution and drowning by Marwick years earlier), Irene becomes introverted and fearful, and sees herself and Marwick imaginatively as fairy tale thumbkin/dwarf and cannibalistic giant.

In chapter eight Kitty penetrates the Marwicks' fortress and psychic past. Responding imaginatively, she has "a sudden fearful sense (of the house as) made for giants" (p. 88). She is confronted with images of oppression: "Big heavy chests lined the walls. Pictures in carved frames hung from a rail - cattle with lowered heads, grey lakes, mountains that seemed horned. The trees and flowers had all their colour faded out. [ ...] She tried a door handle, but it was locked and her hand came away coated with dust" (p. 88). But through role-play Kitty's vision increases. Cast by Mrs Marwick as Lucy to play the piano, witness to Mrs Marwick's tale of her childhood journey and, like the young Edgar, shut by Mrs Marwick in a cupboard, Kitty experiences the Marwicks' suffering. In playing Britannia and reciting her speeches, she survives, as she later tells Hedges (p. 100), and becomes more extrovert and courageous. In chapter nine she grows in thought and understanding as a result:

[Kitty] lay on her bed and thought of Mrs Marwick in fine dresses, at garden parties, and thought of her now, in the parlour with the photographs everywhere and the yellow scales on the piano, and felt very sad, and frightened too, at the danger and dreadfulness of life, and the mystery of time passing by and making things old, and things that happened long ago staying alive and turning people into different shapes. And she thought of Lucy Marwick drowning. (p. 102)

Noel and Phil undergo a similar reversal. In chapter two the extrovert Noel as the pageant's Kaiser is comic and weak where in the fictional reality he is thoughtful and strong, and the introvert Phil as New Zealand is brave and strong where in the fictional reality he is tearful and weak: "To Noel, sitting a couple of desks away, it seemed that Phil was going to cry. He saw the greedy look on Bob Taylor's face and knew what Phil would lose by being Kaiser or breaking down” (p. 27).

Making pies at Wix's bakery in chapter six the boys become closer, only to separate again and proceed in opposite directions. In chapter seven Phil feels "compared to Noel and the girls, he [is] grown up" (p. 79) and, plotting an attack on Marwick, Noel does not "like the way Phil [is] having all the ideas" (p. 84). In pursuing Marwick, Noel becomes subordinate, whilst Phil plays a dominant active part, pelting Marwick with shrapnel in chapter seven and penetrating the Marwicks' privacy in chapter nine. Through the 
observatory's telescope he confronts the terrifying "huge half moon $[\ldots]$ pale as marble and smudged with grey" (p. 103), and then its earthly parallel in the flawed, incomplete Marwicks "as startling as the moon" (p. 104). Phil experiences an inward echo of their emptiness that he translates into hunger for which the remedy is food: "He [ . . ] thought of beetroot sandwiches and started feeling hungry. There wasn't much at home for lunch. He wished he'd stuck with Noel Wix. He might have got another pie” (p. 105).

In chapter twelve the boys merge completely with their pageant roles to reverse their original stances and become differently opposed. The more cowardly Noel, like a beaten Kaiser, enters the observatory, afraid: "Noel came in like a rat in the dark. He seemed to snuffle at the room" (p. 138). Phil on the other hand becomes courageous and strong, as though "he [is] on the stage again, playing New Zealand - but this time he [is] sure of himself" (p. 136). He responds to Noel, "I'm not scared of the dark" (p.138) and watches over Marwick, thus completing the pattern of reversal undergone by the four children.

The children's crossovers are echoed in chapter ten when the pageant's performance literally leads to "a little war in Jessop to go with the big one overseas" (p. 106), as foreseen by Hedges in the previous chapter. Characters' suppressed aggression surfaces and Jessop's social norms are overturned. Marwick, triggered by a buried hostility towards his sister's piano music, incites normally well-behaved citizens into a mob riot in which the pageant's roles are extended in real life. Led by the English Marwick (an ironic Britannia), the mob storms the house of the German Lotte Stauffel (an ironic Kaiser). Thus the four children are forced to confront characters as embodiments of nations, and to attack Marwick as the nation that is their ally, and defend Lotte as the nation with which they are at war.

As Jessop and the children are effectively overturned and become differently opposed, the entire novel appears structurally to turn. Phil is aware of a rotation at the beginning of chapter twelve: "It seemed a huge wheel was turning and would not stop. He seemed to hear the rumbling sound it made and a cracking of bones under its rim" (p. 135). With the rise to the surface of the previously buried, the past is expressed, and the future is forecast with Phil's sense of a turning wheel and death seemingly forewarning of Gallipoli. However, whilst there is turmoil within the novel, its structures, composed as they still are by antithetical characters in symmetry, remain intact. Thus Gee integrates reality (the actual war), its fictionalisation (the original pageant), fiction (his pageant), the fictional reality (Jessop's mob riot), and future reality (Gallipoli) and masterfully balances movement and disorder with stillness and peace. He also warns against imperialist ideology even when only depicted in drama. 


\section{Music}

Allusions to music are similarly integrated into the fictional reality to reflect the divisions of war. Great Britain is evoked by references to "Old England's Sons" (p. 116) and "Land of Hope and Glory" (p. 118), both patriotic English songs; "Bonnie Jean" (p. 9), a Scottish song; and "Men of Harlech" (pp. 23, 41), a patriotic Welsh song. And the Central European Powers are evoked by references to the Austrian Mozart; Beethoven and Brahms, both bom in Germany and dying in Austria; the Hungarian Liszt; and "The Harmonious Blacksmith" (composed by the German-born Handel who was English by adoption but European in musical style). Furthermore, musical compositions from each of the two sides are juxtaposed. In chapter ten, upon hearing the pageant's rousing "Old England's Sons”, Lotte Stauffel sends a soft Brahms lullaby into the night as an "act of faith in the goodness of music" (p. 117), thus modifying English patriotism with German Romanticism to reassure Irene. Perhaps Gee, too, is assuring the child reader that what is English or German is not thereby right or wrong.

Musical allusions also bring into the novel's 1915 setting older political conflicts. For example, "Men of Harlech" evokes historical wars between Wales and England. The song originated during the fifteenth century when Wales fought England in defence of Harlech Castle. The equivalent of a national anthem, it embodied Wales' independent spirit. ${ }^{23}$ That Hedges sings "Men of Harlech" after fighting the Marwicks in chapter three suggests a surfacing of his Welsh roots and instinct for war against the English: "[Hedges] began to feel pleased with himself, and liked the excitement of the boys. Soon he began to sing, 'Men of Harlech, wake from sleeping ...' and they took it up. He felt like the leader of a tribe” (p. 41).

In chapter two Gee juxtaposes "Men of Harlech" against "Hark hark the lark", (its libretto taken from Shakespeare's Cymbeline). Thus Gee sets battle cry, heroism, and war against birdsong, nature, and peace. As is suggested by the fuller context of Shakespeare's play, the verse is sung for the purpose of seduction. It not only requires sensuous nature to wake to the morning, but also a lady to "arise" or awake to love:

Hark! Hark! The lark at heaven's gate sings, And Phoebus 'gins arise,

His steeds to water at those springs

On chaliced flowers that lies;

And winking Mary-buds begin

To ope their golden eyes:

With every thing that pretty is, My lady sweet, arise:

Arise, arise! (II, iii, 20-28) ${ }^{24}$ 
Through contrasting musical pieces Gee therefore affirms his preference for harmony over war, whatever the nationality. That Hedges calls on Irene to play "Hark hark" straight after the singing of "Men of Harlech" suggests he feels the same.

Revealing much about its interpreters, music becomes a metaphor for the psyche, and Gee gives us a range of pieces. For instance, Marwick's blindness and egoistic delusions of power are represented by the primitive "music" of his beating ram: "A regular, flat thumping sounded above the noise of the rapids" (p. 79). The ram seems to provide its own applause: "Clap, clap, clap, went a valve, like a heart beating” (p. 81).

Contrasting to Marwick's ram, Irene's interpretation of Handel's “The Harmonious Blacksmith" in chapter five is nevertheless emblematic of her bad temper. "Still cross, Irene sat down and raced through "The Harmonious Blacksmith" - the Handel she had learned for Frau Stauffel. She did not enjoy it, but soon began to like showing off'. Chopin's melancholic nocturne, on the other hand, represents Irene's calmer (but still mixed) feelings: "Music was not for skiting with. So she played a Chopin nocturne, and felt sadness welling up in her, and kept control of it with her fingers, and felt almost happy when it was done" (p. 60). Thus Irene uses Chopin's nocturne as a controlled release of her more sentimental emotion, just as Lotte Stauffel uses the soft Brahms' lullaby to calm Irene.

Lotte's reverence for European canonical composers is echoed in her placement of busts of Beethoven and Brahms on her mantelpiece. Ironically balancing Lotte's worship of these, Hedges, who plays only a tuning fork, projects his musical aspirations onto his skeleton. Miss Perez's vicarious love of an opera singer who has the musical ability she lacks, parodies Hedges' love of Lottie as music teacher, as his "story" in chapter two makes comically clear: "[Miss Perez] was a Spanish lady, a singer at the Manaos Opera. She threw herself into the river for hopeless love of an Italian tenor. [ ... ] The piranhas ate her. [...] The Italian tenor was so upset he sang an aria. It made us all cry" (pp. 23-24).

In a further symmetry, Gee casts Miss Perez as one of eight musical females surrounding Hedges, the other "sirens" being Mrs Bolton, Chalmers and Marwick, and Irene, Kitty, Lotte, and Lucy (in the past). However, the skeleton cannot transmit her musical appreciation to others. Instead Gee does it for her. In the novel's first half, Miss Perez (a puppet-like skeleton who moves when manipulated) is set against Mrs Marwick (a living potent force who manipulates others). Undergoing a reversal in the novel's second half, they provide two further spokes to the circular structure formed by the children's reversals. Thus, in chapter six it is Mrs Marwick who, like Miss Perez earlier, loves a tenor, whilst the opera she repeatedly plays represents her maudlin dream of tragedy or romance. It balances Lotte's dislike of patriotic music by showing that 
what presumably is a canonical composer (of the sort revered by Lotte) can be subjected to an equally over-emotional reception. Mrs Marwick wallows in it:

\begin{abstract}
A sound of music came down the hall, a sound of voices wailing in love or grief. [ ... ] The record ended. [Marwick] heard her winding the gramophone, then it started again, the same record, tenor and soprano howling away. [...] The music swelled and [Marwick] pushed the door open further and looked in. His mother sat in her chair with her stick on her knees. Her head was tilted, cheek on hand, and tears dripped from her chin on to her bodice. (p. 66)
\end{abstract}

Unlike Irene and Lotte when playing Chopin and Brahms, Mrs Marwick is less able to control her emotion. And Gee's use of the verb 'to swell' subtly parallels the audience's dangerously unbridled responses to the pageant's patriotic music. In chapter eleven, blinded by tragedy and dream, Mrs Marwick becomes the doomed "heroine". In a scene with all the trappings of Romantic opera (in which female protagonists so often find their fulfilment in death), she plays out the fate earlier belonging to Miss Perez: "Mrs Marwick [stepped] blindly into the rapids. They knocked her over, pulled her down. She tumbled in white water - arm, shoe, wide-open eyes. Then she floated into the deep, with air ballooning in her dress" (pp. 131-132).

Where Mrs Marwick falls into dream, blindness and near-death, Miss Perez seems to come awake, dance, and live. As the White Lady of chapter twelve, she is satiric evidence of art's power to become integrated in reality (recalling the pageant's arousal of the mob to riot and the opera's impulsion of Mrs Marwick towards drowning). The role of the White Lady originates in the water sprite of Germanic myth who, lacking a soul, seeks the love of a human male, or warns of impending death. ${ }^{25}$ Certainly, as the White Lady, Miss Perez appears to Edgar Marwick as a death demon, or ghost - either of the drowned Lucy, or his mother, whose drowning he suspects. The scene strongly recalls Edgar's and Kitty's confrontations with Mrs Marwick in chapters six and eight when, smiling, seemingly luminous, she has embodied silence, terror and death (pp. 75, 91). Miss Perez's performance is a travesty of balance in that it unites her (as the White Lady and water nymph) with Marwick (as would-be soldier and fire-raiser) - the former being comic, the latter tragic: "She was luminous, alive in her coffin. [Noel and Phil] pulled her out and her dry arms folded round their necks. She rattled, she chattered and seemed to laugh. [...] To Marwick, she came into being with the silence. Her bones were bright in the inky blackness. Nothing existed outside her. Slowly she opened her hands. Jerkily, possessively, raised her arms. She reached for him. Marwick screamed. (pp. 145-146)

In moving back almost to die, and forwards almost to live, Mrs Marwick and Miss Perez parody what wholeness means to Gee. Paradoxically their individual asymmetry 
and movement contributes to the novel's brilliant symmetries and stillness. Through creating two such opposed figures Gee strives for an authorial balance that involves poking fun at his more serious concerns. At the same time he warns of the dangers of a sentimentalised approach to art and life.

\section{Literary Allusions}

That The Fire-Raiser is suffused with allusions to music and literature emphasises Gee's effort to balance war. Literature has various functions in the novel. Most obviously, it informs Gee's construction of characters. Gee has acknowledged Miss Havisham in Great Expectations as a partial source for Mrs Marwick. Certainly Dickens' aged spinster, betrayed on her wedding eve and dwelling in the past, is recalled in Mrs Marwick who wallows in sentimental dreams of love. As Gee has explained: "If [Mrs Marwick] has a parallel, and if she goes back to somebody, it's the woman in Great Expectations - Miss Havisham. There's a slight likeness to the way she grabs the girl and has her play the piano to Pip [... ] walking into the room, the wedding room". ${ }^{26}$

Other allusions to literature enter the novel largely through Wix and Hedges, both of whom are widely read. Gee balances the two against each other and through their allusions tells us much about their personalities and perceptions. In chapter one the sheer disparateness, fragmentation, and speed of the quotations that come tumbling out of Wix, whilst evidence of liveliness and ready wit, also imply a lack of peace: "The baker was wearing an apron and white cap, a costume that made him play the clown for his children. He was a brisk, plump man, given to snorts and whistles and exclamations of mock woe. Quotations bubbled from him, apt, inapt, and comic verse, or tragic verse given a comic inflexion" (p. 11).

Wix's mental movements match his physical movements. He hops from selfdeprecation to ironic self-mythologising in the same manner that he hops from oven to bench and that "his tongue [cannot] be still and [seems] to bounce along in time with his hands, always busy" (p. 11). Comparing his baking to Belloc's "Newdigate Poem" ("A smell of burning fills the startled air", p. 12), he then ironically parallels himself to Christ feeding the multitudes by the Sea of Galilee ("Bring your basket. You too, Kit, or else the multitudes will not be fed", p. 12). After playing doctor, and Lobster in Carroll's Alice in Wonderland ("He tapped a loaf with his forefinger and listened like a doctor listening to a chest. 'You have baked me too brown, I must sugar my hair"', p. 12), he parrots Uriah Heap's “umble” (p. 12) from Dickens' David Copperfield. He then 
concludes with a line from Longfellow's prose poem Hyperion ("Who ne'er the mournful midnight hours") that is finished by Kitty ("Weeping on his bed has sate", p. 12).

Against the bakery and the comic Wix who aspires to baking good bread, Gee sets the classroom and the more serious Hedges who aspires to composing a good poem. But as a teacher, Hedges cannot create a literary text just as Lotte cannot compose a musical one. His attempt at poetry is contrived and feeble: "The brain is a hive with millions of bees, and your body is a garden full of flowers, a farm with clover and buttercups ... No, no, mustn't get poetic" (p. 24). In fact, Hedges achieves a more truly poetic form when spontaneous as he is in chapter two beside Buck's Hole. There, his epiphany (previously quoted) suggests he is the creative artist who closely resembles Gee.

Counterpointing Wix's “mournful midnight hours" Hedges' allusion to the song "Hark hark the lark" from Cymbeline focuses on Heaven, morning and the sun (p. 21). But his allusions demonstrate a more wicked wit as, in comic Gothic manner drawn to death and mystery, he creates several literary identities for his asexual skeleton. Addressing it as goddess of the moon from Keats' Endymion and mock worshipping her, he claims, "Her loveliness increases" (p. 24), thus adapting part of the poem's second line:

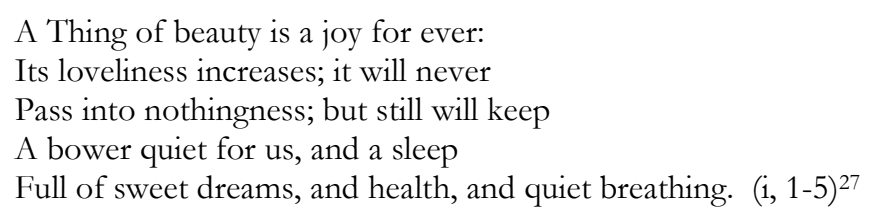

And by giving the skeleton the persona of Captain Nemo from Verne's Twenty Thousand Leagues Under the Sea, Hedges mockingly worships and thus disconcerts Mrs Bolton: ${ }^{28}$ “'Ah, Mrs Bolton. Captain Nemo welcomes you aboard.' He pulled a lever and the skeleton's hand came up in a wide-fingered salute. [...] 'Perhaps you and [Reverend Wilmott] would like to count the Captain's ribs?”' (p. 25).

Where Wix seems at the mercy of his comic wit, Hedges uses his wit to mock others (himself included). But behind Wix and Hedges stands the author who strives to integrate literary allusions with the novel's themes. Wix's repetition of Belloc's "A smell of burning fills the startled air" (p. 12) relates to the bread baking in his oven, and also Marwick's concurrent burning of Dargie's stables with their "oven doors" (p. 12). Similarly, the quotation from Hyperion depicting the fulfilment of the romantic imagination through fragmentation and death, comments ironically on the fragmented Marwick who at that moment is expressing his imagination in arson. The epigraph (from which Wix's quotation 
is taken) suggesting heaven may be known through darkness and sorrow, emphasises that, although experiencing these, Marwick will never know heaven:

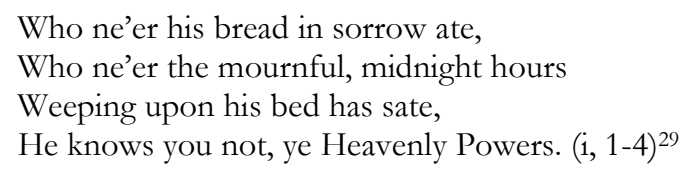

Hedges' allusions to Keats' Endymion and its moon (emblematic of mystery and mutability) and Verne's Nemo (Latin for no-one) also make manifest death and the incomplete that are represented in the asymmetric, unfulfilled Marwicks.

Phil and Kitty acquire a love of literature from Wix and Hedges, against whose comic forays Gee sets their more earnest imaginative escapes, thus providing a further parallel to war's motifs. Phil appears to see Jessop as a fortress-prison. In chapter seven, imagining escape by sea, he remembers "a poem Clippy had read” (p. 77) - John Masefield's "Cargoes" (1902). He dreams that a freighter resembling a "Dirty British coaster with a salt-caked smoke-stack/Butting through the Channel in the mad March days" (p. 77) will take him to a better world.

In focusing on the third of Masefield's three stanzas, which describes the coaster's cargo of lead, iron and tin (as opposed to the first two stanzas which describe material wealth), Phil compares Jessop to Masefield's England: "Phil had been at the wharves, watching the pilot bring in a freighter. She was a tub with rust patches on her sides, and she made him think of a poem Clippy had read" (p. 77). Set in the early twentieth century during England's more industrial era, the third stanza of "Cargoes" (from which Phil quotes) depicts a coaster carrying utilitarian items from Tyne (the river on which the industrial centre of Newcastle stands) across the English Channel:

\footnotetext{
Dirty British coaster with a salt-caked smoke-stack, Butting through the Channel in the mad March days, With a cargo of Tyne coal, Road-rail, pig-lead, Firewood, iron-ware, and cheap tin-trays. $(11-15)^{30}$
}

As Phil realises, Jessop too has its "freighter butting at waves" (p. 77). However, it is not only Phil who contextualises his experiences, but implicitly also Gee, for Masefield's industrial England is reflected in Jessop with its waterways, madness (that of the Marwicks) and March setting.

Like Phil, Kitty uses literature as an escape. Locked in Mrs Marwick's cupboard in chapter nine, she survives partly by recalling a man in prison who recited Paradise Lost. Released, she asks Hedges, "Do you remember [... ] you told us about a man in prison for years, and [how] he recited all the poems he knew, all the long ones. . . ?’ Hedges responds: 
“Paradise Lost" (p. 100). The allusion contextualises Kitty's and, years earlier, Marwick's imprisonment in the cupboard. It also calls to mind Milton's fallen Satan (thought to be based on Milton's character), who further contextualises Marwick as similarly "fallen" and associated with fire and flight. In chapter one Satan's fiery furnace in Hell is echoed in Marwick's “furnace” (p. 10) - the fire in Dargie's stables: "The double doors were wide, like oven doors, and from inside came a flickering like a magic-lantern show" (p. 12). Milton's Satan as a "flying fiend" (ii, 643) and "vulture" (iii, 431) is recalled when, leaving the bakery, Kitty sees a "thing that flapped and loomed like a huge black bird [with a] vulture skull" (p. 13). ${ }^{31}$ And in chapter twelve Marwick appears blown into life by Satanic forces: "Marwick seemed to climb out of a pit. Again the ember-glow of his head, as though brought alive by someone blowing" (p. 142). Inhabited by this "Satan", permeated with smoke and fire, the fallen Jessop becomes a version of a Paradise that is lost.

\section{The Larger Significance of Literary Allusions}

In contextualising Jessop's characters and events, literary allusions bring to them a larger significance. Gee appears to invite both child characters and the reader to explore their sources. In fact, Verne's Nemo recalls the sea captain as would-be artist, gothic, vengeful and destructive, who colonises and exploits an oceanic underworld, and wars on society. Thus ironically contextualised is the gothic, would-be artist Marwick, who is vengeful and destructive, who makes Jessop an underworld, and wars on society. That the logical, ordered Hedges (an aspiring writer) is fascinated by Nemo may equate him to the logical, ordered Dr Aronnax (narrator and effectively writer of Verne's novel). Indeed, Hedges is attracted to Marwick in much the same way that Aronnax is attracted to Nemo, for Marwick and Nemo represent the gothic that Hedges and Aronnax are drawn to and that, at least superficially, they are not.

Like allusions to history and historical texts (the Gibbs material, Gee's school story, and the pageant, for example), literary allusions lead to sources that enable a fuller understanding of the novel as part of a larger whole. We find upon returning to Hyperion that, having risen to the textual surface when quoted by Wix, the poem then operates implicitly to inform Gee's depiction of Jessop.

Jessop thus recalls the gothic landscape of Hyperion, with its rivers, castles, ruins, denizens, and giants. A river surrounds the Marwicks" house, a crumbling "faery castle" (p. 34) in which live threatening "denizens" (p. 34), the Miller house has "dents as though a giant had punched it" (p. 51), and the Marwicks appear as giants to Irene and Kitty in chapters seven and eight (pp. 82, 88). The numerous chimes from clocks and 
bells in belfries, towers and churches that mark Paul Fleming's route through Europe, are echoed in Jessop's chimes: the Post Office clock, the Marwicks' clocks, and the school belfry's bell. The prose poem's burning night lamps are recalled in Jessop's gas lamps that cast a fragmented light at night (pp. 8, 67, 141). And the night "like a fathomless, black gulf, into which the spirit plunges, floats" in Hyperion is echoed in Jessop's liquid darkness spreading "like water through the town" (p.137). ${ }^{32}$ Similarly the prose poem's broken moonlight is recalled in Jessop's moon as "a blade" (p. 71), and "a huge half' (p. 103). Where the midnight hours in Hyperion herald supernatural events, Jessop's midnight hours herald Marwick's escapades, as Wix's allusion to “mournful midnight hours" (p. 12) suggests. Where the German night resounds with a tumult, a brawl, and a fire-alarm, at night Jessop, too, experiences chaos, fires and fire alarms (pp. $10,14,70)$.

Like Longfellow's gothic Europe (or that of Goethe), Jessop has its summery daytime side, conveyed largely through Hedges (p. 20). ${ }^{33}$ In creating his "poem" in chapter two, Hedges (and Gee) seem to appropriate the very images of Longfellow's prose poem. Hyperion reads: "Yellow butter-cups stud the green carpet like golden buttons, and the red blossoms of the clover [are] like rubies. [ . . ] The bee only is at work". ${ }^{34}$ As we have seen, Hedges' "poem" includes bees, clovers, and buttercups (p. 24). But like the landscape in Hyperion Jessop has a stronger sense of the supernatural. Recalling Fleming's acquaintance with "Walpurgis Night" in Goethe's Faust, the German Lotte compares the pageant's riot to "Walpurgisnacht - Witches' sabbath" (p. 123). Indeed, the giants, dwarves, witches, hags, devils, magical creatures, and "White Lady" encountered in Hyperion are recalled in The Fire-Raiser which has its magical and demonic creatures and White Lady.

In extending characters' allusions to literature, Gee establishes a reciprocity between their sources and the novel. Extraneous texts mirror and are mirrored by Jessop. Moreover, Jessop reflects an older Europe and the gothic imagination. We turn now to archetypes associated with these.

\section{Fairy Tales}

Fairy tales colour characters' views. As noted, in chapter eight Kitty sees the Marwicks' décor in terms of giants, castles and gothic landscape. When angry, Irene appears to Kitty "like Rumpelstiltskin" (p. 45). To Phil, Noel in Buck's Hole is “as short as a dwarf" (p. 37). And to Irene in chapter seven, her escaping friends resemble "three galloping dwarfs" (p. 81). 
In moments of intense emotion, fairy tale archetypes are less explicit. In chapter seven, escaping the giant-like Marwick, Irene does not identify him. Instead she sees him impressionistically in simile and metaphor. Indeed, the image of Marwick as giant evolves from a source beyond reality, as Gee through Irene suggests:

\begin{abstract}
Now, as he grew taller crossing the paddock, as his boots ate up the land, he was like someone from a nightmare. He was magical, terrifying; [ . . . Irene was used to managing adults, but knew that here was one she would never control. It was like being shown that beyond grownups was another group of beings, magical and powerful and not to be approached. (p. 82)
\end{abstract}

In chapter one figurative language accompanies Marwick's dreamlike revelry, and his projection of archetypes onto the surroundings seems to rise from an infantile mentality that was his at age ten (when imprisoned). The disparate fragments reflect a truncated knowledge of society's fairy tales and his mental imbalance, for characters vaguely recognisable as Rumpelstiltskin, fairy godmother, and Prometheus are unnamed and largely unformed. In playing their parts Marwick believes he can turn base matter into gold, bestow a precious gift, bring fire to mankind, wake the sleeping or dead, and imbue darkness with beauty and light. The scene embodies his compensatory illusions of grandeur and magical power:

Light from the gas lamp outside Wix's bakery [... ] made the grain sacks gleam like fat gold ingots and the straw on the floor like golden thread. [ . . ] Outrage, power, pleasure, were important.

[...] Matches were magical to him and full of secret whispers and promises. He scratched [a match] on the box and flame sprang out. The red balaclava bloomed like a rose. He let the matchstick burn, knowing the power in his hand, and when the flame had nothing more to feed on, thrust it like a gift into the hay. Flame filled the inside of his head. It ran along his arteries. It licked around his bones. He gave a whinnying scream, like a horse, and capered in a dance, swimming in the red and yellow light. Then he seized a torch of hay and leaped with it flaming in his hand, with his black coat flapping, down to the hay pile in the shed, and rolled in it, setting it on fire, and ran along the wall, touching things as though with a wand, waking them up. (pp. 8-9)

Marwick's repeated projection of his delusions onto the external scene resembles an orgy. Depicted in terms of bodily functions, it suggests his self-obsession. He consumes and is consumed by fire: "Flame [fills] the inside of his head [runs] along his arteries [and licks] around his bones" (p. 9); "He had a full, fat smile on his face. He would not need another fire for a while now. This one sat inside him like a meal. He would lie in his bed and digest it" (p. 16). Spinning megalomaniacal fantasies that in turn possess him, Marwick can be seen as a collective personification of the worst side of characters in Jessop. 
Gee matches Marwick as archetypal giant/devil with his mother as archetypal witch, old mother and wicked queen (thus fusing imagery of fairy tale and empire). Mrs Marwick imprisons children in a cupboard (recalling Old Mother Hubbard, and the evil stepmother and witch in Hansel and Gretel). And she also threatens with a stick that resembles ferrule, wand and sceptre: "She sat before [Hedges and the children] like a queen, an ancient, dry-boned, beak-nosed queen, and held her stick across her knees as though she might suddenly point and order someone's death" (p. 71). Certainly, at the end of chapter six Mrs Marwick resembles the wicked witch or queen others have imagined her to be:

'Come here, Edgar. Sit down.' She tapped the sofa with her stick.

He disobeyed. Things revolved about her. They fell into the places she chose for them. He would not do it. He moved about the room.

$[\ldots]$ She put her stick on his shoulder and held him still. $[\ldots]$

She watched him, the hulking man who had never grown into a man. Then she tapped him with the ferrule of her stick and pushed him away. (pp. 74-75)

For balance to occur in Jessop, Hedges must control and hold Marwick still which he does when he defeats Marwick in an archetypal battle between hero/thumbkin/dwarf and giant: "Hedges hit him with his left again, stood Marwick still, and crossed a short punch with his right and knocked him down. Marwick lay stunned on the grass” (p. 130). The victory marks a turning point. For it is the ugly Hedges as a comic knight or saviourhero who then rescues Mrs Marwick as tragic queen or drowning diva, to take Marwick's place at her side. His kneeling posture and hooked fingers subtly recall Marwick's kneeling before his mother in chapter six and earlier salute. However, it is not a kiss that wakes her from sleeping, but artificial respiration: "Hedges knelt beside Mrs Marwick. He hooked his finger in her mouth and brought her false teeth out. [ ... ] He put her head on one side, made sure her tongue was clear, and started artificial respiration" (p. 132). And in chapter twelve it is Marwick as archetypal lost child who must confront Hedges' skeleton as White Lady and death demon: "Big man though he was, he seemed as small as a child. [Kitty and Irene] saw his wet cheeks and trembling mouth. His eyes saw nothing; they seemed blind" (pp. 146-147).

In another brilliant reversal, the exchange of roles by Mrs Marwick and Hedges' skeleton is exactly matched by Marwick and Hedges. Marwick reverts to the child he was years earlier when, shut in the cupboard, he became blind. And Hedges as wise hero occupies a central position within the previously distressed system of children who, now calm and symmetrically arranged, surround him in an image of balance: "[He] put his 
arms round the girls' shoulders. [.. . ] They went down the steps, Hedges, Irene, Kitty, with Noel on one side and Phil on the other" (p. 147).

Finally, then, Jessop becomes emblematic of a deeper imaginative, even magical reality that recalls the myth or symbol that Ellie sees as allowing "people to communicate on a deeper level" (p. 307), and as holding characters still in Ellie and the Shadow Man. ${ }^{35}$ The Marwicks are tragic individuals, but also symbols of evil. Hedges is a mixed individual, but also a symbol of good. As symbols they are effectively held still by Gee whilst as actants they play active roles in forming Gee's narrative. Projecting negative roles from literature onto others, they must bear some responsibility for their own and others' fate. That they fuse with Gee in constructing the story suggests Gee's harmony with his characters and technical balance.

\section{Intertextuality}

That so many of Gee's allusions are to texts depicting ancient stories of love and war, extends the novel as part of a larger historic and literary whole. For example, in Shakespeare's Cymbeline "Hark hark the lark" is actually sung for the purpose of immoral seduction for political gain during the ancient Roman and Briton wars. Similarly, in chapter eleven Wix's joking quotation from Troilus and Cressida ("O! when degree is shaked", p. 123) recalls Ulysses' speech during the Greek and Trojan war. Both plays blend ancient real and fictitious wars together.

In chapter nine Hedges' reference to Orpheus, and Mars and Venus as "planet of war, planet of mystery and love" (p. 104) extends the novel's mythical context. For Gee seems to create parallels between the novel's characters and those of legend and myth. For instance, Hedges - an aspiring poet, lover of music and teacher - appears to identify with Orpheus, the beautiful young poet, musician and teacher of Greek legend. Similarly, Marwick can be seen as a version of Mars, linked as he is to Mars by his name, aggression and red balaclava. (Mars is commonly described as a red planet.) These parallels are, of course, ironic. In chapter two Hedges' quotation from Endymion recalls the romantic young shepherd who is in love with the beautiful moon, but in the ugly middleaged Hedges and his skeleton we have the very opposite.

Indeed, in chapter nine Jessop's "huge half moon" is "strange, almost terrifying (p. 103). Seen by Phil as "pale as marble and smudged with grey" (p. 103) it contextualises the flawed Marwicks when he then points the telescope down on them to see them within this cosmic context. Contrasting to the shepherd Endymion's moon and Hedges' allusion to it, the Marwicks more closely parallel Jessop's gothic moon 
which terrifies Phil with the enormity it suggests: "It became terrifying. Its size was overwhelming, and a weight seemed to crush on [Phil]" (p. 103). Finally, then, the fictional lunar fragment of chapter two encourages an exploration of a body of literary knowledge, whilst the real lunar fragment of chapter nine suggests the abyss that is reflected in the Marwicks in their very lunacy.

Whilst acknowledging the abyss, Gee seems to balance it and build a resonance by alluding to texts that in turn allude to ancient history and myth. The first stanza of "Cargoes" depicts a mythical journey from "distant Ophir" to Palestine's Nineveh (Biblical capital of the Assyrian Empire, and located on the Tigris). As Verne's Nemo and Aronnax travel beneath the Red Sea, through the Arabian Tunnel, and around the Greek Islands and Mediterranean, they cover the same ancient geographical and imaginative territory. Milton's Paradise Lost parallels the civil wars of Heaven and England to those of Biblical and Classical mythology, and therefore covers similar grounds. Set on Mount Latmos (the gods' home in Thessaly), Endymion also refers to the ancient classical world and myth, as does Troilus and Cressida, set on the battlefields of Greece and Troy.

Gee thus lodges his novel within layers of real and fictitious history, and a universal body of human knowledge. That many of the Biblical and Classical locations mentioned in Paradise Lost are the very sites of World War I's battles paralleled in Jessop, increases Jessop's resonance. To give but a few examples: Milton describes Satan in flight experiencing more dangers than Argo passing through the Bosphorus, and Ulysses shunning Charybdis, a whirlpool in the Straits of Messina (ii, 1017-1020). ${ }^{36}$ Parallels therefore occur between these events and locations, 1915's real war in the Bosphorus, the war in Jessop over the water holes, and Lucy's and her mother's drowning and near drowning in them. The advice of Milton's Adam and Eve to all "living souls" through singing "up to heaven gate ascend" (v, 197-198) is paralleled in Shakespeare's "Song" in Cymbeline (II, iii, 20) and in Jessop when Hedges' class sings the song: "Hark hark the lark at Heaven's gate sings" (p. 21). ${ }^{37}$ Milton compares Sin's and Death's passage between Earth, Chaos and Hell to the bridging of the Hellespont, on the tip of the Gallipoli Peninsula, by King Xerxes of Persia in 480 BC, thus opening a route for the invasion of Greece (x, 304-311). ${ }^{38}$ Parallels occur between these routes, the Dardanelles in 1915, the wars in Jessop over the waterholes, and the real future battle of the Anzacs at Gallipoli. Consistent allusions to texts covering the same geographical and imaginative territories mean that interconnections (too numerous to cover in detail) exist between these texts, and provide a stabilising force, and perhaps also a reassurance for the reader, against the abyss and the lunatic Marwicks. 


\section{Conclusion}

Taken together, allusions work implicitly to make Jessop a microcosm of worlds that are modern and ancient; historical and fictitious; and real and imagined. The Fire-Raiser takes its fullest meaning from the contexts and texts that surround it, whose traits echoing across vast distances appear within it. ${ }^{39}$ The novel thus seems to be a full, solid world that spins in tandem with the worlds it mirrors and that mirror it, and yet it is held still by these worlds. Gee therefore contributes to a wholeness extending far beyond the novel. As he has commented: "I wanted to get away from the novel enclosed in itself and write something that overflowed, that connected with life outside the pages. I wanted to blur the margins between the fictional and real worlds. I wanted to put in, not leave out, suggest fullness not emptiness, present a coloured world not a grey one. I wanted engagement not withdrawal". ${ }^{40}$ Gee triumphantly achieves these aims in The Fire-Raiser. 


\section{CHAPTER 4}

\section{The Champion}

\section{Introduction}

Following the publication of The Fire-Raiser in 1986, Gee's next realistic novel for children was The Champion. Published in 1989, it depicts a changing New Zealand that embraces not only British but also American culture. As though to cover the range of New Zealand history, Gee seems to set the two novels against each other. Where The Fire-Raiser takes place during World War I and portrays the eponymous Marwick as upper class, white, English and a villain, The Champion takes place during World War II and portrays Jack as working class, black, American, and a hero. Where the four children in The Fire-Raiser are forces of good that offset Marwick as a force of evil, Rex in The Champion behaves in an evil way and offsets Jack who represents good. In The Fire-Raiser the four children operate mostly separate to the childlike, warring Marwick, but in The Champion the symmetry of four includes three warring children and also the childlike, pacifist Jack. And where the middle-aged Marwick represents society's ignorant and dark side and Jessop resembles an underworld, the twenty-year-old Jack represents society's wise side and Kettle Creek resembles Paradise.

\section{The Social Climate in New Zealand: 1960s to 1980s}

As we have seen, Gee's deliberate setting of The Fire-Raiser just prior to the battle of Gallipoli makes the novel seem prophetic. The influence on Gee of contemporary history allows The Champion, too, to seem prophetic. New Zealand's pacifist movement of the 1960 s to 1980 s seems to have conditioned Gee's attitudes. Thus within the novel's World War II timeframe, he depicts a predominantly peaceful world.

In 1989, when the novel was first published, New Zealand had been undergoing a social revolution. What Michael King has described as a "mutating lifestyle" reflected civil rights and anti-war movements in the United States and resulted in a counterculture. ${ }^{1}$ The obsession with security following two world wars and a depression was replaced with a freeing up of belief systems. Many of the generation of post war babies (or "baby boomers"), reacting against institutionalization, adopted a relaxed lifestyle. Some adhered to the principle of "make love not war", and advocated free sex, drugs, and longer drinking hours. Hair was worn longer, clothing became more colourful, and 
personal dirtiness and dishevelment were considered "natural". Sometimes dubbed "Hippies", such folk valued the rural life, simple things, and communal work or living.

An important part of the counter-culture, the women's movement advocated the contraceptive pill which, freeing women from unwanted pregnancies, allowed them careers. Some sought equality with the opposite sex, particularly in employment opportunities. Socialist values - pacifism, co-operation, communality, tolerance, equality and respect for the environment - were reflected politically with the formation of the leftwing Values party.

\section{The Novel}

Gee has referred to himself as "an old socialist [...] an unreconstructed socialist [who is only] reconstructed to a certain extent" and has stated that conservationist, antipollution and anti-nuclear messages "are just coming from the outside a little bit and colour the story and provide little plot things to go on with". ${ }^{2}$ Doubtless, the increasingly liberal climate of New Zealand in the 1960s to 1980s influenced The Champion's plot. Indeed, Jack seems to love what are effectively "pre-hippie" aspects of Kettle Creek life that are most obviously epitomised by Rex's grandparents. Kettle Creek's rural lifestyle greatly contrasts to Jack's urban background in Chicago. It provides him with communality and proximity to nature and causes him to claim it is "the best thing that ever happened to me" (p. 150). ${ }^{3}$ Friendly, laconic, and peace-loving, Jack, had he lived in the 1960s to 1980s, would certainly have echoed the counterculture's ideal of "make love not war". Within the potentially fraught quartet of himself and the three children, he is the harmonising factor who provides balance and encourages mutual respect.

In adapting to life at Kettle Creek, Jack is assisted by Grandma Crombie, the strongly feminine, maternal "earth mother" - an archetype associated with fertility, fruitfulness, the earth, and garden. ${ }^{4}$ A veritable "hippie", Grandma cultivates the land, makes parsnip wine, sunbathes naked, and communes with nature. She also adopts a free style of clothing and hair, and displays a loving kindness to all. In chapter five Rex describes her seemingly hippie-style clothing: "Her dress was one of her old baggy multi-coloured ones. [...] She wore laceless sandshoes with her big toes breaking out and a tennis sun-visor casting green light on her face. Her long white hair hung down her back" (p. 62).

Whilst credible for the 1940s, Grandma Crombie also seems to anticipate the feminists of the 1960s to 1980s. Not only does she care for Dawn when her 
grandmother dies, but she also has a strength of purpose traditionally associated with masculinity. She governs her husband Freddie, seeks out Jack when he goes AWOL, and rides a motorbike. Embittered, and resisting motherhood and maternity to become predominantly masculine, Dawn's grandmother Mrs Stewart is the antithesis of Grandma Crombie.

\section{Racial Issues in New Zealand: 1940s to 1980s}

Contributing to ideals of brotherhood, equity and peace in The Champion, and thus working against the 1940s theme of war, may have been the changing attitudes to race seen in New Zealand in the 1960s to 1980s. According to King, after years of belief in the Pakeha myth that "New Zealand had the best race relations in the world" and that the Treaty of Waitangi was "the fairest treaty ever made by Europeans with a native race", Maori began to ask questions. ${ }^{5}$ Notions of an "integration" or "assimilation", effectively meaning Maori had to adapt to English language and customs, were criticised. Reacting against discrimination, loss of land and the decline in Maori language that had occurred with urbanisation and lessening links to iwi and hapu, Maori activists gained increasing media attention. Liberal Pakeha, as part of the counterculture developing more humane attitudes towards ethnicity, supported them. Gradually in education and some state institutions there was eventually a recognition of ethnic diversity and a growing commitment to bi-culturalism and multi-culturalism. ${ }^{6}$

In October 1975, following Dame Whina Cooper's historic consciousness-raising hikoi, Parliament passed a bill establishing the Waitangi Tribunal to settle land claims related to the 1840 Treaty of Waitangi. In 1981 liberals, both Pakeha and Maori, united in protest over the controversial tour by South Africa's segregated rugby team, the Springboks. ${ }^{7}$ In 1987 the Maori Language Act was passed in Parliament, making New Zealand officially bi-lingual. However, in 1985 it was the Waitangi Tribunal that was responsible for changing the cultural climate completely. As King has noted, "its powers were made retrospective to 1840 [and] it was one of a series of measures which so changed the face of New Zealand life in the 1980s and 1990s that their cumulative effect could legitimately be called a revolution". ${ }^{8}$

In The Champion Gee apparently sets the 1960s to 1980s ideology of racial equity against the racial discrimination typifying the 1940s when New Zealand was closely allied to Great Britain. As well as using English language and customs, New Zealand, of course, had a population largely of British ancestry. King has commented: "The dominant cultural identification [ . . . ] was still 'British', a continuing reflection of the 
fact that, for more than 95 per cent of the non-Maori population, their countries of origin were England, Scotland, Ireland and Wales". Noting how proud New Zealanders were of their British nationality, King goes on to quote Lord Jellicoe (Governor-General in 1924) who reputedly said that New Zealanders claimed "to be even more British than their kin of the Motherland". Many New Zealanders defined themselves as British. As King records, in opposition to the 1931 Statute of Westminster, which granted the dominions autonomy, one National MP stated that "he would rather be a British subject than a "national of the British Commonwealth". And King also notes that the "obverse side to this confidence in racial and cultural identity [...] was a fear and dislike of nations and cultures that were not British. Such a fear was at times xenophobic". Thus, King claims, non-English Europeans were regarded with suspicion, including the Chinese, Indians, Dalmatians, Lebanese, and Jews. ${ }^{9}$

As a child growing up in Henderson in the 1940s, Gee seems to have been conscious of its ethnicities, which included a significant population of immigrant viticulturists from Europe and the Mediterranean. Among these were the Yukich family who cleared the land and planted grape vines. Those of British ancestry categorised the Yukich family and other non-British immigrants collectively as "Dalmatians". As Gee has recalled, “the Dalmatians were called 'dallies' or 'squareheads' [and] there was a good deal of feeling round Henderson during the war that they were grabbing land while our boys were away". ${ }^{10}$

During the 1940s there was also much discrimination against Maori, particularly in 1943 with the presence in New Zealand of American marines training for war. Lorain Day and Tim Plant have described how those from the South apparently treated New Zealand Maori as they treated black Americans, calling them “"niggers' and other derogatory names", and how in Wellington in April 1943 American sailors fought Maori:

\footnotetext{
The Battle of Manners Street was [ . . ] notorious. It began around 6 p.m. in the Allied Services Club on Manners Street. Some marines objected to sharing the bar with Maori, and a fight broke out. The marines allegedly used belts weighted with heavy metal buckles, and New Zealand servicemen retaliated with fists. Around 8 p.m. the fight moved into the street, where the crowd joined in. Fights erupted everywhere - as one was suppressed another began, with over 1000 men involved. ${ }^{11}$
}

\section{The Novel}

The more racially aware period of 1980 s New Zealand is certainly reflected in The Champion, but so too is the reality of racial prejudice in the 1940s. Gee sets the two against each other, apparently to generate tension and encourage in the child reader more positive values. 
Gee seems to suggest wholeness by referring to a diverse range of ethnicities, including Dalmatian, American, British, Japanese, German, and of course Maori. He reveals his own anti-racism in his sympathetic, unromantic portrayals of Leo the Dalmatian boy, Dawn the Maori girl, and Rose's dead Maori fiancé (Jimmy). Indeed, he depicts them as real people with both good points and flaws, who are individuals, yet aware of their racial identities. An African American, Jack, of course, is an extremely sympathetic, likeable character who becomes Rex's "champion". Nevertheless he is fallible and, as Rex realises when Jack goes AWOL, he is cowardly. But his fallibility is not attributed to his racial identity. Whilst we are required by Gee to understand the racial discrimination that has made Jack as he is, we nevertheless realise that Jack must share responsibility for his fate.

Against anti-racism and pacifism Gee sets the racial prejudices evidently typifying 1943, when the novel is set. Echoing Gee's recollection of Henderson during World War II, the school teacher Miss Betts refers to "our boys" (p. 23) and describes Dalmatians as "squareheads" who are "pinching land while the soldiers are away" (p. 25). As Rex ironically points out, by "our boys" Miss Betts means "a New Zealand boy, a British boy" (p. 23). Equally prejudiced, Rex describes Dawn Stewart as "barmy" and "only a Maori” (p. 35), Tojo (the Japanese General) as a "yellow dog" (p. 9), and Jack as "Private Monkeyface" (p. 40). Rex's naming of Leo as "a Dally" and a "squarehead" (p. 23) recalls the historic non-British immigrants, collectively called "Dalmatians". As Leo later explains to Jack, "I'm really Croatian [ . . . ] but they call us Dallies" (p. 56).

The importance of race is emphasised by Rex's ignorance of "race", apparent in his belief that The Maori Race (Elsdon Best's book about Maori in the 1800s) refers to running (p. 8). Most prejudiced are American soldiers, Marvin Varcoe and Herb Cutter, who are Southerners and who term Bob Davies (the Maori policeman) and Jack “nigras" (pp. 29, 99). Towards them Marv and Herb demonstrate an aggression that recalls the white Americans' treatment of blacks in the Manner Street brawl of 1943. Overall, therefore, the novel embodies 1980s anti-assimilationism whilst accurately portraying a 1940s reality, and so provides a corrective to the racism occurring historically.

\section{Small Town New Zealand during World War II}

Gee depicts pacifism versus racial prejudice and war as he experienced them as a child in Henderson, New Zealand during World War II. In 1943 he was a twelve-year-old living with his two brothers, a poetry-writing mother and a carpenter father (who was 
also a boxer). With only a bus link to Auckland, Henderson was cut off from the wider world. Gee has recalled how he and his family "used to have to drive through farms to get to Auckland", and the landscape around Henderson as "Edenic". He and his friends would go "fishing, eeling, swimming, canoeing and exploring in the mangroves in the upper reaches of the Waitemata Harbour". As "a country town of vineyards and orchards", Henderson indeed seems to have been an Eden. ${ }^{12}$ Amongst the region's viticulturalists were Dalmatians Mate and Frank Yukich, who in photographs appear large and strong. ${ }^{13}$ Gee himself has recalled Henderson's orchards and the Dalmatian wineries. ${ }^{14}$ But in the 1940s the insularity of Henderson, and indeed New Zealand, was challenged. In $1943 \mathrm{New}$ Zealand soldiers were fighting for the Allied cause in Europe and the Middle East, the Japanese had bombed Pearl Harbour and were moving south towards the Solomons, and the American marines were in New Zealand training for war in the Pacific.

Gee himself was fiercely patriotic. A school cadet, he witnessed "the flag [that] was raised each day at school", and was a "goody [...] prissy child [with] a good deal of the puritan" in him. ${ }^{15}$ He was also part of "a two-man purity squad" clearing the playground of those who swore or dissented, and a member of gangs named Army, Navy, and Airforce. ${ }^{16}$ Gee has recalled, moreover, reading The Champion, a weekly comic for boys and the enormous influence on him of one its heroes, a pilot with the RAF: "The Champion played a large role in my life. [...] I think it was my first real reading. [... I I was devoted to Rockfist Rogan of The Champion. He was a great hero of mine. Each week he'd shoot down a few Messerschmidts and have a boxing match". Gee imagined fighting the war: "We used to play violently anti-Japanese and anti-German games. I can remember quite plainly how I used to get old cardboard boxes and burn them out in the back yard. I used to imagine this was Hitler in his palace and I'd watch as the flames crept from room to room till there was only the last little corner of cardboard box and Hitler was in there". Indeed, Gee has recalled BB guns, the reality of the Japanese threat, and his father on Manpower building gun emplacements to keep the Japanese out.

Gee and his friends came to know the war in a more real way through making the acquaintance of American servicemen frequenting Henderson for its wine, as he has noted: "There were a good number of Americans coming in and out of our house during the war. Henderson, being a wine-growing area, attracted a lot. A constant stream of jeeps came in - American GIs and their girlfriends. We used to hang around cadging gum and candy and we spied on them - hoping to learn a bit about sex - as they picnicked down at Falls Park". ${ }^{17}$ 


\section{The Novel}

Gee includes much personal and factual information in the novel. Like the young Maurice, Rex Pascoe, a twelve-year-old boy, lives with a poetry-writing mother and a father who boxes. Like Henderson, Kettle Creek is cut off from the wider world and is cultivated in vineyards and orchards. Rex notes it is "thirty-five miles from Auckland along a metalled road", and adds: "Standing in the hills, on clay tracks cut from gorse, you could see the twice-daily bus coming from miles away through the farms" (p. 18). The real Dalmatian Yukich viticulturalists also have a presence in the novel. For the adult Rex recalls that "Stipan Yukich, coming down from the north in the twenties, had bought [the scrub-covered famland] cheap and cleared it and planted vines" (p. 31). The young Rex is friendly with the Yukich family, especially Leo, whilst his sister Gloria is engaged to Leo's brother Matty. In chapter three, meeting Stipan Yukich for the first time, Rex is "awed by his size" and notes, "My hand in his was like a matchbox in a builder's clamp" (p. 32). Recalling Gee's childhood adventures, Leo and Rex go canoeing in the creek and mangrove swamps. The adult narrator comments: "I can't imagine growing up without those [ ... ] three things - mud, mangroves, warm brown tidal water" (p. 18).

Although cut off from Auckland and the wider world, war is a real presence in Kettle Creek. At school Rex is "NCO of the school cadets" and, in charge of a platoon, drills the children and shouts "Left wheel, right wheel, shoulder arms, present arms, attention, stand at ease" (p. 21). Fiercely patriotic, he performs as part of the honour guard for the daily routine of raising the school's Union Jack following which the children sing "God Save the King" and march into the classrooms to the "Colonel Bogey March" (p. 23).

Like the young Gee, Rex enjoys reading The Champion and his biggest hero is Rockfist Rogan of the RAF: "I went to my bedroom and pulled on my clothes, reading my Champion at the same time. This was a boys' weekly that came from England and sold for fourpence. [...] I was in the middle of a story about Rockfist luring the Hun ace into a fight by pretending his Spitfire was crippled" (p. 10). Again like Gee, Rex plays violent anti-Japanese and anti-German games: "I was out on the back lawn in my

pyjamas shooting Hitler and Tojo with my BB gun. [...] Standing on the back gravel I shot Hitler and Tojo from a distance of twenty feet until only tatters of them were left" (pp. 8-9). 
Rex and his friends learn about war directly through the presence in Kettle Creek of American GIs. These include Marvin Varcoe, Herb Cutter, Rose's boyfriend Stan Paretsky, and Jackson Coop who shares his gum and candy with Rex and Leo, and spends time in Rex's house. When Rose and Stan, together with Dawn, go off for an outing they travel by jeep and picnic by the river.

Thus Gee sets parts against each other and creates a tension between pacifism, and racial prejudice and war, as represented by an Edenic Kettle Creek, and features of World War II. Furthermore, he suggests that these encroach on each other. The barrier between Kettle Creek and the wider world breaks down as it did between Henderson and the wider world in the 1940s. Like the young Gee, Rex lives in a peaceful rural world but is prone to the influence of war.

\section{World War II in the Pacific}

Broadening out beyond Kettle Creek to war in the Pacific, Gee alludes to a larger reality. Following the bombing at Pearl Harbour, Japanese warplanes bombed and torpedoed the British battle cruiser Repulse, and HMS battleship Prince of Wales on 10 December 1941. They then took over much of the Pacific, including the Solomon Islands. One island, Guadalcanal, became a base for the Japanese who constructed the strategically important Henderson airfield.

However, in mid 1942 the United States took the offensive in the Pacific and in August 1942 American marines, divebombers, and F4F fighters invaded Guadalcanal. Within two weeks they took the area on which Henderson airfield was positioned. In September further marines landed to be reinforced in October by the $164^{\text {th }}$ infantry (the first army unit in Guadalcanal) and in December and early January by the 132nd Infantry, the XIV Corps, and the $25^{\text {th }}$ and $27^{\text {th }}$ Infantry Divisions.

But Guadalcanal's tropical climate, dense jungles, mountains, mud and swamps were problematic for the Americans. In New Georgia "shellfire in the swamps created gaping holes under the camouflage of floating weeds" in which a man could disappear. ${ }^{18}$ A coastline lacking natural harbours meant that amphibious landings were difficult whilst deep streams traversing the island inhibited movement. Living conditions were appalling with a diet limited to potatoes, Spam or cold hash, and rice, and only Japanese cigarettes to smoke. At night sleep was constantly interrupted by Japanese cruiser planes dropping bombs, or by shells from offshore destroyers and submarines. Evidently the Japanese also performed fanatical attacks whereby they would emerge from the jungles, screaming out "banzai", throwing grenades, and firing weapons. 
Nevertheless, the American marines' recapture of Henderson airfield was followed by further triumphs in September and October, including two battles fought on Bloody Ridge when marines and infantry consistently repulsed the Japanese. Finally, from 13 to 15 November 1942, the classic naval battle of Guadalcanal took place. It was the beginning of the Japanese retreat from the Pacific. Further battles in Kokumbona and on Grassy Knoll stretched from November through to New Year. But at the end of 1942 Japanese General Tojo conceded defeat and in early February 1943 the last Japanese survivors left the "Island of Death". Guadalcanal was finally declared secure on 9 February $1943 .^{19}$

\section{The Novel}

Gee incorporates into the novel features of the war in the Pacific and the Japanese threat to New Zealand. The novel's timeframe over two weeks of February 1943 coincides with the mood of relative safety prevailing in New Zealand following the final securing of Guadalcanal. In chapter one Rex considers the battles in the Pacific in 1942, and the current situation:

\footnotetext{
They came down the Pacific so fast, taking Singapore, which wasn't an American but a British place, and taking the islands one by one, and sinking the Repulse and the Prince of Wales. [...] But now, 1943, the danger was over, Tojo was stopped at Guadalcanal, he wasn't going to get to New Zealand. (p. 9)
}

With Jack's arrival at Kettle Creek, Rex becomes closely acquainted with war in the Pacific. Having been wounded in Guadalcanal, Jack gains respite with the Pascoes. His arrival in late February, service in the infantry, and fact that he bears a scar that has had time to heal, aptly fit with the timeframe of the fighting in Guadalcanal between 13 October (when the first army unit landed) through to the end of 1942. Recalling the soldiers who smoked Japanese cigarettes, and whose sleep was broken by bombs, shells, and banzaii attacks Jack is restless during his first night in Rex's bedroom. Rex notes that Jack "pulled the curtains open. [He] got into bed, propped the pillow up on the headboard, and lit a cigarette" (p. 44). Certainly Jack fears shellfire since he mistakes Alf s "ear-splitting whistle" for the "whistling sound of a shell" (p. 45).

Gee therefore constructs a credible version of the 1940s reality of war in New Zealand, but goes further than the literal incorporation of fact and genuine experiences. As Jack projects Guadalcanal's dangers onto the night-time landscape, the war seems to occur in Kettle Creek. With its dark "empty paddocks, the mangrove swamps, the silent water, and no-one to talk to [and] croaking of frogs" it causes Jack to recall that "there 
had been frogs in the Solomons [and] he didn't like the sound" (p. 141). Rex also perceives the landscape in terms of war in the Pacific. It therefore recalls Guadalcanal's jungles, swamps, streams, mud and dust, and Japanese presence:

\footnotetext{
We glided over the water [of the estuary] with shallow paddle strokes [... ] heading along the edge of the cliffs and past the fringes of the mangrove jungle. It was half tide and the incoming water helped us along. The nearer mangrove trees had drowned trunks. A fizz and crackle sounded further in, where advancing water ran into crab holes. A smell of salt and ripeness hung in the air. [...]

[Leo] dug his paddle in and turned us into a side creek running up the back of Stewarts' farm. It was spooky up there. High mangroves reached down with crooked arms. The only sound was the splash of paddles. As the creek got narrower I said, 'Jap subs could hide up here.' (pp. 33-34)
}

Guadalcanal thus enters the novel's fictional reality through Jack's and Rex's perceptions, and also seems to underlie the novel's narrative and setting. The amphibians used during Japanese invasions in the Pacific are recalled in Grandpa Crombie's homemade amphibian in which Rex imagines fighting the war. He notes: "I saw myself in the amphib, speeding at a beach with machine gun rattling, then roaring up the sand with no loss of speed, and Japs in the trees falling over and lying dead" (pp. 65-66). The sinking of the Repulse and the Prince of $W$ ales is recalled in chapter sixteen when the Rose and the amphibian sink. And Guadalcanal's battles are evoked in the novel's final chapter when Jack and the children take to the swamplands and fight the military police.

Guadalcanal therefore has a vivid existence as part of the novel's fictional reality and as a force that has shaped characters' personalities and perceptions. Thus individuals and the Kettle Creek landscape reflect larger social and political divisions. Indeed, Gee's historical references do more than account for Rex's world - they symbolise the smaller-scale conflicts of race between and within individuals.

\section{Rex's War}

Rex's racial prejudices merge with his heroic ideals and consciousness of war, not only in Guadalcanal but also in the wider world. In chapter one he blasts images of Tojo and Hitler with his BB gun, and sees himself winning the war single-handed: "I feared [Tojo and Hitler] but I had the upper hand. Sniper in a tree, behind a wall, I won the war with a single shot, time after time” (p. 9). Scorning Tojo's retreat from Guadalcanal, Rex sides firmly with the British in "the real war, where our men were, the one against Hitler" (p. 9). 
Rex's view of life in Kettle Creek as militaristic encourages the reader also to see it in those terms (although not, as we shall see, in Rex's way). His effort to play soldier involves the exercise of control, apparent in his obsession with order, straight lines, and mental and physical narrowness. Together these features are formed into a metaphor for war by Rex who likes things "four square" and who is described by his mother as "an elbows-in-at-the-sides sort of boy" (p. 13). In the chaotic Pascoe household, the young Rex feels that in the very way he eats breakfast, it is up to him to win the war:

\begin{abstract}
I was the only one who sat at the table every morning, the only one who put his spoon straight. I made a little island of order in the middle of it all, but I wasn't obsessive about it. It was just that a war was on and I was the only one who seemed to know. A war meant pulling yourself together, trying to win. All I could manage in that way, in our family, was having breakfast properly, things like that. (p. 16)
\end{abstract}

But paradoxically, Rex's war zone is separate from the real conflicts he is in whilst the "little island of order" (p. 16) that he makes is a place of diminishment and withdrawal, emblematic of his mental narrowness. Rex's bedroom with its war tools, and yet its obsessive cleanliness and order, is thus not only a "battleground" but also a retreat:

I went to my bedroom and cleared the bed. I kept my room tidy and clean. Things weren't thrown about. My American cigarette packet collection on the spare bed was neatly laid out on a tray. My BB gun was parallel to the headboard. The sideboard top was equally tidy. For example, my collection of cartridge cases was arranged according to size. The pictures of fighter planes pinned on the wall were evenly spaced. Mum's broom mightn't go under the beds but when she'd finished I borrowed it and did the job myself. (pp. 16-17)

It is often fear of darkness and death that causes Rex's diminishment and cowardly retreat. In chapter two when the school flag gets stuck Leo, not Rex, contributes to what Rex sees as the patriotic cause: "I got dizzy ten feet from the ground. When [Leo] held on with one hand and worked the pulley I had thought I was going to black out” (p. 23). With Jack's presence at school in chapter five, Rex imagines withdrawing into the trenches: "I went to school knowing Jack would come to our class. I thought of hiding in the slit trenches after lunch but I was a law-abiding boy and didn't have the nerve" (p. 45). And when Jack looks to Rex for help, Rex shrinks: "I saw Jack's eye on me. He was asking me for help, but I had no thought for anyone but myself. All I could do was sink again, hide in my seat" (pp. 50-51).

Rex sees Jack's presence in terms of war as an invasion, particularly of his bedroom and school. Projecting onto Jack his own cowardice, he views Jack's fear as cowardly. In chapter four when Jack mistakes Alf's whistle for a shell he appears diminished and defensive: "He dropped his cigarette and curled himself down in the bed, half on his side. His hands went up and covered his head" (pp. 44-45). Similarly when Marv shoots at Jack 
at the gala, Jack seems to decrease: "His chest hollowed and his arms hooked round. His head dived for cover in his shoulders. [...] He straightened up. But somehow he was smaller than before" (pp. 92-93).

However, whilst making Kettle Creek's racial conflicts an analogy for war, Gee provides images of balance. The symmetrically grouped three children and Jack could be thought of as representing the allies. Set against them are the four police who can be further divided - Davies and Forbes are civilian police, and Riley and Bartz are military police. Thus the historical context impinges on the action, and is also mirrored by it whilst the establishment of Kettle Creek as a war zone allows Gee to redefine heroism, suggest psychological states, and explore division and wholeness.

\section{Race Wars in America}

Aside from emphasising the close relationship between war and racial tension in Kettle Creek, Gee alludes to racial discrimination existing in America when Jack's father would have been alive. During World War II racial discrimination was rife in the United States with countless outbursts of violence, particularly between white Americans and what were regarded as "inferior ethnic minorities - African Americans, Asian Americans, Native Americans, and Hispanic Americans". ${ }^{20}$ Whilst the war benefited the blacks in that it created employment, segregation continued even in the armed forces. Blacks were still regarded as an underclass and, living in slums, were deprived of educational opportunities, and reduced to menial forms of occupation. Articulate Blacks pointed out that the evils of the Nazism that America fought were replicated in the racist South. In 1943 there were approximately 250 race riots in northern cities.

Between 1910 and 1940 the problems were exacerbated by the shift north of thousands of southern Blacks looking for employment. By 1940, in some major cities such as Chicago, the Black population had grown by as much as 250 percent. Employment apparently consisted largely of heavy industrial work in, for example, stockyards and auto factories, whilst Blacks mostly lived in substandard urban slums or “ghettos". For some Whites, Blacks simply didn't exist. In San Francisco Blacks were forced to beg, or effectively efface themselves to avoid persecution, whilst privileged Whites withdrew to mansions on Nob Hill. The racial violence culminated in what became known as "the Red Summer of 1919" when a black bather crossed the colour bar - an unmarked line segregating Blacks from Whites on a Chicago beach - and triggered off the worst race riot in America's history. ${ }^{21}$ 
Allusions to the American Civil War (April 1861 to May 1865), during which a supposedly united nation was divided, increase the novel's resonance and emphasis on division involving race and war. At the time of Abraham Lincoln's election to the presidency in November 1860, there were approximately four million slaves working in the south. ${ }^{22}$ In September 1862 his Emancipation Proclamation effectively released Blacks from slavery and allowed them to enlist in the armed forces. But Lincoln knew slavery to be a divisive issue and in his second inaugural speech in March 1865 identified it as the cause of the Civil War four years earlier: "One eighth of the whole population was coloured slaves, not distributed generally over the Union, but localised in the southern part of it. These slaves constituted a peculiar and powerful interest. All knew that this interest was somehow the cause of the war". ${ }^{23}$

Of course, the Civil War pitted the industrial northern states (the federals or "Yankees" who supported the union) against the cotton producing southern states (the despotic confederates who, wanting to maintain slavery as the basis of white prosperity, favoured self-determination). The war was centred in the south, particularly in Tennessee, Georgia, and Virginia whose invasion by the federal army was assisted by the United States Cavalry. Confederate forces (under generals such as Stonewall Jackson) had an average age of twenty-six (and thousands of much younger men - or "boys" served on both sides). In November 1863 the crucial Battle of Chattanooga opened up the Confederate heartland to the Union forces. The Unionists made further advances into the interior with the Battle of Atlanta in Georgia in September 1864. Following victory, Union general, William T. Sherman and his sixty two thousand men marched on through Georgia inflicting damage until, in December, they reached Savannah and the sea.

With General Robert E. Lee's surrender at Appomattox, Virginia, on 9 April 1865 the war was effectively ended. From 1865 to 1870 three amendments to the Constitution were passed: slavery was abolished, racial equality was recognised, and Blacks gained the right to vote. But the ensuing reconstruction constituted a dark age. Carpetbaggers and "scalawags" exploited the south and persecution of the Blacks continued. Even into the 1960s "Black codes" and Jim Crow Laws systematically segregated and discriminated against African Americans. The Ku Klux Klan (a purist sect of Confederate veterans) originated in the Ozarks during this dark age and a reign of terrorist violence ensued with thousands of Blacks killed. ${ }^{24}$ 


\section{The Novel}

In chapter four Rex remembers his father's friend describing "negroes in the forces [as] 'the scourings of the slums"' (p. 38). But it is largely through Jack that Chicago's discrimination against impoverished Blacks in the 1940s is revealed. On his first night at the Pascoes' home he describes these conditions: "[The bedroom] ain't small to me, ma'am. Where I grew up on the South Side we all slept in one room. [...] Eight kids in three beds" (p. 43). In chapter nine Jack acknowledges living in slums: "I don't have no house. My mammy, she's got two rooms. In a tenement house [ . . ] with big rats instead of puppy dogs. [...] Yeah, slum" (p. 83).

Jack also recalls America's diverse ethnicities in the 1940s. In chapter five he describes a Chicago inhabited by "Irish and Italians and Polacks and Swedes and Germans" (p. 51). He is aware of Blacks' employment in industries such as stockyards and auto factories, noting that "black people" work at "lotsa things. They work on the railroads and in the stockyards. In the meat works, you know, the cannery. Lotsa things" (p. 51). In chapter nine Jack recalls such work when he tells Leo: “ I don't have no job. I learn about cars though. I wash cars and look in the motors. Learn that way. Washin' cars, that's better than the stockyards" (p. 83). Recalling the self-effacement streetwise Blacks used to avoid persecution in San Francisco, Jack smuggles sugar: "Jack moved fast out of the shop without the grocer seeing. He'd grown up on the streets of Chicago. He could cross a public road invisibly and slide down an alley like a cat" (p. 76).

At school Leo questions the cruelty to blacks typifying early twentieth- century America: "Do Negroes still get flogged with whips?” (p. 52). Certainly Jack's father must have experienced persecution during the race riots of 1919. As Jack tells Rex in chapter nine, "Men like [Marv] killed my daddy. [...] A mob of them, they chase him in an alley. [ . .. ] They killin' lots of niggers 'bout that time" (p. 86). By emphasising characters' racial prejudices, and the projection of these onto Jack and others, Gee extends the novel's very credible realistic dimension and Kettle Creek as a version of White American extremism.

In Rex, racial prejudices merge with his obsession with heroism and war. In chapter one he throws clods of earth at Tojo as a "yellow dog" (p. 9). And in chapter four he kicks Jack's bag because Jack is black: "I gave the bag a short hard kick before picking it up. 'Nigger bag"' (p. 39). Miss Betts is similarly racist and attacks Leo, more because he is Dalmatian than because of his rude drawing. As Rex notes, "She wasn't going to miss the chance of beating Leo" (p. 48). Thus American extremists' beating of blacks may be recalled when Miss Betts straps Leo. 
A sort of "everyman" Jack seems to stand for all racial minorities. An embodiment of "good" and the direct antithesis to Rex, he is also a projection of characters' repressed dark sides in that he is perceived as dangerous, dirty, or inferior. For example, after shaking hands with Jack, Rex wipes his hand: "I stepped back and wiped my hand on my trouser leg. It wasn't deliberate. I just found my hand wiping there" (pp. 37-38). For Marv and Herb the colour bar still exists. Playing pool and dropping the ball, Marv speaks to Jack as a slave, calling him "nigra" (meaning black), and commanding him to "pick that up, boy" (p. 85). At the boxing match Marv's metaphor for dishonesty reveals his belief Jack is dirt: "Can't fight clean with nigras" (p. 105). Yet it is Marv and Herb who more closely resemble Jack's "unclean" side and who fight "dirty" and are morally corrupt.

The irony of such projections is that the national and racial identities of the characters who confer them are ambiguous. Rex is a New Zealander yet identifies with Great Britain; Leo has Dalmatian or Croatian ancestry; Dawn has Pakeha and Maori ancestry; and Jack, of course, is an African American. No-one can therefore claim to be racially "pure". National and racial ambiguity drives characters" thoughts and behaviour, and stands for inner division. In projecting their suppressed fears onto each other, characters are also influenced by others' projections. As we shall see, the interweaving of these perceptions and the fact that, although racially divided, the children and Jack form a symmetry of four, are part of Gee's pursuit of an integrated whole.

In looking back to the American Civil War Gee as author parallels the adult Rex who, recalling his childhood and historic past and, engaging in "time travel, [goes] backwards in time” (p. 7). Allusions to the Civil War bring into Kettle Creek a deeper sense of a divided historic past. For instance, Lincoln's Emancipation Proclamation of 1862 is recalled when Miss Betts remarks in chapter five, “The darkies of America are equal. They're treated very well since Abraham Lincoln" (p. 53). Historic racial conflicts seem to fuse with personal conflicts. Thus Leo's question, "Do Negroes still get flogged with whips?" (p. 52), may apply to the whipping of Blacks in the historic past and to his own systematic beatings by Miss Betts. Marv and Herb exemplify the worst of both sides in the Civil War. The Northerners are recalled when they are described by Kettle Creek residents as "our Yankee friends" (p. 75) and as "the US Cavalry" (p. 94) whilst the Southerners are recalled when they are named "the Ozark boys" (p. 20) and "Southern boys" (p. 30).

The battles of the Civil War seem to be paralleled by the conflicts and competitions at the gala. In chapter ten war becomes explicit in the tug of war, the greasy pole (a game in which opponents bash each other with sacks of straw), shooting range, mallet game, and amphibian rides. The conflict of Northerners and Southerners is echoed when Jack 
(from Chicago) is shot by Marv (from the Ozarks), as observed by Rex: "When they came close to the waiting crowd [Marv] saw Jack. [As the amphibian] went past us Marv reached down and grabbed my BB gun. He stood up, straddle-legged, and aimed at Jack" (p. 92). And Chattanooga, battle site in 1863, might be remembered when Jack plays the song, "Chattanooga Choo-choo" on his mouth organ. As Rex notes at the gala day: "It was the outside world coming to town. It was the USA in Kettle Creek" (p. 98).

However, parallels between the military and racial themes of the Civil War and Kettle Creek are ironic, for Gee reverses and thus balances events occurring over time. During the Civil War "Yanks" referred to Northerners, but in Kettle Creek in 1943 the term refers to all Americans. Similarly, the "US Cavalry" referred to the federal army's mounted forces, whilst in Kettle Creek it defines any aggressive American. Where in the Civil War "Southerners" were privileged slave owners in the Southern States, in Kettle Creek the term refers to any American who is domineering. Where battles of the Civil War were bloody and brutal, "battles" in Kettle Creek take the form of competitive sports in which little or no blood is shed. And Chattanooga, a battle site in 1863, is the title of a popular song in 1943. Altogether then, Gee depicts Kettle Creek's relatively mild surface whilst suggesting beneath it lie the historic divisions that resulted in bloodshed and war, and that shaped characters' attitudes.

\section{The American Revolution}

Gee's narrator continues to "go backwards in time" (p. 7) by alluding to the American Revolution (1775 to 1783). Predominantly a war between Great Britain and America, the Revolution was, of course, the outcome of the alienation of the imperialist motherland from her colonies who resented her imposition of autocratic tax laws aimed at protecting her trading rights and profits. ${ }^{25}$ However, the war was not just about independence. It was also a civil and racial war, with those faithful to the parent country ("Loyalists" or "Tories") pitted against the rebels ("Revolutionaries" or "Patriots"). African American slaves were promised freedom by the British, and joined the Tory forces, but were never actually given freedom.

With the Franco-American alliance of February 1778, the British abandoned hope of victory in the north and attempted to penetrate southern colonies. But they had over-looked Georgia's anti-British tradition and its minimal degree of loyalist support. On 14 February 1779 in Kettle Creek (a small town in Georgia's backwoods) a key battle took place. It was described as "the only major Patriot victory in Georgia during the Revolutionary War". ${ }^{26}$ For Kettle Creek's surrounding swamplands posed 
difficulties for the Loyalists whose army included only six hundred men who eventually surrendered or fled. Finally the British and their southern supporters realised the futility of their hope of restoring the South to the King. ${ }^{27}$ A key figure during the Revolution's later stages was the Whig Colonel James Jackson, whose Georgia Legion of troopers fought infamous loyalist Thomas Brown and his troops on the southern frontier. Following a battle in the Ogeechee swamps outside Savannah, Jackson led the victorious Whigs into Savannah after that town's surrender. ${ }^{28}$

In response to the British army of skilled, professional soldiers, the Americans formed their own force - the Continental Army - under commander-in-chief, George Washington. But Washington found it difficult to boost morale and pay his largely untrained men. In August 1782, he established the Purple Heart award with the aim of providing them with an incentive. The medal was awarded for performance of "any singularly meritorious action". ${ }^{29}$ Only three soldiers ever received it before the war ended with the Treaty of Paris in $1783 .^{30}$ However, the Purple Heart was reinstated in February 1932 to celebrate George Washington's 200 ${ }^{\text {th }}$ birthday, and was awarded to soldiers wounded in the call of duty during World War II.

\section{The Novel}

The American Revolution has a real presence in The Champion. A British colony (as Georgia was during the Revolution), New Zealand as depicted by Gee retains the imperialist motherland's traditions, including its militaristic systems of education and governance. British expansionism is promoted by Miss Betts in chapter five when, pulling down the world map, she displays the Empire in dominating red: "She reached behind her, pulled a cord, unrolled the world like a blind [ . . ] in which the red of Empire stood out bold” (p. 51). Rex - loyal to the Empire - drills his platoon at school and at the gala the band marches to "Colonel Bogey" (p. 95). Furthermore, Davies, Forbes, Riley, and Bartz, the civilian and military police, enforce British law and order.

But Kettle Creek also has its revolutionaries who flout the law and effectively rebel against Great Britain. Alf Pascoe and George Perry engage in illicit drinking, smuggling sugar, and betting whilst eventually Leo, Dawn, and even Rex break the law to save Jack from the military police. The fictional Kettle Creek during World War II is as racially divided as America during the Revolution. Mrs Stewart has rejected Jimmy as son-in-law because of his race; others in spite of race enforce British law, like Bob Davies, the Maori policeman; and Jack has been conscripted to the army to fight for the British. 
Most significantly, the fictional Kettle Creek, presumably named to evoke what Rex describes as "a tin-pot town" (p. 37), also evokes the real Kettle Creek and, by coincidence or design on Gee's part, resembles it in several ways. Like Kettle Creek in Georgia, Gee's Kettle Creek has swamplands. In February 1779 the real Kettle Creek was at war with imperialist forces. In February 1943 Gee's Kettle Creek is also at war with imperialist forces. Where Colonel Jackson was a Whig who led the Georgia Legion against the Tory forces, Jackson Coop is liberal-minded and leads his "forces" (the three children) against the MPs and an unjust British system of conscription. Where Colonel Jackson fought in Georgia's swamplands and (according to his adversary Thomas Brown) demonstrated cowardice, Jack conducts his battles in Kettle Creek's swamplands and is seen by the MPs and Rex as a coward. And where soldiers were awarded the Purple Heart during the Revolution, Jack has been awarded the Purple Heart during World War II.

Parallels between the real and fictional Kettle Creeks emphasise ironic differences. In Georgia's Kettle Creek rebel patriots fought against the British cause, but in the fictional Kettle Creek patriots fight for the British cause. During the Revolution the Purple Heart was awarded for bravery demonstrated during war against the British. During World War II the Purple Heart is awarded in recognition of a wound gained fighting as a British ally. In 1783 America won its independence from Great Britain, but in 1943 New Zealand is still strongly affiliated to Great Britain.

By creating correspondences and contrasts between past wars and World War II in Kettle Creek New Zealand, Gee seemingly seeks to balance the past and suggest the instability of values (such as loyalty to Empire) and definitions of heroism over time. His fusion of real and fictional wars makes the novel weighty, textured, and whole. The changing context gives a single moment its meaning, and the moment takes its fuller meaning from the history that has shaped it. Kettle Creek becomes a microcosm of all worlds that have experienced war.

\section{Portraiture}

Gee balances the novel's vast historical canvas with an equally vast imaginative canvas that includes expressive forms such as portraiture, hero worship, performance, authorship, and dream. Through these, characters reveal inner divisions that echo historical conflicts.

Leo's and Rex's portraits are set against each other and depict degrees of harmony and division. Leo's drawings are evidence of his maturity and fuller view in that they accommodate movement and mortality. Three-dimensional, realistic and insightful, they express thoughts and emotions, as the adult Rex acknowledges: "Leo [ . . ] had a gift. 
He drew landscapes full of people doing things. He drew men digging holes and women sweeping floors. He drew faces that were smiling or frowning, you could see what was going on in people's minds" (p. 47). In chapter five Leo's portrait of Grandma Crombie releases her from himself. As the movement away from the book suggests, it has its own life: "It looped away from the book and settled on the floor by my desk" (pp. 47-48).

On the other hand, Rex's portraiture constrains, and is one-dimensional and static. A projection of his mental and physical narrowness, it reveals his puritanical self whilst suggesting a suppressed dark side. In chapter one Rex caricatures "the enemy" "Tojo was the Japanese war leader. I drew him with slanty eyes, forty-five degrees, and buck teeth coming to his chin. Hitler had a blacked-in forelock hiding his left eye and a moustache like a Maori bug” (p. 8). In chapter two, anticipating a Yankee hero's arrival Rex, imitating cartoon comics, draws a cartoon outline that captures only emptiness and death. Ironically, the "Yankee soldier bayonetting a Tojo-faced Jap through the middle" and the speech balloon saying "Die yellow dog!" (p. 26) is a recreation in his own image, for it exactly echoes his actions and words in the previous chapter: "We played games of that sort in the war years, stalking Germans in the grass, bayonetting Japs [...]. 'Die, yellow dog!"” (p. 9). The adult narrator's later comment - "I couldn't draw to save myself, my people and cars and aeroplanes had to be in profile" (p. 47) - suggests the young Rex's failure to see a whole rounded truth, or control his savage nature. In a further portrait depicting Jack as boxing champion, Rex reverses his white killing black motif to show a black knocking out a white. But in glorifying violence Rex, like his drawing, remains primitive and one-sided: "[The drawing] was my usual crude affair, drawn side-on. A man, coal black, in boxing shorts and gloves, knocked a white boxer backwards through the air with an uppercut" (p. 111).

\section{Hero Worship}

Through hero worship Gee suggests the whole, mixed human being and Rex's imagined transcendence of race, darkness, and mortality. Rex seeks an invincible champion whom he can look up to and worship. He has progressed through a range of real and fictitious heroes, from Daniel Boone, to Tarzan, to Rockfist Rogan (to name but a few). Brave and adventurous, they have tamed wildernesses, transcended reality and time, and achieved legendary status in movies and popular fiction such as comic books. They are also integral to the novel's historical dimension, for Daniel Boone was a frontiersman of the American Revolution and Tarzan conquered the African jungle. Similarly, Rockfist 
Rogan, chief pilot and boxing ace in The Champion (a weekly comic and annual) mastered the air along with Africans and "Huns". Rex emulates his heroes by keeping his bedroom - a version of wilderness and war zone - tidy, ordered, and clean. To Rex the champions represent what is pure, white, controlling, victorious over nature, and eternal.

The young Rex denies mortality by role-playing his heroes and keeping up-todate. He is annoyed when Alf calls him Daniel Boone, and other old-fashioned names, as he notes in chapter one: "My BB gun made [Dad] choose Daniel Boone. If I'd been on my bike he'd have called me Destry or Tom Mix and if I'd been in a tree it would have been Tarzan. These out-of-date heroes made me cross" (p. 10). It is action and life in an eternal present that Rex most wants. Rockfist as a pilot (as opposed to Boone a backwoodsman, hunter and trapper, or Tarzan, an inhabitant of the jungle and climber of trees) is attractive to Rex who, although in close proximity to Kettle Creek's mud, literally likes to look up. He prefers the elevated to the lowly and regards Leo as heroic for scaling the school flagpole and releasing the flag: "Leo was still printed on my mind against the sky, on the moving clouds, on the skinny pole, making me feel weak and tummy-sick and worshipful” (p. 23). Ironically, though, Rex also fears elevation as it may lead to a fall, darkness and, implicitly, death: "I got dizzy ten feet from the ground. When [Leo] held on with one hand and worked the pulley I had thought I was going to black out" (p. 23).

A comic book character, Rockfist (as he appears in The Champion comic book annual) is one-dimensional and hollow - a mere outline on the page. ${ }^{31}$ Indeed, his very lack of complexity and substance gives Rex the space in which to imagine himself. As Scott McLeod has pointed out, the abstraction, simplicity, and universality of the comic book character allow the self-centred human being to assign to it identities and emotions and indeed him/herself. ${ }^{32}$ Acting as a vacuum, Rockfist's outline effectively draws the self-centred Rex into it so that he occupies Rockfist's role and imaginatively plays out Rockfist's adventures. Thus, the comic book's African landscape - the setting of Rockfist's forays, a place of jungles, swamps, creepers, cliffs, crocodiles, and ostriches - seems to influence Rex's perception of Kettle Creek's landscape as a place of romance and adventure: ${ }^{33}$ "We glided over the water with shallow paddle strokes [...] heading along the edge of the cliffs and past the fringes of the mangrove jungle . [...] It would have been easy to imagine crocodiles basking in the mud and snakes sliding in the crooked trunks (p. 33). Rex sees Grandma Crombie's garden in similar terms as an extension of his fantasies: "I might see tendrils reaching and marrows like pythons 
curled in the shade, and feel that I was threatened, food for them. Or I might imagine myself in Africa and put my foot on a pumpkin, a beast I'd shot" (pp. 61-62).

Of course, Rockfist is a projection of the period's Imperialist values and his attitudes, which would be seen today as racist, are upheld as good. Thus in The Champion annual Blacks are depicted as evil or sub-human. An African adventure story refers to them as "coloured boys", "pop-eyed", "dim forms [...] amongst the trees", "a horde of black figures" and "the black tide [that ebbs] back into the cover of the jungle". Rockfist himself is prejudiced and brutal. About to open fire on the blacks, he yells: "Hold your fire till you can see the whites of their eyes", thus referring to them in terms of the standard cliché of the genre. ${ }^{34}$

In appropriating Rockfist's character, Rex expresses this brutal side but sees it as good. The identification with Rockfist actually encourages Rex to behave as a savage. In chapter one he imaginatively kills and dismembers Tojo and Hitler: "I shot Hitler and Tojo from a distance of twenty feet until only tatters of them were left" (p. 9). Ironically recreating himself in the face of the enemy, Rex expresses the savagery of Hitler and Tojo that he believes he is fighting against.

The anticipated arrival of an American GI, whom Rex identifies with Rockfist, allows him to imagine salvation, veneration and love. Instead he is faced with Jack who perhaps recalls the Africans that Rockfist has fought against, and upon whom Rex also projects his own murderous instincts. Acting as Rockfist, Rex again shoots and completely annihilates Hitler and Tojo: "Round on the back lawn, in the dusk, I aimed and shot, aimed and shot, at the Hitler/Tojo box, until I lost sight of the faces in the dark. I lost half a dozen BBs that night but didn't care. I knelt only five feet away and blasted holes in the enemy" (p. 42).

Indeed, Rex effectively uses The Champion and Rockfist to obliterate or annihilate Jack: "I went to bed and read my Champion - Rockfist knocking out Huns with uppercuts and Bill Ross blowing up ammunition dumps. I got right away from Jackson Coop. Jackson Coop didn't exist" (p. 42). As previously noted, Rex views Jack as a savage: "His skin glistened in the light from the moon. I watched him through halfclosed eyes, thinking how easily he could kill me" (p. 44). But the view is a projection of Rex's imaginative destruction of Tojo, Hitler, and Jack. Like the straight-lined bedroom and cartoon portraits, the comic outline of Rockfist Rogan not only feeds into Rex's primitive instincts, but also provides a persona or barrier that defends him against it. 


\section{Performance}

Gee integrates musical allusions with themes related to revolution and war. Through contrasting forms of music and dance, characters imprison or release others. Rex (leader of his school's platoon) enjoys marching to patriotic music. "God save the King" and "Colonel Bogey" have ordered, heavy or regular rhythms suggesting pomp, loyalty, duty, and control. In chapter five Jack uses music and dance to capture and control Miss Betts. His tap dance with its "simple rhythm" (p. 53) recalls the "rat-tattat" (p. 9) sound of a machine gun, earlier mimicked by Rex. In contrast to his usual physical diminishment, Jack expands and surrounds Miss Betts who is diminished. As Rex realises, Jack adopts the persona of Al Jolson (who performed song and dance numbers that parodied African Americans). In mirroring such a racist view back to Miss Betts, Jack confronts Miss Betts with her own racism:

Jack gave a watermelon grin. 'Ye-es ma'am.' Oh that 'yes', I hear it still, mellow, rich, submissive, marvellously false. 'We's happy folks, us darkies.' He let his body fall with a rag-doll flop and the joints all wonky and let his head roll. He shuffled his feet and started to dance. He turned himself into a golliwog. Jack could tap-dance a little. He could tap out a simple rhythm. He went around Miss Betts in that way, floppy arms and legs but fast feet, and that sugar smile on his face. She could not move fast enough but was half a boy-turn behind. She could not catch up and bring him in control. No one had ever got the better of Miss Betts, but Jack had her beaten. [ . . . ] Jack did Jolson's act. (pp.53-54)

Jack's triumph over Miss Betts, and increasing popularity with Leo and Dawn causes him to change in Rex's eyes. Instead of disowning Jack, Rex wants to possess him. As Rex notes in chapter seven: "I was beginning to be possessive. Everyone else seemed to be grabbing Jack and although I mightn't like him he still belonged to me" (p. 70).

With the infiltration of Jack's culture into Kettle Creek, Rex becomes more enamoured. Developed by black Americans from their tribal origins in Africa, jazz with its irregular, syncopated rhythms possesses Rex differently to the way Jack's Al Jolson act possesses Miss Betts. In chapter ten, jazz and jive (a freer style of music and movement than marching) break down Rex's barriers, for, effectively wooing the gala's crowd with his mouth organ, Jack also wins Rex's heart. Indeed, the organ, taken from Jack's pea jacket, and played softly and soothingly, then with a "throaty, wild, vibrant, wailing" seems not only "sweet" (p. 97) but also sexual, organic - even pre-linguistic. As Jack bends forward and leans back the music becomes a sort of primal lovemaking:

Jack's music was soothing - and later on, throaty, wild, vibrant, wailing, sweet. It made me catch my breath. It made my heart swell until I thought it would leap out through my mouth on to the grass. [ . . ] Jack stood up and played with his body swaying. Sometimes he bent forwards and sometimes he leaned back, and his hands, cupped over the instrument, imprisoned and let free wonderful sounds. (pp. 97-98) 
Rex succumbs to Jack's "lovemaking” and moves beyond his usual boundaries of control. Noting "I had no rhythm in me"(p. 98), he reveals his lack of attunement to nature and his heartbeat, but at this point becomes aware of his breath, his heart and, implicitly, his mortality. Enraptured, he acquires a hero and falls in love whilst his heart expands to lose itself to Jack. Rex sees the moment in terms of lines - not the tidy straight ones of his bedroom and marching, but curved and expansive. And centrally situated, in control of the crowd, is Jack. Like a cowboy hero with rope lasso, Jack seems to loop his music out over the crowd, and capture and conquer Kettle Creek and Rex. But ironically, where Jack may be expressing what is wild, dark, and instinctual, Rex projects onto him the heroic and civilised, and the world of light:

The music went out and over the crowd, it looped out like a rope and caught them in. If you'd been high in a tree you would have seen them flowing in to a point, and Jack there like the hub of a wheel.

[... . He slipped his mouth organ into his pocket and grinned at Mum and held out his hand. In her gypsy dress, head scarf in her hand, she went flying in, and they danced to the clarinet and drum and accordion. The other dancers fell back to the edge of the circle and Jack and my mother put on a show. [ . . ] It was the first real jiving that we'd seen, outside the pictures. It was the outside world coming to town. It was the USA in Kettle Creek. (p. 98)

Echoing Jack's expansiveness and possession of Rex and the crowd, Rex with swollen heart sees Jack in terms of his heroes: "I stood by Jack, beaming with pride. He was mine, and every bit as good as Buddy Storm” (p. 98). When Jack spears Marv to rescue Gloria, Rex elevates him to the role of Rockfist. However, the view of Jack as hero is as much a projection of Rex as the earlier view of Jack as killer. Moreover, Jack's role as comic book hero allows Rex to share the limelight, and capture and possess him. In this battle of hearts, then, Rex is victor: "Before the crowd came swirling across, with chatter and grin, I was alone, and I realised my victory. I had my Jack. I had my Buddy Storm, my Rockfist Rogan” (p. 100).

With Jack's performance at the boxing match his ascent in Rex's mind is complete. Surrounded by the boxing ring, Jack is also metaphorically encircled by Rex: "I would probably have said, 'Jack's mine,' but Leo tugged me away” (p. 104). Rockfist Rogan ("Skyways KO King", boxing ace, and tigerish fighter) is recalled when Alf introduces Jack as "Tiger Coop" and he knocks out Marv. ${ }^{35}$ From his vantage point in the tree Rex explicitly identifies Jack with his hero, yelling: “Come on Jack! Come on Rockfist!” (p. 106). Imaginatively possessing Jack, Rex is also possessed by Jack. Tree-borne, Rex forgets his fear of heights and looks down on his hero. The position anticipates the 
narrowing of the distance between the primitive, innocent child and the urbane, experienced man, and Rex's greater insight when Jack eventually falls from grace.

\section{Authorship and Language}

Authorship further reveals Gee's concern with wholeness as he sets different sorts of authorship against each other. Some, through writing, seek the pure and eternal; others seek mortality and life. Some written forms imprison and control; others demonstrate freedom or release.

These dichotomies are apparent in Gee's setting of a poem seeking the eternal against a poem acknowledging life. Miss Betts' pretentious poem, written for the gala, attempts to transcend life. But it actually excludes movement and life every bit as much as Rex's portraits, whilst its rigid order recalls the militant "Colonel Bogey" march. Thus within its smug tone, regular iambic rhythm, and rhyme, Kettle Creek is as trapped and diminished as Miss Betts unwittingly declares it to be within the hills of New Zealand:

So, folded in the hills' embrace,

Caressed by warm and swelling sea,

Our town dreams in its one true place,

And this we hope will ever be. (p. 97)

Conversely, Bernice's poem acknowledges freedom, and its movement and liveliness resemble Leo's portraiture, whilst its irregular quirky rhythm recalls Jack's syncopated jazz and jiving. The anapestic rhythm and hyphen therefore contribute to the humour and movement of this "funny little town" which, in contrast to Miss Betts's static town, is linked to the outside world, its troubles, and Kettle Creek's mud and hills. Thus Bernice's poem admits mortality and death, but actually has much to do with lightness and life:

Funny little town with your feet in the mud and your head lifted up to the hills -

And one dusty road to the world outside

And all the wide world's ills. (pp. 13-15)

A fictional author's use of language therefore suggests his/her degree of balance. The language of Rex, as the primary author who writes the novel we are reading, is particularly revealing of Rex, and also Gee. For, as previously noted, the older Rex and Gee are parallels - both look back on childhood to write the book we are reading. The older Rex's effort to "speak with his Standard Six voice not [his] grown-up voice" and "to say how it was and not change the shape of it by putting in ideas [he has] thought of since” (p. 7) suggests he wants to capture a linguistic and historical truth. Thus he (and 
Gee) reflect on the way words work, and also allow characters to speak in their own dialectally and grammatically varied voices.

For example, Gee sets Miss Betts and her "proper" English against characters who speak European and American dialects. On the one hand, Miss Betts, a grammarian, upholds what she considers to be the "purity" of standard English just as she upholds the traditional values and educational system of old England. On the other hand, Stipan and Leo use what in this context could be thought of as an impure or corrupted version of English and so, of course, does Jack.

The formal conventions and complete sentences of Miss Betts' traditional English correspond to her search for perfection, closure and mental elevation of herself above others. Interestingly, in the example below, the narrator's ungrammatical use of "noone but her" (instead of "no-one but she"), if intentional, suggests his empathy with Leo, and preference for fluid, colloquial language over fixed grammatical rules:

[Miss Betts] thought no one but her knew the English language, and she went round
with her ruler in her hand pointing out wrong grammar and punctuation and chopping
you on the knuckles for a really bad mistake. Starting a sentence with 'and' was a bad
mistake, or ending one with a preposition. Slang was the worst mistake of all.

Chop went her ruler on Leo's hand.

"'Loony' is not a word. Nor is "gosh."”

'People say “gosh”, Miss Betts.'

'Not in my class. What's this? "Having a rotten day." How can a day be rotten, boy? A day can't go bad. A day can't smell.' (p. 47)

Miss Betts further reveals her snobbishness by saying: "Listen to how [Jack] drops his g's" (p. 50). Indeed, Jack's compressed words and sentences indicate racial inferiority, according to Miss Betts. Moreover, his physical shrinking is echoed by a linguistic shrinking in the contraction of "let me" into "lemme" (p. 65), "come on" into “c'mon" (p. 125), and "are not" into “ain't" (p. 170). But of course Jack's dialect results from the merging of nations and subordination of race. It is, therefore, immensely ironic when contracted language indeed anticipates physical diminishment and even death, as it does in chapter thirteen. Here the reversal, abbreviation, and faded outline of Jack's title on his bag suggest Jack's reversed fate, and future jeopardy: "There was Jack's name - Coop, J. E., Pte - stencilled in faded black on his khaki bag" (p. 124).

Nations and dialects further merge as characters, becoming close, adopt each other's language. Jack refers to a "wrench" to be told that it is a "spanner" (p. 65) by the younger Rex who then adopts Jack's term "wrench", to be corrected by Grandpa who tells him it is a "spanner" (p. 132). Similarly, Jack adopts the colloquialism "too 
right" (p. 86) from Rex, and Rex uses the Americanism "rabbit stoo" (p. 173) acquired from Jack (p. 128). Rex's changing relationship to Jack is thus highlighted in reversing language patterns. Aware of these, the older more thoughtful Rex comments at the beginning of chapter four: "Negro' was the word that we used then. 'Black' was supposed to be insulting. Today it's the other way round" (p. 37). Perhaps he is speaking for Gee who seems to suggest that the changing context gives words their fullest meaning and who integrates language with the fictional reality.

Through authorship and the examination of his recent and a more distant past, the older Rex effectively explores his childhood and collective origins. Structurally, therefore, the novel seems to embody his psyche. His adult self at the novel's beginning and end can be equated to the psyche's more rational surface. His childhood within this frame resembles the infantile mind and its dreams, especially the dream of Jack, whose relationship to the younger Rex effectively defines the older Rex. The novel's representational style - that of the comic book adventure story - suggests the older Rex's recreation of his past favourite genre. This is confirmed in the novel's title - The Champion (after his childhood comic) - and in his replication of comic book features - action, adventure, conflict, goodies and baddies, and phrases such as "meanwhile” (p. 157).

However, the portrait of Jack has far more substance to it than the younger Rex's comic drawings or the character of Rockfist. As we have seen, the interweaving of personal and public histories gives the novel solidity and makes Jack a realistic individual as well as a symbol of good. Also, through becoming reacquainted with Jack, the older Rex learns about dimensions to himself that he must integrate to achieve wholeness. That the older narrator frames Jack within the circularity of his own point of view at the novel's beginning and end, suggests he moves beyond his boyhood's empty outlines and constructs a written portrait that is rounded and substantial. The novel's structure therefore reflects Rex's control and placement of himself on the periphery. Effectively eternalizing Jack within the frame, the portrait nevertheless resists fairy tale and dream. That the adult Rex, an entomologist, balances the fiction of his childhood with the pragmatism of adulthood (having written a book about wetas) suggests his greater realism.

Rex also avoids fairy/adventure tale's happy endings of fairy tales and adventure stories that gives closure, and concludes instead with a note of possibility and doubt. He is not going to project death onto Jack, or invest Jack with the hero's invincibility, as he did when young. Instead, effectively holding past innocence and Jack still within his ordering mind, the mature narrator slips into the present tense and seemingly opens out to allow Jack freedom, movement, and space. In a sense, then, the older Rex gives life 
to Jack as a projection of his own goodness (or soul), and Gee achieves Raymond Sole's ideal integration of movement and tranquility: I study insects at the DSIR. I'm writing a book about wetas. And, of course, I've
written one about Jack. Here it is. I had to write it $[\ldots]$.

I often wonder what happened on the launch at the very end. Jack probably tried to save Mrs Stewart. That is the sort of thing he'd do. And then perhaps he tried to swim ashore [... ]. And sometimes I wonder if he made it - just kept on kicking, paddling, as we'd taught him. Reached the other shore and pulled himself through the mangroves there. Was that someone moving, someone slipping quietly away? And he hid in the bush, up the coast where Dawn had shown him on her map; and somehow managed to survive - rabbit stoo and travelled to Chicago after the war. He's in Chicago now, living happily...

It's a dream. Perhaps I don't need to dream it any more.

I’ve never forgotten Jack, and never will. (p. 173)

\section{From the Mythical to the Elemental}

Thus Gee balances fairy tale and adventure story with reality whilst, like Ellie, he recognises that myth allows a deeper communication. He establishes Kettle Creek as an Eden cut off from the wider world, suspended in time, and yet with divisions. To Rex, the innocent child, it is a playground of eternal bliss in which he acts out dreams and adventures. Here Eden's first man is recalled in the patient Jack, and Eve is echoed in the worshipful Grandma Crombie who offers her garden's fruit to "Adam". But the "garden" also has reptiles, devils, beasts and shadows: the hissing, "shady" George Perry "sidling up or sidling away" (p. 19); Marv with his red-eyed satanic fury; "crocodiles basking in the mud and snakes sliding in the crooked trunks" (p. 33); and Rex who darts "snakily" at Dawn (p. 108).

Gee fuses Old and New Testament motifs. Bernice, maternal yet flirtatious, resembles Mary mother of Christ and Mary Magdalene. Jack's initials (“J. C.”), his gentle nature, and rescue of Alf and Gloria, recall a loving Christ or saviour. A reluctant soldier bearing a scar, he has seemingly suffered for mankind whilst his persecution by Marv, Herb, and the military police, and death echo Christ's persecution and crucifixion. Jack also experiences what could be thought of as three resurrections. These include his rejuvenating stay in Kettle Creek, his return in chapter thirteen to a lost Paradise, and the God-like older narrator's re-creation of his character within the novel.

However, such mythological parallels are ironic. Whilst Kettle Creek may comprise a heaven for some, for others it is the opposite. For example, bombarded with clods thrown by Rex, Alf yells: "What the hell!” (p. 13). When Jack first arrives in Kettle Creek, it seems redolent of death - "the end of the world" (p. 37) - and that this Christ is black causes Rex to believe he is a devil. In fact, Jack is human, not divine or demonic, and his cowardice and foolishness are largely responsible for his misfortune. 
That the three children, like the three magi, give their "Christ" gifts heralds Jack's final death rather than his resurrection.

We are therefore never allowed to forget that, although symbolic, characters are human. Gee also shows them to be closely connected to the primordial from which they originally evolved. Indeed, Kettle Creek becomes a prehistoric landscape and characters also have this elemental dimension. Gee therefore emphasises bodily functions, particularly ingestion. Aside from literally contributing to physiology, food and ingestion are powerful metaphors that reflect characters' underlying emotions. For instance, at school Rex finds Jack hard to accept: "My stomach gave another turn. Jack stepped in. [ . . . ] I hadn't understood how black he was” (p. 49). When Jack goes AWOL Rex finds friendship bitter: "Friendship seemed like something I must swallow. It hurt like the arm across my throat. I did not want friendship if that was it [ ... ]. My throat ached where [Leo's] arm had pressed” (p. 127). But eventually Rex effectively ingests Jack: "I swallowed and sniffed and wiped my arm across my eyes. 'Friends,' I said, and thought it was a stupid ugly word. All the same it could not be got round" (p. 127). Finally, when Jack leaves for good, it is the absence of friendship Rex finds bitter: "This was goodbye. [ ...]. My stomach seemed to shrink to the size of a green apple" (p. 140). Through these metaphors Gee suggests the degree to which both physically and mentally Jack becomes part of Rex.

A similar reciprocity exists between characters and the landscape. Bernice's poem personifying landscape suggests the proximity of human and land, and reality and dream, as Rex notes in chapter two: “As Mum's poem said, Kettle Creek had its feet in the mud and its head in the hills" (p. 18). In chapter three when the younger Rex and Leo venture out in Leo's canoe, the primordial swamplands reflect Rex's harmony with nature, whilst Rex seems one of its beasts. Festering yet fecund, feeding off its own waste and regenerating itself, the swampland has dualities that are mutually engaged in a process of ingestion, reproduction and extinction, and that almost take on reptilian or mortal form. Commenting ironically on Rex's creation of and consumption by his fantasies, this symbiotic landscape as a projection of Rex is experienced by him with fear and delight:

We glided over the water [...] heading along the edge of the cliffs and past the fringes of the mangrove jungle. It was half tide and the incoming water helped us along. The nearer mangrove trees had drowned trunks. A fizz and crackle sounded further in, where advancing water ran into crab holes. A smell of salt and rot and ripeness hung in the air. It would have been easy to imagine crocodiles basking in the mud and snakes sliding in the crooked trunks. (p. 33) 
In chapter four the effect of Jack's arrival on the younger Rex is described in a metaphor that merges the landscape and the human. As the older Rex notes, language (the metaphor itself), landscape and the human are subject to time and, reflecting his (and Gee's) socialist beliefs, a staunch interrelatedness between humans is necessary to counteract suffering and death:

\begin{abstract}
I lay there with the bottom dropped out of my world. That's a tired old metaphor. Let's see if I can find a better one. Down in Fiordland you see huge scars of rock shining in the bush on the mountainsides. The trees can't put down roots. They hold each other in place until one loses its grip and then they all go, acres of them, down into the waters of the fiord. This is called a tree avalanche. I felt as if something of that sort had happened to me. Something I'd thought surely rooted had slid away and a glistening scar was in its place. (p. 43)
\end{abstract}

By contrast, the primitive younger Rex's mixed feelings about mortality - the fear, but also the bliss of losing one's self in nature - are projected onto his grandmother's garden with which he imagines a reciprocity:

\begin{abstract}
Beans over-reaching their frames waved at the top and marrow and cucumber vines crept out the bottom.

[ . . ] Grandma's garden affected me differently each time. I might hear growth humming and roots drinking and sap running and fat leaves creaking as they turned to follow the sun, and might start humming myself and feeling my own sap rising in my limbs. Or I might see tendrils reaching and marrows like pythons curled in the shade, and feel that I was threatened, food for them. Or I might imagine myself in Africa and put my foot on a pumpkin, a beast I'd shot. Or simply be hungry - pick a tomato, crunch a butter bean. (pp. 61-62)
\end{abstract}

Jack also empathises with nature. Metaphors of ingestion suggest his initial discomfort at seeing Kettle Creek: "He'd come to the end of the world, our tin-pot town, our single street with paddocks at the end of it and sea beyond the paddocks and then nothing but the empty sky. He looked out there and then looked at the hills; and swallowed. I saw his Adam's apple bounce. He licked his lips" (p. 37).

However, like Rex, Jack sees Grandma Crombie's garden in Edenic terms as a sensuous "Wonderland” (p. 62). He eats Grandma's (or Eve's) tomatoes and is sprayed with their "squirting seeds". He plunges his arm into Grandma's compost and finds "it's warm as [his] blood". He sees light and life within darkness when Grandma's worms are exposed, "inch-long, pink and shiny; a spaghetti farm”. Holding them in his hand and effectively "swallowing" them, he takes "deep breaths of the sunny compostscented air" (pp. 63-64). In penetrating nature physically and absorbing it into him, Jack is mentally impregnated, fertilised, rejuvenated, and in touch with his own mortality from which, since Guadalcanal, he has been in retreat. Here, antitheses are balanced in harmony. 
Gee's landscape and his characters therefore contribute to and reflect each other. The landscape's colours recall racial divisions: There is mud that is black, tidal water that is brown, cliffs that are yellow, and dust that is white. Its movements recall the expansionism or diminishment of dream and war: In Grandma's garden beans overreach, growth hums, and sap runs, but cucumber vines creep, leaves creak in following the sun, and marrows like pythons curl in the shade. Kettle Creek's dualities recall cultural differences. There are exotic or cultivated features - the gorse, farmlands and vineyards; and the metal road, wooden houses and corrugated iron shops. And there are features that are natural - the mangroves, clay track, and hills; and the mud and tidal water of estuary and swamps. Barriers separate these features - Barrington Road (where Rex lives) divides the town and countryside, and a "bar" distinguishes the sea from the estuary. Like national, cultural and individual barriers, these threaten to dissolve, allowing dualities to merge. The bar at high tide is overtaken by the sea, a bus from the outside world brings culture to the countryside, and the dust it creates rises into the air. Gee's antitheses thus move and mix. As we shall see, with the breakdown of social and mental barriers, this is also what happens to Rex and Jack.

\section{Rex versus Jack}

Perceived alternately by Rex as projections of his evil and good self, Jack has appeared savage when cultured, and a heroic saviour when unassuming. Rex and Jack develop a closer interaction, but harmony is only possible when one dominates and the other submits. With the narrowing of distance between the primitive, innocent child and the urbane, experienced man, each absorbs traits from the other, eventually to resemble the other's original state.

In chapter twelve on their last afternoon together, the children and Jack eat apples in a brief communion. Miss Betts in chapter five has linked apples to the brain. As offered now by Jack (or Adam) to the children, they seemingly symbolise his relinquishment of intellect or "brain," and descent to innocence. As "buddies" (p. 109), all equally childlike in their enjoyment of an Edenic state, the three friends co-operate in teaching Jack to swim. The arrangement - one on each side of Jack and one underneath - comprises a perfect symmetry between the four previously warring characters.

But, of course, in Christian myth eating the apple signals an end to innocence, and in this Eden Rex and Jack will change. Indeed, the idealised moment of happiness contains the potential for a fall. For as Jack descends into the water he also descends in Rex's mind from heroism to a level even with himself. Together with Jack's 
helplessness, this causes Rex to relinquish childish anger and romance and behave in the more rational, mature manner previously characterising Jack. At the same time he recognises Jack's greater wisdom and experience as embodying his better ideals:

\footnotetext{
It was his helplessness in the water that calmed me down and made me start behaving in a reasonable way again. I think we all felt the same towards him - protective, and yet somehow protected by him. Equal to him, accepted, yet innocent and simple and silly alongside Jack and all the things he knew. (p. 110)
}

However, as Rex grows in understanding, he and Jack move apart. In a scene reversing his first night with Jack, Rex acknowledges his mortality and the pain that previously he could not see belonged to Jack. The mental scar Rex experienced on Jack's arrival (described as "a glistening scar" on rock, p. 43) is felt physically on the eve of Jack's departure: "Just as on that first night, [Jack's] face came forward from the dark and sank away. The scar turned pink and faded out in time with it. I felt a dull ache in my own shoulder" (p. 110). Empathising with Jack's suffering, Rex seemingly bears his wound so it is he who now recalls Christ whilst Jack becomes the imperfect child.

Jack's and Rex's final breakfast together resembles a "last supper". The flapjacks, as their name and personification (Jack calls one "he") suggest, are an extension of Jack. In offering them to the Pascoes, Jack offers himself. In consuming the flapjacks and in a sense Jack, Rex physically and mentally expands (as Jack once has) to gain the greater insight that Jack “didn't want to be alone” (p. 113). As Rex comments following Jack's departure, having outgrown Rockfist Rogan, he becomes the mature adult - "too old for that sort of stuff' (p. 120) - whilst Jack "in the water, dog-paddling [ . . . ] worse than a primer kid" (p. 120) becomes as "innocent and simple and silly" (p. 110) as Rex and his friends when swimming.

The brief balance of the children and Jack is further disturbed when Jack goes AWOL. Where earlier Rex was the coward, now it is Jack. Ironically, with his progressive retreat, his skin colour and racial identity seemingly fade. In chapter twelve Rex's sketch depicts Jack as "Tiger Coop" who is "coal black", but Jack refers to himself as the "Brown Bomber" (p. 111), a reference to heroic black American boxer, Joe Louis. In chapter thirteen the stencilled outline of Jack's name on his bag is in "faded black" (p. 124), and Jack's cowardice is perceived by Rex as "yellow" (p. 127). In chapter fourteen when Jack runs for help, the white dust covers his feet. Indeed, the Kettle Creek landscape starts to engulf Jack who seemingly moves beyond innocence to a different sort of oneness with nature than that experienced in Grandma's garden or when swimming: "He was wet and panting and his feet were white with dust from the road" (p. 135). 
Where Jack's movement towards and beyond innocence is accompanied by a lightening of colour, Rex's movement towards maturity is accompanied by a metaphorical darkening. Learning that Jack has gone AWOL, Rex becomes "cunning" (p. 123) and sees the landscape (now a cityscape) as a black hole, recalling Jack's sheltering cave. It also represents the hole that Jack, once real but now absent, leaves in Rex's mind: "It was as if, in a street I passed through daily, something from down below had lifted a manhole cover, and now the hole was there, empty, black; and I waited for whatever might come out" (p. 125).

Like Jack upon arrival at Kettle Creek, Rex must accommodate an inner emptiness. Concerned with "good sense" (p. 129) and taking responsibility, he becomes more thoughtful and intuitive, and exercises the cunning previously demonstrated by Jack. Thus in contrast to his earlier conformity to straight lines, Rex pursues a crooked, shady path. In stealing goods already stolen on "the black market" (p. 132) in order to save Jack, he recalls Jack's stealing of sugar in order to save Alf. Ironically it is now the civilised world and himself that Rex sees as dark, and the natural world and Jack that he sees as increasingly light.

As Jack's colour appears to fade, so too does his humanness. In a counterevolutionary direction he regresses beyond childhood innocence towards a preconscious, pre-existent state. Anticipated by his earlier animalistic appearance (to the prejudiced Rex), and also by his “dog-paddling” (p. 120), this state recalls the previously primitive Rex, and is increasingly associated with water. In chapter thirteen the swamplands appear conspiratorial and greedy in their hunger for food: "The tide made little whispers and sucks in the mangrove trunks" (p. 124). Certainly the landscape reduces Jack's humanness - thigh deep in water, he resembles first "a hippo wallowing" and then "a giant fish" (p. 125). Hiding from Bartz and Riley in chapter fourteen, he descends "waist-deep", then "up to his chin" (p. 134) in water. Becoming clumsier, and knocking over tins and cans in Mrs Stewart's shed, he creates a "bucket symphony" (p. 143) in contrast to his earlier lively jazz. Approaching non-existence, Jack cannot fill emptiness, but contributes to it by pushing his fingers into the launch's "crevasses of rot" (p. 153).

Jack's merging with nature contrasts to Rex's earlier view of him as transcendent hero, and effectively completes the circle of his existence at Kettle Creek as seen by Rex. It forces the now wiser Rex to look down to his "feet in the mud" and see Jack in terms of the primordial nature he projected onto him when first he arrived. But then Jack existed as an embodiment of Rex's evil side, whilst his final clumsy descent confronts Rex with a loss of his soul. 
Whilst Jack becomes dehumanised, Rex through knowing him becomes more humane. His challenge, therefore, is to give up dark prejudice, romance and even love and to accommodate the helpless creature Jack has become. In the final exchange of gifts prior to Jack's departure in chapter sixteen, Rex hands over his Champion. The opening out of the paper, almost of its own accord, is expansive and suggests generosity and Rex's relinquishment of romantic dream: "Jack untied the string and let the paper open out. He smiled with pleasure. He knew how important the Champion was to me" (pp. 149-150). Jack is similarly generous. In pulling the purple medal out of his shirt pocket, he metaphorically gives Rex his heart. Where previously Rex imaginatively encircled and captured Jack, he can now barely close his hand on Jack's heart or acknowledge possession and finality. Effectively Rex receives a medal for his suffering, much as Jack did for being wounded in Guadalcanal. But ironically having battled for, and gained, his hero's heart, Rex in his greatest moment of triumph cannot bear to take it:

\footnotetext{
[Jack] pulled out the Purple Heart [...]. 'You keep this' [...]. He took my hand and put the medal in $[\ldots]$. I could not close my hand on it. It seemed too important, and seemed to mark an ending too much. 'Kettle Creek's the best thing that ever happened to me,' Jack said. So I took it. My fingers closed. I opened my mouth to speak, but could not speak. (p. 150)
}

Rex gives away innocence and childhood; Jack gives away maturity and life. Stranded with Mrs Stewart on the Rose, he contributes to death and emptiness when, wielding a gun, he blasts a hole in the launch's side: "[Jack] reached [Mrs Stewart] in two steps, grabbed the barrel of the gun, forced it down and round, away from Dawn. One barrel went off and blasted a hole the size of a soup plate in the hull" (p. 170). Destroying the boat, Mrs Stewart and himself, Jack recalls Rex who has once imaginatively destroyed Tojo, Hitler, and Jack. Rex on the other hand now uses the amphibian and his BB gun to save rather than to kill: "I saw my BB gun lying in the bilges. I left the tiller, grabbed the gun, held it barrel first at Dawn. She reached it with one hand - and [we pulled] her on board" (p. 172). Rex therefore becomes a different sort of hero to the one he originally imagined.

As the launch sinks, surrounded by dozens of observers, and rescue boats "circle, blindly searching" (p. 172), Jack is again the centre of attention as he was at the gala and boxing match. No longer a hero, he is now a victim who vanishes forever. Jack's "sacrifice" saves Rex's soul and Rex becomes a nicer human being. Almost a saviour, but only a child, he cannot actually save Jack and, in letting him go, must release part of himself. Having created a dependency in Jack that contributes to his fate, Rex acquires with maturity responsibility for Jack's downfall and probable death. 


\section{Conclusion}

Thus the novel's two halves completely reverse. Within this symmetry and the circular frame, Gee captures the patterned exchanges of Rex and Jack, each of whom is an integral part of the other. Where the younger Rex failed to save Jack, the older Rex succeeds by recreating him in the novel. But in looking back and seeking his lost childhood, the older Rex relinquishes self and undergoes a progression towards innocence and pre-existence very similar to Jack's.

Rex's final words stress Jack's integration within him, and recall Jack's decreasing determination by suggesting his own unwillingness now to determine Jack: “I don't need to dream [Jack's existence] any more" (p. 173). It seems that where Jack exists in the novel as a projection of the younger Rex, the older Rex in future might become a projection of the remembered Jack. That as products of historical, cultural, mythical, elemental, and linguistical forces they simply cannot be separated suggests that they form a microcosm of an integrated whole world. Moreover, the finality of tone that marks the ending and circle of their experiences is balanced by the novel's mirrored halves, circular structure and Rex's acknowledgement of the eternalising memory: "I've never forgotten Jack, and never will” (p. 173). The novel itself is, therefore, an integrated balanced whole whilst its greatest meaning lies in its interrelated parts. 


\section{CHAPTER 5}

\section{The Fat Man}

\section{Introduction}

That Gee followed the writing of The Champion with the writing of The Fat Man suggests his sense of filling space and capturing a defining period in New Zealand history in words. For in terms of timeframe The Fat Man follows The Fire-Raiser, with Gee quite consciously filling in the period between The Fire-Raiser's setting in World War I and The Champion's setting during World War II. As he has commented: "I thought I would go back and fill in another historical period with The Fat Man and that of course took in the Depression years, early thirties. I just wanted to get some sort of historical coverage of the times". Gee therefore sets The Fat Man in 1933-1934.

In many ways The Champion and The Fat Man are opposed. Each novel has two main characters. But where The Champion's protagonist is an aggressive child who interacts with a peace-loving adult, The Fat Man's protagonist is a peace-loving child who interacts with an aggressive adult. In The Champion the peace-loving Jack is a black American who spends time in New Zealand, and in The Fat Man the aggressive Muskie is a white New Zealander who spends time in America. Each adult character is childlike and a victim, and can be seen as a projection of the protagonist. Hence Jack is a hero whereas Muskie is a villain. Both novels are set in small town New Zealand in an area based on Henderson. But Kettle Creek in The Champion resembles Eden whilst Loomis in The Fat Man resembles Hell.

Muskie as the eponymous fat man is also comparable to Marwick as the eponymous fire-raiser. That the titles of their respective novels allude to them suggests their dominating roles. Both have had difficult relationships with unstable mothers and are mentally unbalanced. But Marwick is tall, hirsute, good-looking and intellectually impaired, whilst Muskie is obese, balding, ugly, and sly. A negative product of traditional British culture, Marwick believes he is a soldier; Muskie, a negative product of popular American culture, poses as a gangster. Where Marwick bears his scar on the inside and is an introvert, Muskie, an extrovert, wears his scar on his face. The claim made in the $O$ trilogy that it takes three to make things whole seems to apply to The Fire-Raiser, The Champion and The Fat Man which, as an integrated triad, seem to form a balanced whole. 


\section{Henderson: Past and Present}

In The Fat Man Gee includes several historical dimensions. Semi-autobiographical, the novel is deeply rooted in Gee's personal history. It is clear from Gee's memories of a youth spent in Henderson that it informs his depiction of the novel's township of Loomis and the events in which Colin becomes involved. The recourse to personal history is not a new technique. Many of Gee's novels for adults recall Henderson and the Depression period and, as we have seen, The Champion's Kettle Creek is based on Henderson and incorporates much autobiographical material. ${ }^{2}$ Born in 1931, Gee was too young to remember the early thirties, but he claims to know the period - "I just felt I had it all". ${ }^{3}$ Gee's security in his knowledge of the Depression is undoubtedly due in part to his father's and mother's stories. Together, then, personal and ancestral memories allow Gee to depict a convincingly realistic picture of small town New Zealand during the Depression.

Many of Henderson's real locations are actually named in the novel and still exist. Scenic Drive, where Colin's father attains relief work, is a road in the neighbouring suburb of Swanson; the Great North Road that connects Loomis to Auckland is a main route between Henderson and Auckland; and Millbrook Road in Loomis is a real road in Henderson today. Colin walks home down Millbrook Road with the creek on his left. On its downhill side behind the bushes the real Millbrook Road is indeed bordered by a tributary of Henderson Creek (see figure 1). Not far from the real Millbrook Road, Newington Road and the house at number 52 where the Gees lived in the 1930s, remains today (see figure 2). Sunnyvale Railway Station where the fat man catches the train to stage his return home recalls the real Sunnyvale Station, located off the Millbrook and Sunnyside Road conjunction (see figure 3).

Other places in Henderson, although differently named in the novel, are instantly recognisable. Mrs Muskie's daily route from Millbrook Road, past the jam factory, into town, and back to Loomis Station in Station Road can actually be tracked. Located on the corner of Railside Avenue and George Street, the old brick jam factory with ironframed windows today houses land rover dealers (see figure 4). The jam factory (recalled by Gee in "Creeks and Kitchens") is where Colin pauses on his way to school to look back towards the Potters' home. ${ }^{4}$ Gee has acknowledged doing this as a boy. Certainly, from the vicinity of the jam factory the Gees' home in Newington Road could be seen in the east, were it not for more mature bush. Loomis Station on Station Road is modelled on Henderson Railway Station, located on Railside Avenue (named Station 
Road in the 1930s, see figure 5). One can imagine Mrs Muskie waiting on the platform for the return of her the long absent son (see figure 6).

Loomis' Bellevue House (named the "Great Western" prior to Prohibition) - a centrally situated boarding house - is based on what today is named Falls Hotel. ${ }^{5}$ Built in 1854 by "Long John McLeod" (its first proprietor and a mill manager), the real hotel was intended as accommodation for workers at Henderson Mill. Situated on the corner of Railside Avenue and the Great North Road near the township's centre, it eventually became a boarding house. Re-named Central Boarding House in 1925, and Central Private Hotel in 1931 (about the time of the novel's setting), it was owned by a Steve Ozark. Gee has recalled the boarding house during the 1930s and 1940s. ${ }^{6}$ Sold in 1978 to the Norcross family, the hotel was gifted to the Waitakere Trust in the 1990s and shifted to its present site at the entrance to Falls Park. Fully restored, Falls Hotel is currently an up-market restaurant (see figure 7$)^{7}{ }^{7}$

Loomis' main creek and its tributaries are modelled on creeks that still cross Henderson. From beneath a wooden bridge at the foot of Millbrook Road, Colin and Muskie hear Mrs Muskie walking to Loomis Station. Merging with the Oratia Stream on the Millbrook Road, Dobson Street, View Road intersection, the real creek passes under a concrete bridge - presumably a new version of the model for the fictional one (see figure 8). In chapter one Colin crosses Flynn's orchard and a swamp to reach the creek. After joining the Oratia Stream at the bottom of Millbrook Road, the real main creek flows alongside Harts' Domain (which backs on to Newington Road where the Harts, Flynns and Gees lived). The orchards and swamplands that occupied this area during Gee's childhood would be the model for the fictional orchards and swamps (see figure 9). ${ }^{8}$ Colin observes the creek's "rushy islands and drowned willows" and follows its "rusty" waters to where it joins with the "main creek" (p. 10, see figure 10). Certainly the real creek at the point where the young Gee would have entered matches this description (see figure 11). Colin then turns up the creek to the water hole where he first meets the fat man, whilst the main creek flows on to the Dally vineyard. Located further downstream than the fictional water hole or its real counterpart (which Gee has claimed would now be dried up), the hole at Falls Park is probably similar (see figure 12) and indeed, the real creek flows on to Corbans' wineries. 


\section{The Creek}

Whilst retaining features of the past, 1930s Henderson has been seen as divided. Gee has referred to moving between the polarities of creek and kitchen as a child whilst others, along with Gee, have described their mixed feelings towards creek and home.

As Dick Scott has recorded, the creek was significant to many living in Henderson in the 1930s. Situated close to the railway line, it was a place of fun and danger where one might swim, fish, encounter a prowler, or hear the trains. It twisted into Henderson under the Great North Road and railway line, and ran on through orchards and the Mount Lebanon Vineyards (owned by the Corban family - immigrants from Lebanon). An older Corban family member has recollected that a favourite summer recreation for children "was to go swimming in the pool below the falls in Henderson Creek. Fresh water met salt [there] and sprats coming up in shoals with the tide were netted for the table and flounder were speared". But the creek was also a place of evil portent. Its eels were ferocious nibblers. To a child its surrounds were mysterious and sinister:

The night outside would, if no moon, be pitch dark. No street lights at all. Noises could be heard in abundance. Dogs barking (most folk kept watchdogs). [ . . . F From far away would come the unfamiliar cry of the morepork. [ . . ] Nearer at hand one's blood could almost curdle with the startling proximity of one of the unseen creatures, having winged utterly noiselessly to a nearby post and giving a sudden screech, making one think of ghosts. And along the railway line a few feet away, with its gorse and shrubs, and perhaps some hidden prowler, could come some unfamiliar sound. ${ }^{9}$

Gee, too, has recalled Henderson Creek and its surrounds: "In those days Henderson was a country town with its centre by the railway station. It was surrounded by orchards and vineyards. Corbans winery stood beside the hill road leading north. Dalmatians were everywhere. [...] We walked to school the roundabout way through the town. Just past the brick jam factory we looked back over the creek to our house". The creek was a place of potent significance to Gee as a boy. He remembers it in vivid detail:

Henderson Creek began at the dam and ended at Falls Park. We walked on its ferny banks, red mats of willow hair gave under our feet. [ . . ] The dam was half a dozen logs held together with rusty spikes. A tumble-down shed stood at the far side, with an iron wheel bedded in concrete. Someone had once made heel and toe plates there. It was a spooky place. Huge eels lived in pools on its lower side. On the far bank was a pit we could not see the bottom of. [...] In the afternoon we walked home along Millbrook Road. The creek was on our left. There was the swimming-hole where I learned to swim.

In swimming weather we went in classes down to Falls Park and swam in the brown salty water. The Falls and the dam were the two ends of my mile-long stretch of creek. The tide came up as far as the Falls. The green water changed colour. We spent our week-ends there, swimming, yarning in the grass, jagging sprats and kahawai. ${ }^{10}$ 
Most interesting are Gee's memories of the creek as a divided world that was delightful yet threatening, fun yet dangerous, and a place of tension where antitheses met. As recalled in adulthood the creek is very much the projection of Gee's divided mind:

\begin{abstract}
There was a creek in Henderson, one with deep slow-flowing dark-green pools. I seem to have spent half my boyhood beside it. My territory was a few square miles and the creek flowed in on one side and out at the other, coming from somewhere unknown, going somewhere unknown [ . . ]. The essential thing is a tension between what's familiar and what's unknown, between the safe place I had left and the dangerous place I was going to. At the creek was a dark/light division, never clear, never defined, and pleasure/pain, and allowed/forbidden. ${ }^{11}$
\end{abstract}

Gee most remembers the creek's danger. At the creek he met a real prowler with eyes that "did not blink [and] black eyebrows and a black unshaven chin". ${ }^{2}$ Indeed, Gee has acknowledged his fat man, too, as originating from an incident at Henderson Creek. He has recalled "being out on a walk in the bush with [his] mother and siblings and the shock of coming upon a naked man (what we would call a swagman) washing in the creek [and his] eyes locking with the man's intense black stare". ${ }^{13}$ Gee has described the impact the incident made on him:

I must have been 4 or 5 years old, just after the depression. My brothers and I were walking with our mother along Henderson Creek and came across a naked swagman we think he was a swagman - standing waist-deep in a pool, washing himself with a bit of yellow soap. I'll always remember the look he had. These dark eyes. He stood absolutely still and just watched us. That image surfaced when I was trying to get an idea for a children's story and so I thought I'd start with a character of that sort, down by the creek. ${ }^{14}$

Experiences of the creek were also responsible for Gee's initiation into less pleasant aspects of life. He has recalled nearly drowning in the creek. This and further incidents were to reinforce Gee's association of the creek with death, as he has explained:

\footnotetext{
Later, perhaps five years, we saw a man die. He dived into a shallow pool and broke his neck. We had been spying on him and his girlfriend on a blanket. We had wanted to see sex but saw death instead. And others died. Four children, brothers and sisters, all drowned together. [...] And years later a man killed a woman and tried to hide pieces of her body there. ${ }^{15}$
}

\title{
The Novel
}

Henderson Creek is clearly identifiable in The Fat Man. For Colin Potter, as for Gee and others, it is a place divided unevenly between fun and danger, with an emphasis on danger. Here, in an old hut constructed by his father, Colin imagines adventures or hears passing trains. But, located in a gorge, the creek exists in a darkened world. To Colin it has terrifying noises: "Cats screamed down by the swamp" (p. 49). There are 
biting eels: "There's big eels down there. They'll have your foot off with a single bite. And your willy" p. 29). And there are deep pools of "green slow water" (p. 11). And it is here that Colin first meets the fat man who strongly resembles the real swagman recalled by Gee: "He [... ] had his first sight of Herbert Muskie, standing waist-deep in the creek. $[\ldots]$ When the soap jumped from his hand he submerged again to pick it up. He put the yellow cake between his teeth $[\ldots]$. His eyes were angry. They were small and deep and blacker than sheep pellets" (pp. 11, 14).

Like Henderson Creek, Loomis Creek in The Fat Man is repeatedly associated with death. In chapter one Colin is "too scared of the dark parts of the creek to swim alone" (p. 10) and is terrified when he falls in: "Halfway across a layer of rotten bark sheered under his foot and he gave a screech and fell sideways into the water" (p. 29). In chapter six Verna almost drowns in the creek: "Verna went down sideways, then head first, into the creek. She vanished under the green surface but popped up like a cork, with her hair flattened on her skull" (p. 93). And in chapter seven Colin finds Mrs Muskie who has fallen into the creek and drowned: "Mrs Muskie came into view, with the top part of her body floating face down and her arms hanging deep in the water as though she were reaching for her sovereigns down there. Her legs were deep down too, in the green pool, lit with the dull gleam Colin had seen" (p. 105). Like Henderson Creek, Loomis Creek is a predominantly dangerous place where antitheses meet and tension arises.

\section{The Home and Family}

In contrast to the creek, the typical Henderson home offered security and comfort. An older Dr Corban has recalled his childhood home in Henderson and its "warm kitchen". ${ }^{16}$ Gee's memories of a secure childhood home are also vivid. Like many houses of the Depression years, it had a "kitchen with wood range. Zwieback in the oven. Stew with doughboy bubbling in a pot. Work socks drying on the wire rack and the chimney roaring. Meat safe on the back porch, copper and wooden tubs in the wash-house, two red watertanks on a stand, and the dunny up the path behind the hedge". ${ }^{17}$ Gee remembers his "mother at the stove", and the stability and comfort she provided. ${ }^{18}$

Gee has recalled that his father was a "doer" with "practical skills [such as] building and making and garden-growing". ${ }^{19}$ A carpenter, Len and his sons "made the most of their access to tools and materials for making boats for paddling down the creek to Waitemata Harbour". ${ }^{20}$ Indeed, Gee's father apparently "sawed and planed in his workshop. Sparks from the emery wheel played on his hands. At picnics he won 
the nail-driving contest - three smacks and the nail was in. With his mate Tom Cryer he raised a new wall in a house; and with his Skilsaw cut through lumps of four-by-two like butter". ${ }^{21}$ Gee remembers how his father brought "the heroic" as well as "the practical" into their lives. Referring to his father as "Laurie" (possibly a nickname), he has recalled that "Laurie, my father, was a very good amateur boxer and he won a stack of cups which they had to sell in the depression. [ . . ] He used to tell us marvellous stories about the men he knocked out in the ring". Gee has noted his father "was not a violent man but he was tough and proud and he wanted his sons to take after him. He had knocked out men with names like Jack Bishara. We were thrilled by the details - the blood on the gloves, the deadly combination of straight left, right cross. We did our best to live up to him". Apparently comrades, Gee and his father practised combative skills: "We wrestled with him on the lawn. We gave him the hammer-lock and the Chinese burn until he howled for mercy". 22

For Gee there seems to be a reassuring quality to the domestic scene, as there also is to the street, Henderson, and the Waitakere ranges, clearly seen in the west. About these origins he has commented:

\begin{abstract}
Remembering these things makes me want to write stories. [ . . ] I want to put them into lives and demonstrate their continuity and the primal quality they have. That kitchen is "kitchen". I hear the word and I have that place. House is that house. Street is Newington Road. Valley Henderson Valley. Hills the Waitakere ranges. [ . . ] It's where important things happen. The original happenings that make the mark on us we can never erase. ${ }^{23}$
\end{abstract}

But Gee has noted that home life and Henderson were not so "neat and tidy". In fact, there were conflicting elements within the domestic scene as there also were within the world of the creek. Seemingly these threatened his ideal of home as eternal: Dad, a "hero, who had been a boxer [had] knocked men out. Mum, writing poems in exercisebooks and reading Krishnamurti", talked about the Depression. As Gee has acknowledged, the climate of the times was:

\footnotetext{
A mixture of much that was real and much unreal: political idealism, political action, liberal behaviour [...] family loyalty, a sense of being special in birth, a pervading religiosity and free-thought along with it, and haunted places and kitchen security, and puritan idealism, and belief in Man, in perfectibility. [...] Ours was a very masculine household but with a presiding feminine spirit. ${ }^{24}$
}

Thus home and family for Gee was almost as mixed as the creek, although in relation to the creek as a world mainly of danger, it represented mainly what was safe. As Gee has acknowledged, the creek and the home or kitchen were the poles that he moved between for most of his childhood. ${ }^{25}$ 


\section{The Novel}

Like the Corban and Gee homes, the Potters' home in The Fat Man is a place of warmth and security. Recalling the Gees' home: "The kitchen [is] the living room as well, with two bedrooms opening off and the bathroom and the wash-house sharing a lean-to out the back" (p. 47). Like Gee's mother and father, Colin's parents implement comfortable routines. In chapter three his mother sits in the kitchen "at the table darning socks with wool she had unravelled from an old cardigan" (p. 41) and in chapter eight she takes a "plate from the oven and [puts] it in front of him: doughboy and stew" (p. 121). Like Len/Laurie Gee, Laurie Potter is a "doer" and carpenter. He chops wood, belongs to a rugby club working-bee, and digs the garden: "Colin looked out the window and saw him digging in the garden. The clods of earth shone where the spade had sliced them and his father's forearms gleamed with sweat" (p. 41). Where the young Maurice idolised his father the boxer, so Colin sees his father is a boxing hero. He has won medals, a plated belt and, as Colin proudly tells Muskie, "the Auckland championship, for welterweight" (pp. 26-27). Like the young Gee, Colin practises combative skills and in chapter three suggests a mock fight: “'Let's do gunfights, Dad.' They put [the sixshooters] in their belts and faced each other across the brown lino of the kitchen" (p. 47).

But like Gee's memories of his real home, the fictional home has its unpleasant features, some reminding Colin of mortality. Colin is constantly hungry - his mother says he has "a hole in his stomach" (p. 9) - a joke that Colin notes she has "hammered to death" (p. 9). Far from the nourishing food Gee ate as a boy, Colin is given "hard food for hard times" (p. 9). In addition, Colin's father as a boxer has "knocked men out, with a right cross sometimes, or a left hook [and has] flicked too hard" (p. 43) in fun fights with Colin. Furthermore, Laurie's boxing cups, like those belonging to Gee's father, are sold during the Depression, with the family gaining six guineas from a travelling hawker. Altogether in The Fat Man, then, Gee paints a picture that is certainly true to life as seen by himself and others. It sets the dangerous creek world against the secure domestic world and shows each of these worlds to be further divided.

\section{Social Structures}

Impoverishment during the Depression caused familial roles to level out, sometimes in a positive way. Friends would help each other, often showing unprecedented generosity. In The Sugarbag Years, Tony Simpson records an interviewee's reminiscence: "I went to his place and there were no carpets on the floor, they'd all been sold, instead they had potato sacks. The table had no tablecloth, it was bare. They had some plates, they had 
no saucers. They brought out half a loaf of bread and this was the welcoming meal for me. [ . . . ] Now, that's the kind of thing I saw in the Depression. Human beings helping each other. Humanity coming through", ${ }^{26}$

The Gees seem to have been a close-knit family. Interviewing Gee, Judith Holloway has referred to "the tolerance towards old people who were going a bit dotty" but who were not "stuck in a home". Gee replied: "The extended family was much more common among the pakeha than it is today. [...] We had my father's father with us for a while". Gee's maternal grandparents also lived nearby, and he visited them for food: "Over the road from the dam was Peacehaven, our grandparents' house. We were told not to ask for anything to eat, but we asked and our grandmother had a biscuit or a piece of bread and jam for us". ${ }^{27}$

But the Depression often had a negative effect on families. The family of former New Zealand Prime Minister Robert Muldoon was no exception. That it may even have been a source for Gee's depiction of the Muskies suggests a brief examination of it could be useful. Since the age of eight Muldoon was brought up without a father. According to Jon Johansson, stress resulting from syphilis and a business collapse during the Depression caused the father's serious physical and mental defects which in turn led to his incarceration in an asylum. ${ }^{28}$ Teased about his father at school, the young Muldoon was raised by a strong-willed, fawning mother and grandmother who spoilt him emotionally. Although extremely intelligent, Muldoon had a facial defect, sharp eyes, and an over-large head and shoulders, which made him different, insecure, and an outsider. These influences together with poverty caused Muldoon to see life as a struggle against malevolent forces he needed to control. Certainly, as Prime Minister from the late 1970s to early 1980s, Muldoon held his cabinet in what Johansson has aptly described as a "vice-like grip" through manipulation, bullying and combat. ${ }^{29}$ His entrenchment in an arcane world view, and a stagnant economy triggered nearDepression conditions. Johnansson notes that when Muldoon lost to Labour in the 1984 elections he was drinking heavily, diabetic and overweight, and with his mental skills declining. As we shall shortly see, parallels exist between the Muldoons and the Muskies.

The levelling of familial structures during the Depression was paralleled by levelling social structures. The government's concern with balancing the budget meant stringent cost cutting and widespread hardship forced people to work together in order to survive. As described by Tony Simpson: "Shopkeepers went bankrupt in droves [and] 'chippies' were walking the streets searching desperately for any sort of work". With so many sharing poverty the traditional class divisions of a British heritage 
crumbled. As Simpson put it: "All the petty social distinctions were swept away, the lies and pettyfogging and humbug. Everybody over vast areas in town and country was on the bare bones of their arses, and there was no pretending otherwise". ${ }^{30}$

\section{The Novel}

In The Fat Man Gee depicts the positive effect of the Depression on families. Like the Gees, the Potters are close-knit and help each other out. When Colin acquires a shilling from Herbert Muskie, he offers it to his mother for housekeeping, and he chops wood and digs drains with his father. Recalling Gee's maternal grandparents, Colin's grandparents live separately and provide meals the Potters cannot afford. Their Sunday roasts with "meat and gravy, roast potatoes, jelly and blancmange and a glass of milk" (p. 10) make a welcome change from Colin's normal diet of "mince stew, and not enough of it, and curly kale, and a spoonful of mashed potato without any butter, and [...] bread pudding [or] sago" (p. 9). Maisie regards her husband's parents as family and refers to them thus: "He was her father-in-law but she called him Dad, and her mother-in-law Mum" (p. 42). Colin too acknowledges his affection for his Grandfather: "He loved his grandpa, with his skinny throat and hairy ears and knotted hands" (p. 52).

But Gee also shows the Depression's negative effects. Indeed, the Muldoons are strongly recalled in the Muskies. Like Muldoon's father, Muskie's father has been physically weak, has experienced business failure during the Depression, and has died as a result. Thus he is "a little weaselly man [who drops] in his office, with invoices looping from his hands" (p. 22). Like the young Muldoon, Muskie has been brought up by a fawning mother who has struggled to make ends meet, and is teased and ostracised at school. Recalling Muldoon's facial defect, gimlet eyes and obesity, Muskie's cheek is disfigured with a worm-like scar, his eyes resemble "sheep pellets" (p. 14), and he is certainly fat. Intelligent, an outsider, abrasive, and manipulative, Muldoon is recalled in the intelligent Muskie, an outsider at school, and in adulthood manipulative, intimidating, and physically and mentally holding others in a vice-like grip. Whilst Muldoon's childhood occurred during the Depression, and Muskie's occurred prior to World War I (when he was old enough, but too obese, to be conscripted into the army), it is the Depression that exacerbates the adult Muskie's negative tendencies. These and their similar names (the last and first syllables of their Christian names and surnames respectively are identical) suggest Gee may have seen Herbert Muskie as a sort of fictional precursor to Robert Muldoon. 
The flattening of social structures that occurred during the Depression is reflected in the novel. Grandpa tells Colin how he once worked at the Muskies' house where as a drainlayer he did not "get past the back door" and where "all them girls in frills and frocks lookin' out the windows, high up like and holdin' their noses" (p. 53) looked down on labourers. But in the novel's setting in 1933 an insecurity of status typifying Depression years is presented. Colin's family has gone up in the world - Grandpa and Grandma run Bellevue - whilst the once well-to-do Muskie family has fallen into poverty:

\begin{abstract}
The Muskies had been an important family once, but nobody was important now, not in Loomis. Most people were broke and most of the men were on relief. Shops were boarded up in Station Road. Mrs Muskie owned most of them, but now she only got rent from the grocer and the butcher. The only one of her businesses still going was the sawmill, and that was on its last legs. (pp. 21-23)
\end{abstract}

Consequently those girls who once looked down on Colin's Grandpa, reduced by Depression conditions, enter Bellevue as parodies of the upper classes. As Herbert Muskie says, "Me lovely sisters. [ . . . They don't come to see their ma for ten bloody years. But when they hear I'm home they're out here in a flash to look after her. Real queens" (p. 98).

Gee's depiction of the Depression as a time of slump and change emphasises the period's contradictions - the exchange of roles and responsibilities traditionally associated with male and female, and adult and child; the fall and rise of upper and working classes; and the mixture of humanity and desperation. Gee's portrayal of these suggests his interest in division.

\title{
Conformity and Control
}

In 'Fretful Sleepers" Bill Pearson notes New Zealanders' obsession with conformity, utilitarianism, mateship, equality and security, and its norm-ridden society. $\mathrm{He}$ comments: "There is no place in normal New Zealand society for the man who is different". ${ }^{31}$ Although in some respects the Depression resulted in a levelling process, conformity to old codes of behaviour, and temperance and linguistic propriety were often maintained.

Behavioural codes were certainly enforced in the Gee family. Gee has recalled his mother's gentle control: “Ours was a very masculine household but with a presiding feminine spirit. We did not forget good manners and what was owed to women. 'That's not a table topic,' my mother used to say". ${ }^{32}$ The picture of a mother who exercises linguistic propriety is confirmed by Gee's further reminiscence: “There was a swimming-hole where I learned to swim. A beautiful grown-up girl dived off the over- 
hanging willow branch and came up shouting, 'Who said you can't touch the damn bottom?' 'Mum, I thought you said ladies don't swear.' 'Well dear, she isn't a lady'”.33

There was also the generation gap. Responding to Judith Holloway's reference to "the primness, the general reticence about discussing certain things, not 'making a fuss', [and] the big gap between kids and adults" that typified the 1930s, Gee has affirmed his family's authoritarian structures. He remembers his paternal grandfather's belief in corporal punishment: "He was a tough old bugger, drove my mother mad. [...] And he was always on about kids needing hidings. [...] A kid needed a hiding to smarten him up, set him right". And he has described his father's enforcement of good behaviour: "It was still heavily authoritarian in those days. That didn't mean there wasn't a lot of fun going on in the family. But Dad would snap his fingers - go to bed and you went". Gee remembers corporal punishment received from his father: "When we had been naughty he punished us. We watched from the bathroom window as he cut a willow stick from the hedge by the dunny. [ . . ] That willow stick raised welts like chains of mountains on our legs". Gee also received "the cuts" at school, and proved his toughness by winking at his "cobbers" on his way back to his desk. ${ }^{34}$

Perhaps because of the Depression's levelling effect, dress became more uniform. Many children went to school barefoot, and where shoes were worn they were sandshoes. The Sugarbag Years records one person's experience: "We had no shoes, but for footwear sandshoes were the thing because they were the cheapest of the lot". Those who wore something different could be ostracised or worse, as a witness has described: "I remember one chap who used to come to work in a reasonably decent suit and the crowd used to poke fun at him. [ . . ] He was a man who'd had a pretty decent sort of life and had come down in the world and he'd fallen a bit further than a helluva lot of us had fallen. [ . . . T The last I heard of him he'd committed suicide, he just couldn't take it". ${ }^{35}$

In Henderson during the 1930s and 1940s, the young Gee certainly experienced a conformist society. He has recalled that in winter everyone "ran to school bare-footed" and bullying a boy who was fat: "I remember incidents with our school fat boy. He was bullied and tormented. I remember taking part in one episode. It comes back to me, the feeling of shame". Gee has described another similar episode: "We beat up Fatty Walker for peering through a hole in the girls' changing shed. Our rage was made up of moral indignation and bitter envy. Fatty had done what we longed to do. We punched him without mercy and his blubbering fulfilled us". ${ }^{36}$ 


\section{The Novel}

In The Fat Man we seem to be back in Pearson's norm-ridden society. Like Gee's mother, Maisie enforces right behaviour and linguistic propriety. She insists Colin chew his food thirty two times (p. 9), does not "believe in nick-names" (p. 45), disapproves of saying “ain't" (p. 47), only kisses Laurie in private (p. 49), and is reluctant to bike-ride on Sunday. When offered beer by Muskie, she and Bette abstain (p. 66).

Gee depicts conformity to behavioural rules. Recalling Gee's paternal Grandfather and father, Colin's Grandfather has administered corporal punishment in the past. In chapter three Colin's Grandmother remembers the "proper tanning” Laurie received "for nearly drowning Herbert Muskie", and how "Harry whipped him [ . . ]. Cut a willow stick right there, really made him bawl" (p. 51). Mr Muskie has whipped Herbert, who remembers getting "the old willow stick [...] from the old man" and also getting the strap at school "every day for a year" (p. 24). Itchy Edgar continues to strap the children of Colin's generation.

Gee stresses that a lack of conformity is sometimes necessary. Recalling Henderson School, Loomis School in 1933 has children dressing the same. Like the young Gee, Colin goes to school barefoot. In chapter five his reluctance to accompany Verna to school is because she is different, with little hair and atypical clothes. Colin knows that bullying from the Rice and Settlement gangs of tough boys and girls will result: "Colin could not believe the way Verna was dressed: a pink dress, frills, red shoes, white socks. She carried a little brown polished case instead of a schoolbag. [ . . . ] They would do more than tease, Colin knew, and not only because of her hair" (p. 76).

Colin is adept at fitting in. He deliberately achieves a middle mark in a test to avoid sitting at the front or back of the class: "Colin always tried to finish halfway in the test so he would not have to change his seat by the window. So he got two sums wrong and four of the mental and four spelling words. [... ] Itchy read the placings out and people cleared their desks and shifted round" (p. 80). But Gee emphasises that not taking sides and avoiding extremes do not equate to balance. By having Colin place himself alongside Verna and protecting her against the school bullies he suggests that an extreme stance is sometimes necessary to right the balance.

In Loomis those resisting conformity are punished. Colin and Verna are harassed by the gangs and, much as Gee and friends bullied a fat boy at school, Laurie, Maisie and school friends have bullied the fat Herbert Muskie in the past. In chapter eight Muskie describes how twenty-five years earlier they made him eat "spit sandwich" (p. 134) and how Maisie and her friends ridiculed him: "We had to go for swimming, from 
school. The girls would be standin' round when I came out of the shed. [ . . ] They only laughed” (p. 134). Sometimes bullying was close to torture. Colin's Grandma recalls the Empire Day picnic at Cascade Park when Muskie was nearly drowned: "He was swimming out in the deep part of the pool and the other boys dived underneath and hung on his legs. Little hooligans. If some of the men hadn't seen ... They had to pull him out and give him artificial respiration" (p. 51).

Gee therefore gives us a whole view of Muskie that explains his bullying of Colin, and that clearly emphasises that bullying and conformity are wrong. He portrays a version of small-town in the 1930s that many New Zealanders will recognise from their own experiences. This, combined with other trends during the Depression, contributes to the national character that many (especially Gee) see as conformist yet deeply divided.

\section{Prohibition}

Prohibition as depicted by Gee contributes to the New Zealand character's conformity and division. It originated in New Zealand when the first Temperance Society was established in the Bay of Islands in 1836. ${ }^{37}$ Other organisations joined in the fight against "the demon drink", and the New Zealand Alliance was formed in 1886. In Looking Back: A Photographic History of New Zealand, Keith Sinclair and Wendy Harrex have noted that prohibition "must have been the most powerful reform movement in New Zealand history" and that it was only the vote of New Zealand's thirsty soldiers in 1919 that prevented it from becoming law. ${ }^{38}$

In Henderson, however, prohibitionists had their way. Dick Scott records in Pioneers of New Zealand Wine that "in 1908 the prohibitionists registered their first victory in wine districts when Masterton and Eden (an Auckland electorate including part of Henderson) voted no-licence". Those living in Henderson must have been acutely aware of prohibition's impact on the region, for Henderson was divided in two, with the railway line providing the boundary between wet and dry areas. Moreover, by-laws related to prohibition were absurd. Scott documents the bias of Sir Robert Stout, chief justice, well-known prohibitionist and man of "blue-ribbon views", who declared in court that "not only could a winemaker not sell wine but also, in his opinion, he could not even make wine in a no-licence area". The Crown Law Office published a statement in the Journal of Agriculture quoting Stout's judgement, and went on to contradict it:

There is nothing, however, to prevent [ . . ] a person manufacturing wine from grapes grown in his vineyard in a no-licence district; and there is nothing to prevent him establishing a depot or cellars anywhere outside the boundaries of the no-license 
district, and removing all wine manufactured to that depot. If he does that he can sell his wine from that depot to customers, whether they reside in a no-license or in a license district. ${ }^{39}$

In West Auckland as a result of Stout's ruling, five hotels between Henderson and Auckland closed, including Henderson Falls Hotel, which had its final day of business on 30 June $1909 .^{40}$ To circumvent the absurd by-laws, winemakers erected depots in Henderson's wet area to sell wine grown in its dry area. Interestingly, the railway line marking the boundary between wet and dry areas also marked the front boundary of the Corban family's vineyard. Assid Corban circumvented this problem by opening a "sly grog shop" in a railway man's cottage on the wet side of the railway line, only a few yards away from his wine cellars on the dry side. ${ }^{41}$

Prohibition was, of course, a phenomenon particularly associated with the United States. However, the very laws meant to save society from the evils of liquor often resulted in an increase in drink and crime. In America sly grogging, illegal distilling and brewing, smuggling, and organised crime thrived. ${ }^{42}$ As noted in The Detroit News, for example, Michigan was “a bootlegger's dream”. In 1929 illegal liquor was its second biggest business (after automobiles). Thus illegal drinking occurred in Michigan's 25,000 blind pigs, numerous speakeasies, private clubs, restaurants, storefronts and homes. Accordingly the Detroit River (forming the border between Canada and the United States), frozen in winter, in some places less than a mile wide and, with its twenty eight miles containing thousands of hiding places, was ideal for the smuggling of liquor. The Detroit News described the mayhem ruling the river - the violent gangs, kidnapping, prostitution, gambling, and murder. ${ }^{43}$

\section{The Novel}

Prohibition in Loomis recalls prohibition in Henderson some twenty-five years after the 1908 ruling. As previously noted, Henderson Falls Hotel is replicated in the boarding house belonging to Colin's grandparents which Muskie recalls thirteen years earlier as a "pub with no beer" (p. 16) called The Great Western. Changing its name to Bellevue House since Loomis had become dry, it still has "the beer names printed [ . . ] in gold letters" (p. 54) on its windows in 1933, whilst its private and public bars remain locked. Grandma Potter enforces the legal requirement of drinking in private, and in chapter seven when the fat man proposes a celebratory funeral drink, comments: "I don't like beer-drinking in front of children" (p. 112). In chapter two Muskie outlines experiences typifying Detroit's prohibition era: 
I drove trucks full of bootleg hooch across the ice from Canada to Detroit. I seen a man - you want to know? - we wrapped chains round his legs and dropped him down a hole in the ice. One night, up there. And I seen a truck go down with its lights still shining, right down to the bottom before they went out. On Lake Eyrie. (p. 26)

In chapter four Muskie confirms that during the prohibition era he spent ten years "in the liquor trade" in the States transporting "bootleg hooch" by truck and boat from Canada (p. 60). Grandpa's subsequent reference to "speakeasies" (p. 61) suggests his familiarity with illicit liquor shops, and anticipates his eventual collaboration with Muskie in the illegal sale of liquor in Loomis. Where old man Corban established a sly grog shop just inside the legal boundary (on Henderson's wet side), Muskie and Grandpa establish a sly-grog shop outside the legal boundary: "He and Grandpa set up a little sly-grog shop, working out of a shed at the disused mill. The fat man brought crates of beer from Auckland in his car $[\ldots]$. He carted the beer and took the profits while Grandpa, on wages, did the selling" (p. 103).

The theme of prohibition contributes to a divided Loomis. Not only are there wet and dry areas, but also there are those who conform to the law like Maisie, Bette, and Grandma Potter, and those who break it, like Laurie and Grandpa Potter, and especially Muskie. Gee suggests that whilst an extreme stance will sometimes correct society's imbalance, some behavioural extremes are wrong. Whilst conformity to authority, including the law, can be ill-advised, sometimes it is essential.

\section{Breakdown}

Whilst the Depression was sometimes marked by more humane attitudes, there can be no doubt that poverty was degrading and could drive people to violence and crime. As Tony Simpson records, some, normally living decent lives, resorted to stealing: “A fellow who had tuberculosis [... ] couldn't get work, he was too sick, but he had a wife and kids and he couldn't see them starve, so he went and stole something or other". Others racketeered: "This bloke who was on relief [...] was in his kitchen one day and I saw into his cupboard and it was absolutely packed with food. [ . . . I f found out later that he had a friend in the relief depot and there was quite a racket going". Still others felt debased by cruel work conditions: "The farmers generally treated us like animals and we were quartered like animals. [The] converted cow byre $[\ldots]$ was just full of fleas and most uncomfortable to live in, and the food was atrocious. The place was crawling with maggots".

With widespread unemployment many took menial jobs like one "trier" who went "round hundreds of houses wanting to sharpen knives, clean windows, fix taps" and 
who eventually made cushions and "hawked them around the houses and in and out of shops". Relief work was particularly demeaning and underpaid. Often driving men away from homes, it required them to live in camps notoriously "primitive, almost barbaric in some instances". In 1932 in Auckland and Wellington mass protests developed into mob riots. The unemployed turned against the police: "Queen Street was looted from end to end. Law and order were down and out. [...] The looters, being ordinary decent citizens moved to desperation by distress, exploded in violence". At its worst, then, the Depression destroyed what was precious to life. ${ }^{44}$

Gee has described the Depression as "a hairy beast devouring people". ${ }^{45}$ It was something that he came to know as "Enemy". He has recalled his father "[riding] off with his tool kit on the bicycle handlebars, desperately [chasing] work in those hard times" and his mother as "a strong Labour Party activist [whose] sympathies lay with the relief workers and unemployed". A thinker and storyteller, she taught Gee much about the poor and needy: "Mum used to tell [ . . . ] marvellous stories about people's hardships in the depression when they couldn't manage to pay the rent, that sort of thing". ${ }^{46}$ Undoubtedly she would have taught Gee about the relief camps nearby in the Waitakere Ranges where workers were constructing Scenic Drive.

\section{The Novel}

In The Fat Man Gee shows how social imbalance - the breakdown of behavioural, familial, and legal structures during the Depression - leads to mental and moral imbalance. Coming upon the fat man's gear in his hut, Colin is driven by hunger to crime: "It was okay to pinch from a burglar, he supposed. There wasn't any money [ . . ]. Then he noticed a pocket on the front of the rucksack and slid his fingers in and brought out a penny cake of Nestle milk chocolate $[\ldots]$. A shiver of delight ran through him the taste" (p. 13).

The Potters are demeaned by the Depression. Grandpa does menial work framing doors and clearing drains. Recalling Len/Laurie Gee, Laurie Potter chases work on his bike: "He followed Muskie's timber truck every morning on his bike, with his toolkit slung on the handlebars, and he got jobs that way [ . . ] stacking timber, labouring, maybe framing up" (p. 44). When Maisie sells Laurie's boxing cups for a few guineas she knows sadness and shame: "Mrs Potter sat down at the table. She pushed the money away and put her head on her arms and cried" (p. 46). Working for the fat man, section-clearing, painting, plumbing, drain-laying, and smuggling, Laurie sells his soul for the sake of "good wages" (p. 75). Perhaps the most degrading work the novel 
depicts occurs prior to its setting in 1933. Like real relief workers in the Waitakere Ranges, Laurie has been involved in constructing a scenic drive, but terrible conditions cause his departure after three months: "[Colin's] father was on relief, working in a camp up in the ranges, where they were building a scenic drive $[\ldots]$. His father had stayed in the camp for almost three months until he walked out of it and came back home" (pp. 43-44).

Gee depicts both sides of the situation. Obviously sympathetic to the Potters as "ordinary citizens" caught up in circumstances beyond their control, he sets them against Muskie who is cunning, mercenary, and murderous. Muskie exploits his mother by stealing her sovereigns and the public by smuggling liquor and selling stolen goods. He also sexually exploits Bette and Verna. But Gee's view of Muskie is mixed. Muskie's murder of his mother and reduction to a snivelling child place him in a position more abject than that of any other character in that the Depression has pushed him so far down he finally pays with his life. Gee therefore reduces the complexity of history and, whilst emphasising characters as mixtures, sets those that are mainly "good" against Muskie who is mainly "evil". Furthermore, through Muskie's breakdown Gee explores what remains fundamental to the national character once social norms are destroyed.

\section{Cultural Divisions}

During the Depression entertainment provided an outlet for misery. Gee echoes the period's cultural divisions and sets traditional British culture against popular American culture. Tony Simpson has described popular imported American culture and its influence on New Zealand:

\footnotetext{
What events of the Depression and the succeeding Labour Government did was to free radio broadcasting [ ...] from the constraints of both elitism and commerce so that they became potential vehicles for the expression of the preoccupations of the broad generality of the population in their own vocabularies, that is, of popular identity-carrying culture. ${ }^{47}$
}

Simpson has noted that, following government control of radio programmes prior to the 1931 election, they comprised mostly "popular dance and light classical music recordings" which (along with American movies) included little that was overtly politically contentious. The Sugarbag Years describes the popularity of radio and sentimental song. One interviewee has recalled "those great old songs of the day: Happy Days Are Here Again". ${ }^{48}$ A Corban family member has similarly recollected "the thin, faintly disembodied sounds of a gramophone horn" that played the American tunes, "I Want To Be Happy" and "I Must Go Home Tonight". 49 
Popular music was also brought to people in the 1920s and 1930s by gramophone, vaudeville, and movies. On Boxing Day 1929 New Zealand's first season of talking, coloured movies marked the beginning of the end of vaudeville. Becoming the most popular form of entertainment, imported movies and the picture palaces provided another escape during the Depression. ${ }^{50}$ Indeed, Khaleel Corban has recalled the romantic silent motion pictures for which he operated the projector fortnightly in Henderson's village hall. ${ }^{51}$ American comedies, westerns, and gangster movies were favourites.

Gee remembers the influence of American culture on his childhood. During the Depression years he listened to the radio, and avidly read the thirty or forty Zane Grey westerns in his high school library. ${ }^{52} \mathrm{He}$ has recalled "the Henderson pictures on Saturday night, Abbot and Costello and Alan Ladd", the British comic book character Rockfist Rogan, and Grey's American cowboy hero Buck Duane: "I had flown with Rockfist Rogan over the coast of France and ridden into the badlands with Buck Duane". ${ }^{53}$

\section{The Novel}

In the novel Gee shows the waning interest in English culture and increasing interest in American culture as typifying the Depression. It is mainly the older generation that still believes in the traditional British class system and royalty. Colin's grandma remembers "Empire Day picnic at Cascade Park" (p. 51) and "Buckingham Palace" (p. 53). And photographs of royalty adorn Bellevue's dining room walls: “The King and Queen hung smiling on the wall, and Queen Victoria with her red-coated soldiers, and pretty girls in white gowns leaning on Greek columns, looking across a blue lake at a pink sky" (p 57).

Muskie, Bette, and Verna bring American culture into Loomis. Together Verna, whose parents used to perform in vaudeville, and Bette, who used to "sing on the stage [in] musical comedy" (p. 66), represent the end of the era preceding the motion picture. Performing for Muskie at Bellevue, Bette sings typically sentimental numbers like “Happy Days are Here Again" (p. 67), and later at the Muskies' house "Whistle While you Work" (p. 87). Muskie also alludes to American popular songs. He names Bellevue after the song "The Pub with no Beer", previews Verna's haircut in chapter seven by whistling “Three Little Words" (p. 117), and at his mother's funeral requests that Bette sing “Old Fashioned Mother" (p. 112).

Like the young Gee, Colin listens to the radio, is familiar with American movies, and attends screenings in the village hall: "He went to the pictures in the town hall (when he 
could scrounge a few pennies from his mother)" (p. 21). In chapter three he enacts a western with his father, whilst he sees the fat man alternately as a comic character wearing “a Laurel and Hardy jacket looking ready to burst" (p. 40), and as a gangster:

\footnotetext{
He [Muskie] took his jacket from the ferns and shook it out and put it on. It made him look even bigger. He took a tie from the pocket and knotted it round his neck. Then he put his hat on, careful not to disarrange his hair, and flicked the back brim up with his fingernail and turned the front one down on an angle. Now he looked like a gangster. (pp. 19-20)
}

Newly arrived from America, Muskie imitates the gangster's style and speech. He wears a slouch hat, drives a Buick, and in a "voice he [has] picked up in America" (p. 14), uses gangster slang. As Colin learns upon first meeting, Muskie's mannerisms and gangster voice are terrifying: "The fat man smiled. He winked. 'Okay, kid. I like "please". You gotta learn these things. Life's a school of hard knocks, they say" (p. 18).

Gee's selection of real but contrasting detail from history suggests his interest in a truth that is never one-sided. Loomis is divided environmentally, socially and culturally. Conformist and stagnating during the Depression, it contains extremes and is caught up in change. Thus The Fat Man is a realistic representation of a complex period in New Zealand history that, like the individual, is suspended between two wars and worlds the old and the new.

\section{From History to Fiction}

Gee has acknowledged that things in his books "get charged with significance [and that] there's a lot of making pregnant". ${ }^{4}$ An examination of the differences between real history and The Fat Man suggests that the novel reduces the complexity of history in order to emphasise contrast. For instance, there are discrepancies between Gee's childhood landscapes and those in the novel. Most obviously Henderson becomes Loomis, a name Gee chose for its resonance: "[I] chose Loomis which I think is a wonderfully evocative name. It's got 'loom' in it and it's also got a suggestion of doom in it, and things of that sort. It's also something that seems to go back in time". ${ }^{55}$ Similarly, Henderson's Falls Domain is re-named Cascade Park, and Gee alters features of the real creek and its surrounds. Where Khalil Corban recorded the creek's howling dogs and moreporks, Gee adds the cats' screeching to the noises Colin hears. And the vineyard bordering the creek, in real life owned by the Lebanese Corban family, becomes the "Dally" vineyard owned by Dalmatians.

Further differences are evident between the real and fictional meetings with the man washing in the creek. Where the real man was a swagman (and probably grubby), the 
fictional man, as Colin realises, is apparently not a swagman and obsessively clean: "The shirt smelled of soap not sweat and looked as if it had been properly ironed. The man did not seem to be a swagger" (p. 12). Where the real man was definitely "not fat", the fictional man's obesity is repeatedly emphasised. ${ }^{56}$ And where Gee and his mother hurriedly withdrew from the incident, Colin lingers and becomes embroiled in the fat man's schemes.

The domestic environment and characters - their names and roles - are also changed. Henderson's historic Falls Hotel is named in the novel's past The Great Western, and in its present, ironically, Bellevue. Interestingly, it is not Gee senior's birth name Len, but his nickname Laurie, that is given to Colin's father in the novel whilst the playground gangs from Gee's childhood change from Army, Navy, and Airforce, to Rice and Settlement. Gee seems to draw on his irascible but likeable paternal grandfather in order to construct the character of Grandpa Potter. But it is the visits to Gee's maternal grandparents' home for food that provide the basis for the depiction of Colin's visits to his paternal grandparents' home.

By adding the screeching of cats to the noises of the creek Gee suggests evil. (In Gee's fiction cats are repeatedly associated with evil - the bloodcat in the $O$ trilogy is an example.) Through changing real history Gee adds to the novel's texture and emphasises its contrasting parts. For example, as previously noted Gee intended the name "Loomis" to suggest something hidden coming into view, thus adding to themes of substance versus surface, and blindness versus seeing. Perhaps the fact that "loom" rhymes with "doom" also makes it part of the image system that Gee seems to see as connected to fate and death (recalling the half world of $O$ ). Thus Gee extends themes of negativity beyond that typified by small-town New Zealand during the Depression.

Differences between Gee's encounters with the swagman and Colin's with the fat man extend the depiction of evil. Where the young Gee (with his mother) hurriedly withdrew from the swagman's presence, Colin stays and steals his chocolate. Whilst emblematic of good, he is also a realistically mixed individual and exhibits a fallibility more strongly represented by Muskie. Indeed, Gee establishes Colin and the fat man as antitheses, each resembling what the other mainly is not, and perhaps drawn to each other for that very reason. Colin is thin, young, and innocent whilst Muskie is fat, middle-aged, and versed in worldly ways. Where Colin represents good, Muskie represents evil. By emphasising that Muskie is not a swagman Gee disassociates him from the everyday world and suggests that he represents Loomis' repressed side and the creek world itself. Indeed, Muskie seems to emerge from a world that is underground, fecal, and black: "[Muskie"s] eyes were angry. They were small and deep and blacker 
than sheep pellets. Herbert Muskie was like something that had rushed into the daylight from the back of a cave" (p. 14).

Whilst representing evil, Muskie, as previously noted, is mixed. By giving him particular physical traits and habits Gee suggests his divided psychological state. For example, Muskie's obsession with cleanliness counterpoints his moral grubbiness and underground activities, and may be an expression of guilt. His greed for food reflects his desire to consume others sexually and psychologically, so that his obesity seems to be what Gee described as "a fatness of the soul" - a physiological manifestation of his appropriation of others' lives, bodies, and minds. ${ }^{57}$ At the same time Muskie's greed seems to equate to a desire to fill an inner hollowness. He thus recalls Paul Prior, and also Raymond Sole and Duggie Plumb (described by Nelson Wattie as "hollow men, resounding with the lives of others" ${ }^{\prime 58}$ ). The scar (lacking in the real swagman) when visible on Muskie's cheek, suggests the surfacing of his inner corruption, potent sexuality, and manipulative will.

Gee's alteration of history emphasises oppositional patterns. Negatives are set against positives, the physical parallels the psychological, and the way is open for an exploration of the human condition, and a possible resolution. Gee's awareness of the book's antitheses and psychic dimension is apparent in his description of it as "a psychological thriller and a classic battle between good and evil". ${ }^{99}$ Although the novel is set in small-town New Zealand and depicts actual characters and events, it has a timeless, universal dimension that extends far beyond historical reality.

\section{The Imagined Environment}

As we have seen, Gee perceived Henderson as having many dualistic features - the creek and the home, for instance. In the novel the same basic polarities are more sharply juxtaposed to reflect the divided psyche as Gee seems to see it during the Depression. Thus in chapter one the world above the creek is full of movement and light, suggesting hope and life, whilst the lower world of the creek is airless and still, suggesting melancholy and death:

Colin went up the creek instead of into town. He rock-hopped some of the way and climbed along the bank where the pools were deep. The creek was in a gorge and the world of streets and houses, and paddocks and cows, was on another level, where sunshine poured down and breezes flapped clothes on the washing line. The wind never blew down here at all and the air was still. When he heard dogs bark way off in the distance or heard trains whistle on the railway crossing, he sometimes felt there was no way up from the creek. (p. 11) 
Most interesting though are not the polarities themselves, but what happens when they meet. Gee has explained: "The essential thing is a tension between what's familiar and what's unknown, between the safe place I had left and the dangerous place I was going to". ${ }^{60}$ In converting the real creek into the fictional creek Gee gives greater emphasis to the tension of polarities and their inner divisions. Loomis Creek is infested with eels and is dark and melancholic, but it also has birdsong, sun, warmth and romance, as Colin realises in chapter seven: "A blackbird was singing high on the far bank, in a tree fern. The sun moved off the surface of the pool. Shade crept up his legs, and Verna's too, but his body stayed warm in the sun” (p. 115). Gee's predominantly secure domestic world in the novel is also divided. The dirt and worms in the Potters' garden (p. 41) are reminiscent of the creek's mud and eels, and Muskie's corruption and worm-like scar.

By pitting the melancholy creek landscape against the home's ordered comfort Gee extends the depiction of a psychological state. But by showing the internal divisions of these opposed worlds he suggests their potential to change. For instance, the polarisation of creek and home is emphasised by their initial placement in separate chapters, with chapters one and two set in the creek world and chapter three set in the Potters' home. But as the novel proceeds the creek world encroaches on the domestic world, and creek and domestic scenes occur in the same chapters. When Muskie boards at Bellevue, something essentially of the creek enters and disrupts the home's normal routines, whilst fear and gloom pervade characters' more rational thoughts. The drowning of Mrs Muskie virtually in her own backyard is an instance of the domination by the depressive creek world of the secure ordered world of domesticity.

The natural world is therefore far from inanimate. If something of the creek enters and disrupts the domestic human world, so too does the landscape change to reflect the human. Indeed, Gee has described Henderson as the "landscape of the human condition" and its features as "first things" that have for him a "continuity and [a] primal quality". ${ }^{61}$ In creating Loomis, Gee develops the landscape as emblematic of the human condition, particularly as it might have been during the Depression. Thus its geology is divided and anthropomorphic, although initially any metaphoric force seems, like the landscape itself, to be latent. It has a throat: "The creek was in a gorge" (p. 11). And it has a head and tongue: "Mangrove creeks at the head of the harbour divided the farmland into tongues" (p. 21). But during the novel what has seemed barely animate comes alive. Thus physiological metaphors are replaced with a sense of human vitality mixed with desperation, and the landscape becomes dynamic - it seems to climb and run and fall: "The track climbed out of the bush, crossed a shallow ford, made a right-angle turn, and 
ran along the side of a new hill. [...] Another hillside, on a steeper plane, ran down to the edge of a gorge. Smooth rock walls dropped out of sight" (pp. 137-138).

As previously noted, Gee tends to describe people from his childhood in terms of polarities: his mother was the "thinker", his father was the "doer". But he also sees that people had internal divisions. His mother was "a presiding feminine spirit" who promoted the traditional mores of "good manners and what was owed to women", and yet she demonstrated liberal attitudes in her choice of "a homosexual couple as close friends". And his active, heroic father also told "marvellous stories". ${ }^{2}$ Gee seems acutely aware of internal divisions in himself, including those moments when he stepped outside normal behaviour to bully the fat boy, or when he and his brothers desecrated the nuns' property next door. It is these contradictions that Gee explores in characters that are as subject to change as the environment.

For instance, Maisie is prim and proper, but is seduced by the hawker into selling Laurie's cups and by the fat man into sampling his sweet oranges. Laurie is energetic and aggressive, but fights according to boxing conventions. Verna is tough yet pretty, and her face is pointed yet soft. Colin is frightened and young, yet brave and responsible. As for Muskie - he is obsessively clean, but smears himself with mud; he "rarely [does] anything without thinking about it", yet his impulse is "to roar and charge" (p. 13); and he loves yet murders his mother.

Opposed characters reflect the dualities of the domestic and natural environments. Maisie is an ordering influence as is the Potter home, but her ordering tendency can be repressive. In contrast, Laurie is energetic and associated with the outdoors, but under Muskie's influence his energy develops into lawlessness. The quiet, gentle Colin reflects his nurturing home background, but learns to be assertive. In contrast, the anarchic, violent Muskie reflects the subversive creek world, but finally becomes more subordinate. Characters therefore operate in tangency with each other and their contrasting environments.

By emphasising the tension of dualities, Gee adds weight to the externally dualistic features of historical Henderson. The fictional environment and characters reflect each other, with each marked by hope and melancholy, and liveliness and despair. Thus the scene is set for a battle on several levels: between romance archetypes, between and within minds, and between characters and environment. Gee therefore demonstrates the energy seen by Raymond Sole as part of the narrative process of creating a whole book. 


\section{The Romantic Imagination versus Mental Collapse}

As we have seen, Gee's adult and child protagonists are often concerned with subdivision, the examination of parts, and their reconfiguration as a more fully understood whole. The Fat Man's Depression setting allows Gee to examine the breakdown and division occurring in physical, mental, familial, social, and environmental structures. The Depression, therefore, becomes a metaphor for a mind on the verge of collapse.

Breakdown is most obviously depicted in the Muskies' fall. But even here Gee's concern with antitheses and balance is apparent. Financially unbalanced, Mr Muskie dies; mentally unbalanced, Mrs Muskie continues to live. Part of a dysfunctional family, the Muskie children have been the victims of sibling rivalry and corporal punishment and have left home; pampered and spoilt by a fawning mother, Herbert Muskie has remained at home as long as he could.

Mrs Muskie's physical decrepitude is evident in her state of dress. It echoes her mental state as she carries out a mindless daily routine:

Her clothes smelled of mould and her shoes were cracked and her leather gloves were split across the knuckles (she always wore gloves, and always a merry widow hat twenty years out of date, with its felt turned green and its decorations, except for one bunch of dried flowers, lost). You got whiffs of sweat from her when you were close - not that you got close if you could help it. Her false teeth clacked. She took them out as she walked home from the shops and wrapped them in a tattered hanky $[\ldots]$.

So she came and went, into town at half-past two every weekday (extra mince on Friday to see her through; a quarter hour of shopping; then up on to the station platform for a ten minute rest on one of the seats, with her shopping kit, a cut-down sugar sack with sewn-on handles, sitting beside her; and home again when the Auckland train had come in. (pp. 22-23)

Although broken down Mrs Muskie is divided, and through her mindless routine re-enacts a story she has created as a romantic alternative to life's limitations. As Colin informs Muskie in chapter two, her daily visits to the railway station are made in hope of her son's return. Indeed, in chapter five Mrs Muskie's imagined story seems to come true, as we learn through Mrs Sargent. Taking up Mrs Muskie's story and describing Herbert's return home, Mrs Sargent, another divided character, imbues it with sentiment, perhaps to supply the romance her own life lacks:

Everyone in Loomis knew what had happened later in the day. Some of them had seen it. It was, Mrs Sargent said, the loveliest thing she'd ever seen, it made her cry. It went like this:

Herbert Muskie and Grandpa Potter drove out to Sunnyvale Station - just a little hut it was on the near side of the creek, with Sunnyvale painted over the door - and Herbert Muskie waited there while Grandpa drove the Buick back to Loomis. Mrs Muskie came into town not long after that, keeping to her timetable - grocer, butcher, station - and when the three o'clock train pulled in from Auckland she stood up as she 
always did and watched to see who stepped down from the carriages. When it was Herbert Muskie, grinning, easy, with a cigarette in his mouth and his hat tipped on the back of his head, she let out a shriek. She almost fell over - did a sideways stagger and held herself up against a goods trolley standing there.

Herbert Muskie ground his cigarette out with the toe of his shoe and went up to her and said, 'Here I am, Mum. I've come home,' and he took her in his arms (Mrs Sargent wipes her eye) and kissed her so her hat tipped backwards at the same angle as his. Then he led her down the ramp to his waiting car. (p. 74)

In self-consciously retelling Mrs Sargent's story ("It went like this"), in adding his own asides ("Mrs Sargent wipes her eye"), and in allowing Mrs Sargent's vicarious romanticism to speak for itself, Gee (or, rather, the narrator) invests the episode with an ironic dimension that undercuts romance. Not only does this emphasise Muskie's utter callousness towards his mother, but it also modifies Mrs Muskie's heartrending plight (perhaps with what is appropriate for the child reader in mind).

As Gee has acknowledged, the original source for Mrs Muskie's story is another story set in the Depression. To use Gee's own term, Mrs Muskie's story is a "straight steal" from Frank Sargeson's "An Affair of the Heart". ${ }^{63}$ (Indeed, the name "Sargent" may be an ironic coded acknowledgement of Gee's debt to Sargeson.) In "An Affair of the Heart" old Mrs Crawley, desolate and bent double from years of toil, trudges every night to the local shelter shed to wait for the bus's arrival and then, after its departure, returns home alone. Compensating for an empty existence, she imagines the return of her long absent son whom she has indulged during infancy and who, since leaving, has possibly had a criminal career. ${ }^{64}$ In adopting Sargeson's story, Gee gives Mrs Muskie's narrow life during the Depression a larger significance and more resonant fictional context. In addition, through the parallelism of the two stories we become more aware of the destructive maternal influence on the son. Like the narrator of Sargeson's story, Gee himself seems concerned with inspecting the reality that lies beneath fiction, along with the human dimension that subverts stereotypes. The adoption of the Sargeson story, therefore, gives the characters and episode a resonance that contributes to the novel's weight.

Other characters attempt unsuccessfully to cover their depressive states with a romantic veneer. For instance, during Sunday dinner at Bellevue House the enactment of niceties between Muskie and Bette is extended in songs of the Depression era. ${ }^{65}$ But when Bette sings "Happy Days" (p. 67) a ghastly reality is ironically emphasised. Similarly, when Muskie has Bette sing the sentimental "Old Fashioned Mother", Muskie's unhealthy relationship with his own mother is suggested. Considered alongside Sargeson's “An Affair of the Heart”, which also hints at an unhealthy motherson relationship, the song's words, "More like two old sweethearts than mother and 
son" (p. 112), contain the suggestion of incest. This theme is taken up again in chapter seven as Muskie prepares to shave Verna's head. On the verge of complete breakdown, he whistles "Three Little Words". But the romantic song's actual words ("I love you") highlight Muskie's unhealthy attraction to Verna which is the opposite of love. ${ }^{66}$ Gee therefore sets popular song against an ugly reality and, weaving the two together, creates irony and depth.

Cinema provides the Potters with relief from breakdown. In chapter three they re-enact a Western. The character of Black Jack, an archetypal "baddie" or outlaw, is straight out of the Depression era's cowboy movies in which, in the lawless days of Old Nevada, Jack and his gang fight the sheriff. ${ }^{67}$ Playing Black Jack and his girl, Laurie and Maisie are hero and heroine: "[Laurie] grabbed his wife and slid down her body until he was lying at her feet. 'Give me one last kiss, gal. I'm dying.' 'Laurie, that's enough,' she said, but she couldn't help smiling” (p. 48). As sheriff, Colin reverses reality. He is the one who wins the fight as opposed to Laurie the outlaw who finally dies: "Colin fired first, and Black Jack dropped his gun and clapped his hand to his forehead. Blood ran down his nose and across his cheek. He fell into the dust and flung his arms wide" (p. 48). Ironically this "fiction" becomes fact in Colin's real life, and it is he rather than Laurie who is ultimately the novel's "hero".

Gee similarly integrates movies into the novel's reality. Having frequented the local movie hall, Colin projects features of movies onto others. For example, he first sees Muskie in animalistic terms with a "behind gleaming like an eel's belly", squirting "creek water from his mouth like a draught horse peeing" (p. 11). But he avoids recognition of this horrible sub-human side by reconstructing Muskie as a gangster. Colin (and Gee) seem to draw on the movie Scarface as the source of this romanticised view. Set in Chicago during the era of prohibition, drink-related crime and gang warfare, Scarface has as its hero Tony Carmonte (a version of real Italian-American gangster Al Capone). ${ }^{68}$ Parallels between Carmonte and the fat man are numerous. Both have scarred faces, wear slouch hats and drive Buicks. Both flick their fingers defiantly, whistle hollowly (especially preceding a crime or shoot-up), and are or have been part of the American underworld of organised crime and gang war. Most significantly, the sole meaning of each one's existence comes from role playing, and each switches roles according to different contexts. As such Carmonte and Muskie are amoral, unstable, and frighteningly vacuous "hollow men". When threatened, they swiftly change from tough guy to lost "kid" and die deaths that are ignoble.

Colin's view of Muskie as gangster is derived not only from his recollection of movies, but also from Muskie's view of himself - the gangster role seemingly giving him 
an heroic identity. The two views fuse and reality for both characters becomes distorted. When Muskie says, "Say your prayers, kid" using "the voice he had picked up in America" (p. 14) he plays to Colin as audience who responds as though he is an accomplice. When Muskie dresses, Colin's view of him as gangster is consolidated and we gain a sense of a hollow man acting a part. As gangster and accomplice, Muskie and Colin become inseparable parts of each other:

[Muskie] took his jacket from the ferns and shook it out and put it on. It made him look even bigger. He took a tie from the pocket and knotted it round his neck. Then he put his hat on, careful not to disarrange his hair, and flicked the back brim up with his fingernail and turned the front one down on an angle. Now he looked like a gangster. Maybe he wanted that. (pp. 19-20)

Gee modifies the gangster archetype by drawing on American comedy, particularly the famous duo of Laurel and Hardy - the skinny weakling and fat bully. Indeed, the movie Laurel and Hardy Way Out West (possibly Gee's source) has the comic duo travelling by wagon over a Western landscape, and Hardy tipping into a creek where he sits spouting water in an arc from his mouth. ${ }^{69}$ Parallels to Laurie and Herbie are obvious. Not only are names, physiques, and personalities similar, but in chapter one Muskie sits in a creek spouting water from his mouth.

Gee weaves the comic duo into Colin's thoughts to suggest that through fiction Colin too is trying to keep an unpleasant reality under control. An allusion to Laurel and Hardy occurs in chapter three when Colin uses them as a device for reducing Muskie's presence as gangster to the level of buffoon:

\footnotetext{
When people like Herbert Muskie take up residence in your mind there's nothing you can do to get them out. [... ] The most you can do is shrink them a little, perhaps by remembering things supposed to be funny: a bald head with hair pasted on it, a Laurel and Hardy jacket looking ready to burst. (p. 40)
}

As he exists in the novel, then, Muskie embodies characters' fears, especially Colin's. As a hollow man, his identity is partly dependent upon others and the roles projected onto him, including those projected by the author. Paradoxically shallow and unbalanced, Muskie contributes to the novel's resonance and balance. Moreover, through depicting the influence of movies on characters, Gee weaves movie scenarios into the plot. As Manhire has commented: "Films in fact are influential in the environment of Gee's early fiction. They supply stylized models of 'real life' which provincial and adolescent New Zealand might aspire to, they make a difference to behaviour". ${ }^{0}$ Thus integrated, "fiction" (the movies) and "reality" (characters' actual existence) become inseparable parts of each other. 


\section{The Elemental Landscape}

Gee extends the fluid relationship between Colin and Muskie, and fiction and reality on several levels. Indeed, the flowing together of things seems to portend breakdown and dissolution. In chapter two the elemental threatens to consume Colin: "Colin washed. He tried to brush the dust off his clothes, but the damp had sucked it in and turned it to dirt" (p. 38). Features of the landscape appear to divide and ingest: "Mangrove creeks at the head of the harbour divided the farmland into tongues. On the inland side were hills and deep valleys and freshwater creeks like the one where Colin Potter met Herbert Muskie. A few dirt and gravel roads ran into the ranges and down the other side to the black sand beaches of the west coast" (p. 21).

With the near personification of the landscape, boundaries between it and social factors blur. In chapter one, for example, the land's greed and urge to devour are apparent when Loomis creek, situated in a gorge, is effectively swallowed by the earth's throat: "The creek was in a gorge [...]. The wind never blew down here at all and the air was still”' (p. 11). Low-lying and stagnant, the state of the creek seems to correspond to the social depression caused by a rotten economic system that has leeched people of dignity and hope, and to the physical and mental breakdown that results. Conversely, in chapter eight, the landscape's urge towards freedom and life is reflected in "the river [that] ran below, deep in the gorge, white and green" (p. 139), suggesting movement, vitality and hope. The elemental landscape is not, therefore, just inert or crudely materialistic, but has a palpability to which one responds. It would be going too far to say that it represents a spiritual state, but its realism shades into an almost melancholy symbolism that subtly hints at the dilemma of its world and its people.

The narrator's imagination also seems fluid. Like the creek it cuts across boundaries to depict the full range of human experience, but it also tends to venture into areas unsuitable for the child reader. Indeed, when the story line threatens to run away with itself, the narrator steps into the book to bring it back under control. Thus in chapter one the narrator hints at the horrible events that have swept up Colin. He notes: "It took longer for other things to heal", but then reminds us that "we must not get ahead of our story" (pp. 9-10).

Gee's world view seems to be of a coherent, immensely patterned, fluid reality within which images coalesce and re-form. In creating a web of interrelationships Gee apparently wants to emphasise the significance of human interaction, but at the same time he shows breakdown to a level near to meaninglessness. Gee achieves a more 
resonant novel by paralleling the physiological, mental, social and elemental, thus commenting on the individual and collective condition during the Depression.

\section{Inter-relationships}

Characters therefore occupy unstable positions as they transgress moral and social boundaries, and appropriate others' possessions or positions. Laurie and Maisie, and Herbie and Bette demonstrate attractions towards each other, whilst Muskie displays a sexual attraction to Verna that threatens her relationship with Colin. Most important, though, are the interrelationships of Colin, Laurie, Muskie, and the narrator, and it is to these that we now turn.

Initially romanticizing Laurie, Colin believes him to be the tough guy movie hero, and aspires to a similar heroic status. But Muskie's evil influence causes the reduction of Laurie in Colin's mind. Witnessing Laurie's loss to Muskie during the arm wrestling match, Colin is forced to see Laurie as weak - a view suggesting more than just the physical: "His father was defeated. The fat man had beaten him, more than just with arm wrestling. He had made him smaller somehow" (p. 100).

The process of reversal is one in which characters effectively absorb or consume each other. The arm wrestling match between Laurie and Muskie seems to be a pact an ironic marriage into crime - and Colin realises how Laurie may comprise nourishment for Muskie's aggrandisement: “The fat man took his jacket off. Yellow braces held his trousers up. His torso was rounded like a melon. Laurie was a beanpole beside him. His hands were bigger though and his arms more muscular. [...] When they clasped hands the brown one almost swallowed up the white" (p. 95). Imagery of ingestion also emphasises Colin's growing recognition of Laurie's moral weakness, when he sees Muskie’s cleverness as “sucking Laurie in” (p. 124).

Gee depicts Colin's final realisation of the interwoveness of Laurie and Muskie literally and metaphorically as ingestion. In chapter eight Muskie's recounting of the spit sandwich episode from his childhood allows Colin to understand Laurie's past nastiness to Muskie (who refers to Laurie by his nickname Pottsie). Colin therefore realises why Muskie has forced him to eat his spit in chapter one:

Pottsie would say, "We've got a sandwich for you, Herbie." One of them would hold it out, and then they'd pull it back and say, "We'll just make it taste better, eh?" They'd take the top off, see, like this. [...] Then they'd all spit on it, each one. [...] Then they'd put it back together again and make me eat it. Spit sandwich was its name. I ate one of those every day. (pp. 133-134) 
Physically and mentally, then, Muskie has consumed Laurie. In eating Laurie's spit, Muskie has literally taken Laurie's bodily fluid into him. Symbolically, therefore, Laurie has become part of Muskie who, consumed or obsessed by him, exactly replicates his behaviour. Where Laurie was a gang member and bullied Muskie, Muskie is now a gang member who bullies Laurie and Laurie's child who sees his father shrinking "to something small and dark inside him" (p. 134).

As Laurie shrinks in Colin's mind, Colin grows. From being a cowardly boy who fears the Rice gang and fat man, Colin becomes the hero he initially believed his father to be. But Colin's heroism is psychologically complex. Through his encounters with Muskie he enters an underworld and encounters a reality larger than romance. In chapter four, after learning of Laurie's past attempt at drowning Muskie, Colin makes an imaginative double shift. He puts himself in Muskie's place and Muskie in the place of Laurie: "Colin felt as if he had been pulled below the surface in one of the deep pools of the creek. He felt the fat man hanging on his legs" (p. 57). The crossover of identities anticipates Colin's greater understanding of Laurie (and Muskie) and his responsibility for them. Thus, when Colin takes his father's hand at the end of chapter six, it is in a more responsible sense rather than as a fearful child: "Colin took [Laurie's] hand as they walked along, and Laurie, who would normally have thought it was sissy, held it and did not seem to mind" (p. 101).

Although polarised, Colin and Muskie start to shade into each other from the moment they first meet. In chapter one Muskie appears to be a satanic, obese infant indulging in water and mud play in the creek, whilst Colin imagines handing him in to Constable Dreaver, and plays the part of tough guy hero. But when the fat man forces Colin to eat his chocolate (repeatedly depicted in terms of dirt, it can be equated - in Freudian terms - to fecal matter), the roles are reversed. That the fat man also forcefeeds Colin his spit has similar nasty implications.

A parallel incident occurs in Sole Survivor. Upon visiting the home of Sutton and Bluey Considine (who are respectively homosexual and heterosexual) Raymond Sole observes Sutton dropping "a gob of spit" into a cup of tea which he then serves to Bluey. Raymond believes the action reveals "the richness of [Sutton's] life". He realises “This was [Sutton's] way of having Bluey and of forcing Bluey to have him" and that it is "an act of communion" (p. 89). As such the act fuses the spiritual, the physiological, and the sexual, and is an expression of love. The act of force-feeding Colin spit is the very opposite and an expression of hatred analogous to rape with Colin, literally the recipient of the fat man's juices, symbolically impregnated with the seed of evil. The spit sandwich episode from Muskie's childhood anticipates and parallels this act and resembles a gang rape by Laurie and his friends. 
As Muskie in eating Laurie's saliva has become possessed by Laurie, so does Colin in eating Muskie's saliva seem possessed by Muskie. Described by Muskie as "snivelling" (p. 17) and "blubbing" (p. 18), Colin occupies an infantile position recalling Muskie in the creek: "Sobs rose in his throat $[\ldots]$. Tears rolled down his cheeks all the same. They wet the chocolate round his mouth" (pp. 17-18). Colin seems foetal - like a baby attached to Muskie by an imagined umbilical cord: "Colin knew that if he tried to sneak away there'd be a tug on the invisible rope that linked them, and the man would turn and pull him in" (p. 26). Conversely the fat man appears to Colin to be larger than life: "He took his jacket from the ferns and shook it out and put it on. It made him look even bigger" (p. 19).

The narrator appears to participate in this process of absorption. Although writing mainly from a third person stance, he is far from detached and very much a character in the story - one who struggles to control his material. His intimate knowledge of action, inclusion of detail listed in an almost ad hoc manner, and asides in commas and dashes, resemble memory's random musings. As is apparent in chapter one his obvious awareness of the future, use of personal names ("Grandma"), the first person plural ("we [ ...] our"), and indeterminate second person pronoun ("you") suggest his involvement. This free indirect discourse and accessing of Colin's thoughts suggest, moreover, an intimate identification with Colin. Thus the narrator both controls and is absorbed in the characters and story:

\begin{abstract}
As well as being hungry [Colin] was greedy, which got him into trouble so bad that he could have ended up in a hole down by the creek. He did end up with a broken arm, but that healed quickly. It took longer for other things to heal - but we must not get ahead of our story, which begins on the day his mother gave him bread and dripping and sent him outside. He ate it, although it was the sort of thing you fed the fowls. There was a bit of meat dripping, from Grandma's roast of beef which they had shared last Sunday. (pp. 9-10)
\end{abstract}

In chapter three Muskie's satanic appropriation of Colin's soul is explicit and he seems to lodge in Colin's mind just as he lodges in Bellevue. Perhaps, too, the fat man is lodged in the memory of the narrator who may be an adult Colin. For here the narrator's empathy with Colin is especially evident. Indeed, with repeated allusions to the second person and a full shift into the present tense, the narrator, Colin, and Muskie seem to fuse:

When people like Herbert Muskie take up residence in your mind there's nothing you can do to get them out. [...] They're always there, they'll always come out, even when you're sure they've left the district. [...] You wake in the night and the house is dark and the floors are creaking. Then you remember a razor perhaps, or a scar like a worm that wriggles in a cheek, or the terrible quickness he can move with - a fat man moving with a dancer's speed. And the strength in his white hands. The darkness in his eye. 'Kid' whispers in your ears when you wake at night. It has become a terrible name. 'The fat man' is a terrible name. (p. 40) 
However, Muskie falls from tough guy status to an infantile state that recalls the weakling role he has forced on Colin. In chapter eight, lifting his drowned mother from the creek, he cries like a baby: "He sat and held [his mother] in his arms, with her grey nightie draped in folds and her white feet sliding on the mud. [ . . ] He hugged her against his chest and dripped on her and let out cries like the mooing of a cow" (pp. 105-106). As Colin realises, the child-like Muskie holds his mother "on his chest, like a doll" (p. 107), whilst Verna notes that he "cries in [her pillow and sucks] his thumb" (p. 112).

Muskie's fall to infancy is accompanied by Colin's rise to maturity. Through being the weakling, Colin acquires a more realistic view of Muskie and can identify with him as a victim. Thus Colin moves from a simplistic perception of Muskie (as movie stereotype) towards a more ambiguous picture of him as a complex human being. $\mathrm{He}$ recognises Muskie is divided - that he loved yet killed his mother, that his bellow upon discovering her drowned is one of "rage or grief" (p. 105), that he is hollow and unstable and, "like switching stations on the radio", is able to "change into anything" (p. $117){ }^{71}$

Muskie's regression to an infantile state and beyond that to annihilation is completed in chapter eight. On the run from police, he attempts to fill his physical and mental emptiness by eating and drinking: "'Hand me some of that chocolate sponge'. [ . . ] Herbert Muskie ate. 'You, kid. There's a bottle of whisky there, beside me case.' Colin passed it over and Muskie swigged a mouthful. [ . . . Herbert Muskie was eating ham sandwiches, taking them from the bag in threes” (pp. 131, 133).

Initially embodying his masculinity, the Buick is now "like a farm tractor" (p. 135), and little of Muskie's ability to think clearly and cunningly remains: "Colin saw that he had lost his judgement, lost his way" (p. 135). Moreover, Muskie reverts to the time when he was bullied at Loomis School: "Herbert Muskie had turned into the fat boy again, running from the playground gang at Loomis School” (p. 138). Muskie's tears and reference to Colin as "Pottsie" (Laurie's nickname) suggest he now believes Colin to be Laurie: "Tears leaked from the fat man's eyes and dripped on the platform. He was changing back and forth. 'Pottsie, you're helpin' me now. Aren't you, Pottsie?”' ( $p$ 139). As he enters the flying fox's cage Muskie's progression to infancy is complete: "[He] squatted like a child in a box too small for it, holding the couplings with two hands" (p. 139). Ironically he is the reverse of the tough guy role he previously enacted.

Instead of flight or transcendence, therefore, Muskie plummets from the flying fox to death. The shift from "Herbert Muskie" to "the fat man" (p. 140) emphasises his loss of identity and reversion to an archetypal role. Falling into the river, he joins the 
element from which he seems originally to have come, and completes the circle of his existence. The contents of his suitcase comment sadly on his soul's plight. Like descending birds, his garments are the very antithesis of the traditional representation of the soul as a bird in flight, spiralling up towards heaven: "Herbert Muskie fell. The fat man fell. He turned over once and struck the rocks at the side of the river and slid down them into the white water and was gone. His suitcase fell too. It opened out its lid and his shirts and underpants circled down like birds" (p. 140).

Colin's movement towards maturity exactly reverses Muskie's regression to childhood and the elemental. Ironically, as Colin releases Muskie from the stereotyped roles of romance movies, he moves closer to him as an individual who has an identity and specific name: "A strange thing - Colin called him Herbert Muskie from this time, as though they had moved closer and the fat man had a name" (p. 119). Thus, although moving in reverse to Muskie, Colin makes the imaginative leap that brings him closer to Muskie and causes him to feel compassion. Thrust by Muskie into Laurie's role, Colin no longer emulates Laurie or tries to be a hero. Instead he becomes a different sort of accomplice to Muskie, whose human frailty and breathy emptiness he now recognises, and with whom he moves in harmony: "Colin ran. He ran with the fat man along the side of the gorge, listening to him pant and wheeze, seeing him stumble" (p. 139).

In cutting the flying fox's rope and briefly giving Muskie freedom and flight, Colin perhaps intentionally reverses his father's earlier bullying acts. In effect, Colin also cuts the umbilical cord binding him to Muskie and births him out of his system. At the same time he rids himself of the evil by which he has been possessed: "Colin saw there was no way of untying the knot. The fat man's weight had pulled it too tight. He took the razor from his pocket and unfolded it. [ . . ] Colin cut the rope" (p. 140). But Gee does not allow us to view Colin's brave deeds simplistically as heroic, and continues to ensure the reader's detachment from sensational events. Indeed, chapter eight opens with the omniscient narrator reminding us that it is all just a story with a foregone conclusion: "One more chapter will finish our story. A night and a day and it was over - Colin, Verna, Laurie and the rest were free of the fat man. He nearly dragged them under but not quite" (p. 119).

As the chapter progresses, the landscape, tone, and action contribute to the distancing cinematic effect. Where Henderson and the Waitakeres (situated in western areas of Auckland) represented "the Wild West" of popular belief and Colin's cowboy fantasies, Ngatea and the Hauraki Plains seem to resemble Buck Duane's "badlands" or a movie set of the same. ${ }^{72}$ Certainly the "hillsides, high above rivers that turned from green to white" (p. 133), the "bare hill [with its] track worn by horses and sheep [...], 
yellow clay [that breaks] under the wheels [... ], clods [bouncing] down into the gully" (p. 135) and "shallow ford" (p. 137) recall the American Western's desert. But the narrator avoids sentimentalising the scene, and instead emphasises characters' departure from the west (of Loomis and West Auckland) and actual journey east (towards the North Island's East Coast). Potentially romantic overtones are also pre-empted by the farcical nature of events - the baddie and goodie are a fat boy and a skinny boy, and the Buick "bucking and heaving in the ruts" (p. 137) is no bucking bronco.

Indeed, the landscape is the reverse of that depicted in chapter one. Where the creek world was situated in a gorge and presented as an underworld - dark, airless, and static - the rural landscape "across the top of the Hauraki Plains" (p. 132) is presented as a higher world - predominantly hilly, light, windy, and in motion. Rather than heaven, this higher world is a surreal, desolate scene in which the individual is very small. Furthermore, in this almost symbolic landscape, action occurs simply as an expression of the elemental. Thus in running, climbing, disintegrating, and falling, characters echo the movement of the wind, hillside, and river below. Most significantly their desperate hunger for life corresponds to the hunger of the land itself:

Scrubby hills, eroded with slips, fell away to the distant coast. A cold wind was blowing and clouds were piling up on the higher hills behind them. (p. 133)

The Buick [... ] crossed and recrossed the creek, up to its running board in the water, then went up a bare hill, on a track worn by horses and sheep. Yellow clay broke under the wheels and clods bounced down into the gully. Far off, the sea glittered and white beaches showed in bites of land. (p. 135)

They started off again, bucking and heaving in the ruts. The track climbed out of the bush, crossed a shallow ford, made a right-angle turn, and ran along the side of a new hill.

[...] They ran on the hillside, heading towards a spur. Verna and Colin tripped and fell, but Herbert Muskie heaved them up and pushed them on.

[... They ran again, and reached the spur. Another hillside, on a steeper plane, ran down to the edge of a gorge. Smooth rock walls dropped out of sight. (pp. 137138)

The river ran below, deep in the gorge, white and green. (p. 139)

Colin's heroic freeing of the fat man is also undercut as it sends Muskie to his death. Whilst the killing of the baddie by the goodie typifies the endings of cowboy movies, Muskie's killing by Colin is no simplistically depicted feat. For prior to cutting the rope of the flying fox, Colin is shown to be fully aware of the possibility of death. He also recognises the effects of a vast elemental hunger, and perhaps the possibility that absorption back into the elemental may be a merciful release: "Colin saw how eaten with rot the planks of the cage were. It strained to get away down the wire. The river 
ran below, deep in the gorge, white and green" (p. 139). It is an insight Colin seems to apply to Muskie who, consumed by the corrupting effects of his life, also strains for release: '“Please, Pottsie,' Herbert Muskie wept. [... ] 'Pottsie, cut it, eh. Go on, do it, kid"' (p. 140). Colin's release of Muskie is thus psychologically complex. It is a fully conscious killing, but as Anna Nieuwenhuizen has argued, it is also "an extraordinary act of compassion and deep understanding". ${ }^{73}$

The narrator has the final word in the story. The epilogue's flat, detached tone in chapter nine reminds us that in the everyday world heroes and heroines do not marry and live happily ever after. But the story ends on a mysterious note with the narrator claiming, "Verna is the only one who knows why Colin ran with the fat man in the end, and cut the rope" (p. 142). With Colin's reasons for cutting the rope so shrouded in mystery, it seems that the narrator (and Gee) are casting a veil over what effectively is Colin's killing of Muskie. His motive, therefore, remains unrevealed. Whilst a murder may be fine in a Wild West movie, it is not appropriate in a realistic novel for children. The ambiguous ending certainly accommodates something that comes from a more clearly fictional world or exotic past. But that the fat man's story has been told - that the novel has been written - suggests that, although Colin may have released the fat man, he remains an enigmatic presence in the mind of the narrator (and author) forever.

As a lasting presence within the mind, Muskie could be described as embodying an emptiness existing in everyone that paradoxically stimulates the imaginative or fictive process, hence the various roles that characters (and author) have projected onto him. That Gee felt compelled to recall the swagger in Henderson Creek and fictionalise him suggests the novel may be a way of accommodating a presence that must be re-visited time and again, but yet remains never completely understood. Ironically, therefore, it seems likely that the fat man, and before him the swagger in Henderson Creek, may possess the author.

\section{Conclusion}

The cycles of absorption and exchange, and the fusion of historical reality and fiction, and characters with each other, the landscape, and the author/narrator results in a whole novel that takes its largest meaning from interrelated, constantly changing parts. Meaning for Gee is thus mobile and dependent on context. The movement of Gee's childhood memories into fiction and the mind of the narrator (who remembers Colin's childhood - a reflection of Gee's) epitomises the fluidity, coherence, and circularity of Gee's world view. Ironically this reflexive, coherent reality is both stimulated and undercut by the presence of emptiness. Embodying the void, the fat man is finally a reflection of all who have made him what he is. 


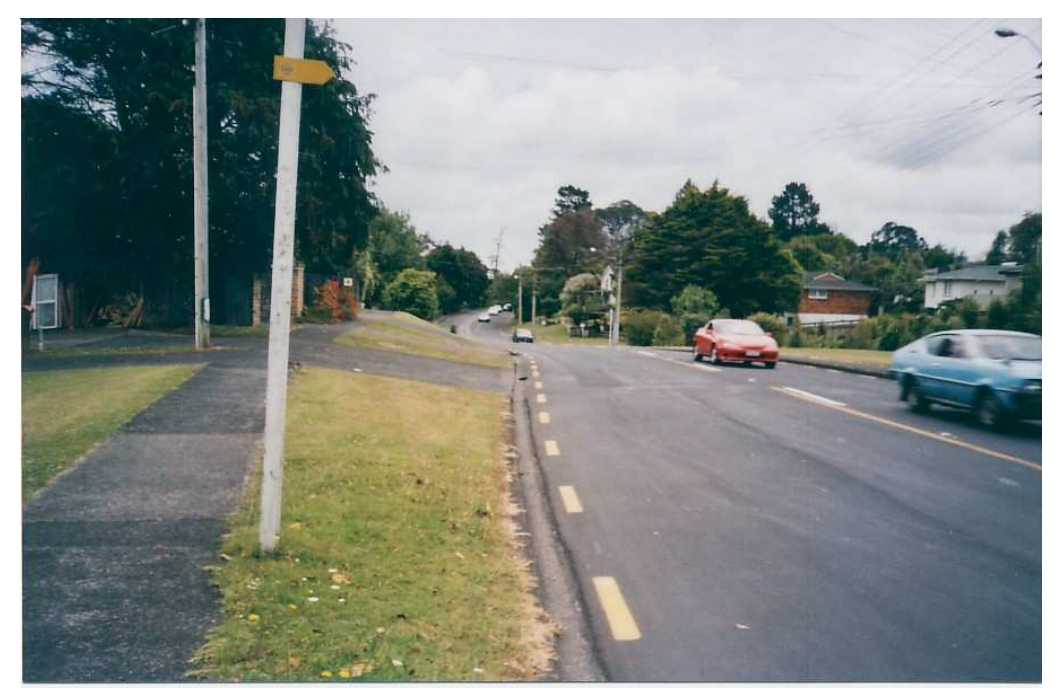

FIGURE 1

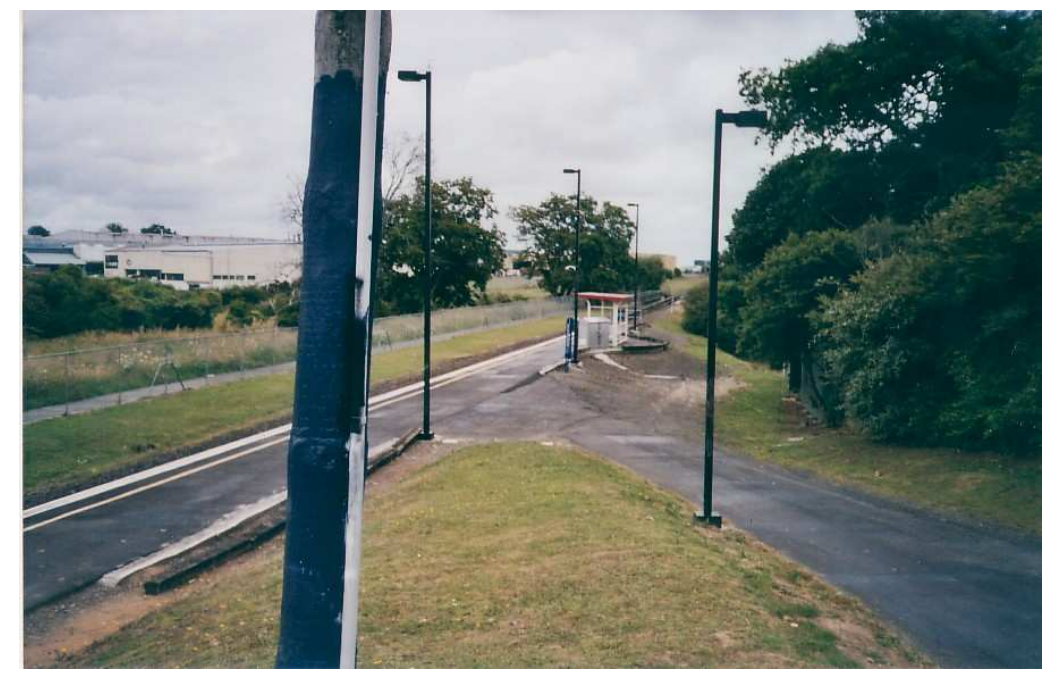

FIGURE 3

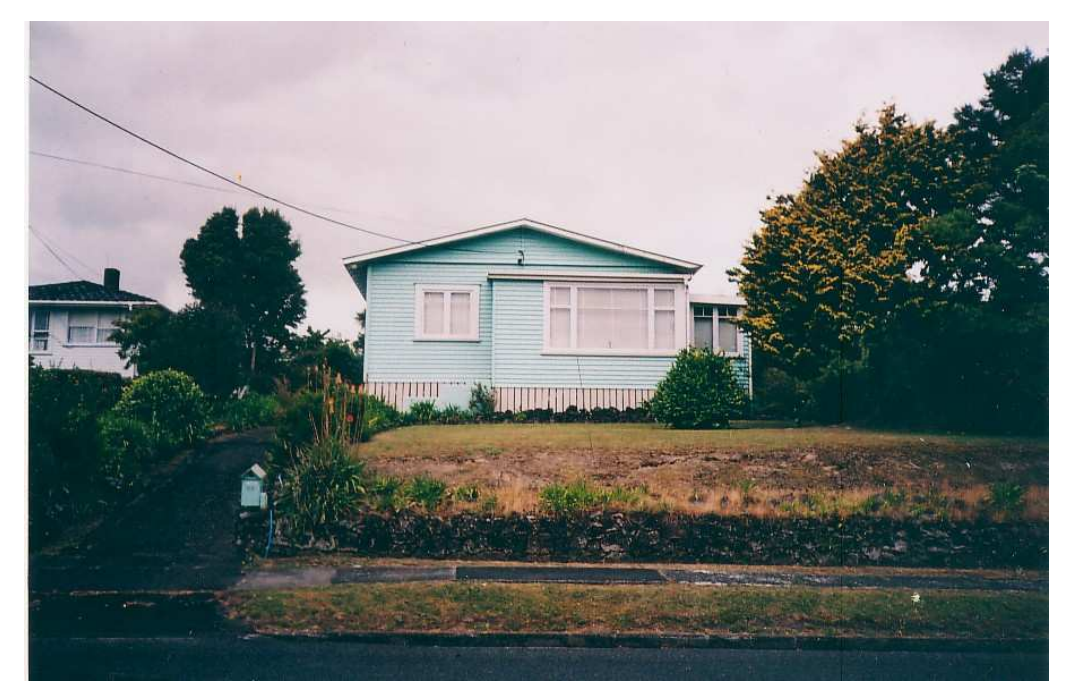

年

FIGURE 2

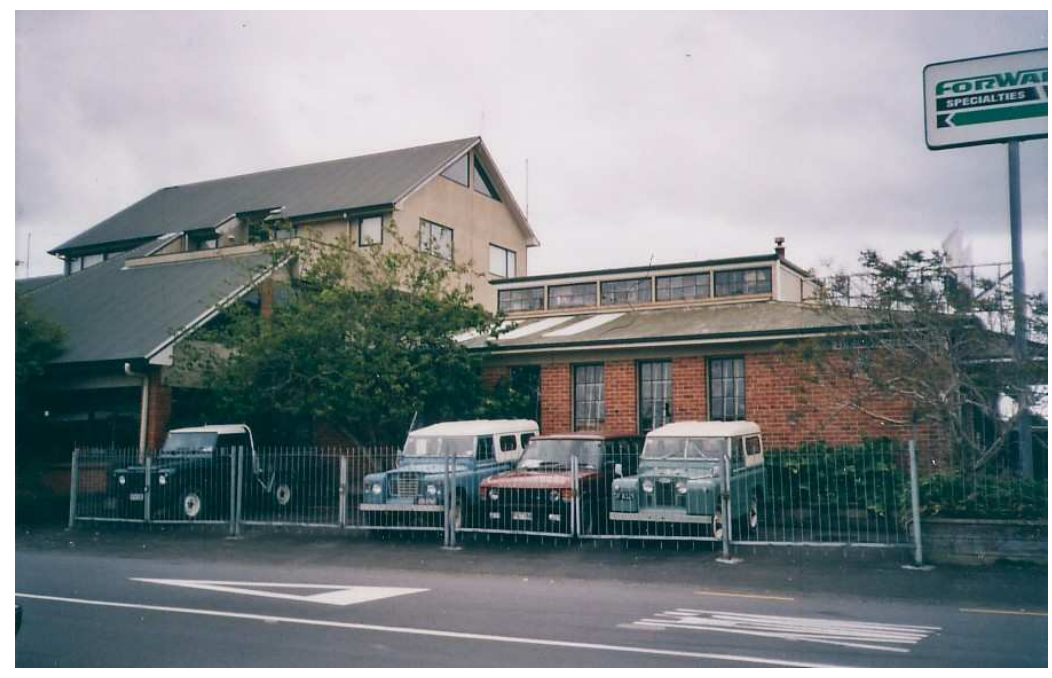

FIGURE 4 

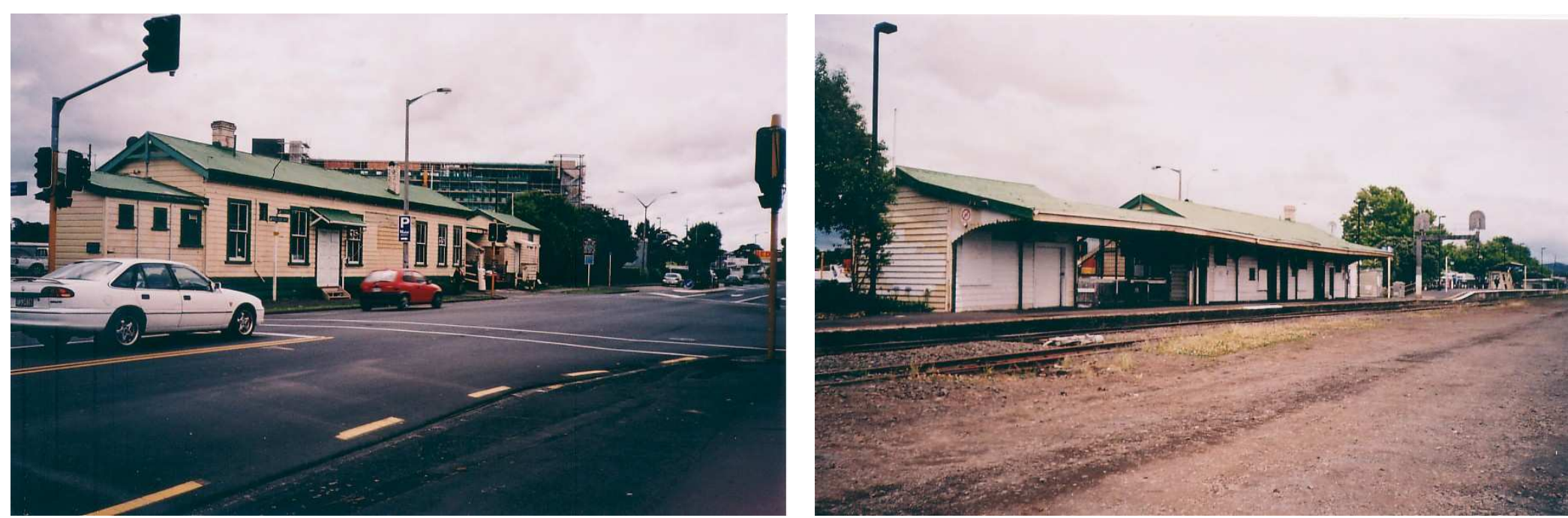

FIGURE 5

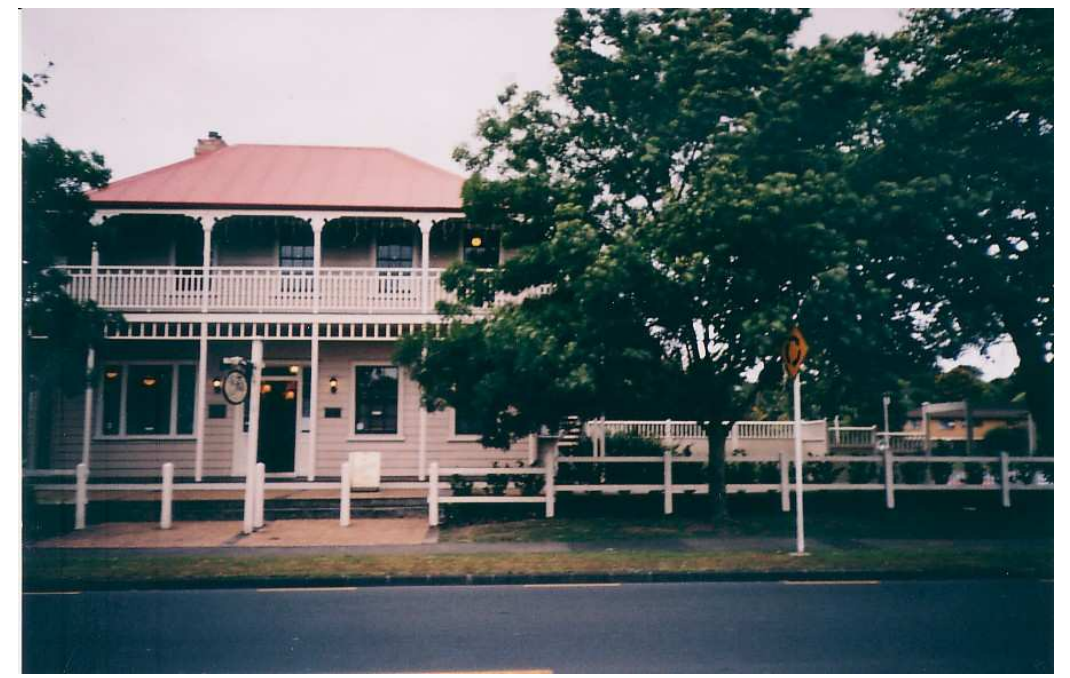

FIGURE 7
FIGURE 6

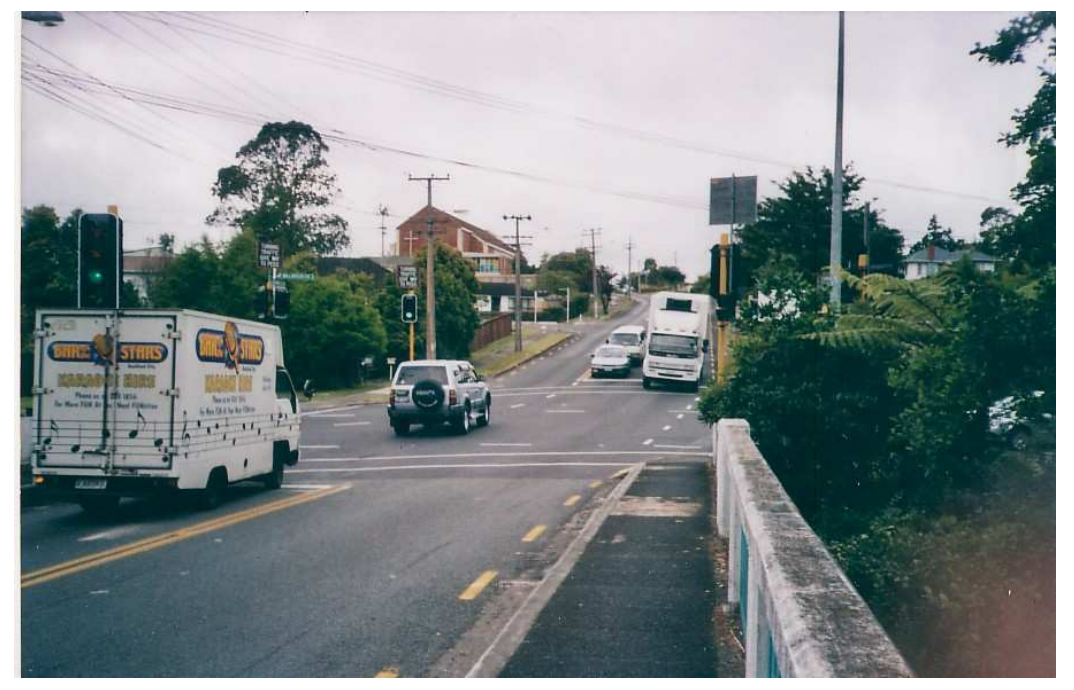

FIGURE 8 

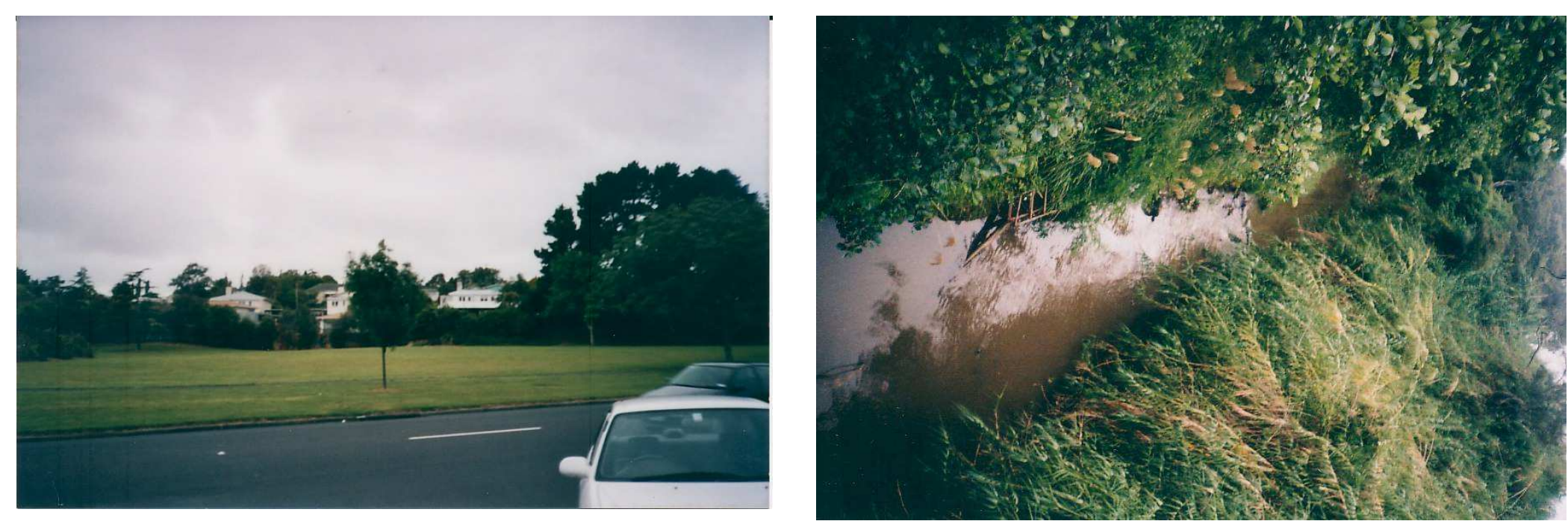

Z

FIGURE 9

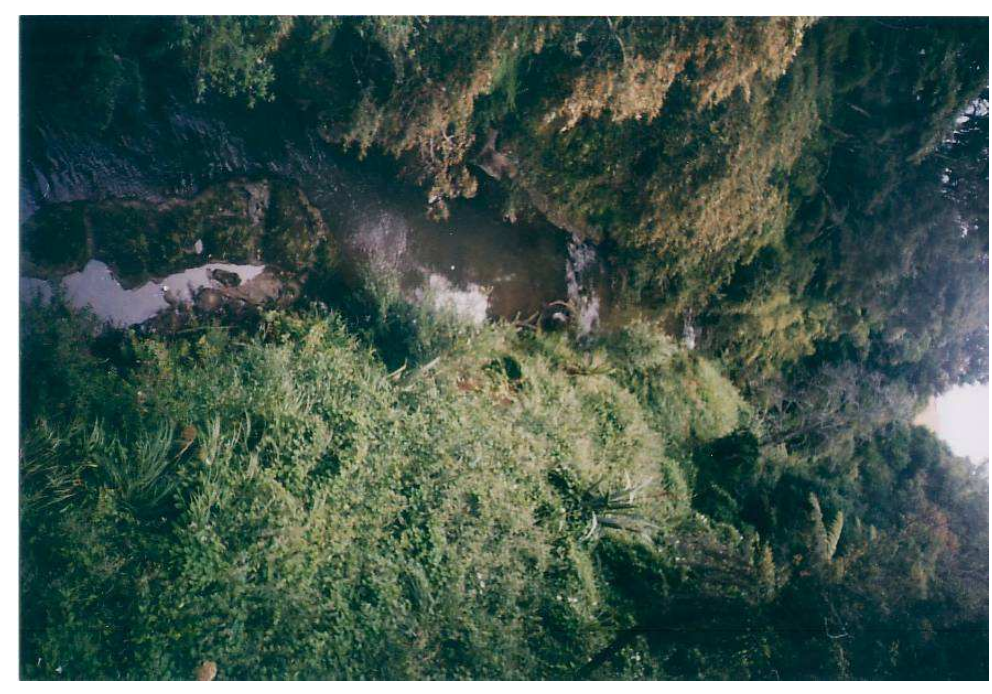

FIGURE 11

\section{FIGURE 10}

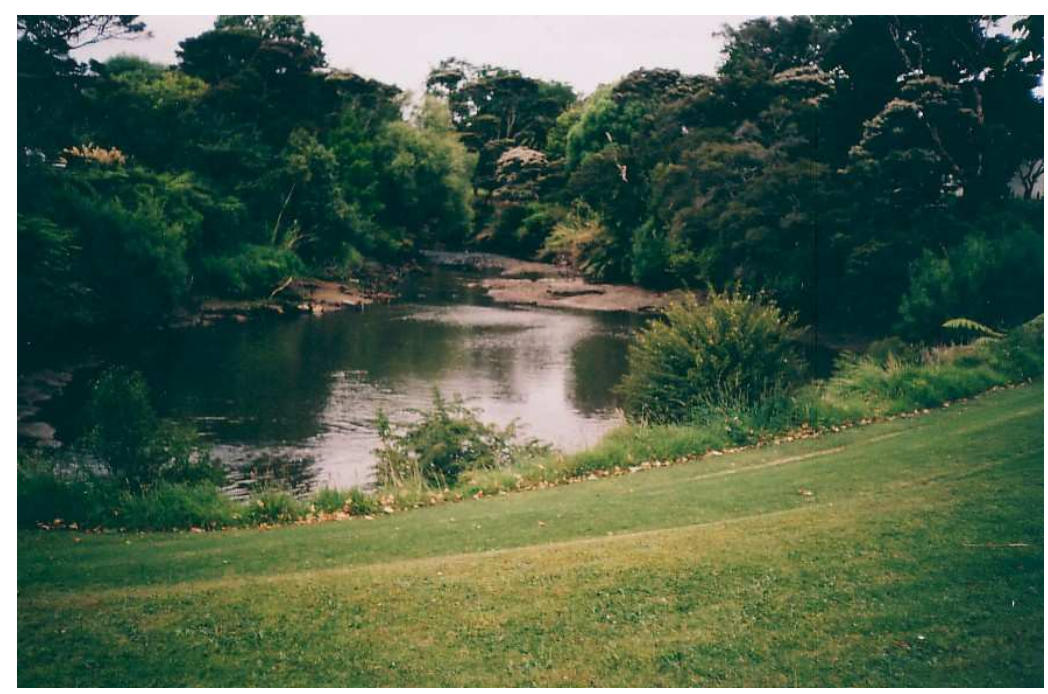

FIGURE 12 


\section{CHAPTER 6}

\section{Orchard Street}

\section{Introduction}

Orchard Street is set in 1951 during the conflict between the Waterside Workers' Union and the National government. Having depicted in the first three historical novels the sociable Hedges, Jackson Coop, and Colin Potter, and their antitheses - the aggressive Edgar Marwick, Rex Pascoe and Herbert Muskie - Gee further explores sociability and aggression in individuals. He seems to see these characteristics as reflecting a society that is politically divided between socialism and fascism. Now, however, opposed characters are not so sharply set against each other. Indeed, the protagonist, Ossie Dye, and the "villain", Ian Pike (nicknamed "Bike"), are almost friends, and sociable and aggressive qualities are more evenly shared. ${ }^{1}$

\section{From Newington Road to Orchard Street}

As we have seen, for Gee "the real" is an important part of the whole, and in this novel he turns, as in The Champion and The Fat Man, to his childhood hometown of Henderson. Moving from the earlier more rural Henderson of the previous two novels, Gee focuses in Orchard Street on an increasing urbanisation. The fictional Orchard Street is based on Newington Road where the Gee family lived. As a contemporary street map of Henderson shows, Newington Road runs between the Great North Road in the north, and View Road in the south, being the first turn left off the gently sloping View Road.

In "Beginnings" (an autobiographical article written twenty years before the publication of Orchard Street) and "Creeks and Kitchens" (a lecture given in 2002) Gee has recalled his neighbours in Newington Road. ${ }^{2}$ He identified the house on the corner (presumably on the lower western side at number 61A) as the residence of a friend Murray whose father drank poison in the bathroom (see figure 13). Then came a paddock (today occupied by contemporary villas). According to a local resident still living in Henderson, the next house at number 55 belonged to the Harts (who donated land for the nearby Hart Domain). ${ }^{3}$ Gee has remembered Mrs Hart, who wore a lace cap and sat on the porch (see figure 14). Further along, several cottages were built for railway workers on land once owned by the Railways. As recalled by the resident, number 51 - the Flynns' house - was one of these, and Mr Flynn was a railway engine 
driver, although later the house was bought by the Kays (see figure 15 which also shows the Waitakere Ranges looming in the west). Gee has noted that Mrs Kay believed in Radiant Living (a new age religion which espoused healthy living) and fed her son nuts and raisins, and that his was consequently the worst birthday party he ever attended. According to a local resident, the Kays lived next door to the Scotts at number 49 and Mr Scott was a chemist (see figure 16). Gee has recalled that Mr Scott kept budgies in a cage and once made a huge kite that he carried through the Gees' section to farmland at the back, but that when he tried to fly it, it broke and he cried. The local resident has described the Greenoughs who came to Henderson in 1938 and lived in another railway cottage at number 47 (see figure 17). Stan Greenough worked for the railways, first as a shunter and then, after an accident, as a signalman. Gee has recollected that $\mathrm{Mr}$ Greenough later became a florist who could make flowers by wiring the centre of one to another (which his mother said was unnatural) and son Gordon, who had a dog named Patch that could skin hedgehogs alive.

Halfway along Newington Road a slight dip marks an area which was once farmland that cut across the road, developed as it was by the Railways from its north and south ends. During Gee's childhood the street would have seemed to be a cul de sac (or what was commonly termed a dead or blind end). According to a second local resident, the farm was originally owned by the Donohies, who were probably Northern Irish - Mrs Donohie seemed to be bitter about Catholics. ${ }^{4}$ Evidently it was not until 1947 that the road went right through, so that its two separate ends were joined. In 1960 its sections were numbered, starting from the northern end.

Turning from the blind end back down the road, on its higher eastern side, one passes number 48 in which lived a Mr Booker in a house imported from Holland. Next, at number 50, Mr Verijt resided on land formerly owned by the Gees, first in a shed and then in a house built around the shed. Then comes the house at number 52 that belonged to the Gees, today painted blue (see figure 18). ${ }^{5}$

As noted by Gee in "Beginnings", his family was Labour and Pacifist. Gee's mother is still recalled as "not very modern", and as having long hair plaited around her head, and clothes that were "way out" and long. She did not mix socially. Gee's father, however, was tall, fine looking and thought friendly. ${ }^{6}$ Originally from New Plymouth, a builder and a boxer, he helped construct Henderson's Bank of New Zealand on the Great North Road, and also some of its state houses and shops, and Auckland's Civic theatre. It seems that he had part ownership of a racehorse and placed bets with Norcross (a bookie), but that someone "potted" and when police raided his home about 
the time of the watersiders' lockout Norcross was caught. ${ }^{7}$ Gee acknowledges in "Creeks and Kitchens" that his father's two best friends were the local bookmakers.

Over the macrocarpa and pine hedge at the back of the Gees' section was farmland, and beyond that the Catholic School. As described by Gee in "Beginnings" and "Creeks and Kitchens", there, from the top of a bank, he and his brothers spied on the nuns as they walked singly or in twos. With their beads and crosses they seemed sinister, dangerous, and hateful. There were three Gee boys - Ainsley, Maurice and Gareth (nicknamed Junior, Mossie and Gussie). ${ }^{8}$ Gee's mother supplied the young Gee with books to read. Indeed, Gee has recorded that he befriended the Harts over the road so that he could borrow books after playing Mr Hart at draughts. First he read Zane Grey's novels, and later Dickens. Gee, moreover, has recalled Mr Hart as "my Dickens man who died from grief shortly after his little dog was run over by a car".? Attending Henderson Primary School, then Avondale College, Gee became first dux of Avondale in 1945. Apparently Gareth worked in the bank and, armed with a gun, slept over for security, and once burnt down the Gees' toilet, so that on VC Day Mr Gee had to build a new one. (The remains of this are still visible behind a scrubby hedge halfway up the section, see figure 19.) In "Creeks and Kitchens" Gee himself has recollected his brother as a bank Junior, aged sixteen, staying overnight in the bank, his loaded revolver in the bedside drawer, and target practice down by the creek. He has also noted that a bank Junior shot and killed his friend, mistakenly taking him for a burglar when he climbed in the window.

At number 54 the Pinkneys once lived, separated from the Gees next door by a privet hedge (see figure 20). Mr Pinkney was in the airforce during World War I, then married the adopted daughter of Mr Hart, and made tents during World War II. Mr and Mrs Pinkney were the only National Party members in the street and Mrs Pinkney wore a blue dress on election day. In later years the Pinkneys had a musical circle - Mr Pinkney played the violin whilst Mrs Pinkney played the piano. ${ }^{10}$ Apparently Mrs Pinkney had a beautiful garden and only grew flowers that matched her house, whilst Mr Pinkney ("a dear old soul”) went on trips to England after she died. ${ }^{11}$

\section{The Novel}

Much of Gee's personal history appears in Orchard Street. Indeed, the location and layout of Newington Road exactly matches the fictional street's location and layout. Just as the young Gee would have walked up View Road to turn into Newington Road where the Gees live, Ossie walks “up the hill” (pp. 58, 82) before turning into Orchard 
Street where the Dyes live. Like Newington Road, Orchard Street has an upper side: In chapter five Ossie takes Teresa "up the path" (p. 59) to the Dyes' house, and in chapter nine he walks "up the Redknapps' [path]” (p. 88). Although in the novel Gee does not state that the higher side is on the east, it seems very likely that it is the actual eastern side he has in mind. Again recalling Newington Road, Orchard Street also has a lower side: Mr Worley's orchard runs "from the back of his house down to the creek" (p. 23). And in chapter nine Mr Redknapp speaks of "go[ing] down" (p. 89) to Mr Worley's place. That it is the actual western side that Gee has in mind seems confirmed in chapter thirteen when Mr Redknapp and Bike look out from the Dyes' section towards the Waitakeres (p. 131) which really are situated in the west.

Recalling the historic Newington Road, Orchard Street has "a blind end” (p. 34). Where farmland owned by an Irish family cut across Newington Road, "an acre of land" (p. 34) owned by the Collymore family (whose Irish descent is suggested by their name) provides Orchard Street's apparent end. Just as a Catholic school was located across farmland behind the Gees' section, a Catholic school is located across the farmland behind the Dyes' place. Where there was once a shed standing on the next door section owned by the Gees, there is a shed on the Dyes' back section that provides a sleep-out for Les.

Gee also uses actual people as sources for fictional characters. Most significantly, the Gees are the models for Eddie and Lil Dye and their two sons - Les and his younger brother Austin (nicknamed Ossie) the protagonist. Like the Gee family, the Dyes are Labour and Pacifist (p. 71). Gee father's interest in horses and betting is recalled in Eddie Dye who "place[s] bets" (p. 33). And his mother's unwillingness to mix socially is recalled in Lil who seems "a snob" (p. 15), who likes "people who [speak] well, [remember] their manners [and] a gentleman [who wears] his shirts buttoned at the wrist” (p. 13). Like Gee’s brother, Gareth (or Gussie), Les works "in a bank on the Great North Road, in the centre of the new Loomis that had grown up since the war" (p. 77), and acts as security guard armed with a gun. Recalling the real bank Junior, Bike Pike shoots a friend with his revolver. Like the young Gee (or Mossie) and his visits to the Harts, the similarly nicknamed Ossie visits Mr Worley across the road to play draughts and borrow novels by Zane Grey and later Charles Dickens. And like Mr Hart, Mr Worley dies from grief after his little dog has been run over. Where the young Gee, hidden amongst pines, spied on pairs of nuns, and found their beads and crosses "sinister and dangerous," Ossie in the pine grove spies on two nuns and dreads their "starched white frames around their faces [and] beads and crosses [that catch] bits of light" (p. 14). 
Further parallels exist between the Gees' and Dyes' neighbours. Like Scott the chemist who lived over the road from the Gees, Mr Pike lives "over the road" (p. 21) from the Dyes and tries in vain to fly his kite on the farmland, then returns home and releases his budgies. On the Dyes' south side live neighbours exactly like the Pinkneys on the Gees' south side, who fought in World War I, make tents, keep to themselves, enjoy classical music, and are childless. Recalling Norcross the bookie, Frank Collymore takes bets and gets "potted" during the Watersiders' lockout. It is clear, then, that Orchard Street is anchored in reality.

\section{Gee's Fictionalisation of Fact}

However, as previously noted, Gee renames Henderson as Loomis, implying something hidden coming into view. ${ }^{12}$ Newington Road becomes Orchard Street, thus stressing that Loomis is still partially rural. But although it would have been 1943 when Gee was thirteen, he sets the novel in 1951 - the year of the watersiders' lockout is when Ossie is thirteen. And where the two ends of Newington Road were actually connected by 1951, Gee retains Orchard Street's "blind end" (p. 34), perhaps to emphasise the dual motifs of seeing and blindness.

Gee also makes telling adjustments to characters. He conflates the Scott, Flynn, and Kay families into a single idiosyncratic family named Pike. Mr Pike tries to fly a kite as Mr Scott once did, and releases his budgies (p. 22). But, like Mr Greenough, Pike has been a railway signalman, wires flowers for funerals and has a son (p. 22). And recalling the Kays, the Pike family practises the beliefs of Radiant Living, sings hymns, and eats nuts and raisins (pp. 21-22). The Pikes strive for natural balance and fulfilment, but they have frustrated, miserable lives. Gee, therefore, establishes contrasting families in the Pikes who are angry, religious and miserable and the Dyes who are Pacifist, irreligious and more content.

Gee alters other families in the street. The Northern Irish anti-Catholic Donohies who lived at Newington Road's blind end become the Collymores who live at Orchard Street's blind end. But in contrast to the Donohies, the Collymores are Catholic and their walls are adorned with "Jesus pictures and bleeding hearts" (p. 37). They also seem excessively friendly. Their backdoor is "always open" (p. 36) and everyone is Frank Collymore's friend. When Mrs Collymore dies her daughters look after the family.

The Pinkneys who lived on the Gees' south side, and who were associated with blue and the National Party become the Redknapps - a name obviously associated with 
red suggesting communism or socialism. Mrs Pinkney's father, Mr Hart, who played draughts with the young Gee, becomes Mrs Redknapp's father, Mr Worley who plays draughts with the young Ossie, but Mr Worley is old, widowed, lonely, and grumpy, whilst the name change may suggest the whirl of chaos. In addition, draughts, chess, Grey and Dickens become metaphors for stages of knowledge and of life. As $\mathrm{Mr}$ Worley tells Ossie in chapter seven: "Draughts is kindergarten [...]. Chess is university", and Ossie observes that "he was disappointed that I was still reading Zane Grey. I was old enough for Dickens, he said" (p. 70).

Gee, moreover, creates characters that are pure fiction. He replaces his childhood friend Murray with the Coopers who live in the street's "first house" (p. 23) and hints at Mr Cooper's brutality to his wife who has "black eyes" (p. 23). And "over the road" from the Dyes, "next door" to the Pikes, lives Mr Raffills who has beaten his sons with tomato stakes (p. 21). Quite deliberately, then, Gee seems to establish Orchard Street as having one side inhabited by those who are peaceful and sociable, another side inhabited by those who are grumpy or brutal, and a further area inhabited by those who are exceedingly friendly and open.

The layout of the street, therefore, falls into three distinct segments that encompass a range of beliefs and behaviours. On what equates to Newington Road's east side dwell pacifist, left wing, and irreligious families. On what equates to Newington Road's west side dwell unsociable, quasi-fascist, and/or religious families. And inhabiting the land at the blind end dwell the overly sociable, apolitical and religious Collymores. Thus Gee reveals his pre-occupation with division and seems to see an analogy between personal and social conflict. Orchard Street becomes a microcosm of $1951 \mathrm{New}$ Zealand and its political and religious factions. With its three sectors, it recalls Susan's realisation in the Motherstone that "three [is] the special number. Three would make things whole" (p. 85), and Gee's own notion of three as a representation of wholeness.

Caught midway between two worlds - the pre-World War II rural world with its orchards and vineyards, and the urban post war world with its industrialisation, and Great North Road to the city and bank - Loomis echoes the street's divisions. Ossie is also at an intermediary stage of development, suspended as he is between the rural and urban, innocence and maturity, and the political east and west, as is suggested by his changing name. He has been known in childhood as "Dinky" (meaning small or genuine), in adolescence as "Ossie" (a colloquial term for communist east Berliners during the Cold War, and perhaps intended by Gee to contrast to the "westies", a colloquial term for those living in Henderson), and in anticipation of adulthood as the 
more sombre "Austin". In chapter one the adult Ossie looks back on his youth to find out who he is and write the novel. Reflecting society's divisions, he must integrate conflicting features of his world and psyche. His examination of his personal history exactly parallels what Gee does by including in Orchard Street real detail from his childhood.

\section{The Lange and Holland Governments}

Gee wrote Orchard Street in 1998, just seven years after the fictional adult Ossie has “written" his Orchard Street. In chapter one the older Ossie's reflection that it is "more than 40 years" (p. 7) since he last saw Bike Pike (which was evidently in 1951), suggests that the year he writes his novel is 1991. In fact, 1991 was significant politically in a number of ways. It was the year of the then widely publicised watersiders' reunion, the Employment Contracts Act, and cuts in welfare. 1991 also came close on the heels of the Lange government. Apparently, then, Gee juxtaposes the era in which he sets the older Ossie's writing of the novel and the period of the narrative proper in order (as I would argue) to emphasise the contemporary relevance of the Holland era.

Echoing world-wide trends New Zealand experienced a thawing of relations with the Soviet Union under the fourth Labour government, which possessed a mandate to oppose nuclear weaponry and power in the Pacific. With a cabinet including many from the sixties' counter-culture, it was led by David Lange who received an ovation when he argued the anti-nuclear cause in March 1985 in the Oxford Union debate. But when the American destroyer USS Buchanan was denied entry to New Zealand waters there was a price to pay. New Zealand was expelled from ANZUS - the pact between Australia, New Zealand, and the United States which agreed to the sharing of defence, particularly against communism. Freed from the anti-communist pact, New Zealand was to embrace Russia and celebrate with the rest of the world the beginning of the end of the Cold War.

New Zealand's expulsion from ANZUS during Lange's era perhaps caused Gee to recall its joining of ANZUS during Holland's era when, following the end of World War II, there was widespread anxiety about Russia, communist expansion, and nuclear weaponry. It was in 1951, under Sid Holland's National government, that New Zealand joined the defence pact with Australia and America and increasingly adopted the Cold War mentality of America where McCarthyism ensured the persecution of communists. ${ }^{13}$

The Cold War mentality permeated New Zealand life and became confused with the waterfront dispute of 1951, a fact exploited by the National government in order to gain popular support, as noted by Mein Smith. ${ }^{14}$ The waterside workers were labelled as 
communists or Russians whilst Sid Holland, ship owners and employers, were perceived as loyal to Great Britain and the United States. The Holland government's Emergency Regulations of 1951, which prescribed the waterside workers' lockout from their place of employment, therefore seemed an extension of the separation of east and west under the ANZUS pact, and the very reverse of what Gorbachev would achieve through "glasnost".

\section{The Novel}

Gee's close interest in the changing relations of New Zealand, America, and the Soviet Union seems to be reflected in Orchard Street in which individual repression may be analogous to national and international repression. Thus Orchard Street echoes the political divisions between the watersiders and the Holland government. A Cold War mentality permeates. By showing Ossie and his family sympathetically as strongly on the workers' side and happy to be labelled "commie lover[s]" (p. 9), Gee seems to reflect Lange's pro-Russian stance that prevailed around the time he sets the older Ossie's writing of the novel. Orchard Street may, therefore, anticipate the warmer attitudes to Russia and Communism that developed with the lifting of the iron curtain. By siding with Ossie and the Dyes, Gee balances the anti-Communist Holland stance of the past, which is represented by Mr Pike. Pike refers to a communist as "a rat", and to union leaders Jock Barnes and Toby Hill as "Barnsky and Hillovitch" whom he would put "up against a wall and shoot [and] send to Russia" (p. 47). Ossie's recollection of the government's claim that the "Waterside Workers' Union [is] run by communists" (p. 10) further recalls Holland's McCarthyism and exploitation of a Cold War mentality.

\section{Roger Douglas's Monetarist Reforms and the Holland Government}

Deeply divided, New Zealand's fourth Labour government has been described as "[straddling] the political spectrum, with one foot in the liberal tradition of welfare and the other in the right-wing tradition of market-oriented economics". ${ }^{15}$ So whilst Gee may have been sympathetic to Prime Minister David Lange's liberal humanism and Labour's left, he must surely have detested Minister of Finance Roger Douglas's implementation of the monetarist reforms of Labour's right. As recorded by Mein Smith, these reforms were seen by many as warfare in that they caused extensive political and social division. ${ }^{16}$

Influenced by the New Right ideology of British Prime Minister Margaret Thatcher, and American President Ronald Reagan, Douglas and fellow neo-liberals based a case for reforms on the stagnant economy of Muldoonism, and argued that 
salvation was to be through the free market. Supported by an elite group from cabinet, Treasury, the Reserve Bank, and the Business Roundtable, Douglas pushed through radical reforms in economic and public policy (including economic deregulation) and in the state and business sectors. ${ }^{17}$ Government functions were cut, privatised, or contracted out and legislatively required to act as businesses. Corporatization developed rapidly into privatization and public asset sales. Laws were called to weaken the unions, and militant employers demanded wage cuts. From 1990 Jim Bolger's subsequent National government pursued the market reforms and extended them to social policy. The Employment Contracts Act of 1991 radically deregulated the labour market and adopted individual contracts in employment whilst Minister of Finance Ruth Richardson made drastic cuts in welfare. ${ }^{18}$ That the reforms occurred with such speed, crusading zeal, and theoretical purity, led many to compare them to a "blitzkrieg", as Mein Smith has observed. ${ }^{19}$

As we know today, the social costs of Douglas's radical reforms were dear. Big businesses, the educated and affluent profited. But, as David Lange later recalled, "the obsession with money overran any form of political, social, human sense". ${ }^{20}$ Moreover, as political scientist Jon Johansson has claimed, the movement towards a freer economy and greater individuality subsumed "cooperation, altruism, and fraternity". ${ }^{21}$ Hardest hit was the agricultural sector with the collapse of rural industries and the rural economy. In addition, hospitals operating as businesses failed to profit and became run down, and small towns lost their post offices. Careers were insecure as restructuring inevitably produced redundancies and escalating unemployment. Unions were constantly under attack and the worker, subordinate to employer and consumer, became a tradable commodity. ${ }^{22}$ For example, the policies and port reforms of Rogernomics (like those of the Muldoon years) had a damaging effect on watersiders. Indeed, Labour legislated the Waterfront Commission out of existence whilst the Employment Contracts Act overrode unions, drastically reduced permanent jobs, and casualised labour. ${ }^{23}$ Threatened by militant employers with redundancy and unemployment, many workers were engulfed by a climate of silence and fear.

Politicians and historians have recently pointed out connections between the Lange government as influenced by Douglas and the Holland government. Such connections may have been made by Gee in the 1990s. In 2005 Mein Smith noted how Holland's abolition in 1950 of government's Legislative Council resulted in a unicameral government that, during the late twentieth century's ruptures, led directly to an unrestricted use of executive power. In both the Lange and Holland governments a select inner few dominated policy making and used and misused power on behalf of a small society. 
Like the Lange government, the Holland government theoretically embraced capitalism and the Anglo-American free market. ${ }^{24}$ Within the post-war climate of the early fifties Holland talked about free enterprise and building "a nation of "little capitalists" to the extent that opponents named his government "Sid Holland's new private enterprise party". ${ }^{25}$ To this end Holland bowed to Britain, and to America, whose dollar he courted. Indeed, in this climate of extreme nationalism Holland's Anglo-American capitalism was seen as a betrayal, particularly of New Zealand's working classes. ${ }^{26}$

Recalling the "blitzkrieg" reforms of Rogernomics, the Holland government's control of labour and the economy were deemed authoritarian and fascist. Politician Sandra Lee has recorded that Holland's Emergency Regulations "represented some of the most draconian laws ever put in place in New Zealand's history". ${ }^{27}$ As Jock Phillips has put it, in 1951 "fascism or German Nazism became the definition of a political evil [and] Holland's radio appearances were likened to Hitler's". Drawing on Dick Scott's comments in Wellington Waterside Workers' Union papers, Phillips adds that Holland was described as "a would-be Mussolini”. ${ }^{28}$

Writing in 2004 about "then" and "now" Bill Andersen (an ex-watersider) emphasises this connection between capitalism and fascism: "Fascism has its roots in the capitalist system New Zealanders live under. [ . . ] If the corporates and their monkey politicians cannot repress, confuse and cow the workforce, they still turn to fascist-like methods like the 1951 Emergency Regulations to have their way". ${ }^{29}$

Ex-President of the Waterside Workers' Union, Chris Kenny, has similarly suggested that the Rogernomics era formed a "full circle" back to 1951 so that "all the old battles need(ed) to be fought again". ${ }^{0}$ Sandra Lee has recalled that "those watersiders and their allies who survived into the 1980s saw earlier than most the ramifications of New Right policies were the casualisation of labour, the destruction of universal welfare, health, education and housing, and restrictions on union activity". ${ }^{31}$ Regular reunions, particularly the reunion in 1991 (reported in the press and in Jock Barnes' memoirs) provided opportunities for watersiders to compare the ruptures of the present with those of the past and to reiterate the vow never to accept a truce. In Jock Barnes' words, they thus declared: "Never a white flag". ${ }^{22}$

\section{The Novel}

Gee, a self-proclaimed socialist, makes similar connections between capitalism and fascism. ${ }^{33}$ He sets Crime Story (published in 1994) in the era of Rogernomics, and depicts laissez faire economics, "grabbers and getters", white collar crime, industrial dispute, 
and social deprivation. ${ }^{34}$ The novel includes the developer Bob Jones along with the fictional Howie Peet (who exploits the free market and attempts to buy airspace). On the other side Gee depicts the unemployed, like Brent Rosser who disguises himself as a student, and his sister Leanne, a beneficiary.

In juxtaposing 1991 (when the older Ossie is writing the novel) and 1951 (the period of the narrative proper), Gee seemingly reacts against Rogernomics by emphasising the damage caused by capitalism in Orchard Street during Holland's era. Thus he shows the conflict between Sid Holland, the wealthy ship owners, and employers on one side; and the unionists, workers, and ordinary folk on the other, and clearly places himself on the latter's side. The Holland government's control of the economy and labour is explicit. In chapter one Ossie reads a wharfies' pamphlet that claims "the Holland government is starving our families [and the] shipowners [who are] sucking fat cigars [are telling workers to] work 59 hours a week or you are dumped" (p. 13). The unpopular affiliations of Douglas and Holland to capitalist Anglo-America are recalled with the slogan “\$id” (p. 93) on Mr Pike’s door. (In 1951 New Zealand's currency was still sterling.)

The increasingly capitalist mentality is emphasised when into the quiet world of Loomis intrudes the self-interested, mercenary investor. A "speculator in commercial building sites" to whom Mr Worley has "sold out" (p. 23), he anticipates the decline of the rural economy and beginning of commercialism. The Lange government's sale of public assets may be recalled when characters sell off their land. Mr Worley, for example, has sold his orchard, which has given "the street its [very] name" (p. 23) and thus contributed to the identity of residents in the street.

Like Bill Andersen, Gee appears to connect capitalism and fascism over different eras of government. In chapter one Ossie's father Eddie compares the battle between the watersiders and Holland to "fighting Hitler," and the "new regulations" to "those in a fascist country" (pp. 10-11), whilst Ossie likens himself delivering propaganda to "spies in the war, with the Gestapo after them" (p. 12). On duty in the bank (emblematic of capitalism), Les and Bike are armed with American Smith and Wesson guns, thus emphasising capitalism's link with America and violence. In chapter ten American capitalism is paired with Nazi fascism when the "\$" sign in Sid Holland's name is matched with a swastika to replace the letter "H" (p. 93).

Gee seems to reflect the impact of the Douglas and Holland capitalist systems on labour, welfare, health, union activity, and community. Most characters living in Orchard Street have only menial employment and have difficulty making ends meet. Ossie's father, a printer, makes extra money from printing at home; Frank Collymore, 
who is self-employed in the cartage business, also works as a bookie; and, as previously mentioned, Mr Pike has been a railway signalman and makes and sells funeral wreaths (p. 22).

Suffering as a result of Holland's politics, characters also cause suffering. Mrs Cooper is beaten by her husband, Mr Raffills has beaten his sons, Mrs Redknapp is severely depressed, and Mrs Collymore, neglected by her husband and terminally ill, is cared for at home and only goes to hospital to die. Mr Worley, who has sold out to the speculator, also suffers and dies: His orchard "lay abandoned. The trees suffocated in blackberry, you could see their wigwam shapes underneath. Mum said it pained $\mathrm{Mr}$ Worley to see them die" (p. 23). By showing that it is those least equipped to deal with Holland's systems that most suffer and that cause suffering, Gee stresses the ill effects of capitalism.

Like Lange and Johansson, Gee seems to believe that individualism and monetarism can subsume co-operation, altruism, and fraternity, and he shows this on a personal level. For example, Frank Collymore's self-centredness is suggested in that he "is self-employed [with] no interest in union affairs" and less in his wife, but a great deal of interest in beer, races, and other women (p. 33). Lil seems to recognise this when she claims that Mrs Collymore is "'more sorry than sick, with that husband of hers" (p. 36). Gee, too, seems to be of the view that self-interest, whether political or personal, may be injurious to the nation, and also to family and friends. Thus the socio-political and individual operate in a cause and effect relation.

\section{The 1951 Dispute}

While Gee underlines parallels between the 1950s and the early 1990s, his depiction of the earlier period is valid in itself. Completely antithetical ideologies rooted in tradition had driven the debate of 1951. Historically, trade unionism and Labour were closely linked. A socialist movement, trade unionism had initially grown as a response to English capitalism during the industrial revolution (approximately 1750 to 1850). It opposed inequality, competition, and divisions of religion, nation, class and race, and claimed that the working man's only property was his labour, which he sold when agreeing to work for a wage. Trade unionism eventually formed its own political party the Labour Party - a coalition with a range of options, including Social Democracy and Marxism. ${ }^{35}$

Traditionally, therefore, Labour favoured equality and people working together within a centralised state controlled economy, and forces of production that benefited 
the worker. Trade unionism, solidarity, fraternity, altruism, and co-operation were predominant Labour ideals, along with the collective, and service of others as opposed to the individual and service of self. A common symbol of socialism was that of workers clasping hands, united in work; as seen on the New Zealand Waterside Workers' loyalty certificate, for example. ${ }^{36}$

In New Zealand Jock Barnes led the workers on the left. A former waterside worker, eventual President of the Watersiders' Union, and with a history of militant unionism, he together with Toby Hill, the national secretary, fought many battles with the governments of both Peter Fraser and Sid Holland. Most commonly these were over hours, cargo, conditions, and pay. It was the impasse resulting from the fight for a forty-hour working week and the removal from the Order of the Waterfront Commission of the clause allowing men to refuse overtime and remain in their jobs, that led to the lockout.

The waterfront drew workers from all backgrounds, including communists, and Catholics, Pakeha and Maori, and immigrants from Britain, Europe, America, India, Australia, and the Pacific. It was thus internationalist. What gave this disparate group its strength was its unity in the face of adversity and camaraderie. In fact, it has been said that "the wharfies' union didn't just have militancy, it had a culture" ${ }^{37}$ Whole families were involved, including Barnes' wife Freda, who was President of the Women's Auxiliary of the Auckland Waterside Workers' Union. ${ }^{38}$

It will be obvious that Capitalism, on the other hand, has been traditionally associated with right wing politics, conservatism, and nationalism, with an emphasis on individualism, separatism, free will and pluralism. Where "equality" from the point of view of the Labour Party involved fraternity and co-operation, it counted for conservatives as equality of opportunity. In the ideal capitalist society, therefore, there is little economic control or regulation and, driven by the profit motive, the individual in private enterprise and the free market is self-serving and competitive.

With strongly capitalist interests the National Party's Sid Holland was Prime Minister of a cabinet that included Keith Holyoake (Deputy Prime Minister, 1949-1957), William Sullivan (known as Big Bill, Minister of Labour, 1949-1957), and W. S. Goosman (Minister of Works, 1949-1957). In addition, the Federation of Labour aligned itself to the National government in 1951. Its top men were equally famous, particularly A. W. Croskery (President, 1946-1953), Fintan Patrick Walsh (Vice President, 1948-1953, and later President) and Ken Baxter (Secretary). ${ }^{39}$

After a series of disputes with waterside workers, Sid Holland declared a state of emergency on 21 February 1951. Dick Scott (editor of the workers' bulletin, Transport 
Worker) has recalled the Emergency Regulations as a "fascist blueprint" in 151 Days (first published in 1952, apparently in spite of right wingers' attempts to "extinguish" both author and book). ${ }^{40}$ Scott has also quoted the clause forbidding support of strikers and promoting the power of the police:

\begin{abstract}
Any person who carries, displays, drives or causes to be driven any vehicle carrying or displaying or fixing in any place where it is in sight of any other person, any banner, placard, sign or any other thing, writes, prints or causes to be written or printed or displayed on any vehicle, wall, fence, erection, road, street or footway or otherwise in sight of any other person, can be arrested without warrant by any constable, and every vehicle and any property can be seized immediately by that constable. ${ }^{41}$
\end{abstract}

With the ban by the Emergency Regulations on publication of the wharfies' viewpoint, supporters were forced to be inventive. Scott has recalled how he, fellow writer Chip Bailey, and cartoonist Max Bollinger (all Communists) resorted to analogy and historical allegory. This is exemplified in a verse published anonymously at the time:

\title{
Sid's Trip to the Moon
}

King Sid lay back with a contented sigh, Everything on the waterfront was lovely.

He rang for his fiddlers three $[\ldots]$

In trouped The Black Prince

With his tame parrot

Who keeps screaming they're all communists.

Lord Scabaxter with his Doubled Cross Charts,

And little Bill who as everybody knows

Is worth his weight in gold. ${ }^{42}$

Of course, the characters of "King Sid", "The Black Prince", "Lord Scabaxter", and "little Bill" refer to Sid Holland, Fintan Patrick Walsh, Ken Baxter and Bill Sullivan respectively.

Driven underground, the wharfies' supporters felt much trepidation about printing the material. As Dick Scott has noted, “The frightening thing about 1951 was that it was a pure police state. [...] Chip, Max and I never used the phone because you had to operate as if you were in a Nazi-occupied territory". ${ }^{43}$ Chip's wife Rona Bailey has recalled that, during the five month lockout, their typewriter was hidden in a space above the pantry and covered with a panel of wood. She also remembers copying bulletins and leaflets: "This was a logistical nightmare. We carried the Gestetner around from place to place. Most of this was done early in the morning - two o'clock until five o'clock. It was not easy. Those old Gestetners were heavy, messy and sticky." The supreme power given to police meant they could raid homes three or four times a night. Bailey recalled her fear when "two hefty policemen" - Dave Patterson and Detective Knapp - entered her home. ${ }^{44}$ 
Delivery was equally hazardous. Bailey would put out leaflets, paste up stickers and posters in the early hours of the morning, or load up her old Riley car and take pamphlets down to the Trades Hall where, in spite of a police presence, they were secretly distributed to watersiders during morning meetings. For Sandra Lee whose family spanned three generations of waterside workers, delivery was a family matter: "One evening my dad, along with my mum's brother Cyril, were distributing illegal union leaflets down by the railway station when they were spotted by police, who gave chase. My father was fast on his feet and he carried out a diversionary tactic so Cyril could escape". ${ }^{45}$

On the other side there was a veritable barrage of abuse against watersiders who were labelled in papers and radio as communists, thugs, beasts, and wreckers. Most notorious were the remarks during parliamentary debate of Goosman, who seemed to promote Hitler's ideas: British - they are worse than transferable diseases and we have to take steps to deal with them.
Goosman: The instigators of the (waterfront) trouble are anti New Zealand and anti
McCombs: Hitler talked in the same way.
Goosman: All I have to say is that if Hitler had to deal with the same thing Hitler talked right. ${ }^{46}$

Worse still, some of the unionists' marches drew outbursts of violence from the police which, under the Emergency Regulations, were sanctioned. On 2 May, for instance, over one thousand watersiders, seamen, and freezing workers marched from Wellington Trades Hall to Parliament to try to convince Holland and Sullivan to reopen negotiations. But on the corner of Cuba and Dixon Streets they were attacked by police and forced to disperse. ${ }^{47}$ Further violence occurred during a gathering of only thirty or forty outside the Chief Post Office in Queen Street Auckland at 5 p.m. on Friday 18 May. Jock Barnes has recalled the event:

\begin{abstract}
While we were peacefully talking, the SS charged with batons flying. Some of the older police acted moderately and fairly, but many of the younger ones relished their unbridled power and acted like the legalised thugs they were. Those of us still standing were kicked, bashed and punched from the Central Post Office to Milne and Choyce. Alec Drennan had been viciously bashed and then thrown into Fort Street. Shoppers or anybody in the way went down or were knocked aside. An 81-year-old man, walking with the aid of a stick, was bashed and kicked for good measure. His legalised basher, as with others of his kind, had gone berserk. [ . . . All that were missing from the scene were the jackboots and swastika armbands. ${ }^{48}$
\end{abstract}

Most violent was the march in Auckland on 1 June 1951. Becoming known as "Bloody Friday", it involved about one thousand watersiders and supporters and proceeded peacefully up Queen Street, along Karangahape Road, and down Pitt Street towards the 
Trades Hall. But opposite Myers Park police rushed the protestors and struck indiscriminately with their batons at men and women alike. ${ }^{49}$

Of course, nothing was straightforward in the conflict between Holland and the workers. Some members of Holland's government did not support him - the Labour opposition was incensed about restrictions on strikers' meetings, publication of their points of view, and donations to their families. ${ }^{50}$ And opposition leader Walter Nash was notorious for refusing to take one side or the other, as his comment at a TUC rally confirms: "We are not for the watersiders, and we are not against them". ${ }^{51}$

There were also people who changed sides. The terms "scab" and "rat" were used to describe those disloyal to the left who had their names published on a "flat beer list" or roll of dishonour as a mark of shame. ${ }^{52}$ Most hated of all "scabs" were Fintan Patrick Walsh and Ken Baxter of the Federation of Labour. Walsh had been born in 1894 as Patrick Tuohy to a large Irish Catholic family in Poverty Bay but had changed his name, religion, and political affiliations several times. In 1915, after travelling to the United States, he became involved in Chicago's gangster world. Subsequently influenced by Irish radical Jim Larkin, he became a staunch unionist and communist - a "Marxist bully boy" - and joined Sinn Fein and the IRA.

In 1920 Walsh returned to New Zealand and joined the Communist Party where he met with Ken Baxter. Acquiring the moniker of "the black prince" (first used in the Red Worker in 1932) he worked on the waterfront, joined the union, and eventually became a member of the Federation of Labour, and vice president in 1946. Walsh then worked closely with Labour Prime Minister Peter Fraser and, using mafia-like tactics, became known as "Fraser's Muscle Man”. Having ditched Catholicism, Communism, and Unionism, Walsh was considered by watersiders as selling out his side. When the National government came to power, Walsh became Holland's henchman and exercised an aggressive control of unionists. His alignment to the Fraser and Holland governments completely split New Zealand's trade union movement between the conservative Federation of Labour and the Communist influenced Trade Union Congress whose major component was the Waterside Workers' Union led by Barnes. ${ }^{53}$

In late May, at a meeting held in Auckland's Town Hall, Barnes launched a verbal attack on the policeman who had manhandled the elderly man during the incident earlier that month. For this, on 7 July, he was charged with "criminal defamation" and jailed. His case was heard in August when, found guilty, he was sentenced to two months' hard labour. On 12 September the final figures came in for a snap election called by Holland. They ensured National's return, the dismissal of an appeal by Barnes, 
and a victory against unionists and watersiders who between 7 June and 16 July had gradually returned to work. ${ }^{54}$

\section{The Novel}

Gee depicts a divided society and gives weight to opposed yet mixed sides. But he seems to compensate for the Holland government's victory in 1951 by depicting the left side more sympathetically. For example, just two pages into the novel we are presented with an authentic reproduction of the waterside worker's certificate designed by Dick Scott, which promotes the positive ideal of standing "loyal right through" reinforced by the familiar image of workers clasping hands united in work (p. 8). Furthermore, Ossie and the Dye family are on the side of the left. As Ossie says in the opening chapter: "All I'll say is that I sided with Dad. It was workers against ship-owners, workers against Slippery Sid, but it was a family thing for me. Us against them" (p. 9).

Thus the Dyes echo the watersiders' ideal of loyalty, and Labour's traditional principles of solidarity, fraternity, co-operation, and serving others before self. Like the historical watersiders and their supporters, they feel the impact of Holland's Emergency Regulations on their lives. Aware that aiding the strike is an offence, they anxiously draw their curtains and lock their doors. Echoing Scott and the Baileys, Eddie and Lil hide their Gestetner and typewriter behind a wooden barricade beneath the house. Lil writes up the propaganda and Eddie prints it off. Lil finds that "the secrecy and danger [are] wearing her down” (p. 42). Recalling Bailey and Lee, Ossie and Les deliver leaflets to neighbours' boxes at night. As Ossie comments: "When I went out delivering I knew it was more than a movie or a game. I was afraid" (p. 12). His fear is justified in chapter twelve when, like the real raids experienced by the Baileys, the police raid the Dyes' home and arrest Eddie.

Gee's sympathetic portrayal of those on the left allows the reader to understand why some changed sides. In chapter seven, for instance, Eddie prints "the flat beer lists" and "rolls of dishonour" which name "scabs" (the "Jim Smith and Joe Brown") who have betrayed the wharfies" cause. But then Eddie tells Ossie that they are "just trying to keep their families fed" (p. 69). Propaganda typifying the right is echoed when Ossie reads a newspaper account of the politicians' attack on wharfies as "greedy loafers and wild beasts [and as] savage and filthy and foul" (p. 51). But set against this are the Dyes who sympathise with the wharfies and who are certainly not greedy, wild, savage, filthy, or foul.

The violence that really occurred in 1951 during the wharfies' marches is integrated into the novel to show that it is those on the right that are thugs. For 
example, Eddie has apparently read a newspaper report of the Cuba Street incident in Wellington, on 2 May. He then enjoys doing exactly what Gee does in writing the novel. By giving an account of the other side's story he corrects the balance:

\begin{abstract}
[Eddie] was enthusiastic doing leaflets that told what the police and the government were up to - describing a fight in Wellington where 10 of the wharfies ended up in hospital. The papers couldn't say what their injuries were - and didn't want to, Dad said, because they were on the bosses' side. Dad's leaflet made it clear that most of the wounds were cuts on the head from police batons. He liked printing that sort of thing, to set the balance right. (p. 69)
\end{abstract}

Similarly, in chapter twelve Lil seemingly recalls Bloody Friday's violence on 1 June, but corrects the newspaper's biased report. That "the wharfies were beaten [and that] evil foreign doctrines had taken an honest British kick in the pants" is therefore amended by Lil to read "a belt on the head with a baton, more like" (p. 111). The setting of this chapter, explicitly on "Saturday [... ] July 7, 1951" (p. 121), and its retrospective account accommodates the return to work of the real miners and seamen in early July.

In compensating for the victory of the right in 1951, Gee demonstrates less sympathy for right wingers. Mr Pike is consumed by hatred. In chapter four he is "burning-eyed" when advocating the shooting of communists, and adds, "Do you know three things I hate? [... ] A communist, a rat, and a communist" (p. 47). Ossie's quotation of Goosman's notorious assertion that "Hitler talked right" (p. 72) similarly distances the reader from Holland and supporters like Mr Pike.

Gee further corrects the balance by publishing in his novel, previously banned leftist propaganda, particularly where it depicts those joining Holland's side in an unfavourable light. Thus Eddie and Lil print "poetry" referring to "Sid's Trip to the Moon [ . . ] the Black Prince $[\ldots]$, Lord Scabaxter [...], the Tame Parrot", and the actual line: "They're all communists, the Parrot screamed' (p. 42). Lacking explanation, Walsh's and Baxter's defections are seen unsympathetically when compared to those on Eddie's flat beer list, whilst the screaming Parrot (someone who squawks the party line) seems vicious. ${ }^{55}$

\title{
Orchard Street's Broader Significance
}

However, Gee goes much further than replicating personal and political history and providing a corrective balance. He underlines political divisions by projecting them geographically on to Orchard Street. Characters are not only influenced by politics, but also experience versions of strikes, lockouts, bargaining, arbitration, scabbing, and economic negotiations, and often parallel real political figures. 
The fictional street's east side is inhabited by workers and their sympathisers. Eddie, "an ardent union man" (p. 10), is employed in a printing business and he and Lil have a social conscience. In printing the wharfies' propaganda, significantly in a sort of workshop - "a little print shop" (p. 10) under the house - they labour unpaid for their fellow human beings. In loyally assisting her husband, Lil recalls Rona Bailey and Jock Barnes' wife Edith, whilst Eddie resembles Chip Bailey the printer, and Barnes. That Eddie is eventually jailed on Saturday 7 July, exactly the same day as Jock Barnes was charged and jailed, confirms not only his sympathy for the workers, but also him as a partial parallel to Barnes, their leader.

On the same side, of the street and politically, the Redknapps too are sympathetic to the wharfies. In chapters one and seven Mr Redknapp gains Ossie's trust by advising against papering his letterbox (p. 19) and warning him of Mr Pike (p. 73). In addition, the Redknapps make their living by sewing tents and knapsacks, and so are actually workers with a "workroom" (p. 15) built onto their house. Recalling the unionists' principle of cooperation, they help each other out. When Mr Redknapp has "a coughing fit" Mrs Redknapp holds "his head on her huge breast until it [is] done", and when Mrs Redknapp stands "in the roses, crying silently" Mr Redknapp dries "her eyes with his handkerchief' (p. 15). Furthermore, they explicitly resemble the wharfies, as Ossie observes when watching them in chapter one: "Sometimes [Mr Redknapp] had trouble lifting the canvas and [Mrs Redknapp] ran to help, shouldering the heavy stuff like a wharfie" (p. 15).

The characters on the other side of the street include Mr Raffills (who has beaten his sons), Mr Cooper (who has beaten his wife), and the Pikes (who are aggressive and unfriendly). That Les paints the \$id Holland slogan on the Pikes' garage door suggests Mr Pike may be the counterpart of "\$id Holland" in Orchard Street. Pike's hatred of communism, Barnes, Hill, and Russia (p. 47) echoes Holland's McCarthyism. Subscribing to an American religion (Radiant Living), the Pikes recall Holland's proAmerican stance. As a railway signalman involved in giving commands, and capitalising on death to sell funeral wreaths, Mr Pike may embody the authoritarian, mercenary attitude of Holland and his command economy.

"Back the other way" (p. 21) from the Pikes, Mr Worley, living on Orchard Street's west side, also seems politically conservative. He dislikes communists and their supporters whom he sarcastically terms "our red friends" and "a pack of villains" (p. 71). Moreover, selling his orchard to the speculator, he in effect plays the free market and gives up the land that gave the street its name (p. 23). He also engages in "direct bargaining" with Ossie, trading off Zane Grey's novels for playing draughts which he likes to win. Recalling Sid Holland's cabinet who took New Zealand into World War I 
on the side of Great Britain, Mr Worley fought as "a major" during "the first war" (p. 75), and speaks in an "English voice" (p. 24). Old and ailing, he perhaps reflects the diminishing influence of a class-ridden England during the waterfront dispute. Gee thus fuses the personal and political, and fact and fiction, to create characters and a novel that are resonant and whole.

But Gee does not simply give a one-dimensional view of families and divisions in Orchard Street. Recalling the "mixies" in the $O$ trilogy, families and individuals are shown by Gee to be realistically mixed. On the east side, the Dye family are left wing and pro working class: Lil can "laugh like a barmaid" (p. 33). Nevertheless she "likes people who [speak] well and remember their manners" (p. 13) and is a snob (p. 15). As Ossie records in chapter three, "She came from a family that had more money and education than Dad' and she believed in 'things of the mind'. Polite behaviour, nice thoughts. Elevated thoughts" (p. 34). Les betrays the family's socialist values in a different way. He works in a capitalist institution (the bank), has his own brand of business which is "enjoying himself' (p. 53), and aims to become an employer. He therefore seems to pursue values related to individualism, power, freedom, and serving self. Ossie similarly betrays the socialist ideals of unionism, solidarity, and fraternity. By cutting Bike out of friendship with himself, Les, Teresa, and Eileen, he echoes Holland's lockout of watersiders. And although socially minded, the Redknapps live behind closed doors and a boundary hedge of macrocarpa that has never been cut, effectively locking others out.

Those on the street's west side are equally mixed and subject to change, for Gee does not caricature them as total villains. Mr Raffills has beaten his sons, but his wife and sons have locked him out and made him cry: "Mr Raffills used to beat his sons [...] until one night all three ganged up on him and threw him out of the house and locked the doors. $\mathrm{Mr}$ Raffills roared like a bull and banged on the walls, but after a while sat down on the back steps and cried" (p. 21). Mr Cooper has beaten his wife, but it is she who effectively "scabs" by eloping with a painter. The Pike family may be right wing, aggressive and unfriendly, but Bike is more sociable and repeatedly approaches Ossie in friendship. And although Mr Worley is conservative, a capitalist, and promotes self-sufficiency, his notice "help yourself" (p. 23), referring to the box of fallen fruit outside his gate, implies a generous act. In addition, his recollection in chapter seven of Nash's actual claim to be "neither for nor against" (p. 72) suggests that not only is he the ironic opposite of Nash, but also of Holland, in that he is neither for nor against either side, but against both. As he tells Ossie in chapter seven, "Both lots are a pack of scoundrels, Holland and Barnes" (p. 72).

Gee's interest in creating mixed sides and characters extends to the Collymores at the blind end. Like Walsh, absconding from Catholicism, Communism, and Unionism, 
Frank Collymore practises neither Catholic ideology nor political commitment. As Ossie notes, Frank and Eddie Dye "were good mates, although Frank was self-employed and had no interest in union affairs - union hoo-ha, he called it" (p. 33). In fact, Frank recognises no religious, political, social or economic boundaries. He treats every woman to a "Gidday, gorgeous" (p. 33), blows them kisses, and offers them rides in his truck. He allows his own business (Collymore Cartage) to run down, and exploits the "free market" by pirating vehicle parts and working illegally as a bookie. Orchard Street, therefore, becomes a microcosm of New Zealand's waterfront dispute of 1951, and of the complex and varying relationships between self, society, and governing power.

\section{International and Familial Divisions}

Allusions in Orchard Street to World Wars I and II and the Cold War call to mind international divisions and enormous cross-currents. These impinge on the novel and appear to be part of characters' consciousness. Gee seems to see analogies between personal and political disharmony on the one hand, and individual, national and international disharmony on the other. He therefore explores the larger dichotomies of left and right, Russia and America, communism and individualism, socialism and fascism, and society and self as expressed through the novel's characters.

Responding to the street's climate of silence and fear, characters who are left wing and pacifist act out war in their everyday lives. Most obviously, Les's aggression is suggested in that he lives in an army hut and enjoys gun play. In chapter eight "wearing a balaclava and a black jersey and black trousers" (p. 95), and described as "a thug" (p. 97) by Mr Pike, he recalls the "Black Shirts" (the British Union of Fascists led by Sir Oswald Mosley) and Nietzsche's savage beast (Hitler's model for Nazi youth). ${ }^{56}$ In painting the swastika on Pike's door, Les may unwittingly be exposing a quasi-Nazi aspect of himself.

The "\$id Holland" slogan on Pike’s garage doors emphasises his aggression and right wing affiliations and, furthermore, suggests that he (as well as Holland) resembles the Nazis. Moreover, the proximity of the swastika and dollar signs within the slogan implies the similarity of Nazi fascism and American capitalism. But Bike contradicts his family's political stance. As a member of a rugby team he participates in a social activity: "He played on the wing for the Loomis colts and [ . . ] scored some good tries when his team-mates managed to put him in the clear" (p. 22). Moreover, Bike is friendly and gracious on social occasions. In sports he is "as graceful as an antelope" (p. 22). When 
serving in the bank he smiles and says "It's a nice day, madam. Thank you, sir" (p. 48). And dancing with Eileen Collymore, he moves "with grace and speed" (p. 55).

Ossie, then, is not only situated between the dichotomies represented overall by the Dye and Pike families, but also between Les and Bike who contradict their families' political ideals. For personal wholeness he must integrate these sides: the fascist or west side represented by Les, and the socialist or left side represented by Bike. Like Les, Ossie performs the role of spy, as he acknowledges in chapter one: "I'd been spying on [the nuns] since I was five" (p. 14). This separates him from "the collective" represented by his family and neighbours. His delivery of the wharfies' pamphlets takes him "out in the cold" (as the jargon of Cold War espionage puts it) and at night he crosses the political divide to spy on Orchard Street's “superpowers". Thus he accesses others' intimate, often violent lives: "I scuttled through the light and into the dark and slid along, hearing doors open and dogs bark and bits of conversation from lighted rooms. I heard Mr Raffills blowing his nose. I heard Mrs Cooper say, 'If you hit me one more time I'm going to the police"' (p. 13). Ossie tells his mother: "It's like spies in the war with the Gestapo after them" (p. 12), but invading others' privacy he himself resembles the Gestapo. Indeed, were it not for Mr Redknapp's invitation to view the galaxy, Ossie, again like Les, would be painting graffiti on Pike's garage doors, as he mentally notes: "I wanted to go with [Les] and maybe climb the tower, but knew he wouldn't wait for me to change" (p. 96).

Ossie also resembles the existential hero or "man alone" that Communism reacted against and sees himself in terms of American individualism as depicted in Zane Grey's romantic The Lone Star Ranger with its solitary, stoical cowboy Buck Duane. Moreover, Ossie imagines Duane's enemy - the outlaw Poggin - to be present in Orchard Street. As he comments in chapter one: "When I went out delivering [ . . . ] I started seeing the enemy, Dad's enemy and mine, as a man who looked like Poggin, with rippling muscles and yellow eyes" (p. 13). Fact and fiction merge. Western small town New Zealand and Loomis (described as "the garden city of the west", p. 81) fuse with America's Wild West, and ironically Ossie, a "westie" (as previously noted, a colloquialism for an inhabitant of Henderson), becomes an imagined cowboy hero.

Rather than consistently demonstrating Communism's positive ideals of loyalty, fraternity and solidarity, then, Ossie fuses quasi-fascism and individualism, and typifies the west's less desirable traits. Drawing on American popular culture, he operates alone. In chapter nine he does not wish Teresa "to be lumping [him] in with Les" (p. 81) whom he calls "King Kong" and "Donald Duck" (p. 99). In chapter twelve he mentally separates himself from his rugby team and comments: “I didn't want [Teresa] to see me plodding round in the pack" (p. 114). With nuclear warfare on his mind, Ossie sees the 
Dyes' typewriter as "heavy as a bomb [and] ticking like a bomb" (p. 41), as might a spy during the Cold War. And in chapter ten he betrays his side by revealing Eddie's hidden typewriter to impress his girlfriend, Teresa.

Ossie's appropriation of Zane Grey's Lone Star cowboy, Jupiter, and real stars in the "globular cluster" (p. 18) reflects his egocentric dream of heroism and transcendence. But in chapter one his ascent to the rooftop to spy on the Redknapps' complementary relationship and reduce it to the comic, suggests his inability to understand human imperfection and affection:

I climbed on the roof and hid behind the chimney and watched them making tents in their workroom. [ . . . It seemed all wrong to me that people as old as the Redknapps, and fat and thin, and sick as well, should behave like that. It made them ridiculous and it troubled me. (p. 15)

In literally and metaphorically placing himself above others, Ossie reacts against the human factor - Mr Worley's yellow teeth, Bike as initially gentle and peaceable, and the Redknapps' frailty and love. Thus his arrogance and puritanical ideals prevent him empathising with people to whom, politically, he claims to be aligned. In 1951, then, Ossie is suspended between childhood and adulthood, Les and Bike, and cold and hot wars, and also between the real and fictional, and socialist and quasi-fascist sides of himself.

\section{Spiritual Beliefs}

Two pages into the novel the older Ossie asks himself a difficult question: "Who was I, who was Bike, who was Teresa - and Eileen, Les, Mr Redknapp and the rest?” (p. 8). He thus seems to acknowledge the interconnectedness of himself and others. In the novel spiritual as much as political beliefs influence people, and thus seem to inform Ossie's character. The conflict between self, society and superpower is therefore echoed in the individual's relationship to God, which Ossie considers on a number of occasions.

Gee's references to Catholicism and Radiant Living - two very different versions of Christianity - reveal his interest in antitheses. The beliefs of Catholicism are well known, but Radiant Living needs some introduction. A "new age" religion (dating from earlytwentieth-century America and brought to New Zealand in 1938 by Herbert Sutcliff), it advocates temperance, self-control, and knowledge of self as three-fold - the mind, body, and soul - and their balance in order to reach God. Exponents of Radiant Living believe nature is pure and that the self must become attuned to it through a natural balanced diet, exercise, music, fresh air, sunshine, water, rest, positive attitudes, and affirmations. A trust in God contributes to a harmony with the radiant soul that is the invisible source of good. 
Where Catholicism emphasises a perfect God separate from the fallen individual, and the relinquishment of self to God in order to achieve perfection and transcendence, Radiant Living believes that the individual is in God, and that through control of self he/she may achieve perfection and transcendence. ${ }^{57}$ As we shall see, Gee also suggests beliefs connected to atheism (the implicit and explicit denial of God, and valuing of self), and agnosticism ("the view that nothing is known, or likely to be known, of the existence of God or of anything beyond material phenomena"). ${ }^{58}$

In Orchard Street Ossie encounters a confusion of spiritual and political beliefs. He becomes acquainted through the Collymores with Catholicism, through the Pikes with Radiant Living, and through Lil, Mr Worley and Mr Redknapp with versions of atheism and agnosticism. But each character has a suppressed side. Therefore, Ossie also becomes acquainted with underlying beliefs that are contradictory.

Frank Collymore, for example, is Catholic, but has seriously lapsed. His neglect of politics is paralleled by his neglect of God and earthly goals. He therefore resembles the practical atheist whilst his sons Jimmy and Mike are unsociable and aggressive. It is primarily through Eileen and Teresa that Ossie sees in practice the Christian principle of putting family and others before self. Upon visiting the Collymores' house, he observes them caring for their dying mother: "There was an open door into the lounge and sometimes I'd glimpse one of the girls helping Mrs Collymore out of the bedroom. She groaned as she walked. She wore red slippers with yellow pompoms. The calves of her legs were wasted away, making her shins as sharp as angle iron. The girls kept her long grey hair combed and tied in a ribbon" (p. 37). In that Ossie is in love with Teresa, she can be said to embody his ideals, particularly in her mothering role as nurse or caregiver.

However, Teresa is not completely selfless. Upon her mother's death acting as mother to her family, she bitterly complains: "I'm just the servant" (p. 112), thus echoing Lil's words under duress, "I'm not a servant" (p. 43), and also demonstrating a lack of Christian humility. Cleverer than Ossie, she wants to ascend not through subordination of self and discovery of God, but through self-assertion and control of others. That Ossie dreams of Teresa in chapter eleven as Ganymede - "the moon that wouldn't come out" (p. 101) - may suggest he recognises within her an assertiveness more commonly associated with masculinity. But by the end of the novel Teresa seems to exercise self-control. Becoming a dietician, she recalls Mrs Pike and Radiant Living's emphasis on temperance, nutrition, and balance.

The Pikes also contradict their belief of Radiant Living for they are anything but radiant. Their hymns, "marching songs" that include "Lemons in the Morning" (pp. 21), 22) together with their stringent diet (avoiding salt and sugar), suggest the militaristic and 
bitterness. More aggressive than Christian, Mr Pike echoes Nietzsche's man is God as opposed to Radiant Living's individual in God. ${ }^{59}$ His desperate desire for transcendence is suggested by his attempt to fly his kite and the release of his budgies, whilst his lack of harmony with nature is echoed in his wiring of flowers. Mrs Pike, described by Ossie as "loopy" (p. 45), is similarly unbalanced whilst her outbreak of boils suggests suppressed passion. Bike who is "tall and thin, with clothes-peg shoulders and grasshopper legs, clumsy and gawky" (p. 22), is physical evidence of the Pikes' spiritually narrow lives.

Of the Pike family only Bike has a Christian attitude, but in contrast to Radiant Living's belief in asserting one's self, his attitude recalls Catholicism's emphasis on humility. Seeking purity in Eileen, Bike seemingly expresses a Catholic view of the mother figure. In chapter ten, effectively crucified on the barbed wire fence, his hand cut and bleeding, and distracting his father to save Les, the gentle, peaceable Bike seems almost Christ-like - an irony emphasised by Les's words: "Jesus, he's fast" (p. 96). But in chapter thirteen, echoing Les's revolver play and sexual penetration of Eileen, Bike erupts emotionally and shoots Eileen. Thus he becomes almost quasi-fascist. At the same time, like Christ, he is a scapegoat in that he suffers at the hands of others (including Ossie) who project their aggression onto him and exclude him from friendship and love. It is his final "crucifixion" on the pine tree in chapter thirteen that contributes to Ossie's growing awareness and assumption of responsibility for others. In effect, therefore, Bike saves Ossie's soul.

Initially aggressive and an atheist in that he lives as though God does not exist, Les is the direct opposite to Bike. However, upon marriage he converts to Catholicism, and at the end of the novel recalls the lapsed Frank: "Les had some sessions with a priest and became a Catholic just before the wedding [ . . . . He drank beer with his father-in-law, but rarely too much" (pp. 135-136). Similarly atheist, Lil distrusts all religion, as Ossie observes in chapter three: "We, the Dyes, didn't have a religion. You didn't need one, Mum said, to be a good person" (p. 34). He comments: "Mum frowned when she saw [a priest or nuns] in the street, but she did that with anyone religious, Presbyterians, Anglicans, the lot" (pp. 35-36). According to Ossie, Lil believes in "things of the mind" (p. 33-34). She also demonstrates humanistic attitudes and tells Ossie: "Say you're nothing, if anyone asks. Say you believe in the human race" (p. 34). But Lil's advice contrasts to her actions and implicit beliefs. Ossie observes that "things of the mind" for Lil equate to "Nice thoughts. Elevated thoughts" (p. 34) as opposed to knowledge of human nature or the self.

Having fought a capitalist war, and read Zane Grey's "blood and thunder" (p. 30) novels in youth, Mr Worley is quite the reverse in 1951. Rather, it is the manipulation 
of the kings and queens during games of chess that now comprises "war", whilst his wisdom seems to be based on the novels of Dickens and his moral approach to Great Britain's capitalist industrial society, and victims of poverty and crime. Certainly Dickens' humanism seems to be echoed in Mr Worley's explanation of the Redknapps' tragic history in chapter seven: "He looked at [Ossie] a moment - a kind of measuring look. 'Well,' he said, with the expression of sadness [ . . ] 'she's depressed. It's a breakdown. [ . . ] My daughter Winifred lost her baby, you see. [...] That's their story, Austin. It's different from Zane Grey"' (pp. 73-75). Sharing his insights with Ossie, Mr Worley represents old age and wisdom.

Mr Worley also conveys his knowledge and wisdom to Mr Redknapp who has fought alongside him in war, played draughts with him, and read Dickens. Mr Redknapp's understanding of his wife, and advice to Bike (learnt retrospectively by Ossie) that "when you do certain things you've got to take the consequences" (p. 137) suggest he has humanist and pragmatic principles. Furthermore, he draws on the classics, arts, and sciences for his beliefs and introduces Ossie to astrology, astronomy, Galileo's mathematical principles, and ancient myth, thus representing middle age, and also knowledge and wisdom himself.

That Mr Redknapp recognises the possible but unknowable existence of God suggests he may be an agnostic. But in chapter eleven he and Lil reveal underlying beliefs in Christianity. Lil, in rejecting "grace", nevertheless seems momentarily to acknowledge God as giver ("We think that enjoying food is thanks enough", p. 105) - a point that is taken up by Mr Redknapp who asks who she is thanking. As Ossie observes, she is forced unconvincingly to explain: "Mum blinked. None of us had ever trapped her as neatly as that. But she was equal to the challenge. "The farmers who grow it. And the workmen who bring it home for their families"” (p. 105). Lil implicitly acknowledges the power of grace (and her own superstitions) when she admits crossing her fingers whenever it is said. And she assumes a belief in Christ's existence when she comments that "Jesus was a good man, but mistaken" (p. 106).

Mr Redknapp acknowledges Christianity but within limits. He admits to being a churchgoer (although he qualifies the statement by adding "not in a regular way") and confesses to a belief in hell's existence (that he qualifies by adding, "It's just not where the preachers say"). And he seems to question Lil's denial of Christianity by repeating "I wonder", and claiming "Wonders never cease" (pp. 106-107). A quotation from Dickens' The Pickwick Papers, these words confirm that he, like Mr Worley, has a view of life based on literature. Lil's quotation of the third line from Robert Browning's poem, 
"Rabbi Ben Ezra" proves that she, too, is influenced by literature and the Christian viewpoint that the poem argues, as is suggested by its first stanza:

Grow old along with me!

The best is yet to be,

The last of life, for which the first was made:

Our times are in His hand

Who saith, "A whole I planned,

Youth shows but half; trust God: see all nor be afraid!” (i, 1-6) ${ }^{60}$

The confusion of different beliefs introduced by Gee together make for a certain wholeness - perhaps suggestive of the psyche. Certainly, if Ossie is to develop a fuller awareness, he must consider these contradictory ideals.

\section{Orchard Street as a Symbol}

In Orchard Street spiritual and political beliefs fuse. Metaphors connected to World Wars I and II and the Cold War are applied to the street which literally experiences cold and hot temperatures. For example, in chapter ten it is "clear cold early-winter weather" (p. 94) outside, whilst inside Ossie's mother makes him burn Teresa's letters. And in chapter twelve the "cold wind [ . . ] blowing down Orchard Street into the drive" (p. 112) is set against Jimmy's and Mike's aggression when they "place a beer bottle on a stump and [start] firing at it with shanghais" (p. 112).

Meteorological changes, cold and hot warfare, and the freezing or thawing of international and national relations are echoed on emotional and sexual levels. In chapter eight "fuzz-balls in the drizzle"(p. 85) anticipate Ossie's unshed tears at Jimpy's death. Conversely, through possessing Jupiter (a gaseous hot planet) Ossie becomes impassioned and falls in love. Les describes Eileen sexually as "too hot" (p. 39) for Ossie, whilst in older age he loses "some of his spark" (p. 135). Excluded from human warmth, Bike Pike appears emotionally restrained or cool, but is inwardly passionate and hot.

Metaphors of height and depth connected to the street's east, west, north and south sectors reflect political and spiritual beliefs. That characters whose ideals involve equality, fellowship, humility or selflessness live on the street's higher side is ironic, for it is on the upper eastern side of the street that characters attempt to transcend mortality. Here Ossie climbs the pine tree to spy on the Redknapps, Lil expresses her snobbery, Les dominates Eileen in his army hut halfway "up" the section, Bike (up the pine tree) shoots at Eileen and Les, and Mr Redknapp climbs the pine to save him. Since the sale of Mr Worley's orchard (on the low side), it is on Flynn's paddock (the common ground 
on the high side) that Mr Pike flies his kite, that Mr Redknapp and Ossie roam the skies, and that Ossie appropriates Jupiter.

That characters concerned with transcendence, individuality, division, and selffulfilment live on the street's lower western side is similarly ironic. For it is to this side that characters go to seek friendship, equality, and fraternity. Here, Ossie meets with Mr Worley and Mr Redknapp and learns about draughts, chess, Grey, Dickens, and life's stories, and through Mr Worley and Jimpy comes into closer contact with death.

The vertical movement up and down the street is equally ironic, for more socialistically oriented characters live at the upper or northern end, whilst individualistic or aggressive characters live at the street's lower southern end. Thus, in travelling north or "up" (p. 41) the street to its blind end, Ossie sees a version of socialism in the friendly Collymores whose doors are open, and in Frank who, Eddie notes, "would say cobber to the king" (p. 90). And in travelling south, "back the other way" (p. 21), or "down" (p. 23) Ossie sees versions of individualism and quasi-fascist brutality in $\mathrm{Mr}$ Worley, who lives alone, and Mrs Cooper's bruised eyes respectively.

Horizontal and vertical movements that are physical and geographical, that cross east, west, north and south, covering heights and depths, become a metaphor for mental movement and are crucial for wholeness, as such movements are also in Susan's experience of $\mathrm{O}$. An ironic hero/adventurer, Ossie mentally and geographically traverses all points of the street in his pursuit of knowledge and wholeness. His and others' changing beliefs, reflected in patterns of ascent, descent, directionality and crossovers are positioned within the novel's overall circular structure. Thus the street becomes a symbol of Ossie's psyche in echo of the collective psyche of society.

\section{Intertextuality}

Ossie's pursuit of wholeness also involves knowing a larger body of literature for, like so many of Gee's novels, Orchard Street contains several literary allusions. To consider but a few: in chapter two, describing Mrs Redknapp “as loose as sand inside her silly dress” (p. 26, italics mine), the younger Ossie is given by Gee words from 'The Angels' Control of the Elements" written by Enoch (the ancient prophet and seer, known as "Enoch the Wise"). The passage in question is remarkable for the delicate balance it achieves, as is suggested by its first lines: "For when the lightning lightens, the thunder sounds, and the spirit at a proper period pauses, making an equal division between them; for the receptacle, upon which their periods depend, is loose as sand." ${ }^{1}$ That the passage's focus is on balance, and the even distribution of water makes it ironically relevant to Orchard Street where the 
very reverse of balance exists. In his lack of insight, uncharitable attitude to Mrs Redknapp's mental imbalance, mixing of idioms, criticism of Bike for mixing his, and denial of Bike's need for emotional nourishment, the younger Ossie is far from achieving Enoch's insight or balance. In a different sense, Sid Holland also deprives the wharfies from water, work, wages, and physical and spiritual nourishment. Gee, therefore, seems to have in his own mind Enoch's passage first as a corrective of characters' personal imbalance in Orchard Street, and second as a reflection of the ideal balance he himself pursues himself through integrating the antithetical sides of the street and its characters.

Further allusions to literature occur in chapter eleven, significantly entitled "Poetry" (p. 101). As we have seen, Lil quotes a line from "Rabbi Ben Ezra" by Browning: "The last of life for which the first was made" (p. 107). But a double irony occurs as the words not only suggest the possibility of Lil's underlying Christian beliefs, but also reveal her deeper romanticism: Browning's argument in favour of Christianity (apparent in the quoted line) is dependent for definition on its opposite - the carpe diem philosophy: "Since life fleets, all is change; the Past gone, seize to-day" (xxvi, 156). ${ }^{62}$ In a further contradiction, then, neither Lil nor Mr Redknapp remains true to the view that fulfilment lies in the "last of life" as the quotation unlocks suppressed yearnings and they seize the day. Thus Lil is comparable to Nietzsche's passionate beast whilst Mr Redknapp also starts to change. That they discuss "Nature, big N" (p. 108) evokes romanticism and also, perhaps (more specifically), the transcendentalism of nineteenth-century New England. ${ }^{63}$ Most significantly, Lil is revealed to Ossie as someone capable of intense emotion, rather similar to the passion he has felt for Jupiter, and started to feel for Teresa:

\footnotetext{
Her head was back and her nostrils flaring. We were terrified of these transformations - of her excitement and her vehemence. Dad had not discovered any way of stopping her.

[... It struck me that Mr Redknapp, free from his wife, was also turning into someone he had once been. They started on poetry again, then art and music and Nature (big N), and Mum wasn't flirting any more, but opening a lid and letting out things she hadn't known she still possessed. (pp. 106, 108)
}

A reading knowledge of Dickens' books is crucial to Ossie's increasing maturity. As we have seen, when Mr Worley dies, Ossie inherits his box of Dickens' novels. As the older author, Ossie realises in chapter eleven that these comprise a valuable gift: "I'll say now, that several years later I pulled [the box] out and started reading, and understood the value of Mr Worley's gift" (p. 105). Dickens' influence on the older Ossie (and on Gee) is apparent in that he imitates the structures of Dickens' novels when writing Orchard Street, as he comments in chapter thirteen: "A story has to stop somewhere. I'll just try to do what Charles Dickens did, tie up the ends” (p. 135). 
Words from Dickens are integrated seamlessly into the novel. Chapter eleven, for example, contains a quotation from The Pickwick Papers. Ossie hears Mr Redknapp echoing Pickwick's manservant, Sam Weller: "Wonders never cease" (p. 107). ${ }^{64}$ Pickwick's world of nineteenth-century industrialised London, with its impoverishment, crime, and brutal prison system seems relevant to Orchard Street with its similar sociopolitical emphasis. It, too, depicts an increasingly industrialised world, poverty, and crime, and sombre prison scenes are anticipated in chapters twelve and thirteen when Eddie, Frank, and Bike are taken off by police. Like Dickens, Gee raises questions about duty, especially to one's friends, family, and employer. Loyal to Mr Pickwick (later imprisoned for his humanistic principles), Sam relinquishes his girlfriend and commits a "crime" so he can accompany his employer to gaol. Thus the older Ossie has a means of viewing his past betrayals - of Jimpy, Bike and Les, and of his father when he revealed the secret printing press to impress his girlfriend, Teresa.

Orchard Street, therefore, reflects those very texts that give it resonance and takes its fuller meaning and shape from them. These texts extend the novel's context far beyond New Zealand in 1951. Surrounding Gee's novel, they effectively hold it still as does the novel's grounding in historical reality. As we shall see, such texts implicitly help the older Ossie's writing to progress beyond the limericks composed in chapters three and eleven. Ossie thus needs to be a reader as well as a writer to become whole.

\section{Cosmic and Human Dimensions}

Gee places his characters not only in "society" and "literature," but also in a magnificent and beautiful universe that seems to be an alternative to religion and the nearest he (and Ossie) get to escaping the world. Through understanding the vastness of the cosmos, Ossie approaches an understanding of the human condition.

Ossie is introduced to the cosmos in chapters one and ten when Mr Redknapp tells him about Jupiter, its surrounding planets and moons, and the stars of the Southern Cross. But Gee emphasises Ossie's division by juxtaposing his appropriation of Jupiter in chapter one against his relinquishment of Jimpy in chapter two. Jupiter and Jimpy are antitheses - the first is a planet, the second is a beast. However, in many ways they are also subtly similar. Both are shades of black and white, and are gaseous - Jupiter has zebra stripes and comprises hydrogen and helium, Jimpy is grey and emits bad smells and both are also personified.

However, Jupiter is distant and unattainable. Ossie sees "him" as "huge and impossible $[\ldots]$, a gas giant $[\ldots]$ bigger than a thousand earths $[\ldots]$ hanging silent 
out among the stars" (pp. 18-19) - a "king of the gods" (p. 96). To Ossie, Jupiter is a superpower - romantic, eternal, and unattainable - and his very flaws (the stripes) make him seem more exciting. Interestingly, it is by looking up and to the right (suggesting the directional, the correct and the political) that Ossie gains a fuller picture: "My eyes came right and the planet was there, filling the lens - invading me. Jupiter. At first I gasped, then I held my breath. To tell the truth, I felt like crying. I'd never seen anything so beautiful before" (p. 17). Jupiter awakens in Ossie a previously unfelt passion, expressed in his desire to possess the planet. He thus tells Mr Redknapp 'Thanks for Jupiter" to which Mr Rednapp replies, “That's all right, Austin. He's not mine". And that night Jupiter fills his "half-dreams" (pp. 18-19). Effectively in love with Jupiter, Ossie desires to be a super power himself.

Jimpy on the other hand is close, tangible, and real, and his flaws - his dirtiness, smell and hindrance of Ossie's movements - are reminders of the mortal. It is down and to the left that Ossie should look to see Jimpy who initially lives with the Dyes on the street's left wing side, and who shares features with other characters. For, old and grey- haired like Mr Worley, short-legged like Eileen, sad and comical like Bike, Jimpy is a conflation of many essentially human traits. This Ossie realises in chapter seven: "Mr Worley was getting older quickly, and so was Jimpy. Their stomachs rumbled in duet. [... ] Mr Worley, like the dog, might not have much time" (pp. 70-71). In giving Jimpy to $\mathrm{Mr}$ Worley and offering to chain him up, Ossie effectively betrays a family member and frees himself from what he sees as impure. Jupiter and Jimpy thus provide antitheses that, in seeking self knowledge and wholeness, Ossie must reconcile.

That Jupiter effectively becomes part of Ossie and is personified by Mr Redknapp as "he" (p. 13), allows Gee to extend the planet and other cosmic forces as a metaphor for the political or human family. For Jupiter is two and a half times the mass of all other planets combined, with immense gravity that holds its moons in its magnetic field and compresses his interior to generate fire. ${ }^{65}$ Hot, gaseous, and potentially explosive, Jupiter is therefore a cosmic version of the superpower, political leader or family head. Gee emphasises this role by extending Mr Redknapp's comparison of the cosmic and the human: "Mars is solid, like us" (p. 18); to include Jupiter's "family": the planets Mars and Saturn (pp. 18, 96), and the moons Io, Europa and Ganymede (p. 95).

Gee's reference to two "female moons" and one "male" moon (who as a mythical character was desired by Jupiter) and lack of reference to Jupiter's fourth moon (Calypso) allows him to establish a further symmetry of three, and ironic parallels with Orchard Street's divided daughters and sons. For, although closely attached to his godlike parent planet, Ganymede is caught in and deformed by the gravitational 
rhythmic beat of Jupiter and his sister moons, which causes excessive inner heat that erupts as liquid water and scars his icy surface. ${ }^{66}$ Reflecting Ganymede in microcosm, Bike is caught in and deformed by the interactions of his family and friends (including sisters Eileen and Teresa). Repressed, he generates an inner passion that causes an emotional eruption and scarring when he shoots Eileen.

Jupiter and "his family" are thus reflected in microcosm in Orchard Street's families and warring forces. Indeed, Ossie uses the macrocosmic context to understand himself and others in chapter eight: "After I turned my light out it was the Redknapps I thought of. I tried to see 30 years of living like that, with burned lungs and a baby that had died. Sometimes I seemed to get close to it, the way I sometimes got close to understanding [...] through Mr Redknapp's telescope, how far it was to Jupiter" (pp. 75-76).

Stellar structures and movements further contextualise Orchard Street. Again Gee emphasises tripartite divisions. In chapter one Mr Redknapp describes to Ossie the Southern Cross's brightest star, which comprises two binary stars - the bright yellow Alpha Centauri A and the orange Alpha Centauri B - and a third, very dim, small red dwarf, Proxima Centauri. In fact the binary stars share a centre of gravity and orbit each other elliptically over eighty years whilst the red dwarf takes millions of years to orbit completely around the two, and exhibits violent flares lethal to life on earth:

See there, the Southern Cross. That bright star in the pointers is Alpha Centauri. But it's not just one, it's three, going round each other. Proxima Centauri is in that system too. It's the closest star to Earth ... after our sun. (p. 18)

As depicted in the novel, the Southern Cross belongs to an image cluster of stars and crosses. These include the Southern Cross (visual emblem of New Zealand on the unionists' loyalty certificate, p. 8), Ossie's Lone Star Ranger (p. 13), the nuns' crosses (p. 14), Bike Pike's film stars (p. 25), and the swastika in "Holland" (p. 93) which altogether suggest different beliefs and ideals. Indeed, Alpha Centauri's triple star system is echoed in the interactions of characters who undergo patterns of exchange and reversal similar to characters in Gee's other novels. ${ }^{67}$

In being closely entwined and interdependent, Gee's main characters intimate the balanced whole - symmetrical and still, and yet including imperfection, conflict and change. When Bike meets Ossie in Auckland's downtown square years later, he seems to understand the relative insignificance of human experience: "A lot of the time $[\mathrm{Mr}$ Redknapp] talked about his life. About the war and getting gassed, stuff like that. I guess I saw how you can go on. And what a small part of my life Eileen was going to 
be" (p. 137). Ossie, too, must understand the universe - and scientifically as opposed to romantically - in order to understand himself and characters on Orchard Street, especially Bike whose suffering he has partly caused.

\section{Conclusion}

Gee allows the younger Ossie to reveal his limitations in his poor attempts at love poetry. The limericks that he writes in chapters three and eleven sacrifice serious meaning for rhythm, rhyme and ridicule, and have circular structures (with the same syllabic count, rhythm and rhyme in first, second and last lines) that compare unfavourably with those of Browning, Dickens and Enoch. The limericks also reflect Ossie's desire for heroism and superiority. In his first limerick he promotes himself by poking fun at Bike: "A skinny young fellow called Bike/Grew legs far too long for his trike" (p. 37). And in his second limerick he egocentrically profiles himself: "A pretty young girl called Teresa/Had brothers who wanted to tease her,/But a fellow called Dye/Was a sensible guy/And spent his time trying to please her" (p. 103).

However, the older Ossie reflects a greater knowledge of literary and cosmic structures. Indeed, it is part of his "labour" - the act of writing - effectively to capture and hold characters still. For characters' mental, physical and geographical permutations surround the central chapter seven which, entitled "Draughts" (p. 69), depicts not only the game but also the whirl of mortality. For instance, Mr Redknapp takes a "breath of fresh air" (p. 71). His "breathing [makes] two different sounds" (p. 71). Mr Worley's breathing "[sounds] like his son-in-law" (p. 74). And a "little whiff of gas" (p. 75) has caused Mr Redknapp's "burned lungs" (p. 76). However, central to this chapter is an image of stillness. The trinity of the younger Ossie, Mr Redknapp and Mr Worley, represents the stages of man - youth, maturity, and old age - with the last two anticipating what Ossie will one day become. ${ }^{68}$ Again, then, it is three held briefly in balance that are necessary to form a tranquil whole.

Furthermore, in recalling the past tangle of mixed characters and beliefs, the older Ossie provides the novel with several frames that intimate an almost geometrical, harmonious design. An inner frame is formed by his memory of Auckland's downtown square where he meets Bike in chapter one, and to which he returns in chapter thirteen. Significantly the meeting takes place in the exact location of the historic gathering of 18 March 1951 when police attacked a small group of unionists. But, some forty years after the lockout, the fictional meeting in Post Office Square is peaceful - an irony emphasised by the presence of a Maori chief, once a warrior, now a statue. ${ }^{69}$ An outer 
circular frame is formed by the older Ossie's point of view, located at the book's beginning and end, in his act of writing the novel and tying its ends together (p. 136). And a sense of stability within a known universe is attained through the novel's integration of, and connections to, historical, cultural and cosmic dimensions.

Thus the novel is patterned and paradoxical. Gee creates a unity that characters individually do not have, but collectively form. Through Ossie he challenges his reader to make sense of human experience whilst he himself exercises a governance that is inclusive and wise. The novel's structure resembles a mandala. It seems to evolve naturally, it has a circular frame, integrated opposites and a consciously realised centre. Of Gee's historical novels for children, it is perhaps Orchard Street that most perfectly symbolises his ideal whole. 

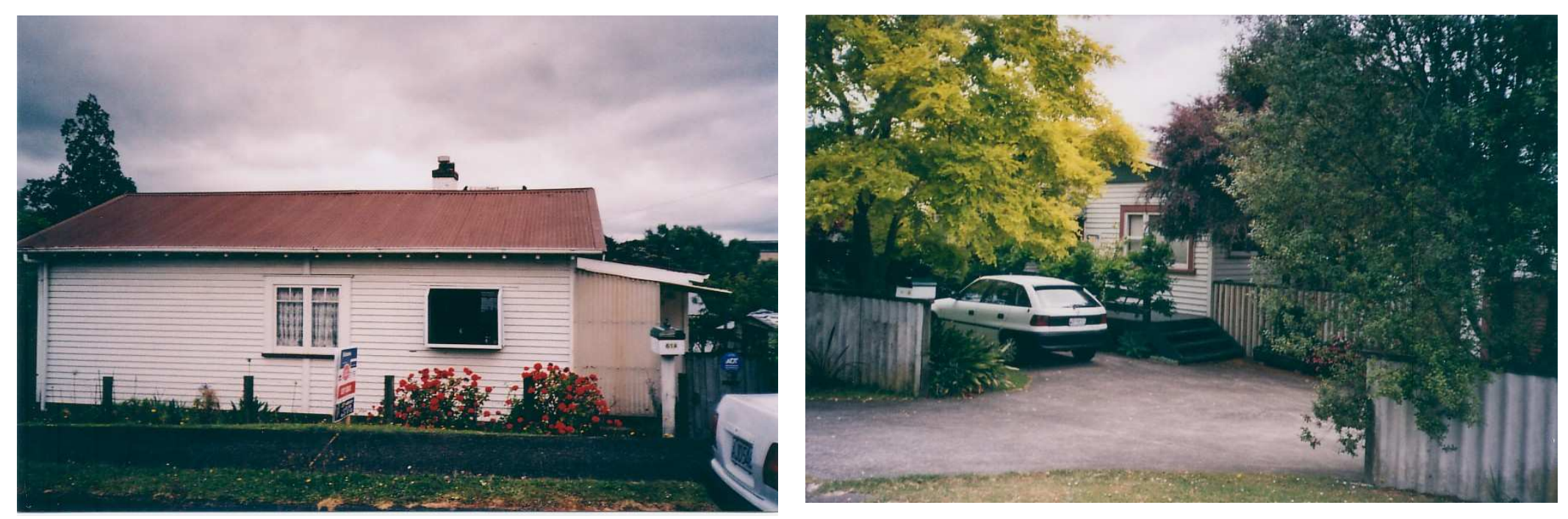

$Z$
$Z$
Y
$z$
$Z$
0
0
0
$Z$
0
0
0
0

FIGURE 13

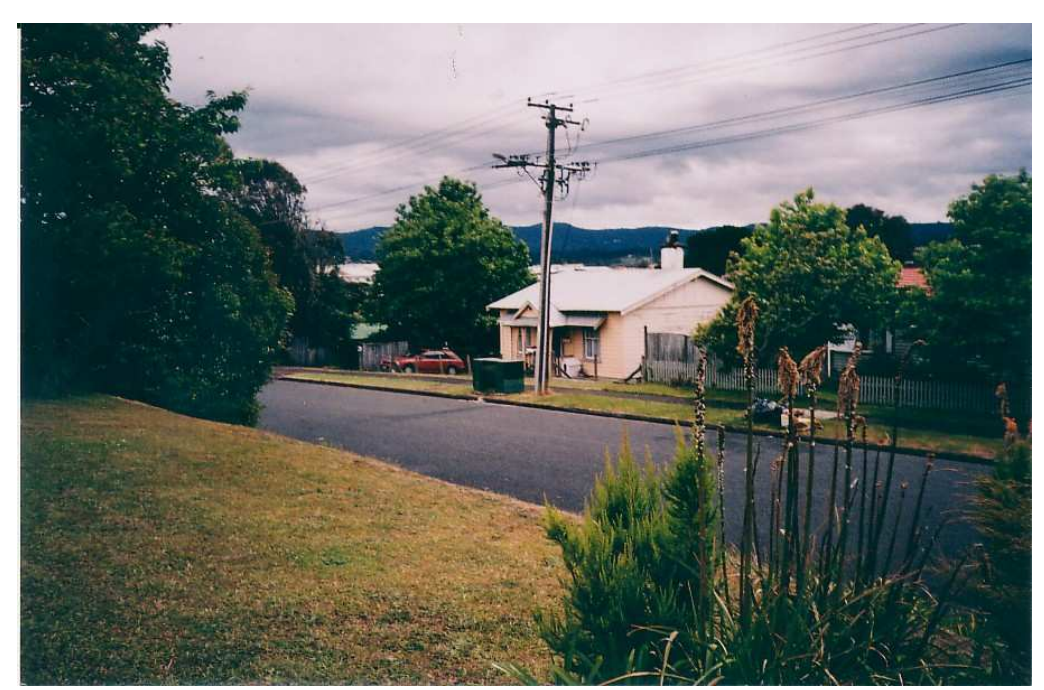

FIGURE 15

\section{FIGURE 14}

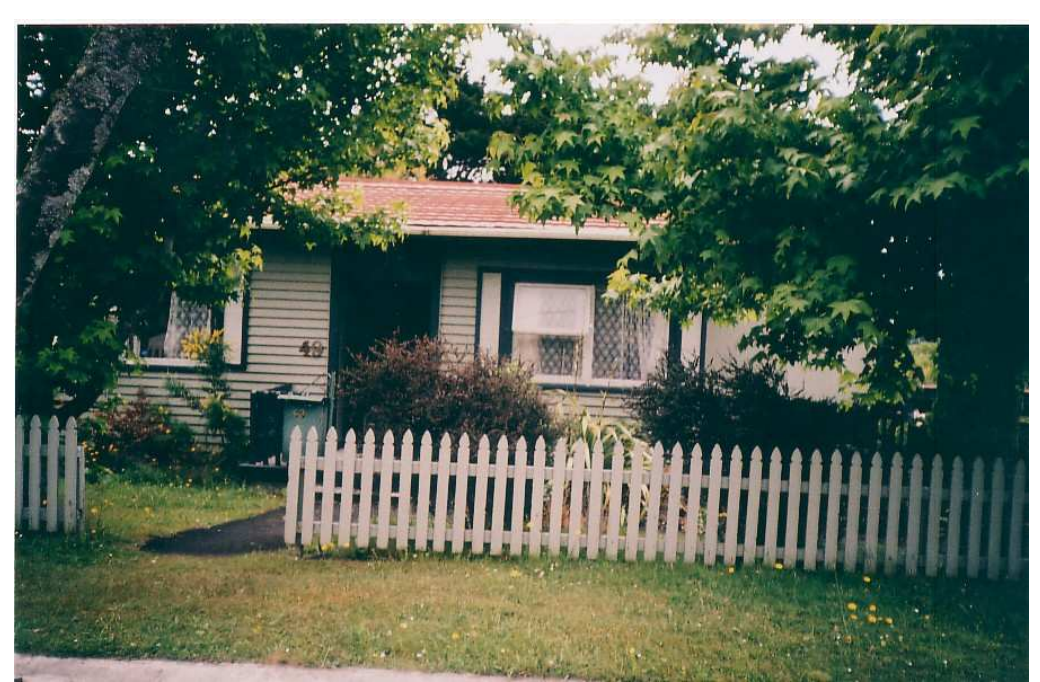

FIGURE 16 


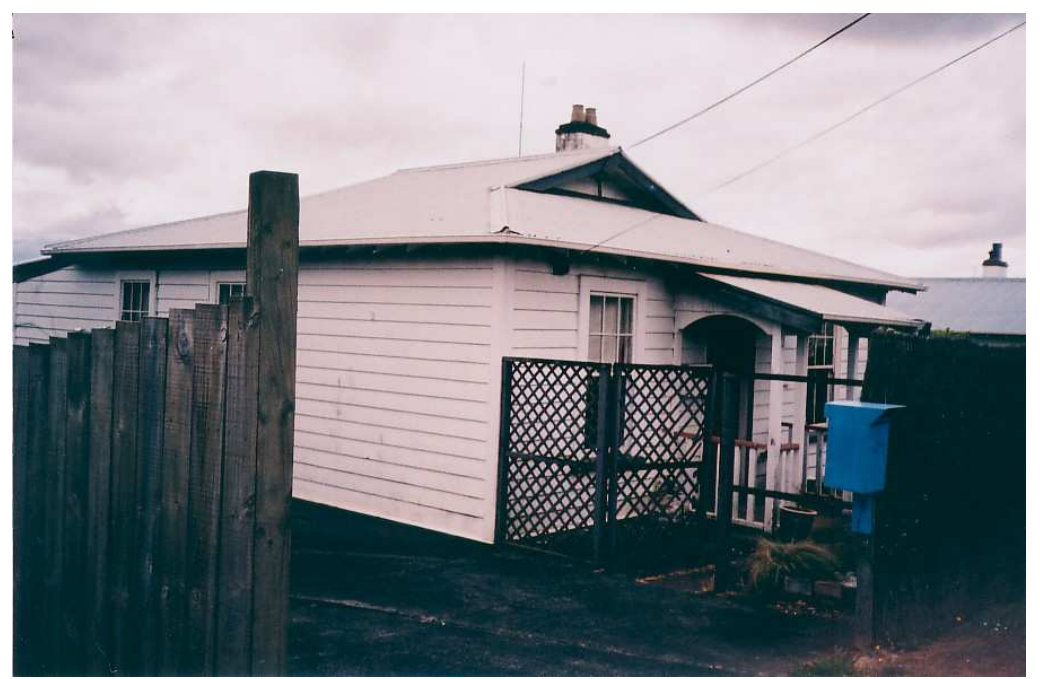

FIGURE 17

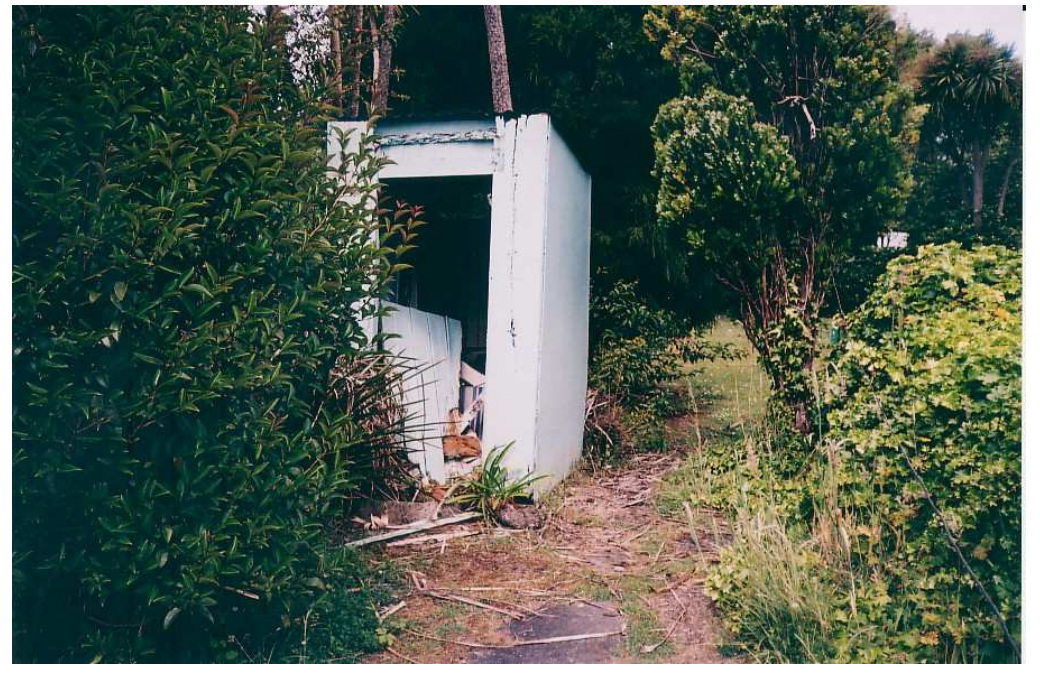

Figure 19

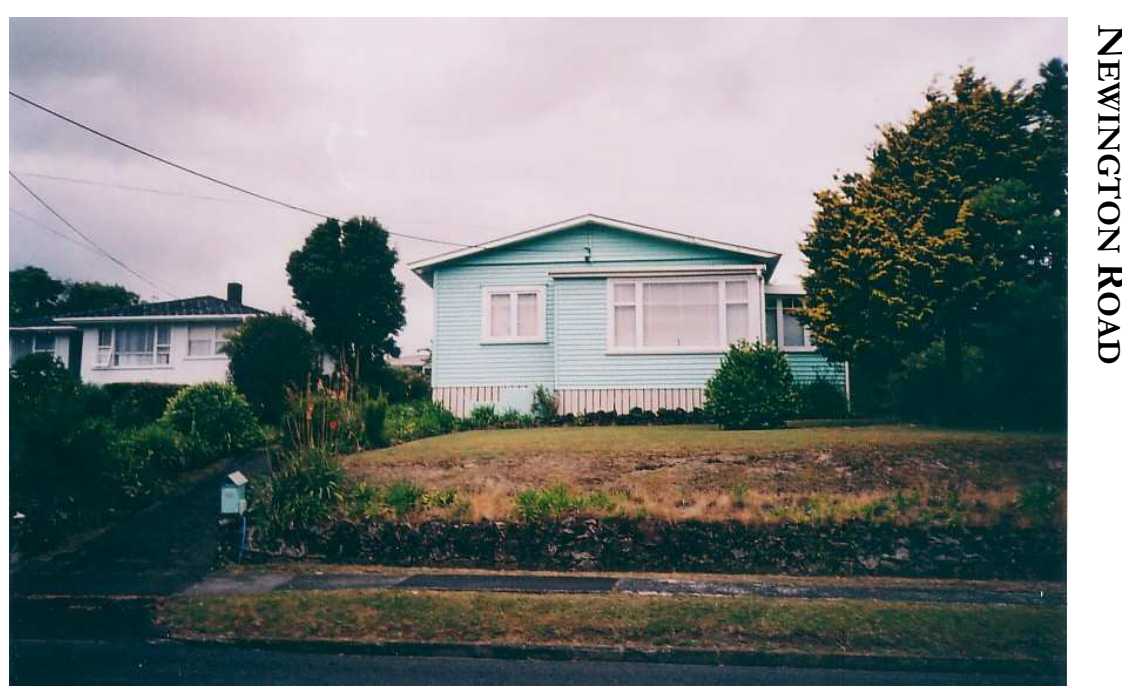

FIGURE 18

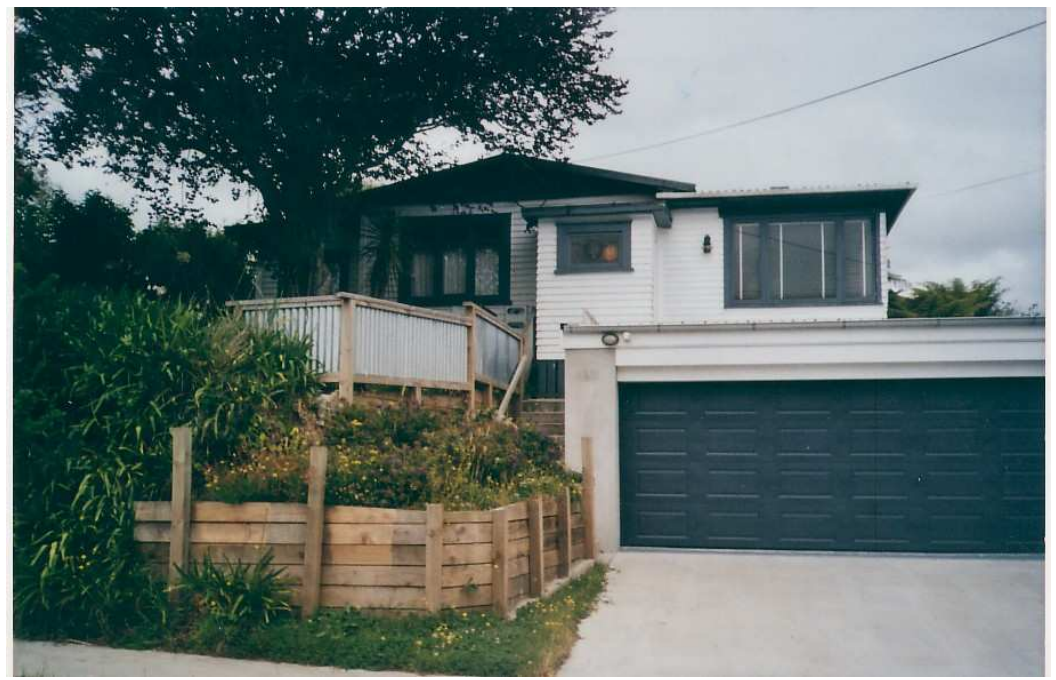

FIGURE 20 


\section{CHAPTER 7}

\section{Hostel Girl}

\section{Introduction}

Hostel Girl is the fifth and final of Gee's historical novels for children. ${ }^{1}$ It contributes to patterns established by the previous four novels as Gee works systematically through crisis points in New Zealand history. As well as representing a further forward movement in time, it shifts from rural to urban settings, and its child protagonists are older. A divided society is again portrayed. Set in 1955 during clashes between popular American and traditional (quasi-British) cultures, and rebellious teenagers and conservative adults, Hostel Girl is located in the suburban Hutt Valley with its cinemas, milk bars, and rail link to the city. Where in The Fire-Raiser the uncouth Edgar Marwick represents society's amoral or animalistic side, in Hostel Girl the cultured Errol Parkinson represents society's moralistic side and, superficially, its desire for purity. Mirroring society's divisions Ailsa, like earlier protagonists, is split between the two.

\section{Personal History and Present Reality}

As we have seen, Gee's historical novels include the real and personal as part of the whole. Hostel Girl is no exception. Gee has acknowledged that his wife's diary provided a source for Hostel Girls female perspective: "I had a wonderful piece of good fortune because Margaretha lived in the Woburn hostel and kept a teenage diary. The detail was all there about what it was like to live in such a place 50 years ago - the dances, the characters, the friendships and the six-monthly roster of nurses coming in and out. I couldn't have written that aspect of the book without it". ${ }^{2}$ Gee has explained: "Margaretha lived in the Woburn hostels for three years when she was 14-16. Her mother was a matron of what was known as House 4, which housed the dental nurses. She has mentioned it from time to time, but the great favour she allowed me was to let me read her schoolgirl diaries which she kept for three years. And the whole hostel background is there $[\ldots]$, the books she was reading, the movies she was going to, her friends, the sport she played - all that sort of stuff was in these little diaries that she kept". 3

Obviously, then, the diaries included detail on the Hutt Valley in the 1950s. Much of that past Hutt Valley remains today. Situated between the Akatarawa and Rimutaka ranges in the north and (beyond Petone) Wellington Harbour in the South, it is 
bordered on the east by the Wainuiomata Hills and by the Western Hutt Hills on the west. The Eastern Hutt Valley still features state (and ex-state) housing. Although no longer accommodating dental nurse trainees, the building that housed them is easily recognisable with its two double storey blocks, each structurally divided into four (see figure 21). Located in Cambridge Terrace, it is one block away from the site of the now demolished Prince Edward Cinema. Across the road Woburn Station still stands, and the old wooden overbridge with its white arc, ramp access on one side and staircase access on the other continues to span the railway line (see figure 22). From it the hostel can clearly be seen.

Running parallel to Cambridge Terrace, Oxford Terrace and adjoining streets in the Western Hutt Valley remain characterised by walled and high-gated mansions set in large gardens (see figure 23). The Hutt Recreational Ground with its pavilion and brick and iron wall, and the gracious Chilton Saint James School (see figure 24) also remain, although a Chinese restaurant has replaced Elbe's Milkbar in High Street.

\section{The Novel}

In Hostel Girl Margaretha and her mother become models for Ailsa and her mother, who is indeed the matron of a hostel for dental nurses. The real hostel's setting is exactly echoed in the fictional one, which is situated in Cambridge Terrace, across from Woburn Station, and parallel to Oxford Terrace. Recalling the real overbridge, the fictional overbridge has a ramp access and views. Ailsa "[wheels] her bicycle up the overbridge and [sees] the valley spread out east and west [and how it runs] north to the mountains $[\ldots]$ and south to the harbour" (p. 5). Like the real overbridge the fictional overbridge also has a stairway access. In chapter two "Gloria [goes] down from the bridge with all the poise of an actress descending stairs" (p. 29). From the overbridge Ailsa looks back to the hostel which, echoing the real one, has "eight houses [and] is two storeys high", her house, like Margaretha's, being number 4 (p. 6). Typifying the real Western Hutt Valley residences, the Pages have a large house, a tennis court, and a "garage $[\ldots]$ as big as a house" to accommodate their two cars and yacht (p. 10) whilst the Recreation Ground is nearby. Similarly, the private girls' school of Chilton Saint James is recalled in Willowbank, "an all-girls school run by the church" (p. 8). Thus in Hostel Girl Gee faithfully replicates a real place. 


\section{From Mazengarb to Feminism}

However, the social climate of the Hutt Valley depicted in Hostel Girl is very different to that of the Hutt Valley today, for Gee sets the novel in the conservative mid fifties following the publication of the Mazengarb Report in 1954. ${ }^{4}$ Established to investigate delinquency in young people, the Report was steered by a committee headed by Dr Oswald Chettle Mazengarb. As noted by Redmer Yska, Mazengarb was a trusted ally of the National Government and Sid Holland, a Baptist, a Mason, a devoted father, a worshipper of Churchill, and "a puritan moralist with a simplistic view of society based on the Ten Commandments". Moreover, the committee as described by Yska comprised: "Anglo-Saxon, middle-class professionals; a team of upright citizens who could be relied upon for strong religious and moral codes. No social workers, educationalists, or those with 'hands on' experience of 'problem' adolescents were included". 5 Nor were any of the children involved actually interviewed as the Report was due for completion by 20 September 1955, and tabled in Parliament nine days before the house rose for the November election. ${ }^{6}$

The Mazengarb Report demonstrated extremely prejudiced attitudes. Particularly targeted were homosexuals, adolescents, females and lax parents (including working mothers), declining family life, new ideas, and a drift from organised religion and morals. For example, the Report noted that "senior pupils of an intermediate school were concerned in depravity, both heterosexual and homosexual" and blamed juvenile murders in New Zealand on an increase in homosexuality. ${ }^{7}$ Specifically commissioned in part because of what became known as "the Parker and Hulme case", it emphasised that the teenagers were murderers and also homosexual: "Two girls, each aged about 16 years, had been arrested in Christchurch on a charge of murdering the mother of one of them. It soon became widely known $[\ldots]$ that these girls were abnormally homosexual in behaviour". 8

In fact, this case became notorious in New Zealand. Of a working class background, Parker lived in the family's boarding house which was run by her mother, whilst Juliet Hulme, from an upper middle class family that had migrated from England to Christchurch, lived near Canterbury University where her father was Rector. Both families were irregular for the times. Parker's parents were not married as her father was still married to someone else. Hulme's mother was having an affair with a boarder in the full knowledge of her (albeit absent) husband. Meeting in a private single sex secondary school, and finding its conservative system stultifying, the girls took refuge in milkbars and cinemas, and worshipped screen idols like James Dean and singer Mario Lanza. $^{9} \quad$ When threatened with separation, their obsessive view of life as a Hollywood 
movie took over. In the vain hope they could remain together, they bashed Parker's mother over the head with a brick in a stocking in June 1954. Convicted of murder, and separately imprisoned, they never met again.

Parker and Hulme aside, the Report was also commissioned because of certain incidents in the Hutt Valley, and cited numerous cases of "sexual laxity among children and adolescents" living there. It attributed the laxity in part to co-educational state schools and precocious girls who were not held accountable for permitting indecency, carnal knowledge, or indecent assault on boys. ${ }^{10}$ Thus the Report took a strong stance against "pre-marital relations" and contraception (described as "a shock to respectable society"), and recognised religious faith as a positive influence on morality. ${ }^{11}$ The Report also targeted American popular mass culture, and Hollywood, and recommended the control of "visual and auditory influences" such as pulp fiction's "tales of intimate exciting romance", posters and advertisements featuring "sex and sadism", "inappropriate" films and trailers, and radio's "suggestive love songs" and "crime serials". ${ }^{12}$

In response to the report, Parliament rushed through the Indecent Publications Amendment Bill, the Child Welfare Amendment Bill, and the Police Offences Amendment Bill. Anticipating re-election, Holland decided that the Report would be distributed free to New Zealand families (which suggests that Gee, in his early twenties at the time, might have read it). But, as Yska has recorded, police, the press, and Truth had blown up events in the Hutt Valley out of all proportion and New Zealand was on a course back into a Victorian past. ${ }^{13}$

In writing Hostel Girl in the late 1990s Gee seems to react against the Mazengarb Report and demonstrate attitudes typifying the counter-culture that had its gestation in the fifties and sixties when he was a young man. Mein Smith has described feminists of the time as "young, educated baby-boomers - anti-racist, anti-sexist, and socialist [who] campaigned for peace, the environment and revolution". ${ }^{14}$ The description seems apt for liberal males, including Gee. A self-proclaimed socialist and pacifist, supported financially by a working wife whilst at home writing novels, and care-giver to his children after school, he was part of a trend that in the 1980s and 1990s respected feminist ideals. ${ }^{15}$ Perhaps, then, it is Gee's interest in contemporary feminism that led him in Hostel Girl to explore a period in which feminists struggled to be heard.

Tomboyish, forthright, and atypical of the Mazengarb era, Ailsa may be modelled on New Zealand feminists of the 1960s to 1990s who were part of the women's liberation movement. These feminists participated in "consciousness raising" activities such as marches and public protests, and successfully fought for employment 
opportunities and pay equal to men, and the right to abortion, birth control, and the contraceptive pill. Through their endeavours New Zealand women were more easily able to choose between motherhood and employment. The introduction of the Domestic Purposes Benefit in 1973, and "no fault divorce" in 1975, and the establishment of Women's Refuge and Rape Crisis centres, gave women (including solo parents) further choices and independence.

The widely publicised women's suffrage centenary in 1993 would have increased Gee's awareness of feminist issues. Furthermore, in the late 1980s and 1990s the rise of several women to positions of power could not have escaped Gee's attention. These included Dame Catherine Tizard (appointed first female Governor General in 1989), and Dame Silvia Cartwright (appointed first female High Court Judge in 1993, and later the second woman to be appointed Governor General). During this period New Zealand also had its first two female Prime Ministers - Jenny Shipley in 1996, and Helen Clark elected in 1999. ${ }^{16}$

However, as observed by Mein Smith, an ideal of early feminism was that of "the colonial helpmeet, representing society's moral guardians and the 'mothers of the race"' ${ }^{17}$ Long-term this movement spawned females who combined strength and independence with the traditional role of caregiver or nurse. The tomboyish nurse Sister Elizabeth Kenny, pioneer in the 1930s to 1950s of a revolutionary method for treating polio, was one of these. ${ }^{18}$ Thus many feminists of the $1960 \mathrm{~s}$ and 1970s promoted nurturing and co-operation as being as valuable as assertiveness and independence.

Contributing to this more traditional strain were strongly conservative, politically influential lobby groups like the Society for the Protection of the Unborn Child. These and the Contraception, Sterilisation, and Abortion Act passed in 1977 provided challenges to feminists of the "New Woman" type. The physician Diana Mason fought for the rights of the unborn child, thus echoing the Mazengarb Report's anti-abortion stance and concern with unmarried mothers and teenage pregnancies. Similarly, moralist and former nun, Patricia Bartlett who urged greater censorship in the fight against pornography, reflected the Report's censorious attitudes.

Perhaps the campaign for homosexual law reform in the 1980s caused Gee to recall the oppression of homosexuals in the 1950s and the discriminatory Report. (The Crimes Act of 1908 had criminalised homosexuality between men, as Michael King has stated in relation to writers Frank Sargeson, and Bill Pearson. It also failed to acknowledge even the possibility of female homosexuality. ${ }^{19}$ ) Fran Wilde's Homosexual Law Reform Act in 1986 contributed to a more liberal climate within which Julie 
Glamuzina and Alison Laurie documented the Parker and Hulme story in Parker \& Hulme: A Lesbian View (published in 1991). Similarly, Peter Jackson made a movie of the story. Entitled Heavenly Creatures, it screened in New Zealand cinemas in 1994. A keen reader and moviegoer, Gee would have been re-acquainted with the infamous murder of 1954.

In summary, then, women's roles of the 1990s could be divided into three broad categories: the liberal feminist (including gay women), the mother or nurturer, and the moralist.

\section{The Novel}

In writing Hostel Girl Gee looks back from the 1990s and a quite self-consciously liberal period to explore the more conservative 1950s and a confusing social climate. In chapter one Ailsa reflects this confusion. She considers Truth's "scare stories about immorality among teenagers in Naenae, up the valley - sex parties, nudity, illegitimate babies" (p. 8), and the Parker and Hulme case: "Those girls in Christchurch had killed one of their mothers with a brick" (p. 21). But she also recalls the moralistic Report: "The government [had] ordered an enquiry and published the resulting Mazengarb Report calling for more religious teaching and higher moral standards" (p. 8).

Gee sets contemporary history's diverse roles within this period of conflict. As the future feminist, Ailsa is working class, physically strong, and assertive, as her thoughts suggest in chapter one: "You had to make some noise if you wanted to be heard and you had to go after things and not hang back" (p. 7). Out of kilter with the conservative Willowbank School she attends, she has been told: "Tone yourself down, young lady" (p. 7). In Ailsa, then, Gee seems to conflate traits characterising New Zealand's twentieth-century feminists, but he also makes Ailsa believable within the conservative times in which she lives.

Effectively occupying a feminised role, Errol seems to be a version of the artist, perhaps as author and possible homosexual. In a childless marriage, he is mannered, tidy, and effeminate. Recalling Frank Sargeson and Bill Pearson - writers whose homosexuality was suppressed by its illegality in the fifties - Errol has a "voice", quotes literature incessantly, and has written and performed in plays. Along with his sexuality, his artistic expression is limited by the period's conformity.

Gloria seems to fill the role of the sexually active female and is older and more sophisticated than Ailsa. Ailsa observes upon meeting her: "[Gloria] looked, leaning back smoking, like a woman who'd been places and done things and knew about money 
and the world" (p. 21). But like Ailsa, Gloria does not fit with the conservative times. She demonstrates what the Mazengarb Report termed "sexual laxity", has pre-marital sex, and becomes pregnant. Ailsa's secrecy in considering a means of abortion, and Mrs Nimmo's nervousness when Ailsa consults her are reminders that in 1955 abortion was illegal. Moreover, like Bartlett, Gloria is Catholic and believes abortion is immoral.

Through depicting mothers with different roles to their daughters, Gee complicates the picture. Ailsa's mother resembles the nineties' feminist caregivers who combined strength and independence with nurturing and a conservative morality. A war widow, she depends on a benefit, and supplements her income by running a hostel and working in the Griffins factory. As a mother, and the hostel's matron, she also nurtures the dental nurse trainees. Furthermore, recalling the Mazengarb Report (which blamed sexual licentiousness on co-educational schooling), she withdraws Ailsa from the co-educational state school Hutt Valley High, and sends her to the private single sex school Willowbank. Although independently minded, Ailsa is influenced by her mother, and becomes more moralistic and nurturing as Gloria's protector.

On the other hand, Gloria's mother has been abused by her husband. With no recourse to the refuge or rape crisis centres, or welfare benefits of the 1970s to 1990s, she has stayed with him. As nurturer and victim she influences Gloria who, although sophisticated and bold, in training for the exclusively female career of dental nurse, is actually a nurturer herself. Having been beaten by her father, and submissive to the dominating male, the unmarried Gloria believes she is pregnant in an era with little available contraception, and is thus also a victim

Different again, Mrs Page seems to typify the wife of the successful fifties' male. Puritanical, pretentious, and obsessed with appearances, she scorns hostel life which she sees as depraved, and continually washes her hands as if to keep herself morally clean. Occupying the traditional role of home keeper and socialite, she influences her daughter Helen, who is "boy-mad" (p. 10).

In the range and mixture of female roles, Gee reveals his interest in diverse parts and shows Ailsa to be subject to these influences. In Hostel Girl he explores the New Zealand female psyche and its conflict between heterosexuality and homosexuality; and independence, motherhood, and morality.

\section{5 - Social Divisions}

1955 was indeed a conservative period. Following the end of World War II, many lived in dread of war, particularly nuclear war, and had, it has been argued, an overwhelming 
need for security in terms of possessions, attitudes and beliefs. ${ }^{20}$ Few women occupied recognised positions in politics or the arts and, with the swing to conservatism, were forced more than ever into the traditional roles of wife, mother, and guardian of the home. Indeed, as Gordon McLauchlan has noted, New Zealanders generally favoured early marriage and "the conjugal (nuclear) family". ${ }^{21}$ They dreamed of owning a home, modern appliances, and a car, and of employment with the government who through the welfare system and superannuation would look after them throughout their lives.

However, although conservative, the period was also divided. Within New Zealand's supposedly egalitarian society the family took two broad forms. First, there were those suffering hardship. Migration to the cities and housing shortages saw a huge increase in state housing, particularly in the Hutt Valley. But with the boom in the Hutt Valley's population, eastern suburbs like Naenae, which were predominantly working class areas, became what has been described as "weatherboard ghettos where rows of identical houses were jammed together in the middle of paddocks". Despite the prevailing ideal of the domestically oriented mother, many mothers had to work to supplement their husbands' incomes. Single mothers maintaining broken homes earned the family's sole income. Indeed, the Hutt Valley Youth Survey found that overall in Petone a third of the children visited had mothers working in local factories. ${ }^{22}$

Second, more affluent families of white-collar workers such as doctors, lawyers, and senior public servants benefited from better times and typically lived in suburbs such as the Western Hutt Valley. With a right wing government in power National politicians like Jack Marshall and Keith Holyoake (who both became Prime Ministers) modelled the conservative, middle class family life. According to Fraser McDonald, in such suburbs the wife was "the curator of the small museum of her husband's artefacts and houses, cleaning and oiling, maintaining spotless levels of housekeeping". ${ }^{23}$ In these families, roles were clearly defined - father was breadwinner and mother was housewife or socialite.

\section{The Novel}

Living in the aftermath of World War II and under the shadow of the bomb, Gee's characters, like their real counterparts, look for safety and security to traditional mainly British codes, the nuclear family, uniformity, and materialism. However, there are sharp divisions between the "have-nots" and the "haves" which, with "the shining rails that cut the Hutt Valley into halves" (p. 6), are associated with the valley's eastern and western sides. 
True to life, those living in the fictional Eastern Hutt Valley are mainly working class and occupy high density housing, and experience post-war hardship and altered family structures. Ailsa's father, born in working class Glasgow, has been a boilermaker, then served and was killed in Crete during the war. Like her historical counterparts, Ailsa's mother, a war widow on a minimal benefit, is forced to work as hostel matron in exchange for accommodation, and she also works in the local Griffins factory.

Recalling the real Western Hutt Valley, the fictional Western Hutt is populated by upper middle class characters, including white-collar workers who lead affluent lifestyles. The Pages typify the families of this materialist world. Mr Page is a lawyer in the family firm of Page-Endacott whilst Mrs Page has never worked. Ailsa notes that the Pages have "a house in which there might be a housekeeper or a maid (p. 10). Recalling Fraser McDonald's "small museum of [ . . ] artefacts", the Pages' lounge has "fat frilly chairs" and is full of "thingy things [ . . ]: porcelain figures and wired-up plates that were neither beautiful nor useful” (p. 31). Mr Page fills his leisure time by cleaning his car; Mrs Page has her own car, entertains, takes trips into town or participates in amateur theatricals.

The middle class inhabitants of the Western Hutt Valley are also recalled in the Parkinsons. Errol Parkinson is a senior civil servant who travels to his government job every day on the unit. He has an expensive British car - a Wolsey - spends leisure time in his garden with its mown lawns and "neatly raked soil" (p. 37), and participates in amateur theatricals. Gee therefore extends the depiction of divided female roles by carefully reconstructing the divided society of 1955.

However, in exploring divided parts, Gee skews the novel's documentary value. He takes Elbe's Milkbar (frequented by working class teenagers) from High Street in the Western Hutt Valley, and re-locates it next to the Prince Edward Theatre in the Eastern Hutt Valley. Furthermore, whilst characters are divided from each other in socioeconomic terms, they are nevertheless aware of how the other half lives. Ailsa and her mother aspire to ownership of "a little house in Wellington, halfway up a hill" (p. 7) whilst the middle classes (Helen, Calum, and Errol) are fascinated with the perceived lower morality of hostel life. Poised between childhood and adulthood, contrasting female roles, and a divided society, Ailsa herself is split, as her position on the overbridge suggests:

Sometimes [Ailsa] imagined that [the overbridge] existed outside the world. She went down from it, one way or the other, into places where her life was tangled, where too much trying was asked of her. She liked to linger on the bridge and look up and down the shining rails that cut the Hutt Valley into halves, and in a way cut her life in half. (p. 6) 
Whilst grounding Hostel Girl in reality and accurately documenting fact, Gee emphasises conflicts that are mental, geographical and social, and reflects these in microcosm in Ailsa.

\section{5 - Cultural Divisions}

In Hostel Girl culture is as divided as society. Following World War II and the Cold War there was a worldwide explosion of American popular culture in New Zealand. But there were also feelings of fear which led to a "stultifying blanket of conformity" as society fell back on the Victorian legacy inherited from Great Britain. ${ }^{24}$

Reacting against war, and post-war conformity (including ideals of formal engagement, marriage, and the nuclear family), the American movie industry redefined femininity, sexuality and adolescence. Movie stars like Marilyn Monroe brought an overt sexuality to the screen. Indeed, conducting a narcissistic love affair with the camera, she treated men as playthings to be acquired and discarded at will, and exhibited an emancipated amorality that was copied worldwide by teenagers and young women. Hollywood movies also challenged the stereotypical roles of male teenagers and initiated a youth rebellion. Rejecting the adult world, the British urban working class Teddy boys became a cult. Adopting thigh-length Edwardian-style jackets, they pursued gang warfare in streets and dance halls. Taking on a more sinister slant in the States, gangs wore black leather brass-studded jackets and rode motor bikes. Two Hollywood stars became iconic: In Hollywood's The Wild One (1954), which depicted gang warfare, the victor Marlon Brando was surly, sneering, and leather-clad. And in Rebel Without a Cause (1955) James Dean, the victim, was a vulnerable, moody, delinquent boy, misunderstood by adults. Also, of course, 1955 saw the explosion of rock 'n roll, and the song 'Rock Around The Clock' was made into a movie by the end of the year. With its compulsive beat, rock 'n roll fast became popular amongst youth whilst Elvis Presley, the "King" of rock ' $n$ ' roll, was the first white singer to sing about lust. Worldwide, working class teenagers fell in love with him.

However, the model queens of magazine covers stood for propriety. The English Barbara Goalen, attired in hat, long gloves, and diamonds or pearls, posed as a "lady". Movie star Grace Kelly was "every inch a lady on the screen" and actually married a prince to become "every inch a princess", whilst Shakespearean actress Claire Bloom had a "look of cool composure and high caste". Typically willowy, graceful, and with high cheek-bones, these stars implicitly promoted the class system and effectively held court in their homes. They were matched in music by the reassuring sentimental conformity of ballads by gentlemen crooners like Vic Damone and Bing Crosby. ${ }^{25}$ 


\section{The Novel}

In Hostel Girl Gee creates a realistic picture of cultural and moral conflict in 1950s' New Zealand and its relationship to the Hutt Valley's geographical and social divisions. Within the fictional Eastern Hutt Valley's mainly working class population, the hostel girls are strongly influenced by the American teenage subculture. Like the real Hutt Valley's teenagers, Ailsa and Gloria frequent the streets, picture theatre, Hutt riverbank, Petone waterfront, and Elbe's milkbar. Ailsa sees Gloria with her make-up and provocative clothing in terms of Hollywood movie stars. In chapter one she has "a profile that [is] pretty and pointy [...] and lips that [are] pouty and discontented, kissy lips [and] looks like that actress, Ann Blyth" (p. 20). Recalling the real "blonde bombshell", Marilyn Monroe, Gloria seems to Ailsa to have been "a bombshell in Stratford" (p. 21). She walks "with a rat-tat of high heels" (p. 24), reproduces "an actressy walk" (p. 25) and drops "her cigarette on the footpath and [stands] on it" whilst freshening her lipstick in case she meets "Mr Right" (p. 24). Gloria adds to Ailsa's view of her as a version of a screen goddess, commenting from the Woburn overbridge in chapter two: "We're up here like the pictures. We should put on a show" (p. 28). Ailsa, therefore, imagines Gloria practises the sexual freedom typifying Hollywood stars and that she is "a good time girl" (pp. 98-99). Calum on the other hand recalls James Dean. In chapter one he has "a sneery little smile [and is] bent in his face, which [makes] him ugly and good-looking at once" (p. 13). An outcast who rebels against his parents, he tells Ailsa in chapter three: "I'm the Page that got ripped out. [ . . ] I don't care about them. I do what I like" whilst Ailsa guesses that he gives his parents "a hard time" (p. 36).

Gee matches the depiction of popular culture with the depiction of traditional English culture. Those living in the Western Hutt Valley, particularly the older generation, conform to its values and class system. Mrs Page treats Ailsa as inferior because she is physically well developed and working class, and reportedly describes her as "straight out of the Mazengarb Report" (p. 109). The studied elegance of Claire Bloom and Grace Kelly is recalled in Mrs Page. "A tall woman with an elegant face", she is "willowy" (p. 11), and bends "her long neck" in a ladylike way (p. 112). Similarly, in chapter five Willowbank's girls seem like "little misses trying to be Claire Bloom" (p. 59). The era's sentimental music sung by Vic Damone and Bing Crosby would be enjoyed by this conservative generation. Indeed, as the mysterious letter writer Errol sends Gloria a note quoting the Crosby song: "You are my heart's desire” (p. 58). 


\section{5 - Moral Chaos Versus Moral Forces}

Falling in love with American culture, New Zealand teenagers became actors in their real life versions of American movies. Female teenagers known as "huntresses" modelled themselves on Marilyn Monroe and roamed the streets or flocked to beauty parlours for make-up and platinum hair. Male teens adopted Brando's swagger and sullenness and became "wild ones". Forming motorbike gangs, upsetting the suburbs, and frequenting milkbars such as Elbe's in the Hutt Valley, they were known as "milkbar cowboys", or they imitated James Dean's troubled moodiness and his dissatisfaction with adults and conformity. ${ }^{26}$

Rock 'n roll featured on radio, film, and jukeboxes in milkbars to which motorcycle gangs like the Hutt Valley milkbar cowboys flocked. Widely regarded as delinquents, they were inspired by The Wild One, and the hit "Black Leather Jacket and Motorcycle Boots". According to Yska, in Auckland's Queen Street in 1955 a throttle happy group named the Curries' Cowboys (after Curries' Milkbar) “tangled” with traffic officers and thundered up and down the street sporting female passengers dubbed "pillion pussies" on their bikes. Even more synonymous with juvenile delinquency were the bodgies and their female counterparts - the widgies. Frequently the gangs clashed in major fights or "rumbles". ${ }^{27}$

Accompanying the influx of popular mass culture was an increase in juvenile delinquency, particularly in state housing areas like the Hutt Valley. In 1953 a high rate of adolescent offences in Naenae and other eastern suburbs led to inquiries by forty state, local body, and voluntary agencies. In the same year seven girls and eleven boys between twelve to sixteen years appeared in court on sixty-one charges. The Hutt Valley's juvenile crime rates were double the national average, with many cases of sexual promiscuity. Low-brow and sensationalist, Truth blamed selfish parents, including working mothers. Yska documents a mid 1954 Hutt Valley sex scandal, involving fortyone boys and sixteen girls, many of them attending co-educational schools like Hutt Valley High, and participating in ninety offences of "carnal knowledge" (or underage sex) and indecent assault. ${ }^{28}$ Also worrying was the perception that "seduction [of teenage girls was] from older men rather than young lads in the first instance [and that] when they [were] seduced by the older men they [would] go on to corrupt the younger boys". Miss J. Scotter, Principal of the Burwood Girls' Training Centre for delinquent girls, commented: "I would think that a lot of girls have been interfered with in their own homes by their brothers or fathers". ${ }^{29}$ 
Even more serious were murders involving adolescent killers, many thought to have resulted from living in a "movie-soaked dreamworld". These included what Truth termed the "milk bar murder" which occurred in Somervell's Milkbar, Queen Street, Auckland in March 1955. It involved teenagers Sharon Skiffington and a mentally ill British immigrant worker, Frederick Foster. Foster was convicted of murder after being rejected by Skiffington and shooting her in the face. Nineteen days later another murder involving bodgies occurred in a Queen Street café. Following a "rumble" over a sixteen-year-old brunette, nineteen-year-old Albert Black fatally stabbed Alan Jacques. The third of the murders occurred in Whangarei, also in 1955, when a mentally unstable Maori labourer, Eddie Te Whiu, murdered an elderly widow when caught robbing her house. $^{30}$ However, it was the aforementioned Parker and Hulme case that most shocked New Zealand.

Stanley Cohen's examination of mods and rockers in the United Kingdom in terms of "actors" and "audience" is relevant to this New Zealand context for, rather than actors in the fifties' dramas, a contingent of moralists became an audience whose zeal was justified. ${ }^{31}$ However, their exaggerated reactions helped create the moral panic they fed off. For example, responding to sex and property offences in the Hutt, the Hutt Valley Youth Survey concluded that the "destabilizing social effects of rapid urban growth - broken homes and de facto parents, heavy drinkers, working mothers and neglected child rearing" were to blame, especially in the new state house areas. ${ }^{32}$

Petone's Senior Sergeant Frank Le Fort saw his role as preventing adolescents from using condoms. On 6 July 1954 he was quoted in the Dominion as reporting a "shocking degree of immoral conduct which spread into sexual orgies perpetuated in private homes during the absence of parents, and in several second-rate Hutt Valley theatres", according to Yska. Indeed, Yska describes him as "a veteran of the Imperial Army [and] a cold-water puritan in the Baden-Powell mould". ${ }^{33}$ Apparently Le Fort patrolled local picture theatres and grilled dozens from the Elbe's Milkbar Gang over the missing schoolgirl case in the hope of eliminating vice from the valley.

Of course, the release of the Mazengarb Report contributed to this moralistic trend, and the increased book, film, and radio censorship proved what a sweeping mandate politicians and police had been given. In 1955 New Justice Minister and Attorney General Jack Marshall, teachers and middle class intellectuals crusaded against American slang and lowbrow themes, and looked to Britain for cultural sustenance. Film censor Gordon Mirams saw Hollywood as embodying a new, looser morality. Rejecting The Wild One and Rebel Without a Cause, he, like Marshall and others, promoted 
marriage, the nuclear family, and traditional values associated with Great Britain. ${ }^{34}$ What was "bad" then, was seen as a function of Americanization.

Most archaic of moralistic measures was capital punishment, reintroduced by the National Government in 1950. Pauline Engel has described Jack Marshall as "the Holland Cabinet's most zealous supporter of the death penalty". According to Foster's defence counsel Martyn Finlay, Marshall gained political mileage when, faced with Foster's mother's plea to spare her son's life, he decided to let Foster hang on 7 July. In spite of numerous petitions and appeals, Te Whiu and Black were also finally hanged, making a total of three hangings in $1955 .^{35}$

In 1958 Auckland psychologist A. E. Manning wrote what Roy Shuker has described as an "openly hostile" study of Bodgies. Manning's report, The Bodgie: A Study in Abnormal Psychology, described interviews with thirty Australian and New Zealand teenagers and drew on psychoanalysis, clinical reports and historical data to conclude that bodgies were "abnormal" and "social 'boils' on the body of a tense and emotional society". ${ }^{36}$ The report prescribed psychiatric treatment as a solution. In 1958 Keith Holyoake (leader of the opposition) similarly urged that hooligans be sent to correction camps. The opinions of Marshall, Manning, and Holyoake represented a middle-class conservative society who were completely unable to comprehend youth, the underprivileged, the unstable, and a class and culture different to their own.

\section{The Novel}

Along with the cultural clash, Gee depicts conflicting morals. These too are associated with the Hutt Valley's two sides. In chapter one Ailsa remembers her first year (1954) at Hutt Valley High and perhaps the ninety cases of carnal knowledge and indecent assault associated with that and other co-educational state schools in the Eastern Hutt Valley in 1954. In her second year of high school (now at Willowbank in 1955), she refers to the previous year as "the sex scandal year" (p. 8). Apparently influenced by these scandals, Mrs McGowan worries about "schoolboys and schoolgirls having sex among the gravestones in the cemetery" (p. 8). Beaten by her father, Gloria recalls Scotter's view that teenage girls, abused by brothers or fathers, went on to corrupt adolescent men.

Gee alludes to many scenes where scandalous sexual escapades historically took place - the Petone waterfront, Hutt riverbank (p. 111), the Wainouiomata hills and the Prince Edward Cinema (p. 24). Like the historical Elbe's, Elbe's milkbar in chapter nine is "full of bodgies and widgies in leather jackets and short skirts" (p. 111). Through Ailsa's recollections of sexual escapades and the Parker and Hulme case (p. 8) Gee therefore suggests the extent to which (thanks to Truth) moral panic permeated people's lives. 
The emphasis on moral chaos in the Eastern Hutt Valley is balanced by an emphasis on the Western Hutt Valley's moral forces. Ailsa remembers the Mazengarb Report with its call for "more religious teaching and higher moral standards" (p. 8). Mazengarb actually lived in the Western Hutt Valley. His Victorian morality and that of policeman Frank le Fort, and crusaders Marshall, Mirams, and Holyoake are typified in Mrs Page and Errol Parkinson, who are also Anglo-Saxon, middle-class citizens with strong religious and moral codes and highbrow perspectives. Willowbank School reflects these values and Ailsa has to attend its classes in religious study or "Divinity" (p. 9).

However, Gee suggests the Hutt Valley's two sides are as culturally and morally mixed as they are geographically and socially. Thus, in the Eastern Hutt Valley, with its predominantly American popular culture, exist elements of traditional culture. For instance, the very name "Prince Edward" suggests not only the picture theatre, but also British sovereignty, whilst Cambridge Terrace on the railway line's eastern side, like Oxford Terrace on the west, recalls an English university town. Names like Waterloo and Stratford play into Gee's hands since they evoke England. Furthermore, the religion, class arrogance, and moral conservatism that more often characterise Willowbank, the Pages and Parkinsons, exist within the teeming hostel society. The hostel is run by the YWCA (the Young Woman's Christian Association) and thus has a religious basis. One hostel girl, Betty Briggs, is strongly religious, and Gloria herself is Catholic and fears "mortal sin". As she tells Ailsa in chapter two, she is morally conservative and known as "Gloria Woodn't" (p. 28). Moreover, Mrs McGowan describes some hostel girls as "stuck up little misses" (p. 6). Ironically, Ailsa and her mother are no exception. Ailsa views the hostel as being on "the wrong side of the tracks" (p. 8) and likes the Page family for its wealth, whilst her wish to shift to Wellington is partly to escape the common life of "grinny nurses, shrieking nurses, crying nurses" (p. 7).

Similarly, the Western Hutt Valley is the location of Hutt Valley High School and Hutt Recreation Ground - a common ground where contact sports are played. Moreover, the private school Willowbank has on its staff Mrs Nimmo, whose position as "social studies teacher" seems emblematic of her socialist/communist beliefs. Indeed, she talks about "the evils of capitalism [and] the humbug of religion" (pp. 8-9), and teaches Ailsa about people "in different lands" and workers who "plant rice in a paddy field" (p. 65). Furthermore, Willowbank girls read about sex scandals in Truth, and swear. Contradictions also exist within the conservative Page family. Mr Page is "thoroughly imperfect, with his fat ears and blotchy cheeks" (p. 113), Helen is eager to hear "everything Ailsa [says] about the hostels" (p. 10), and Calum has had the supposedly working class disease of polio, and befriends Ailsa who lives on the other side of the track. 


\section{The Deeper Influence of Culture}

Ailsa is as strongly influenced by fictional stories as she is by real ones. In chapter four, overhearing hostel girls discussing "dreamy" (p. 46) kisses in the movie Brigadoon (which depicts the relationship between two sisters and two young men) she projects this romantic view onto Calum: "She thought that if he wanted to she would let him kiss her. She hoped he would" (p. 47). ${ }^{37}$ Ailsa does the same to Gloria and Bevan when she sees their "two heads in the car joined together - a long kiss" (p. 47).

Gee counterpoints the romantic Brigadoon by alluding to Mildred Pierce - a movie with a more sombre view of sisterhood. ${ }^{38}$ In chapter two Ailsa sees herself and Gloria in terms of Mildred Pierce: "[Gloria] looked like that actress Ann Blyth, who had been the selfish daughter in Mildred Pierce. Ailsa felt like the plain daughter who had died" (p. 20). A little later, apparently recalling the movie's murder, Ailsa projects it onto Gloria. Indeed, Gloria's wish that her father were dead, the Parker and Hulme murder, and the murder in Mildred Pierce seem to become confused in Ailsa's mind: "How could anyone want their father dead (although those girls in Christchurch had killed one of their mothers with a brick)? [Ailsa] seemed to look through a door into another room and glimpse Gloria acting strangely, like a woman in a murder movie doing furtive things" (p. 21).

Gee builds upon Ailsa's consciousness of Mildred Pierce by integrating features of it into the novel. Directed by Michael Curtiz in 1945, it typifies the noir genre in that it is black and white, naturalistic, and depicts everyday characters beset with difficulties in a thriller context. Usually with post-Cold War settings, films noirs reflect the era's fear and moral corruption. Characterised by hard-boiled villains or anti-heroes who are sardonic insecure loners, films noirs also include the loving, trustworthy woman, and the duplicitous, tough-sweet femme fatale. Often detective thrillers involving betrayal and murder, noir films are set in an underworld of corruption and crime. Convoluted plots, maze-like sets, expressionist lighting, skewed camera angles, urban night scenes, shadows and dark alleys contribute to the distorted scene. ${ }^{39}$

Like Mildred Pierce, Hostel Girl is atmospherically bleak (its alienated characters include Ailsa who feels lonely on the overbridge, Gloria who sits alone on the train, and Calum, isolated by disease). Fear dominates, whilst Errol represents the villain, Calum is the sardonic lonely anti-hero, Ailsa is the trustworthy loving female, and Gloria is the beautiful, tough yet child-like femme fatale. Becoming entangled with the mysterious bike-rider and letter-writer and, at the end of the novel, a killing, Ailsa plays detective. 
She pursues the predatory biker through a maze of shadowy streets, and perceives a nasty reality.

Parallels exist between Gee's characters and those in the movie. Mildred is a strong-willed single mother who acquires menial employment to restore her family to security and provide a private school education and material privileges for Veda, the older daughter. The spoilt Veda develops social ambitions, marries upwards, uses pregnancy to blackmail her husband's wealthy family, and has an affair with her mother's second husband, Monty Barogen, an unscrupulous playboy, whom she kills. Like Mildred, Ailsa's mother struggles to provide privileges and a private school education for her daughter whilst Ailsa, like Veda, has social ambitions in that she believes she lives on "the wrong side of the tracks" (p. 6). Comparing herself to "the plain daughter" (p. 20) - the more likeable, tomboyish younger sister Kay - Ailsa fails to realise that the older pregnant Veda may be recalled in the pregnant Gloria, both of whom have had dubious relationships with father figures. Gee thus contextualises Ailsa's experiences whilst suggesting her romantic perceptions.

Much as Ailsa's reflections and actions recall Mildred Pierce, Errol Parkinson's speech and actions reflect a rather different culture. In chapter three, he speaks in a "radio voice" (in echo of the BBC), poses "like in a play" (p. 38), and thinks "he's in a movie [and] as in command, as a movie hero - Errol Flynn" (pp. 39-40). (Ironically his name conflates Errol Flynn the swashbuckling hero, and Pauline Parker the murderess.) Attired as a gentleman, cigarette and glass in hand, lounging in a wicker chair, he resembles the archetypal Englishman of a drama by Noel Coward or Oscar Wilde. (In chapter five Ailsa alludes to Wilde's The Importance of Being Earnest which anticipates Hostel Girl in depicting confused relationships between two females and males.)

As Calum and Ailsa note in chapter four, the hostel's peeping tom has a "voice [...] kind of like that actor, upper class. [... ] George Sanders" (p. 55). Although not mentioned in direct conjunction with Errol, it seems likely that the prowler is Errol and that he models himself on Sanders. A Hollywood actor, Sanders was reputedly "all style and no sincerity [and] all mind and body - no spirit" whilst his voice was once described as "silky, insinuating, impeccable [with] languid Oxford cadences reflecting a malice so well-bred, a lasciviousness so refined". ${ }^{40}$ All role-play, manner, and voice, physically large yet lacking the soul he seeks through Gloria, Errol certainly recalls Sanders.

As the anonymous letter writer, Errol also draws on Shakespeare's "Song for Sylvia" from Two Gentlemen of Verona to ask: "Who is Gloria? What is she?" In correcting the allusion, Mrs Nimmo states in chapter four: "It's Sylvia, not Gloria" (p. 58). Errol's appropriation of Shakespeare's play fuses with Gee's. Thus Shakespeare's 
two sets of opposed couples (Proteus and Julia, and Valentine and Sylvia), who represent the impure and earthly versus the pure and spiritual, are recalled in Errol and Ailsa who in different ways pursue purity, and Calum and Gloria who are more sensual. Proteus's epistolary courtship of Sylvia is echoed in Errol's wooing of Gloria by letter. Elevating Sylvia to a celestial level, Proteus describes her in Act IV, Scene ii as "too fair, too true, too holy," whilst other swains ask: "Who is Sylvia? What is she,/That all our swains commend her?" ${ }^{41}$ In quoting the song, Errol certainly seems to see Gloria as mysterious and pure.

In chapter six Calum remembers a play Errol has written in which "there was this guy who loved this girl. She was supposed to be too good for him. Poor, you know, but sort of superior. Pure and spouting poetry and stuff. And this poor dope kept writing notes to her. [...] Blue for her name - it was Dorothea or something - and red for being in love with her and black for sad" (p. 80). Given that the play's heroine is named Dorothea, it seems likely that Errol may have used George Eliot's Middlemarch as its source. ${ }^{42}$ Where Eliot's elderly Casaubon wooed the youthful Dorothea through his letters, the elderly Errol woos Gloria in a similar manner. But the idealistic, independently minded Dorothea - a forerunner of the twentieth-century socialist feminist - is more closely recalled in Ailsa.

In summary, real and fictional stories (and probably Margaretha's diary) commonly depict a range of female roles (from pure, to independently minded, to fallen), and also sisterhoods, and intergenerational relationships (between mothers and daughters, and father figures and adolescent females). By fusing these Gee contextualises the novel's characters and events. But as actants, actively contributing to the parallels established by Gee, Ailsa and Errol become products of the stories they have absorbed and projected on others. They are, therefore, partly responsible for characters' different roles and fates. Ailsa is the transcendent hero, Calum is the fallen (anti) hero, Errol is the persona/villain, and Gloria (desired by the other three) represents the victim or soul. At the same time, these roles form a symmetry that can be differently divided. Thus the Eastern Hutt Valley's two working class females (Ailsa who is a moral force, and Gloria who contributes to moral chaos) are balanced against the Western Hutt Valley's two middle class males (Calum who contributes to moral chaos, and Errol whose concern with purity makes him superficially a moral force). Whilst individual characters are incomplete, the four together are emblematic of the whole. And Ailsa (in whom stories from each side of the Valley fuse), reflects the four collectively as well as the whole divided Hutt Valley and New Zealand psyche. 


\section{Ailsa as Audience and Actor}

Preferring to be audience rather than actor, Ailsa in travelling west projects popular culture and her fears of moral chaos onto the Pages and Parkinsons. In chapter four she sees Mrs Page as though in a movie: "Mrs Page [... ] gave her almost non-existent smile, one hand drifting smoke and the other cupping her elbow. Women at windows stood like that in Hollywood films" (p. 50). Mr Page causes her to feel "manoeuvred" and to think that he "could easily be the one who had watched from under the tree" (p. 31). Unexpectedly inviting Ailsa again to practise tennis, Helen gives a "nasty" laugh and comments that Calum "might as well start with you" (p. 30). Underlying the Pages' friendship, then, may be a concern with finding Calum a sexual partner. Certainly, in chapter three the Pages' place seems to be a stage set for a drama in which, ironically, it is Ailsa who is the main actor to be watched.

In her view of Calum, Ailsa compensates for her fear of the potent father figure. Slim, disabled and weak where Ailsa is large, healthy and strong, he seems to pose little threat to her virginity. Stereotyping him as "crippled" (pp. 13, 34), noting his limp and "exaggerated lifting of his hip and a slapping down of his foot like a dinner plate", Ailsa feels "a small, contented glow [and that it is] a compliment that he would let her see him lying down" (p. 37). When asleep, it is his weakness that appeals: "She thought he looked weak, he looked pathetic, but that made a kind of stupid fondness grow in her" (p. 42). However, the tennis match is a metaphor for sexual encounter. Insistent that she serves to him, Calum throws balls at Ailsa, swivels her hips, demonstrates the grip on the racket, and seems to reveal an underlying potency. That he tells Ailsa he is training her to beat Helen at tennis suggests he seeks in her the physical power he lacks. Following the sexually charged match, Calum's invitation to "come in if you want" (p. 37) to the lounge and sofa hints at an interest in sex.

On the other hand, Errol who likes purity and "a touch of the ethereal [a] bit of soul" (p. 39), as he tells Ailsa in chapter three, is seen by her as a version of the evil father figure. As the sinister but relatively harmless biker in chapter two, he thus embodies Ailsa's fear of potent masculinity, the satanic, darkness and death: "His wheels made a ticking sound and the legs of his trousers went whish, like brushing dust" (p. 27). "His black hair gleamed in stray light passing though the leaves. He mounted his bicycle and pedalled along the footpath with his raincoat flapping round the rear wheel" (p. 29). Ailsa's reading of Dennis Wheatley's novels with their black magic, satanism, sadism, and torture, particularly of women, may also influence her view. Certainly her nightmare in chapter four recalls the horned, winged, horse-riding Satan on the cover of 
Dennis Wheatley's The Devil Rides Out: ${ }^{43}$ “As she drifted off to sleep [the bike rider's] glasses got shinier and took horn rims and his raincoat brushed the ground. It flapped like vulture wings when he mounted his bike and rode away" (pp. 49-50).

Ailsa's tennis match with the physically disabled Calum is set against her "match" with the mentally disabled Errol. Positioned on the boundary wall, Ailsa then experiences what could be regarded as an allegorical fall to experience. Jumping down into the garden she is confronted by Errol's almost human dog, with its black shoulders, yellow eyes, rubbery nose and large shiny teeth. Ailsa is used to "go[ing] after things and not hang[ing] back" (p. 7), and has claimed that "dogs, even Alsatians, didn't scare her" (p. 34). But now she seems to confront her animalistic side that is activated not only by Errol's dog, but also by the sensationalist stories she has heard, seen and read. Thus she demonstrates the fear that characterised others. Like Gloria in childhood she feels threatened by a father figure, like a beast she moans, like Calum she is paralysed, and like Errol in his butler role she has no voice:

\footnotetext{
A moaning sound came from her lips. The dog halted 10 feet away. Slowly, like a smile, it bared its teeth. Ailsa stopped the sound in her throat. [...]

The dog took up her noise, a rumbling sound. Its ears went flat. [ . . ] Its nose was like rubber, lifting off its teeth. She had not known teeth could be so large. They shone at the tips like a circular saw.

'Help me,' she tried to say, but no sound came. Who would help?

The dog took another step. Then it sank on to its stomach like a sheepdog, holding her; and every time she made the slightest move its lip curled back, showing its teeth. (pp. 37-38)
}

In addition, faced with Errol, Ailsa sees him as she has the dog in terms of a potent masculinity. Thus Errol's upper-class role-play gives way to a view of him as repulsively bestial: "Big-nosed, fat-mouthed and [showing] horsey teeth when he smiled [Errol's] mouth did not seem to have room for his tongue, or his elegant clothes for his fattish body" (p. 40). Ironically, Errol later does prove to be a threat, but not in the way Ailsa initially imagines. For, rather than the potent force that Ailsa supposes Errol to be, he at this stage may more closely resemble an impotent weakling than Calum.

The pairing of Ailsa and Calum, and Gloria and Errol is ironic, for they are mismatched. Ailsa has the virginal purity that Errol seems to see in Gloria, who has the sexuality that Calum desires in Ailsa. Similarly, Errol has the impotency that would allow Ailsa to remain virginal, whilst Calum has the sexual potency that is sought by Gloria. Gee thus establishes a symmetry that has the potential to change. 


\section{Cross-couplings and Shadow Worlds}

In crossing the railway-line characters in Hostel Girl do not always, metaphorically speaking, follow routes that are straight. Instead, through exchanging stories, they create tangled routes and encounter shadow worlds that increase the novel's resonance. In travelling from west to east Calum contradicts Ailsa's impression of him as crippled or weak, for he is able to move, stand straight, walk, play tennis, bike, dance, and feel passion. Living vicariously through Ailsa's strength and the possibility of her physical affection, he enters the hostel and her bedroom in chapter four, and sits on her bed. Ailsa as nurturer sees that Calum is "tired - perhaps in pain" (p. 55). Yet, despite his condition, Calum takes an avid interest in sensationalist matters - the peeping tom, Gloria's anonymous letter ("Gloria, you are my heart's desire", p. 56), and Gloria. He sees Gloria as "glamorous [...], a looker" (p. 56), acknowledges that he wants to sit close to her on the train (p. 86), and in chapter eight tells Ailsa he would have her "if old Errol doesn't want her any more" (p. 101). But Ailsa remains largely blind to Calum's interest in Gloria.

Calum's interest in Gloria may be reciprocated. In chapter five Gloria describes him as "not too bad" and adds that Ailsa should "hang on to him for a while, to practise with” (p. 63), ironically echoing Mrs Page's earlier remark. In chapter six (after Calum has refused Ailsa's offer to accompany him home) Gloria seems inordinately happy, as though involved in a new love affair, and tells Ailsa "I've had plenty of men chasing me" (p. 82). Thus the scene is set for a relationship between Gloria and Calum (that Gee develops further in Ellie and the Shadow Man).

In chapter five Errol as the mystery bike rider travels into the Eastern Hutt Valley. The episode which fuses the narrator's and Ailsa's points of view resembles a nightmare or sensationalist story, with features of film noir - an urban night, shadowy streets, amorphous shapes, and gleaming lights. The coat buckle seems optical, like a lens. Winking, as though conspiratorial, it appears to make Ailsa complicit in a dubious act: "[Ailsa saw] a passing gleam of light, like an eye opening then closing in the dark. [...] Something shapeless stood there - but it might be just a shrub, a part of the hedge. The gleam came again and went out; and suddenly she knew it was the buckle on the belt of someone's coat. [...] The buckle winked at her. A bike wheel gleamed. The shadow by the hedge became a man then slid back into something shapeless again. [ . . . ] His raincoat buckle glared like a wide-open eye" (pp. 66-67). Feeling cast as actor rather than audience, Ailsa fears being drawn into or penetrated by the biker's glaring light, whilst his coat recalls the vulture wings of her earlier dream. The psychic landscape thus 
embodies Ailsa's chaotic thoughts. It allows her to fill multiple roles - detective, Hollywood star, teen-age huntress, moral force, strident feminist, and fiercely protective nurturer: "The light seemed to link them like a string and she felt that he could run along it, agile as a monkey, and stand beside her in the shrubbery. [...] He flicked the wings of his coat over his knees and rode across Cambridge Terrace and up on the footpath opposite Ailsa's shrubbery” (p. 67). The satanic archetype apparently leads her towards death: "The street curved closer to the hills. She began to think that he was riding there; that a cave would open and he would vanish inside. She seemed to be in a gully where water should be flowing under her wheels. The man's reflector was like a torch angled backwards, leading her in" (p. 69).

Set to the east of the railway line and to the left of the novel's centre, the scene marks a turning point for Errol and Ailsa. Previously detached from Ailsa, Errol now seems drawn to her. Teasingly he whistles "Mairzy Doats" (p. 67), tracks her, and reveals his knowledge of her background. ${ }^{44}$ Ailsa is also strangely drawn to Errol in the battle over Gloria's soul. Indeed, Errol, as a demonic embodiment of Ailsa's shadow, increasingly possesses her and in chapter seven his image appears within the Eastern Hutt Valley's urban and domestic environments: “Ordinary things began to seem too ordinary, as though hiding something dangerous. Errol Parkinson might step out at any moment from behind a lamppost or a tree, or Ailsa might see him in the mirror, sitting on the edge of a bath while she brushed her teeth" (p. 85).

However, in chapter eight when Ailsa enters Errol's house, she confronts an art world that reveals a different Errol - one who yearns for order, purity, and transcendence as opposed to the animalistic side she has imagined. In this world he has performed a traditionally female role - the kitchen is polished with everything in its "proper place" (p. 102). As Calum says, Errol is "a neat guy [ . . . . He does the housework, not his wife. The cooking too. He lends Mum recipe books" (p. 102). Separate bedrooms, single beds and "shirts, underclothes, handkerchiefs, with not a wrinkle in them even though his wife [is] in hospital" (p. 103), extend the picture of a marriage lacking physical affection, and a man who may be effeminate, impotent, and in search of purity.

On the sitting room walls the paintings of innocent, soulful maidens suggest Errol's real interest in youth and the spiritual. Seemingly they are by the pre-Raphaelite artists whose work included several versions of the Virgin Mary, The Lady of Shalott, and Ophelia (from Hamlet). As described by Queen Gertrude, Ophelia at her death holds a garland of "crow-flowers, nettles, daisies, and long purples", and falls into "the weeping brook. Her clothes spread wide/And mermaid-like, awhile [bearing] her up" (IV, vii, 169-176). ${ }^{45}$ 
Gertrude's words and the pre-Raphaelites' virginal Ophelias and Marys are recalled in Errol's pictures: "There were a dozen of them, all of young women with long hair and white robes, gazing into the sky or into pools of dark still water, holding wild flowers in their hands, dreaming on garden seats, standing by Grecian columns at the side of lakes" (p. 102). Ailsa and Calum recognise Ophelia. Calum's description of her "getting drowned. Except she's floating. She's got air trapped in her dress" (p. 102) recalls John Everett Millais's work of 1852. Best known of all paintings of Ophelia, it depicts her in death, wild flowers clasped in hands, dress billowing in the river. ${ }^{46}$

Witnessing Errol's return to the house following Madeleine's death, Ailsa sees his devastation as he again falls back on role-play. But rather than a pseudo Hamlet who loses someone innocent and pure, Errol adopts a maternal role as though Madeleine has been his child rather than wife. Thus he repeats the first line ("sweets to the sweet", p. 105) of Queen Gertrude’s eulogy to the dead Ophelia:

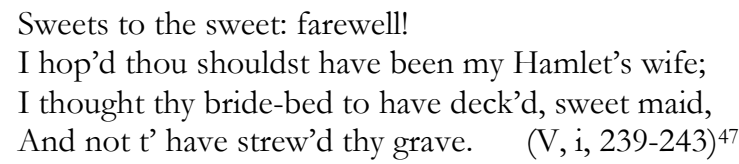

Ailsa does not recognise Errol's echo of Hamlet's madness and Gertrude's grief, or parallels between the painted virgins and herself. Bottom of her class in Divinity, Ailsa fails to realise that Errol's desire for Gloria, and for "angelic girls" (p. 107) and the "heavenly" is fundamentally similar to her own desire for transcendence.

Although living on different sides of the railway track, Ailsa and Errol have much in common. Ailsa's virginity is matched by Errol's obsession with purity, and each actively contributes to Gee's narrative. But where Errol is mentally unbalanced, an actor and man of words, with an interest in art, Ailsa is mentally immature, and an audience/artist concerned with the visual image, and with some interest in words. For Errol literature and art allow him to escape life, whereas for Ailsa art and literature are not yet understood within the context of life. Indeed, Ailsa sees art's surface and form but not its deeper universal significance. Different mixtures of the same parts, Errol and Ailsa seemingly equate to the two sides of the author/artist figure that comprises Gee.

\section{Merging Identities}

In sharing stories and worlds, the four protagonists exchange traits. Seen as a sexual predator, the older Errol, who mentally possesses Ailsa, reinforces a pattern of which Gloria's father and Gloria are a part. Moreover, Ailsa starts to occupy a larger place in 
Errol's thoughts, as Gloria did previously. Errol's aim through pursuing Gloria has been to deny mortality and death and, as he comments in chapter nine, he seems to see Ailsa as similar: "Ailsa, if I may say so [ . . . ] is someone who might conquer death" (p. 113).

Mrs Page's reported description of Ailsa as "a girl straight out of the Mazengarb Report" (p. 109) further suggests Ailsa's shift into Gloria's role and appearance as the "good time girl" that previously she saw Gloria to be. Indeed, Ailsa appropriates Gloria's lipstick, mascara, perfume, belt (p. 116), and sulky pout. Gloria recognises their similarity in chapter five when she offers Bevan to Ailsa: "You can take my place if you like. He's so dumb he'd hardly know the difference" (p. 63). Furthermore, it is when made up like Gloria that Ailsa becomes more attractive to Calum who tells her at the dance in chapter ten, "Hey, that's some eyes. You look great" (p. 120). Thus Ailsa resembles Gloria as she appeared in chapter two when she saw Gloria as resembling Veda in Mildred Pierce, and Ann Blythe who played Veda's part.

Appearing more natural, Gloria increasingly resembles Ailsa. Returning to the hostel in chapter eight, she seems "flushed and wind-blown and out-doorsy, not the least bit like a good time girl", and Ailsa notes: "Her Ann Blyth pout was gone. She looked rather prim” (pp. 98-99). Gloria's expanding physicality may be due to being unmarried and pregnant, like Veda from Mildred Pierce or the Naenae girls "up the valley" (p. 8). Indeed, Gloria qualifies her earlier story that "Bevan had tried to make me do it and I wouldn't" (p. 71) by saying: "But I did it once before. [ . . ] I had some stuff to drink. And it was warm in the car. So I thought, Why not?" (p. 91).

The identities of Errol and Calum also merge and change. Initially limp and "bendy" but drawn to Gloria, Calum becomes more mobile, stronger and potent, much as Errol appeared to Ailsa in his garden. In chapter nine, acknowledging himself as "the one from the Mazengarb Report", Calum reveals a continuing interest in Gloria by asking "Will she be at the dance?" (p. 110). Revolving between a rugby match at Hutt Rec, Elbe's milkbar, and the riverbank (p. 111) in quick succession, he seems to be seeking Gloria as did Errol previously and, when confronted with news of Gloria's pregnancy, echoes Errol's pallor (p. 115). In chapter ten, watching Gloria dance with another man (p. 121), he is keen to "go home" (p. 121). Biking round the streets in the final chapter, Calum seems as strong as the predatory biker.

Errol on the other hand appears to become as weak as Calum previously seemed. Ailsa has a hand in this progression. Having spied on and hunted Errol, she attacks him in chapter nine with images of femininity. By referring to Gloria's pregnancy, periods and methods of abortion, Ailsa destroys Errol's ideal of spiritual purity and tenuous grip 
on sanity. Her allusion to stilboestrol is particularly upsetting, perhaps because, as a (synthetic) female hormone, it is a threatening image of active femininity. ${ }^{48}$ Errol's reaction seems to suggest his fear on realistic and symbolic levels: "Errol Parkinson's cup rattled so hard [...]. Tea spilled in his lap. It burned him and he made a sharp sound, half yelp, half hiss. He put his cup down and pulled the cloth away from his skin. [ ... ] He could not control his eyes - they seemed to jump and rattle, as brittle as his cup (p. 115). Thus Errol moves spasmodically like the previously paralyzed Calum, moans dejectedly where earlier Ailsa moaned like a dog, and seems possessed by Ailsa where before Ailsa was possessed by him.

Ailsa becomes vengeful. Her obsession with Errol has, effectively, been a betrayal of Calum, and her revelation of pregnancy has been a betrayal of Gloria. In a sense Ailsa also betrays Errol for her projection of sensationalist stories onto him pushes him towards death. Like the fifties' moralists she contributes to the chaos she strives to conquer. With the entanglement of characters and stories from the Hutt Valley's opposed sides, Gee warns of the dangers of splitting antitheses as Errol and, to a lesser degree, Ailsa do, and suggests that fact, and literature and art should complement each other to provide a view that is more balanced or whole.

\section{The Hutt Valley Environment}

The conflicts of the 1950s are embedded in the environment. For example, in chapter one the natural landscape reflects moral chaos and Ailsa's thoughts about "sex parties, nudity, illegitimate babies" (p. 8). Thus personified, "fat bellied clouds" (p. 9) seem to suggest pregnancy, and forecast a shower and a birth. When the rain falls "cold and slippery and clean" (p. 15) it rejuvenates, and with drops "as large as bantam eggs" (p. 16) birth becomes almost explicit. However, water is also associated with Constable Frank le Fort's “cold water puritanism” (italics mine), and Mrs Page's fastidious washing of hands.

The urban environment also echoes the fifties' conflicts. The parallels of Oxford and Cambridge Terraces, the railway lines, and overhead wires in their very stasis and symmetry recall rigid moral forces. On the other hand, the overbridge which allows Ailsa to see further to "the three-storeyed buildings of Lower Hutt" (p. 24) represents the transcendent imagination, whilst the illegal barbed wired track comprises a route for those who, deviating from the norm, become emotionally scarred. In chapter two Gloria's comment, "I grew up with barbed wire”(p. 25), makes the metaphor explicit. 
A potent force, the train metaphorically transports different dream worlds between the Hutt Valley and Wellington, as Ailsa notes: “A unit passed, gathering speed out of Woburn station. People sat inside, some with their cheeks resting on the windows. [...] Each carriage made a separate world, pulled from Wellington to Upper Hutt" (p. 25). Recalling the cinematic imagination, it charges the urban environment with significance. Their dreams and stories having fused, the four main characters come together for the first time in chapter ten to enact parts in what resembles a Hollywood movie.

Here elements of film noir, projected by Ailsa onto Gloria, Errol, Calum and the landscape, fuse with Gee's application of the genre to the novel. Thus realistic characters are caught up in seemingly unreal events. The stark black and white lighting simultaneously suggests noir's documentary-style realism, melodrama, and the breakdown of norms. Calum's face is white (p. 120), Errol's car, suit and tie are black (pp. 122-123), and his schizophrenia is reflected in his "half white, half black" face (p. 126). "Black streaks" of mascara mark Gloria's face with fear and possible duplicity (p. 124), and fragmented images bespeak of reduction and death. But "the fuzz of light from the street lamp", Errol's silver hair, his "teeth [ . . ] a crescent, gleaming” (p. 123), people running with "jerky steps [... ], silver shoes glitter[ing] in the light" (p. 124), the shrieking wires, "shining rail" and hissing "invisible [unit's] swelling light" (p. 127) also distance the audience and perhaps cause it to see and think.

In its fusion of fiction and fact the setting includes shifts from simile into metaphor, and impression into action, much as movies now become part of the novel's real life. Although no longer acting, Errol is less normal than ever. With his previously suppressed shadow completely taking over his persona, he is effectively masculinised as the satanic predator Ailsa has earlier seen him to be. Taking up the onion knife, he threatens to penetrate Gloria as he never would have sexually when yearning after her soul.

Having merged, characters separate, and in crisis drop their masks to reveal the extent to which, paradoxically, they have become the roles projected onto them, or by them onto others. Where in chapter one Calum circled ineptly in his wheelchair and experienced the rain "as sudden as a car crash [making] a silver wall" (p. 15), it is Errol who circles in his car which he crashes into a real fence (p. 125). Previously it was Errol who was the powerful bike rider, but in chapter ten Calum strongly doubles Ailsa on his bike. Where standing on the overbridge in chapter two, Gloria seemed to be on the silver screen, she now falls through a car's real windscreen. And where in chapter one Ailsa felt that "the shining rails [. . ] cut her life in half" (p. 6), now with "the shining rails under his hands" (p. 127) it is Errol who is actually cut by the oncoming train. 


\section{Conclusion}

Returning in chapter ten to the railway line, which is where it began, the novel encloses Ailsa in a circular frame. Its interior and the Hutt Valley are crossed from north to south by parallel vertices: the mountain ranges on east and west sides, Cambridge and Oxford Terraces and, between them, the railway lines and overhead wires situated at the valley's centre. The Valley is also crossed horizontally from east to west by the Woburn Overbridge, the illegal track and characters' journeys and stories. Weaving through the regular warp, these tangled shadowy routes add texture to the interior.

Finally brought into focus are the novel's two most antithetical characters: Errol, effectively reduced to an infantile state, and Gloria's unborn infant who is barely embryonic. Each struggles for life - the former finally emblematic of the physical, the latter emblematic of the imagined. Never having met, the two are as bound together as everyone else. And at the end of the novel Ailsa and Calum effectively walk through its circular frame and into the future. Recalling Hollywood lovers, they clasp hands, but they are also accomplices in an imperfect world. The slanting rain may be a reminder that crooked routes and views, their own included, have contributed to others' deaths: "They went down the steps hand in hand. The rain slanted cold into their faces but she walked with Calum, at his pace, along to the tram" (p. 129). In spite of the balance Gee so masterfully achieves in this novel, characters' lack of personal balance ensures a continuing note of disquiet. 

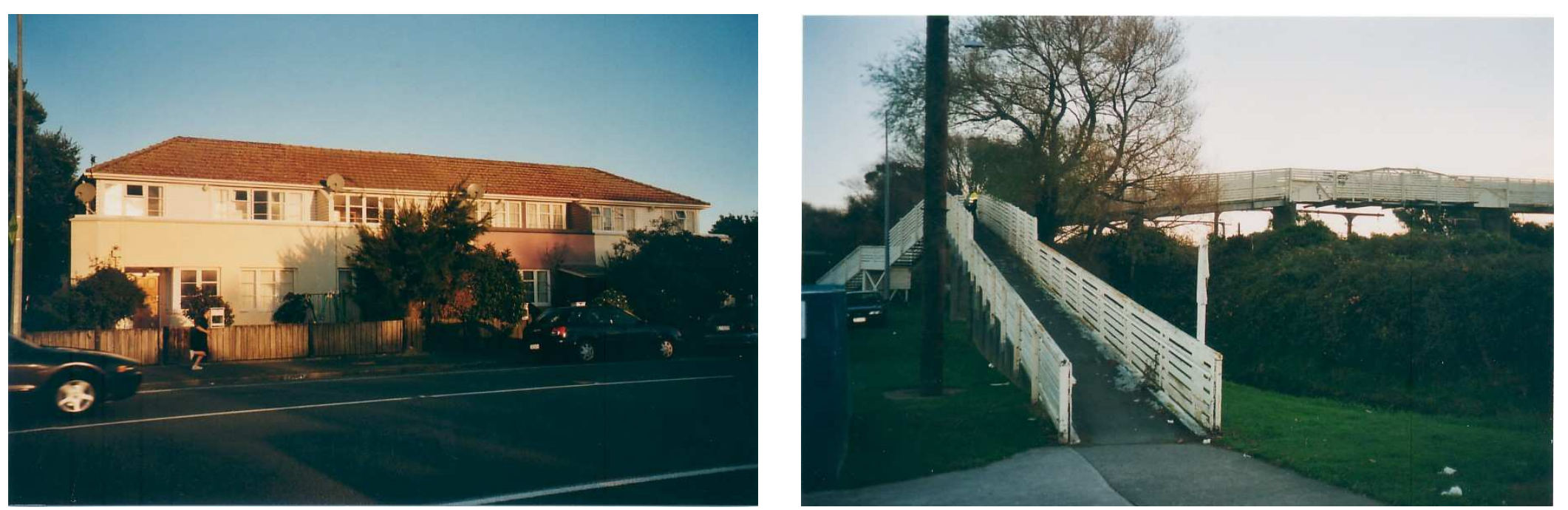

FIGURE 21

FigURE 22
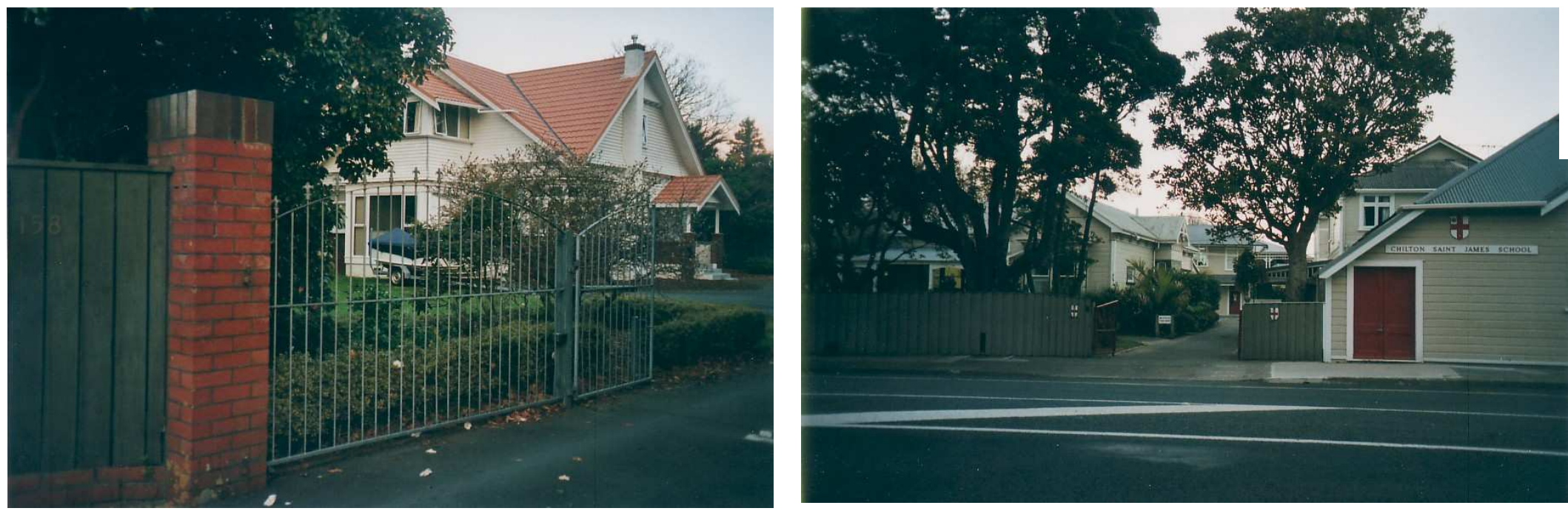

FIGURE 23

FIGURE 24 


\section{CHAPTER 8}

\section{Conclusion}

The patterning that characterises each of Gee's novels for children is characteristic of the five historical novels as a whole. Set in the past and so seemingly prophetic, they move sequentially through parallel overlapping chronologies to form an overall symmetry. The Fire-Raiser recalls World War I but is a precursor of World War II. The Champion is set in World War II and anticipates the sixties and seventies hippies. Set during the Depression, The Fat Man forewarns of Muldoonism and the near depression of the seventies and eighties. With a post-Cold War setting in 1951, Orchard Street anticipates the Lange government's effective "cold war" or "blitzkrieg" in the 1980s. And set during the teen revolt of the mid 1950s Hostel Girl predicts the feminist era of the seventies to nineties. Thus, like the three volumes of the Plumb trilogy and $O$ series, Gee's five historical novels together form an integrated whole.

Further contributing to the "whole", each of the historical novels evolves out of and reverses the distinctive pattern of the one before. As we have seen, Edgar Marwick is upper class, white, a villain and English; Jackson Coop is working class, black, a hero and an American who spends time in New Zealand; and Herbert Muskie is middle class, white, a villain, and a New Zealander who spends time in America. The Champion's child protagonist is aggressive, but the child protagonist in The Fat Man is thoughtful and shy, while Bike Pike in Orchard Street conflates the two. In The Fire-Raiser quasi-English culture is depicted negatively and Lotte Stauffel's German culture is seen as positive. The Champion suggests both positive and negative influences of American culture. The Fat Man sets Americanism against New Zealand's quasi-English character, and both are depicted negatively. Orchard Street also sets English culture against Americanism to depict both as negative and, with the Dyes' sympathy for the striking wharfies, it is Russia and communism that are upheld as good. Finally in Hostel Girl English and American cultures are set against each other with each having positives and negatives, whilst Errol Parker the villain and an Anglophile brings the circle back round to the villainous English Marwick.

Continuities further bind the novels together: many characters originate in earlier novels whilst undergoing a sequential development. For example, the physically large Kitty who learns to be courageous in The Fire-Raiser is paralleled in Orchard Street in the thirteen-year-old, outspoken Teresa who is "growing breasts" (p. 36), and in Hostel Girl in the large, more fully developed, fourteen-year-old, assertive Ailsa. Similarly, quick- 
witted Noel and intuitive Phil who become respectively cowardly and courageous in The Fire-Raiser are echoed in the fourteen-year-old smart but frightened Ossie, and eighteenyear-old aggressive, sensual Les in Orchard Street. The sequence of these patterns may be regressive. "Tall and thin", Bike Pike in Orchard Street, with his "clothes peg shoulders and grasshopper legs" is "as graceful as an antelope" (p. 22) during sports, when dancing, and on social occasions. He recalls his forerunner in The Champion - the long, lean Jackson Coop who resembles an "ostrich or hyena or giraffe" (p. 39) but who is graceful when boxing and playing jazz.

These patterns occur across fantasy and historical novels. The clever but unintuitive Nick in the $O$ trilogy anticipates the witty Noel in The Fire-Raiser and the smart, cheeky Ossie in Orchard Street. Similar patterns occur across the novels for children and adults, particularly in Prowlers and Ellie and the Shadow Man which, of course, are sequels to The Fire-Raiser and Hostel Girl and use the same or similar nomenclature. Thus Noel and Kitty Wix, Phil Miller, Irene Chalmers, and Edgar Marwick in The Fire-Raiser are paralleled in Noel and Kitty Papps, Phil Dockery, Irene Lomax and Edgar le Grice in Prowlers. And Ailsa McGowan, Calum Page and Gloria Wood in Hostel Girl become Ellie Crowther, Hollis Prime and Dolores Wood in Ellie and the Shadow Man. Even when sequels to the junior novels are lacking, continuities in nomenclature occur. In Going West Melva, Austin, Les and Rex Petley, and Verna recall, or anticipate Melva Dyer in The Fire-Raiser, Austin/Ossie and Les Dye in Orchard Street, Rex Pascoe in The Champion and Verna in The Fat Man. Of course, the fact that Gee sets several of his novels in Loomis means that references to landmarks and locations such as Ah Lap's dairy, Cascade Park, Millbrook Road, Loomis Creek, and the Waitakeres recur. Gee therefore depicts a world that is fictional, but also on-going, substantial and real.

Patterns of continuity incorporate image and undergo a repetitive progression from implicit to explicit, substance to surface, and unreal to real. For instance, the obese halfmen of the mythical underworld of The Halfmen of $O$ (1982) are recalled by "a fat man" in Motherstone (pp.55-56) and surface in Sole Survivor (1983) as a real character Alaric Gibbs - a "fat man" (p. 115). In The Fire-Raiser (1986) it is merely a personified object - Marwick's hydraulic ram - that is likened to "a fat man" (p. 79). Then in The Fat Man (1994) Herbert Muskie, a real "fat man", bursts into the everyday world of Loomis. As though O's halfmen, ascending from myth and past novels, are finally fully realised in flesh as a major character, Muskie is "like something that [has] rushed into the daylight from the back of a cave" (p. 14). Seen briefly as the individual "Herbert Muskie" by Colin, before returning to myth and the element from which he originally emerged, he perhaps awaits incarnation in a subsequent novel. The fat man's changing 
status is thus evidence of Gee's fascination with movement, resonance, layering and depth.

Gee's patterning implicitly incorporates historical reality. Bike with his “jacket so long it looked like a skirt" (p. 24), and the introverted Ossie and rebellious Lesley in Orchard Street anticipate the teddy boys with their Edwardian jackets, the leather-clad milkbar cowboys, and wild ones - James Dean, Elvis Presley, and Marlon Brando - of the Hostel Girl era. And the obese halfmen who inhabit a beehive and may be analogous to Robert Muldoon in The Halfmen of O, anticipate "Rob Mudloon" (p. 161) in Sole Survivor, and Herbert Muskie who strongly resembles Muldoon.

As I have demonstrated, Gee establishes authentic historical settings. By entering into the minds of his characters, and by showing them to be absorbing and responding to events, Gee also establishes authentic historical perspectives. In fusing with his protagonists who in turn fuse with the worlds around them, Gee ensures the child reader's imaginative participation in the stories. Linguistic and numerological structures, and the interwoveness of history, culture, myth, cosmic forces, and characters all with each other, contribute to the novels' extraordinarily rich textures. The child reader is provided with an intensely patterned and reassuringly meaningful universe that counterbalances the presentation of evil, darkness, and the metaphysical void.

To return again to Raymond Sole's words: “Everything's there. The work's all done. But I can't bring it together.' I could not make a whole round life. I lacked the stillness and the breadth; I lacked the measure. I had the energy for it but found that I needed tranquillity too" (p. 199). Like Raymond, Gee gets "everything” in. In doing so, he exercises "energy", and he creates much movement in his novels. But Gee goes further. He not only explores parts, but also brings them "together"; and constructs rounded characters, whole lives, and whole, rounded novels. In his vast range of references he exhibits "breadth", and in the fusing of these together, and the resonance that results he exhibits "depth". Finally, through creating characters and stories that are anchored by history and the imagination, and that thus have weight, he finds "stillness", "measure", and "tranquility".

Thus Bart Somers' words in Games of Choice seem even more ironic: "History is more science than an art [...]. It's the search for the pure incontrovertible fact. Rather like dissection. One lays each part out to see - one makes a list, an inventory. But no interpretation. No 'intuitive leap'. That's novel-writing, not history. [ . . . ] Fact alone is pure" (pp. 87-88, 91). For Gee history is certainly more than science, the dissection and listing of parts, and pure fact, although these are included in his books. But having divided things into parts and explored them, Gee weaves the parts together. 
History becomes art, interpretation, intuition, and novel-writing. It is Gee's preoccupation with wholeness, as represented by history in its broadest sense, that shapes his writing of fiction for children. 


\section{BIBLIOGRAPHY}

Unauthored books, periodicals, motion pictures, and internet articles are listed alphabetically by title.

Amery, Mark. “Territorial Imperative.” Quote Unquote 36, June 1996, 12-13.

Baigent, L. E. H. “An Early Incident.” Journal of the Nelson Historical Society 1/2, May 1957, 14-15.

Barnes, Jock. Never a White Flag. Wellington: Victoria University Press, 1998.

Bassett, Michael. Confrontation '51: The Waterfront Dispute. Wellington: A. H. \& A. W. Reed, 1972.

Bateman, David. New Zealand Yesterdays. Auckland: Reader's Digest, 2001.

"The Battle of Guadalcanal"

< http://www.janeresture.com/guadal/secondworldwarcametothesou.htm $>$, accessed 23 August 2004.

"Battle of Kettle Creek." New Georgia Encyclopedia $<$ http://www.georgiaencyclopedia.org/nge/Article.jsp?id=h-1088>, accessed 12 August 2004.

Beale, Fleur. "Secrets and Lies." New Zealand Books 10/1, March 2000, 4.

Bond, D. The Archetype of Renewal: Psychological Reflections on the Aging, Death and Rebirth of the King. Toronto: Inner City Books, 2003.

Bonner, Neville. "Sister Elizabeth Kenny"

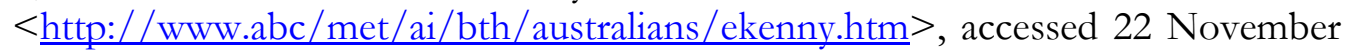
2005.

Boock, Paula. “Children's Books - What Message?” "Letters." New Zealand Listener, 1 July 1995, 13.

"The Book of Enoch the Prophet: Chapters LLI-LX" < $\underline{\text { http://sacred- }}$ texts.com/bib/bep/bep04.htm>, accessed 27 June 08.

Boyd, Brian. "Maurice Gee: Ironies of Growth and Judgement. Part II: Structure and Irony in Plumb." Islands 8/1, June 1981, 136-160.

Boyd, Brian. "Maurice Gee/Interviewed by Brian Boyd." In In the Same Room: Conversations with New Zealand Writers, eds. Elizabeth Alley and Mark Williams. Auckland: Auckland University Press, 1992, pp. 159-173.

Boyd, Brian. "The Plumb-Sole Line." New Zealand Listener, 16 July 1983, 98-99.

Braunias, Steve. “Our Man in Loomis.” New Zealand Listener, 24 July 2004, 50-54. 
Brett, Cate. “The Gee Genius.” North and South, September 1995, 92-101.

Brigadoon. Vincente Minelli, dir. MGM. Video. Wellington: The Te Aro Street Video Shop, 2008.

Brooke, Agnes Mary. "Children's Fiction - What Message?" "Letters." New Zealand Listener. 10 June 1995, 14.

Brown, Joanne. "Historical Fiction or Fictionalized History? Problems for Writers of Historical Novels for Young Adults." The Allan Review 26/1, Fall 1998

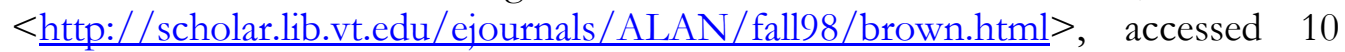
June 2005.

Browning, Robert. "Rabbi Ben Ezra." In The Complete Works of Robert Browning, eds. John C. Berkey, Allan C. Dooley, and Susan E. Dooley. Ohio: Ohio University Press, 1996, pp. 226-234.

Butler, Dorothy. "Children's Fiction - What Message?” Letters." New Zealand Listener, 13 May 1995, 12, and 22 July 1995, 12-13.

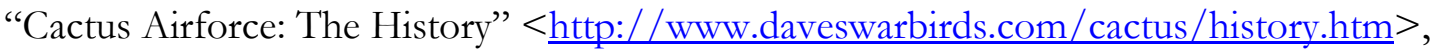
accessed 12 August 2004.

Cashin, Edward J. The King's Ranger: Thomas Brown and the Revolution on the Southern Frontier. Georgia: University of Georgia Press, 1989.

The Champion. 62/1587, 28 June 1952.

The Champion Annual for Boys 1950, ed. Hal Wilton.

Clark, Louise. Writing Vertically and Horizontally: The Relationship between Maurice Gee's Fiction for Children and for Adults. M.Phil. thesis, University of Waikato, 2004.

Clark, Louise. "The Shadow Behind the Story: The Dangerous World of Maurice Gee's Children's Books." Paper presented at The Place of the Child in Children's Literature. Weekend Symposium, University of Auckland, December 2005.

Cohen, Stanley. Folk Devils and Moral Panics: The Creation of the Mods and Rockers. Oxford: Martin Rol, 1980.

Copson, Belinda. "Children's Historical Fiction: A Personal Assessment" $<$ http://www.historicalnovelsociety.org/solander $\% 20$ files/chf.htm $>$, accessed 1 April 2005.

Cox, Nigel. "Interview with Maurice Gee.” Quote Unquote 2, July 1993, 21-23.

Cunningham, Kevin. "In My Father's Den and Maori Girl." In The New Zealand Novel. Wellington: School Publications Branch of the Department of Education, 1980, pp. 18-31.

Day, Lorain and Plant, Tim. On this Day - New Zealand's Historic Moments. New Zealand: Reed Publishing (NZ) Limited, 2002. 
"Dennis Wheatley - Devil, Witch \& Atlantis"

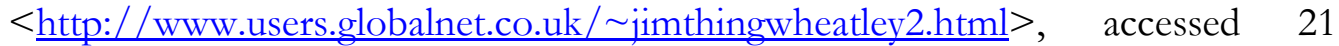
August 2006.

Dickens, Charles. The Pickwick Papers. Hertfordshire: Wordsworth Classics, 1993/2000.

"Diethylstilbestrol (Stilboestrol)" $<$ http://www/camcerbacup.org.uk/Treatments/Hormonaltherapies/Individualhor monalth...>, accessed 24 November 2005.

Duder, Tessa, Wayne Mills, and Hine Elder. "Children's Fiction - What Message." "Letters." New Zealand Listener, 3 June 1995, 14.

Duder, Tessa. "Gee’s The Fat Man." "Letters." New Zealand Listener, 19 June 2004, 7-8.

Dugdale, Sarah. "A Postcolonial Body: Maurice Gee in the 1990s." Span 42/43, April/October 1996, 30-41.

Dupuy, R. Ernest and Dupuy, Trevor N. The Collins Encyclopedia of Military History. Glasgow: Harper Collins Publishers, 1993.

Edmond, Lauris. "Definitions of New Zealanders: the Stories of Maurice Shadbolt and Maurice Gee." In Critical Essays on the New Zealand Short Story, ed. Cherry Hankin. Auckland: Heinemann, 1982, pp. 132-149.

Eliot, George. Middlemarch. Auckland: Penguin Books, 1979.

Evans, Richard. Socialism. London: Hamish Hamilton, 1977.

Farmer, Alan and Vivienne Sanders. An Introduction to American History: 1860-1990. London: Hodder and Stoughton, 2007.

"Film Noir" < http://www.crimeculture.com/Contents/Film\%20Noir.html>, accessed 24 April 2006.

"Film Noir" < http://www.filmsite.org/filmnoir.thml>, accessed 24 April 2006.

"Film Noir." Wikipedia <http://en.wikipedia.org/wiki/Film noir>, accessed 24 April 2006.

Fitzgibbon, Tom with Barbara Spiers. "Gee, Maurice Gough.” In Beneath Southern Skies: New Zealand Children's Book. Authors and Illustrators. Auckland: Ashton Scholastic, 1993, pp. 67-69.

Fox, Alistair. The Ship of Dreams: Masculinity in Contemporary New Zealand Fiction. Dunedin: Otago University Press, 2008.

Gee, Maurice. "Beginnings.” Islands 5/3, March 1977, 284-292.

—. The Big Season. Wellington: Allen \& Unwin/Port Nicholson Press, 1985.

. Blindsight. Auckland: Penguin Books, 2005. 
_. The Burning Boy. Auckland: Viking, 1990.

- The Champion. Auckland: Puffin Books, 1989.

_. Collected Short Stories. Auckland: Penguin Books, 1986.

_. "Creeks and Kitchens - The Margaret Mahy Lecture." The Inside Story; Year Book 2002. Auckland: Storylines, Children's Literature Foundation of New Zealand, 2002, 11-24.

. Crime Story. Auckland: Penguin Books, 1994.

_. "Early Reading." Education 24/8, 1975, 25.

_. Ellie and the Shadow Man. Auckland: Penguin Books, 2001.

_. The Fat Man. Auckland: Viking, 1994.

_. The Fire-Raiser. Auckland: Puffin Books, 2003.

_. Games of Choice. London: Faber and Faber Limited, 1976.

_. Going West. London: Faber and Faber, 1992.

_. Gool. Auckland: Puffin Books, 2008.

—. The Halfmen of O. Auckland: Puffin Books, 1982.

_. Hostel Girl. Auckland: Puffin Books, 1999.

. In My Father's Den. Auckland: Oxford University Press, 1977.

. Live Bodies. Auckland: Penguin Books, 1998.

. Loving Ways. Auckland: Penguin Books, 1996.

- Meg. Auckland: Faber and Faber Limited in association with Penguin Books, 1981.

_. Motherstone. Auckland: Puffin Books, 1988.

_. "A New Home for the Napier Public Library." New Zealand Libraries, February 1972, 25-29.

—. Nelson Central School: A History. Nelson: Nelson Central School Centennial Committee, 1978.

_. Orchard Street. Auckland: Viking, 1998.

_. Plumb. Auckland: Penguin Books, 2000.

_. The Priests of Ferris. Auckland: Puffin Books, 1984. 
_. Prowlers. London: Faber and Faber Limited, 1989.

_. Salt. Auckland: Penguin Books, 2007.

. The Scornful Moon. Auckland: Penguin Books, 2003.

. Sole Survivor. Auckland: Penguin Books, 1984.

. A Special Flower. London: Hutchinson, 1965.

. Under the Mountain. Auckland: Puffin Books, 1982.

. “The Way of a Writer.” New Zealand Listener, 17 January 1987, 40-42.

. The World Around the Corner. Wellington: Oxford University Press, 1980.

Glamuzina, Julie and Laurie, Alison. Parker \& Hulme: A Lesbian View. Auckland: New Women's Press, 1991.

Glasson, Toni and Carroll, John. Exploring Film as Text. Australia: Rigby Heinemann, 1992.

Grant, David (ed). The Big Blue. Christchurch: Canterbury University Press, 2004.

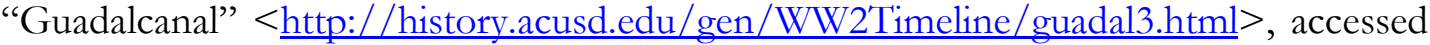
12 August 2004.

"Guadalcanal" $\quad<$ http://www.army.mil/cmh-pg/brochures/72-8/72-8.htm $>$, accessed 12 August 2004.

"Guadalcanal Canal Diary (1943)"

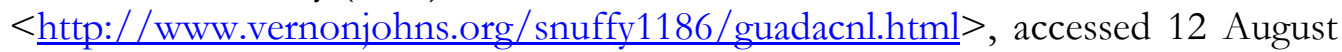
2004.

Hale, Elizabeth. "Representation and Responsibility in Under the Mountain." Paper presented at the European Association for Studies of Australia Conference, Denmark, 28 September 2007.

Haley, Russell. "The Splinterview 6: Maurice Gee.” Spleen 6, December 1976, unpaginated.

Hebley, Diane. The Power of Place: Landscape in New Zealand Children's Fiction, 1970-1989. Dunedin: Otago University Press, 1998.

"Herbert Sutcliffe 1886-1971" $<$ http://www.nzhistory.net.nz/Gallery/RadiLiv/sutbiog.htm $>$, accessed 7 June 2005.

Hewitson, Michele. “Secrets \& Lives.” New Zealand Herald, 14 March 1998, G14.

Hill, David. Introducing Maurice Gee. Auckland: Longman Paul Limited, 1981. 
Hofstadter, Richard; William Miller, Daniel Aaron, Winthrop D. Jordan, and Leon F. Litwack. The United States. New Jersey: Prentice-Hall Inc., 1976.

Holloway, Judith. "A Fat Boy, a Creek and a Personal Responsibility." New Zealand Books 5/3, August 1995, 22-24.

Huber, Raymond. "Children's Fiction - What Message?" "Letters." New Zealand Listener, 24 June, 1995, 14.

Hunt, Graeme. Black Prince: The Biography of Fintan Patrick Walsh. Auckland: Penguin Books, 2004.

Hunt, Peter. Criticism, Theory, and Children's Literature. Oxford: Basil Blackwell, 1991.

"Ibn Ezra, Abraham ben Meir"

< $\underline{\text { http://www.encyclopedia.com/html/I/IbnEzra.asp> }}$, accessed 8 March 2005.

Jacobs, A.E. "The Sinking of HMS Repulse and Prince of Wales"

<http://www.rnzncomms.net.nz/jackharker/chapt13/Sinkingofrepulse.html>, accessed 23 August 2004.

James, Trevor. "Beyond Realism: Maurice Gee and a Critical Praxis." Journal of New Zealand Literature 14, 1996, 107-126.

Jaroszczak, P. "The History of Przemysl”

< http://www.kk.krakow.pl/pioinf/prqemysl/dzieje e.html>, accessed 12 February 2007.

Jenkins, Philip. A History of the United States. London: MacMillan Press Ltd, 1997.

Johansson, Jon. Two Titans: Muldoon, Lange and Leadership. Wellington: Dunmore Publishing, 2005.

Jones, Lawrence. Barbed Wire and Mirrors: Essays on New Zealand Prose. Dunedin: University of Otago Press, 1990.

Jones, Lawrence. "Most Significant Work in NZ Realism." New Zealand Books, September 1994, 7-8.

Jones, Lawrence. "New Zealand Realism: Retrospect and Prospect." Landfall 160, 40/4, December 1986, 472-486.

Jones, Lawrence. Picking up the Traces: The Making of a New Zealand Literary Culture 19321945. Wellington: Victoria University Press, 2003.

Jung, Carl Gustave. Dreams. London and New York: Routledge Classics, 2004.

. Four Archetypes. London and New York: Routledge Classics, 2003.

- (author and ed.). Man and his Symbols. London: Aldus Books Limited, 1964.

. On the Nature of the Psyche. London and New York: Routledge Classics, 2001. 
Kamla, Gary. "You, Sir, are an Unmitigated Cad!"

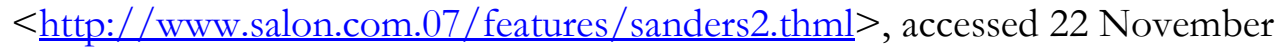
2005.

Keats, John. Endymion. In John Keats, ed. Elizabeth Cook. Oxford: Oxford University Press, 1990, pp. 60-163.

Kedward, H.R. Fascism in Western Europe 1900-45. Glasgow: Blackie \& Son Limited, 1969.

King, Michael. The Penguin History of New Zealand. Auckland: Penguin Books, 2003.

Larsen, David. “So Much for Retirement.” New Zealand Listener, 24 May 2008, 38-41.

Lasenby, Jack. "Children's Books - What Message?” "Letters.” New Zealand Listener, 1 July 1995, 13.

Laurel and Hardy Way Out West. Universal Pictures, 1937. DVD. Wellington: The Te Aro Street Video Shop, 2008.

Laws, Michael. “Talent and Truth.” The Dominion, 5 May 2001, Supp. 13.

Leibowitz, Jeannine. "Shaping Fantasies: A Comparative Study of Three New Zealand Children's Authors.” M.A. thesis, Victoria University of Wellington, 1997.

Lewis, Peter. The Fifties. London: Heinemann, 1978.

Longfellow, H. W. Hyperion. In The Prose Works of H. W. Longfellow. London: Cassell and Company Limited, pp. 171-320.

McCloud, Scott. Understanding Comics - The Invisible Art. New York: Harper Collins Publishers, 1994.

McGillis, Roderick. The Nimble Reader: Literary Theory and Children's Literature. New York: Twayne Publishers, 1996.

McLauchlan, Gordon. The Passionless People. Auckland: Cassell, 1976.

McLean, Patricia. "The Possibility of Love: Masculinities in the Novels of Maurice Gee.” Ph.D. thesis, Victoria University of Wellington, 2005.

McLeod, Marion. “A Champion Tale.” New Zealand Listener, 7 October 1989, 29.

McPherson, James. Fields of Fury - The American Civil War. New York: Byron Preiss Visual Publications, Inc. 2002.

Maharey, Steve and Mike O'Brien (eds). Alternatives: Socialist Essays for the 1980s. Palmerston North: Massey University, 1986.

Manhire, Bill. Maurice Gee. In the series New Zealand Writers and their Work. Auckland: Oxford University Press, 1986. 
Mann, Shonadh. F. G. Gibbs: His Influence on the Social History of Nelson, 1890-1950. M.A. thesis. Nelson: The Nelson Historical Society, 1977.

Manning, A. W. The Bodgie: A Study in Abnormal Psychology. Wellington: A. H. \& A. W. Reed, 1958.

Marriot, Janice. "Stalker Story is Less Violent than Earlier Teen Chillers." The Dominion, 24 July 1999, 20.

Masefield, John. "Cargoes." In John Masefield: Selected Poems, ed. Donald Stanford. Manchester: Carcanet Press, 1984, pp. 97-98.

Mazengarb, Oswald Chettwin (chairman). Report of the Special Committee on Moral Delinquency in Children and Adolescents. Wellington: R.E. Owen Government Printer, 1954.

Mein Smith, Philippa. A Concise History of New Zealand. Melbourne: Cambridge University Press, 2005.

"Men of Harlech." Data Wales < http://www.data-wales.co.uk/harlech.htm $>$, accessed 13 August 2002.

Mildred Pierce. Michael Curtiz, dir. Warner Brothers, 1945. Video. Wellington: The Te Aro Street Video Shop, 2008.

"Mildred Pierce" < http://www/dvdta:lcp,/dvdsavant/s706pierce.html>, accessed 22 November 2005.

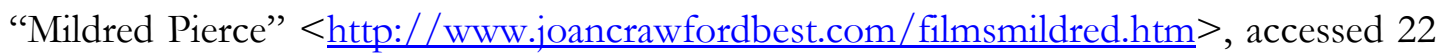
November 2005.

"Mildred Pierce" < http://www.nicksflickpicks.com/com/mildred.html $>$, accessed 22 November 2005.

Miller, Ron and William K. Hartmann. The Grand Tour: A Traveler's Guide to the Solar System. New York: Workman Publishing Company, 2005.

Milton, John. Paradise Lost. Auckland: Penguin Books, 2003.

Mirams, Gordon. Speaking Candidly: Films and People in New Zealand. Hamilton: Paul's Book Arcade, 1945.

Molloy, Maureen. "Science, Myth and the Adolescent Female: The Mazengarb Report, the Parker-Hulme Trial, and the Adoption Act of 1955." Women's Studies Journal 9/1, March 1993, 1-25.

Monkman, Leslie. "From Plumb to Prowlers: Maurice Gee's Octogenarians." Australian \& New Zealand Studies in Canada 3, Spring 1990, 9-22.

Nieuwenhuizen, Agnes. "Know the Author: Maurice Gee. Creek, Kitchen, \& the Art of Language." Magpies New Zealand 1, March 1997, 4-6. 
Nikolajeva, Maria. Children's Literature Comes of Age: Towards a New Aesthetic. New York and London: Garland Publishing, 1996.

Nolan, Jennie. "Prohibition: How Detroit Became a Bootlegger's Dream Town." The Detroit News < http://www.detnews.com/history/prohib/prohib.htm>, accessed 3 December 2003.

Noonan, Michael. "N.Z. is his Subject." Critic 4, March 1964, 5.

Norton, David. "Life on the Edge of Death." Climate 29, Autumn 1979, 54-67.

Nozedar, Adele. The Element Encyclopedia of Secret Signs and Symbols. London: Harper Element, 2008.

O’Brien, Gregory. "Making Sentences Work." In Moments of Invention: Portraits of 21 New Zealand Writers, ed. Gregory O’Brien. Auckland: Heinemann Reed, 1988, pp. 112118.

Oliver, W. H. “The Awakening Imagination." In The Oxford History of New Zealand, ed. Geoffrey W. Rice. Auckland: Oxford University Press, 1992, pp. 539-570.

Papprill, Alan. "The Fat Man: A set of lessons designed for Year 10"

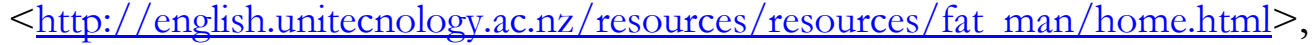
accessed 20 Nov. 2003.

Pearson, Bill. "Fretful Sleepers." In Fretful Sleepers and Other Essays. Auckland: Heinemann Educational Books, 1974, pp. 1-32.

Perry, Nick. "Flying by the Nets: The Social Pattern of New Zealand Fiction." Islands 3/2, December 1987, 161-177.

"Police Hunt for Signs of Arson." The Nelson Evening Mail, 7 February 1981, 1-3.

Porter, J.R. The Lost Bible: Forgotten Scriptures Revealed. London: Duncan Baird Publishers, 2001.

Prakash, Som. "Dislocations, Distortions and Resolutions in Maurice Gee's Fiction." Span 34/35, May 1993, 118-140.

Prakash, Som. "Fantasy and Flight in the Novels of Maurice Gee." New Zealand Literature Today, ed. R. K. Dhawan. New Delhi: Indian Society for Commonwealth Studies, 1993, pp. 150-160.

Prebble, Zoe. "Children’s Fiction - What Message?" "Letters." New Zealand Listener, 1995, 14.

Purcell, Uta. "The Fat Man by Maurice Gee: Who is the Implied Reader?" Talespinner 2, November 1996, 44-50.

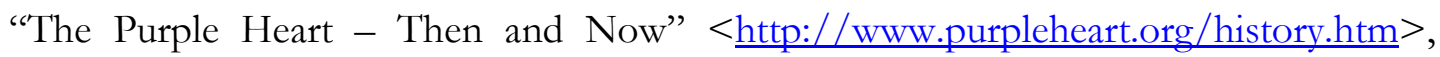
accessed 12 August 2004. 
Reilly, Colleen. "An Interview with Maurice Gee." Australian and New Zealand Studies in Canada 3, Spring 1990, 1-8.

Rose, Andrea. The Pre-Raphaelites. London: Phaidon Press Limited, 1981.

Ross, Stewart. The American Revolution. London: Evans Brothers Ltd, 2001.

Sargeson, Frank. The Stories of Frank Sargeson. Auckland: Penguin Books, 1982.

Scarface. Howard Hawks, dir. 1932. DVD. Wellington: The Te Aro Street Video Shop, 2008.

Scott, Dick. 151 Days. Auckland: Southern Cross, third (abridged) edition, 1954.

Scott, Dick. Pioneers of New Zealand Wine. Auckland: Reed/Southern Cross, 2002.

Scott, Dick. A Stake in the Country: Assid Abraham Corban and his Family, 1892-2002. Auckland: Reed, 2002.

Shakespeare, William. The Complete Illustrated Shakespeare, ed. Howard Staunton. Bombay: Lalvani Publishing House, 1989.

Shuker, Roy and Roger Openshaw, with Janet Soler. "Youth, Media \& Moral Panic in New Zealand." Delta Research Monograph 11, 1990.

Simkins, Peter; Jukes, Geoffrey \& Hickey, Michael. The First World War: The War to End All Wars. Great Britain: Osprey Publishing Limited, 2003.

Simpson, Tony. The Slump - The Thirties Depression: Its Origins and Aftermath. Auckland: Penguin Books, 1990.

Simpson, Tony. The Sugarbag Years. Wellington: Alister Taylor Publishing Limited, 1974.

Sinclair, Keith (ed). The Oxford Illustrated History of New Zealand. Auckland: Oxford University Press, 2001.

Sinclair, Keith and Wendy Harrex. Looking Back: A Photographic History of New Zealand. Wellington: Oxford University Press, 1978.

Soler, Janet. "That Incredible Document Known as the Mazengarb Report." Sites 2, Spring 1989, 22-32.

Stead, C. K. "Maurice Gee, Moralist.” Landfall 202, November 2001, 98-105.

Stevens, Anthony. Private Myths: Dream and Dreaming. Cambridge, Massachusetts: Harvard University Press, 1996.

Stone, Brenda. "Human Cruelty Explored." English in Aotearoa, December 1996, 92-93.

Stuart, Sarah. "Gentle Gee has a Grip on all Ages.” Sunday Star Times, 23 April 1995, D3. 
Taylor, A. J. P. (ed.). History of World War I. London: Octopus Books Limited, 1974.

Topham, Gloryroad. "Dickensian Grotesque in Maurice Gee's The Fat Man" $<\underline{\text { http://dadashopping.net/work.php?code=dickensian grotesque }}>$, accessed 16 July 2007.

Uglow, Nathan. "Historical Novel." Literary Encyclopedia: Historical Novel $<\underline{\text { http://www.litencyc.com/php/stopics.php?rec=true\&UID }=1213>}>$ accessed 13 December 2004.

van Rij, Vivien. "Interview with Maurice Gee." (Unpublished.) Wellington: 9 December 2003.

van Rij, Vivien. “'A Straight Steal': 'An Affair of the Heart' and Maurice Gee's The Fat Man." Kotare 6, 2006, <http://www.nzetc.org/tm/scholarly/tei-Whi06Kota.htm>, accessed 27 November 2007.

Verne, Jules. Twenty Thousand Leagues Under the Seas. Oxford: Oxford University Press, 1998.

Walls, Kathryn. "Maurice Gee's Debt to 'Double Unit': The Influence of Lyndahl Chapple Gee's Short Story on The Halfmen of O." Wellington: Stout Research Seminar, Victoria University, 2005.

Walls, Kathryn. "My Mother was a Writer.” New Zealand Books 16/5, December 2006, 12.

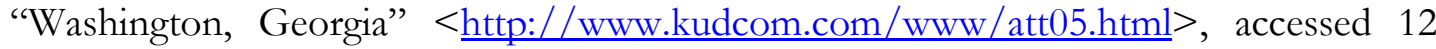
August 2004.

Wattie, Nelson. "Maurice Gee." InThe Oxford Companion to New Zealand Literature, eds. Roger Robinson and Nelson Wattie. Auckland: Oxford University Press, 1998, pp. 197-199.

Welch, Denis. “Gee Gee: Maurice Gee’s Brilliant Plagiarisms of Maurice Gee.” New Zealand Listener, 12 May 2001, 58-59.

Williams, Mark. Leaving the Highway: Six Contemporary New Zealand Novelists. Auckland: Auckland University Press, 1990.

Williamson, Jim. “The Potent Beast.” Islands 1/1, 1972, 74-79.

Winsbury, Rex. Communism. London: Hamish Hamilton, 1978.

"World War I Battlefields: Other Battlefields: Neuve Chapelle"

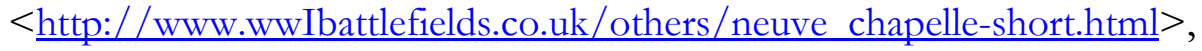
accessed 12 February 2007.

Yin/Yang http://www/wsu.edu/ dee/CHPHIL/YINYANG.HTM, accessed 13 February 2008.

Young, David. "Maurice Gee: 'Non-aligned' Novelist." New Zealand Listener, 10 February 1979, 16-17.

Yska, Redmer. All Shook Up. Auckland: Penguin Books, 1993. 


\section{Acknowledgements and Abstract}

1 Towards the end of his life Plumb quotes Robert Browning's "Abt Vogler": "On the earth the broken arcs; in the heaven a perfect round". See Maurice Gee, Plumb (Auckland: Penguin Books, 2000), p. 254. All quotations from Plumb are from this edition.

2 Maurice Gee, Prowlers (London: Faber and Faber Limited, 1989). All quotations are from this edition.

\section{Chapter 1}

1 Maurice Gee, Games of Choice (London: Faber and Faber, 1976). All quotations are from this edition. Vivien van Rij, "Interview with Maurice Gee” (Wellington: 9 December 2003).

3 Maurice Gee, Going West (London: Faber and Faber, 1992). All quotations are from this edition.

4 Nathan Uglow, "Historical Novel". Literary Encyclopedia: Historical Novel <http://www.literacyc.com/php/stopics.php?rec+true\&UID=1213 >, accessed 13 Dec. 2004.

5 W. H. Oliver, "The Awakening Imagination". In The Oxford History of New Zealand, eds. W. H. Oliver and B. R. Williams (Auckland: Oxford University Press, 1992), p. 564.

6 van Rij, Gee, "Interview".

7 For Gee's comments see Maurice Gee, "Creeks and Kitchens - The Margaret Mahy Lecture”. The Inside Story: Yearbook (Auckland: Children's Literature Foundation of New Zealand, 2002), 22, 24, 20.

8 For Gee's ideal of the "whole novel" see Maurice Gee, “The Way of a Writer". New Zealand Listener (January 27, 1987), p. 42. For Gee talking to Colleen Reilly see Colleen Reilly, "An Interview with Maurice Gee". Australian and New Zealand Studies in Canada 3, 7.

9 See Steve Braunias, "Our Man in Loomis". New Zealand Listener (24 July 2004), 24-30.

10 See Brian Boyd, "Maurice Gee/Interviewed by Brian Boyd". In In the Same Room:Conversations with New Zealand Writers, eds. Elizabeth Alley and Mark Williams (Auckland: Auckland University Press, 1992), p. 171.

11 Maurice Gee quoted in David Hill. Introducing Maurice Gee (Auckland: Longman Paul, 1981), p. 53.

12 See Gee, "Creeks and Kitchens", 12-13.

13 Gee, "Creeks and Kitchens", 20-21.

14 See Leslie Monkman, "From Plumb to Prowlers: Maurice Gee's Octogenarians". Australia and New Zealand Studies in Canada 3 (Spring 1990), 16, 21-22.

15 van Rij, Gee, "Interview".

16 Gee, "Creeks and Kitchens", 22.

17 Maurice Gee, Plumb. (Auckland: Penguin Books, 1978), p. 21. All subsequent quotations are from this edition.

18 Carl Jung, Collected Works XV (1996), paragraph 213.

19 Maurice Gee, The Halfmen of O. (Auckland: Puffin Books, 1982), p. 68. All subsequent quotations are from this edition.

20 See Joseph L. Henderson in Carl G. Jung, Man and his Symbols (London: Aldus Books, 1979), p. 118.

21 Maurice Gee, Ellie and the Shadow Man (Auckland: Penguin Books, 2001). All subsequent quotations are from this edition.

22 See Jolande Jacobi in Man and his Symbols, p. 287.

23 Maurice Gee, In My Father's Den (Auckland: Oxford University Press, 1977). All subsequent quotations are from this edition.

24 Carl Jung, "Symbols of Transformation" in Collected Works, V (London: Routledge and Kegan Paul, 1956), paragraph 341.

25 M. L. von Franz in Man and his Symbols, p. 161.

26 Maurice Gee, Motherstone (Auckland: Puffin Books, 1985), p. 122. All subsequent quotations are from this edition.

27 See von Franz in Man and his Symbols, p. 213.

28 Maurice Gee, Sole Survivor (Auckland: Penguin Books, 1984). All subsequent quotations are from this edition.

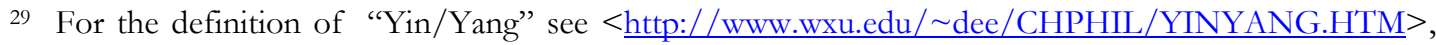
accessed 3 Feb. 2009.

30 van Rij, Gee, "Interview".

31 Carl Jung, Collected Works, XV (1966), para. 213.

32 Maurice Gee, In My Father's Den (Auckland: Oxford University Press, 1977). All quotations are from this edition.

33 Maurice Gee, Meg (Auckland: Faber and Faber, 1981). All quotations are from this edition. 
34 Maurice Gee, Ellie and the Shadow Man (Auckland: Penguin Books, 2001). All quotations are from this edition.

35 See Oliver, p. 564 and Lauris Edmond, "Definitions of New Zealanders: The Stories of Maurice Shadbolt and Maurice Gee". In Critical Essays on the New Zealand Short Story, ed. Cherry Hankin (Auckland: Heinemann, 1982), p. 142.

36 Gee, "The Way", 42.

37 Paul's quoting of Casanova - "How can a father truly love his daughter unless he has slept with her at least once" (p. 136) - underscores his mixed feelings for Celia as lover, and possible daughter.

38 Jung has defined the whole psyche as comprising two paired opposites - the persona and shadow, and the ego and soul. See M. L. von Franzen, "The Process of Individuation". In Man and his Symbols, pp. 158-229.

39 Gee, "The Way", 42.

40 This summary of the Plumb trilogy draws on Bill Manhire, Maurice Gee. (Auckland: Oxford University Press, 1986), pp. 61-69.

41 Reilly, Gee, "Interview", 4-5.

42 Edmond, p. 143.

43 See Manhire pp. 41-42.

44 Manhire, p. 49.

45 Manhire, pp. 9-12.

46 Diane Hebley, The Power of Place: Landscape in New Zealand Children's Fiction, 1970-1989 (Dunedin: Otago University Press, 1998).

47 For Fleur Beale's review of Hostel Girl see "Secrets and Lies". New Zealand Books (March 2000), 4. For Janice Marriot's review of Hostel Girl see "Stalker Story is Less Violent than Earlier Teen Chillers". The Dominion (24 July, 1999), 20.

48 Denis Welch, “Gee Gee: Maurice Gee’s Brilliant Plagiarisms of Maurice Gee”. New Zealand Listener (12 May 2001), 58-59.

49 See Lawrence Jones, "Most Significant Work in New Zealand Realism". New Zealand Books (September 1994), 7-8, and Boyd, Gee, "Interview".

50 Louise Clark, Writing Vertically and Horizontally: The Relationship between Maurice Gee's Fiction for Children and for Adults (M.Phil. thesis, University of Waikato, 2004). See also Louise Clark "The Shadow Behind the Story: The Dangerous World of Maurice Gee's Children's Books. Paper presented at The Place of the Child in Children's Literature. (Weekend Symposium, Auckland University, December 2005.)

51 For Gee on his junior fiction and narrative technique see Reilly, Gee "An Interview".

52 See Boyd, Gee, "Interview", p. 171

53 Maurice Gee speaking on Radio New Zealand National, 24 May 2008.

54 For a review of The Champion see Marion McLeod, "A Champion Tale". New Zealand Listener (7 October 1989), 29.

55 Sarah Stuart discusses parallels between Gee's childhood and his junior fiction in "Gentle Gee has a Grip on all Ages". Sunday Star Times (23 April 1995), D3. See also Allan Papprill, "The Fat Man: A Set of Lessons" < http://english.unitecnology.ac.nz/resources/resources/fat-man/home.html>, accessed 20 Nov. 2003.

56 For childhood influences see Maurice Gee, "Beginnings". Islands 5/3 (March 1977), 284-292, and Gee "The Way", 40-42. See also Gee, "Creeks and Kitchens", 11-25. Gee has described his childhood on Radio New Zealand National (9 October 2004).

57 For The Fat Man's source in Henderson see Judith Holloway, "A Fat Boy, a Creek and Personal Responsibility". New Zealand Books (August 1995), 22-23. See also Agnes Nieuwenhuizen, "Maurice Gee: Creek, Kitchen \& the Art of Language". Magpies 1 (March 1997), 4-6.

58 Letters debating The Fat Man as a junior novel appeared in "Letters to the Editor", New Zealand Listener (13 May, 3 June, 10 June, 24 June, 1 July, and 22 July 1995).

59 See Uta Purcell, “The Fat Man by Maurice Gee: Who is the Implied Reader?” Talespinner 2, November 1996), 44-50.

60 Maurice Gee talks to Mark Amery in "Territorial Imperative". Quote Unquote 36 (June 1996), 12-13.

61 For the debate over The Fat Man see Tessa Duder, "Letters to the Editor". New Zealand Listener (19 June 2004), 7-8, and Steve Braunias, "Our Man in Loomis". New Zealand Listener (24 July 2004).

62 Gloryroad Topham considers Dickens' influence on Gee in “Dickensian Grotesque in Maurice Gee’s The Fat Man" < http://dadashopping.net/work.php?code=dickensian grotesque>, accessed 16 July 2007.

63 Maurice Gee, "Early Reading”, Education 24/8 (1975), 25.

64 See Vivien van Rij, "A Straight Steal": "An Affair of the Heart" and Maurice Gee's The Fat Man" in Kotare (2006), 6 < http://www.nzetc.org/tm/scholarly/tei-Whi06Kota.html >, accessed 27 Nov. 2006.

65 Monkman, "From Plumb to Prowlers: Maurice Gee’s Octogenarians", 9-22. 
66 See Brenda Stone, "Human Cruelty Explored”, English in Aotearoa (December 1996), 92-93 and Jeanne Leibowitz, Shaping Fantasies: A Comparative Study of Three New Zealand Children's Authors, M.A. thesis, Victoria University of Wellington (1997).

67 Kathryn Walls, “Maurice Gee's Debt to 'Double Unit': The Influence of Lyndahl Gee's Short Story on The Halfmen of O". Paper presented at the Stout Research Centre, Victoria University of Wellington (25 May 2005). See also Kathryn Walls, "My Mother was a Writer". New Zealand Books (December 2006), 12.

68 See David Larsen, "So Much for Retirement”, New Zealand Listener (24 May 2008), 38-41.

69 See Uglow, "Historical Novel".

70 Joanne Brown, "Historical Fiction or Fictionalized History? Problems for Writers of Historical Novels for Young Adults" in The Alan Review 26/1, Fall 1998

http://scholar.lib.vt.edu/ejournals/ALAM/fall98/brown.html>, accessed 10 June 2005.

71 Belinda Copson, "Children's Historical Fiction: A Personal Assessment" http://www.historicalnovelsociety.org/solander\%20files/chf.htm >, accessed 1 April, 2005.

72 Maria Nikolajeva, Children's Literature Comes of Age: Toward a New Aesthetic. (New York and London: Garland Publishing, Inc., 1996). See especially chapters five, six and seven on chronotope, intertextuality, and metafiction.

73 Mark Williams, Leaving the Highway (Auckland: Auckland University Press, 1990), pp. 180-181.

74 Peter Hunt, Criticism, Theory, and Children's Literature. (Oxford, UK: Basil Blackwell Ltd, 1991).

75 Elizabeth Hale, "Representation and Responsibility in Under the Mountain. Paper presented at the European Association for Studies of Australia Conference, Denmark (28 September 2007).

76 Roderick McGillis, The Nimble Reader. (New York: Twayne Publishers, 1996).

\section{Chapter 2}

1 Maurice Gee, The Halfmen of O (Auckland: Puffin Books, 1984). All quotations are from this edition.

2 See Leibowitz, Shaping Fantasies.

3 Gee refers to Muldoon derogatorily in several of his novels. See for example Sole Survivor, p. 161

4 Maurice Gee, The Priests of Ferris (Auckland: Puffin Books, 1984). All quotations are from this edition.

5 Maurice Gee, Motherstone (Auckland: Puffin Books, 1988). All quotations are from this edition.

6 Jung has noted the term "Mana" was used by ancient tribes, Maori, and other Melanesian races to define spiritual power. See Carl Jung, On the Nature of the Psyche (London: Routledge Classics, 2001), pp. 74-77.

7 Carl Jung, Dreams (London: Routledge Classics, 2004), pp. 202-205.

8 Adele Nozedar, The Element Encyclopedia of Secret Signs and Symbols (London: Harper Element, 2008), p. 486.

9 See Anthony Stevens, Private Myths: Dreams and Dreaming (Cambridge, Massachusetts: Harvard University Press), pp. 144-162.

10 Like Adam, as he is described in the Bible and ancient scriptures, Susan spans the four directional points, takes nature into her, and has a name that integrates her with the world she explores. See for example J. R. Porter, The Lost Bible (London: Duncan Baird Publishers), p. 23.

11 See D. Stephenson Bond, The Archetype of Renewal (Toronto: Inner City Books, 2003), p. 85.

\section{Chapter 3}

1 Shonadh Mann, F.G. Gibbs: His Influence on the Social History of Nelson, 1890-1950. (Nelson: The Nelson Historical Society, 1977).

2 Nelson Wattie, "Maurice Gee". In The Oxford Companion to New Zealand Literature (Auckland: Oxford University Press, 1998), p. 198.

3 Maurice Gee, Nelson Central School: A History (Nelson: Nelson Central School Centennial Committee, 1978). All references to Nelson Central School: A History draw on this source. For Hodgson on arithmetic see pp. 28, 23. For Hodgson on drill see p. 23.

4 Manhire, Maurice Gee, p. 11.

5 Gregory O'Brien, "Making sentences work". In Moments of Invention: Portraits of 21 New Zealand Writers (Auckland: Heinemann Reed, 1988), p. 113.

6 van Rij, Gee, "Interview".

7 Boyd, Gee, "Interview", p. 167

8 L. E. H. Baigent, “An Early Incident”. Journal of the Nelson Historical Society, 1/2 (Nelson: The Society, May, 1957), 14-15.

9 According to Mann, Jessop was the name of one of Gibbs' tramping companions. 
10 van Rij, Gee, "Interview”.

11 Mann, pp. 6-10.

12 In chapter three Mrs Marwick states, "This land has been mine for fifty years" (p. 40). Presumably acquiring the property upon marriage at about twenty years of age in approximately 1865, Mrs Marwick would have been born around 1845, making the date of her immigration about 1855.

13 See Peter Simkins, Geoffrey Jukes, \& Michael Hickey, The First World War: The War to End all Wars (Great Britain: Osprey Publishing Limited, 2003), pp. 52-53.

14 "World War One Battlefields: Other Battlefields: Neuve Chapelle" <http://www.ww1battlefields.co.uk/others/neuve chapelle-short.html>, accessed 12 Feb. 2007.

15 The summary of events in and around the Dardanelles is based on Simkins, pp. 54-55, 276, 291.

16 For an account of Przemysl's history on which this summary is based see P. Jaroszczak, "The History of Przemysl" < http://www.kk.krakow.pl/pioinf/przemysl/dzieje e.html>, accessed 12 Feb. 2007.

17 Simkins, pp. 208-210.

18 Philippa Mein Smith, A Concise History of New Zealand (Australia: Cambridge University Press, 2005), p. 127.

19 See Nozedar, pp. 485-493.

20 See von Franz in Man and his Symbols, p. 310.

21 van Rij, Gee, "Interview".

22 A copy of the original pageant, Our Empire Day, is held in Gee's files at the Arthur Turnbull Library, Molesworth Street, Wellington. All quotations are from this version.

23 "Men of Harlech", Data Wales <http://www.data-wales.co.uk/harlech.htm., accessed 13 August 2002.

24 William Shakespeare, "Song", Cymbeline. In The Complete Works of Shakespeare, ed. Howard Staunton (London: Abbey Library), II, p. 724.

25 White ladies appear in Longfellow's Hyperion, Fouquet's Undine, Adrien Boieldieu's opera La Dame Blanche, Walter Scott's Guy Mannering, The Monastery, and The Abbot (on which the opera's libretto is based), and novels by Alexandre Dumas.

26 van Rij, Gee, "Interview".

27 John Keats, Endymion. In John Keats, ed. Elizabeth Cook (Oxford: Oxford University Press, 1990), p. 61.

28 Jules Verne, Twenty Thousand Leagues Under the Seas (Auckland: Oxford University Press, 1998).

29 See Henry Wadsworth Longfellow, Hyperion. In The Prose Works of H. W. Longfellow (London: Cassell and Company, Limited), p. 171.

30 See John Masefield, "Cargoes". In John Masefield: Selected Poems, ed. Donald E. Stanford (Manchester: Carcanet, 1984), pp. 97-98.

31 See John Milton, Paradise Lost (London: Penguin Books, 2000), pp. 41, 64.

32 Longfellow, Hyperion, III, p. 244.

33 Longfellow's Hyperion draws for inspiration on Goethe's novel The Sorrows of Young Werther (1774) in which the protagonist, a sensitive, passionate young artist, wanders through Europe.

34 Longfellow, Hyperion, III, p.243.

35 Gee sees the imagination as working on a deeper level: "The imagination works on a semi-conscious level, and so all sorts of things are laid down in the story that the reader can interpret in these ways. These things are on the level of accident, but a sort of serendipitous accident that maybe sends a little root down into the creative imagination. If they work for [the reader] I can't take full credit, but I can take a little credit." van Rij, Gee, "Interview".

36 See Milton, p. 50.

37 See Milton, pp. 106, 356, and Shakespeare in Staunton, II, p. 724.

38 See Milton, pp. 225-226

39 This observation draws on Bill Manhire's comment on intertextuality in the Plumb Trilogy: "The full force of $[a]$ passage depends on its context. [ . . ] The full context may occur several hundred pages earlier, in another novel. [The text] does not accumulate its meanings but releases them unexpectedly, sending echoes across vast distances". See Manhire, p. 66.

40 Gee, "The Way", p. 42.

\section{Chapter 4}

1 Michael King, The Penguin History of New Zealand (Auckland: Penguin Books, 2003). This summary of New Zealand's counter-culture draws on pp. 455-463.

2 van Rij, Gee, "Interview".

3 Maurice Gee, The Champion (Auckland: Puffin Books, 1989). All quotations are from this edition.

4 Carl Jung, Four Archetypes (London: Routledge Classics, 2004), pp. 22-23.

5 For King's formulations see pp. 471-472. 
6 This summary of Maori and Pakeha relations is based on King 467-484.

7 For New Zealand's growing awareness of racial issues see Lorain Day and Tim Plant, On this Day New Zealand's Historic Moments (New Zealand: Reed Publishing (NZ) Limited, 2002), pp. 170, 124.

8 King, p. 487.

9 For cultural identification and xenophobia see King, pp. 366-367, 370.

10 See McLeod, 29.

11 Lorain Day and Tim Plant, On this Day: New Zealand's Historic Monuments (Auckland: Reed, p. 2002), p. 63.

12 For Gee's recollections of Henderson during World War II see McLeod, 29.

13 Dick Scott, Pioneers of New Zealand Wine (Auckland: Reed/Southern Cross, 2002), pp. 89, 134.

14 Gee, "Creeks and Kitchens", 12.

15 McLeod, 29.

16 Gee, "Beginnings", 288.

17 For Gee on Rockfist Rogan, war games, the Japanese threat, and American servicemen see McLeod, 29. For further memories of US servicemen see Gee, "Creeks and Kitchens", 12.

18 "The Battle of Guadalcanal" < http://www.janeresture.com/guadal/second world war came to the sou.htm $>$, accessed 23 August 2004.

19 My summary of World War II in the Pacific draws on the following sources: A. E. Jacobs, "The Sinking of HMS Repulse and Prince of Wales" < http://www.mzncomms.net.nz/jackharker/chapt13/Sinkingofrepulse.html>, accessed 23 Aug. 2004; R. Ernest Dupuy and Trevor N. Dupuy, The Collins Encyclopedia of Military History (Glasgow: Harper Collins Publishers, 1993), pp. 135-136. "Guadalcanal Diary (1943)"

<http://www.vernonjohns.org/snuffy1186/guadacnl.html>, accessed 12 Aug. 2004; "Cactus Air Force: The History" < $<$ http://www.davewarbirds.com/cactus/history.htm>, accessed 12 August 2004; "Guadalcanal", <http://www.army.mil/cmh-pg/brochures/72-8/72-htm>, accessed 12 August 2004; and "Guadalcanal" <http://history.acusd.edu/gen/WW2Timeline/guadal3.html>, accessed 12 August 2004.

20 For racial issues in the United States see Alan Farmer and Vivienne Sanders, An Introduction to American History: 1860-1990 (London: Hodder \& Stoughton, 2007), p. 157.

21 On America's race riots see Hofstadter, Richard, et al., The United States (New Jersey: PrenticeHall, 1976), pp. 524-526.

22 For America's Civil War see James M. McPherson, Fields of Fury - The American Civil War (New York: Byron Preiss Visual Publications, Inc. 2002), pp. 5-91.

23 On Lincoln see Farmer and Sanders, pp. 26, 37.

24 For the "dark age" see Philip Jenkins, A History of the United States (London: MacMillan Press Ltd, 1997), pp. 149-150.

25 Stewart Ross, The American Revolution (London: Evans Brothers Ltd, 2001), pp. 12-54.

26 "Washington, Georgia" < http://www.kudcom.com/www/att05.html>, accessed 12 August 2004.

27 "Battle of Kettle Creek." New Georgia Encyclopedia

$<$ http://www.georgiaencyclopedia.org/nge/Article.jsp?id=h-1088>, accessed 12 August 2004.

28 Jackson's death in 1806 precluded him from the cowardly role allotted to him by Thomas Brown. See Edward J. Cashin, The King's Ranger: Thomas Brown and the Revolution on the Southern Frontier (Georgia: University of Georgia Press, 1989), pp. 213, 240-241.

29 See "The Purple Heart - Then and Now", <http://www.purpleheart.org/history.htm>, accessed 12 Aug. 2004.

30 Jenkins, pp. 51-52.

31 See The Champion 62 (28 June 1952), 9.

32 According to Scott McCloud "The cartoon is a vacuum into which our identity and awareness are pulled...An empty shell that we inhabit which enables us to travel in another realm." It is "a blank slate (an) iconic (cartoony) form" that is given life by being filled up by the reader. See Scott McCloud, Understanding Comics - The Invisible Art (New York: Harper Collins Publishers, 1994), pp. 2837.

33 For a description of Rockfist Rogan in West Africa see Hal Wilton, "Rockfist Rogan - The Boxing Airman". In The Champion Annual for Boys (1950), pp. 141-151.

34 Champion Annual, pp. 141-151.

35 Champion Annual, pp. 141,151. 


\section{Chapter 5}

1 van Rij, Gee, "Interview".

2 Gee's Depression-period novels include In My Father's Den (partly set in Wadesville, an early version of Henderson); the Plumb trilogy (set in Loomis, a version of Henderson); and Going West (which looks retrospectively at Loomis in the 1930s).

3 van Rij, Gee, "Interview".

4 See Gee, "Creeks and Kitchens", 12.

5 Allan Papprill provided information on Henderson's landmarks that appear in The Fat Man during a telephone conversation with Vivien van Rij (Wellington, March 2004). See also Papprill, "The Fat Man: A Set of Lessons".

6 Gee, "Creeks and Kitchens", 12.

7 This summary of Falls Hotel's history is based on information included on its menu, December 2005.

Gee describes the swamp and abandoned orchard in "Creeks and Kitchens", 12.

9 Dick Scott, A Stake in the Country - Assid Abraham Corban and his Family, 1892-2002 (Auckland: Reed, 2002). Scott's biographical history of the local Corban family, viticulturists in Henderson from 1892 to 2002, describes the environment, Depression years, and Prohibition. See pp. 73-74 and 76 for an account of the creek and its environment.

10 Gee describes walking to school in "Beginnings", 287. For his description of the creek and associated activities see $284-285$ and 288 .

11 Gee, "The Way", 40.

12 Gee, "Beginnings", 284.

13 Nieuwenhuizen, 5.

14 Holloway, Gee, "Fat Boy", 22.

15 For drownings see Gee, "The Way", 40. On the creek see Gee, "Creeks and Kitchens", 12.

16 Scott, A Stake, p. 76.

17 For this and the following descriptions of Gee's childhood home and the mixed times see Gee, "The Way", 40 and 41.

18 Gee recalls his mother in "Fat Boy", 24.

19 See Nieuwenhuizen, 4 and Gee, "The Way", 41.

20 Wattie, "Maurice Gee" p. 197.

21 Gee, "Beginnings", 286.

22 See Holloway, Gee, "Fat Boy", 23 for Gee’s reference to his father as "Laurie". See "Beginnings", 289 and 286 for references to "Len" and his prowess as a boxer and wrestler.

23 Gee, "The Way", 40.

24 Gee, "The Way", 41.

25 See Gee, "Creeks and Kitchens", 11-12.

26 Tony Simpson, The Sugarbag Years (Wellington: Alister Taylor Publishing Limited, 1974), p. 36. Gee has acknowledged Simpson's definitive account of the Depression as a source of his adult novel The Scornful Moon (2003).

27 For Gee's grandparents see Holloway, Gee, "Fat Boy", 23 and "Beginnings", 285.

28 For biographical detail of Muldoon on which this summary is based see Jon Johansson, Two Titans: Muldoon, Lange and Leadership. (Wellington: Dunmore Publishing, 2005), pp. 49-123.

29 Johansson, p. 51.

30 See Simpson, Sugarbag, pp. 6 and 8 for financial hardship during the Depression.

31 Bill Pearson, "Fretful Sleepers", Fretful Sleepers and Other Essays (Auckland: Heinemann Educational Books, 1974), p. 6.

32 Gee, "The Way", 41.

33 Gee, "Beginnings", 285.

34 Gee describes corporal punishment in Holloway, Gee, "Fat Boy", 23 and "Beginnings", 286- 287.

35 For clothing during the Depression see Simpson, Sugarbag, pp. 18, 75.

36 Gee describes conformity and bullying in "Beginnings", 288; and Holloway, Gee, "Fat Boy", 22.

37 On prohibition and the wine industry see Dick Scott, Pioneers of New Zealand Wine (Auckland: Reed, 2002), p. 117.

38 Keith Sinclair and Wendy Harrex, Looking Back: A Photographic History of New Zealand (Wellington: Oxford University Press, 1978), p. 198.

39 For the prohibitionists' victory, Stout's words and the Crown Law Office statement see Scott, Pioneers, pp. $118,119$.

40 This account of prohibition in Henderson is based on Scott, A Stake, pp. 58-61.

41 Alan Papprill described Assid Corban's circumvention of prohibition during a telephone conversation with Vivien van Rij, March 2004.

42 Sinclair and Harrex, p. 197. 
43 My summary of prohibition in Detroit is based on Jenny Nolan, "Prohibition: How Detroit became a bootlegger's dream town" in The Detroit News

<http://www.detnews.com/history/prohib/prohib.htm>, accessed 3 Dec. 2003.

44 For degradation and despair during the Depression see Simpson, Sugarbag, pp. 70, 74, 78, 29, 7, 120.

45 Gee recalls the Depression in "Creeks and Kitchens", 14.

46 For the Depression see Gee, "Beginnings", 289; Nieuiwenhuizen, 4; and Holloway, Gee, "Fat Boy", 23.

47 This and the following quotation describing radio are from Tony Simpson, The Slump - The Thirties Depression: Its Origins and Aftermath (Auckland: Penguin Books, 1990), pp. 143, 144.

48 See Simpson, Sugarbag, pp. 13, 85.

49 See Scott, A Stake, p. 119.

50 On early movies in New Zealand see David Bateman, New Zealand Yesterdays (Auckland: Reader's Digest, 2001), pp. 146-148.

51 See Scott, A Stake, p. 74.

52 For childhood reading see "Gee, Maurice Gough". In Beneath Southern Skies - New Zealand Children's Book Authors and Illustrators, Tom Fitzgibbon with Barbara Spiers, eds (Auckland: Ashton Scholastic, 1993), p. 67.

53 Gee describes early movies in Henderson in "Beginnings", 292.

54 Gee, "The Way", 42.

55 van Rij, Gee, "Interview".

56 For Gee's description of the swagman and creek see Niewwenhuizen, 5.

57 George Plumb uses the term "fatness of the soul" to describe the "complacency and selfishness and greed" of some of the people in Emslie". See Gee, Plumb, p. 54.

58 See Wattie, p. 443.

59 Gee's comments appear in Nieuwenhuizen, 5.

60 Gee, "The Way", 40.

61 Gee, "The Way", 40.

62 Gee describes his parents in "The Way", 41 and Holloway, Gee, "Fat Boy", 23.

63 Gee acknowledged his "straight steal" of Sargeson's story in van Rij, Gee, "Interview".

64 See Frank Sargeson, "An Affair of the Heart". In The Stories of Frank Sargeson (Auckland: Penguin Books, 1982), pp. 43-51.

65 Gee has commented: "I've got a list of popular songs of those days and I think I found one called 'Old Fashioned Mother' so I thought I'd better find out the words of this. So I went down to the library and found a book that had the full text of various popular songs". van Rij, Gee, "Interview".

66 Gee acknowledges Muskie's dubious relationships with Verna and his mother as similar to Marwick's relationship to his mother in van Rij, Gee, "Interview".

67 The character of Black Jack featured in many Westerns during the Depression including Black Jack (1927), The Broncho Twister (1927), Good Morning Sheriff (1930), Beyond the Rockies (1932), and Gun Law (1933).

68 Scarface (1932), Howard Hawks, dir. (DVD, The Aro Street Video Shop, Welllington, 2008).

69 Laurel and Hardy Way Out West, Universal Pictures, 1937 (DVD, The Aro Street Video Shop, Wellington, 2008).

70 For the influence of film on Gee's writing see Manhire, Maurice Gee, p. 14.

71 We might be reminded of Paul Prior's description of himself: "I've been incomplete. I've got this sense of being hollow. I keep shifting from thing to thing. That's why I have to have a den. To stop me being completely slippery. Lightweight”. See Gee, In my Father's Den, p. 131.

72 For west Auckland as the wild west see "The Wild West - Waitakere Ranges Regional Park" in Metro (Auckland: ACP Media Ltd, June 2004), p. 85.

73 Nieuwenhuizen, 4.

\section{Chapter 6}

1 Maurice Gee, Orchard Street (Auckland: Viking, 1998). All quotations from Orchard Street are from this edition.

2 Foe memories of Newington Road and neighbours see Gee, "Beginnings", 284-292 and Gee, "Creeks and Kitchens", 23.

3 A local resident and former neighbour of the young Gee and his family has identified Newington Road's houses and their inhabitants to Vivien van Rij, December 2005.

4 The second local resident, also a neighbour of the young Gee and his family, described Newington Road and its inhabitants to Vivien van Rij, December 2005. 
5 The first resident has recalled the joining of the road's two ends and Gee's neighbours on its eastern side.

6 The second informant has recalled Gee's mother and father.

7 The first informant has recalled Gee's father as a builder, boxer, and owner of a racehorse.

8 The second informant has recalled Gee's brothers and their nicknames.

9 Gee, "Creeks and Kitchens", 23.

10 The first informant has recalled Gee's brother's employment in the bank and the Pinkneys.

11 The second informant recalled the Pinkneys' garden and trips to England.

12 van Rij, Gee, "Interview".

13 On the Cold War mentality in New Zealand see King, p. 427.

14 Mein Smith, p. 181.

15 Steve Maharey and Mike O’Brien (eds), Alternatives: Socialist Essays for the 1980s (Palmerston North: Massey University, 1986), p. 2.

16 See Mein Smith, p. 201.

17 This account of New Right ideology draws on Mein Smith, pp. 209-211.

18 For reforms under Bolger, see Maharey, p. 12 and Mein Smith, pp. 12-13.

19 See Mein Smith, pp. 209.

20 For Lange's words see Johansson, p. 125.

21 See Johansson, pp. 175-176. For the ill effects of the deregulatory environment see p. 138.

22 For the changing relations of workers and employers see Mein Smith, pp. 210-211.

23 See Chris Kenny in The Big Blue, ed. David Grant (Christchurch, Canterbury University Press, 2004), pp. 141-142.

24 For a comparison of the Douglas and Holland governments see Mein Smith pp. 177, 213-4, 224.

25 Redmer Yska in Grant, p. 25.

26 For Holland as "a puppet" see Jock Phillips in Grant, pp. 170-171. For Holland's courtship of the American dollar see Bill Andersen in Grant, p. 115.

27 Sandra Lee in Grant, p. 127.

28 See Phillips in Grant, p. 171.

29 Andersen discusses fascism and capitalism in Grant, p. 117.

30 See Chris Kenny in Grant, pp. 144-145.

31 See Lee in Grant, p. 128.

32 On the lockout see Jock Barnes' memoirs, Never a White Flag (Wellington, Victoria University Press, 1998).

33 In van Rij, Gee, "Interview" Gee's claims to being "an old socialist [ . . . ] an unreconstructed socialist, well, reconstructed to a certain extent".

34 Maurice Gee, Crime Story (Auckland: Penguin, 1994), p. 23. For a discussion of the setting of Crime Story during the Rogernomics era see Lawrence Jones, "Most Significant Work in NZ Realism", New Zealand Books 4/3 (September 1994), 7.

35 For the development of trade unionism and the Labour Party see Richard Evans, Socialism (London: Hamish Hamilton, 1977), pp. 29-70.

36 A reproduction of the original watersiders' certificate of loyalty appears in Dick Scott, Dick Scott: $A$ Radical Writer's Life (Auckland: Reed Publishing (NZ) Ltd, 2004), p. 161.

37 Barnes, p. 14

38 For Freda Barnes during the lockout see Judith Fyfe in Grant, p. 49.

39 On the lockout see Michael Bassett, Confrontation '51: The Waterfront Dispute (Wellington: A.H. \& A.W. Reed, 1972). For top men involved see pp. 256-264.

40 Dick Scott, 151 Days (Auckland: Southern Cross, third (abridged) edition, 1954), p. 14.

41 For the Emergency Regulations see Scott in Grant, pp. 30-31.

42 Maurice Gee quoted the verse from his files during a telephone conversation with Vivien van Rij, 15 July 2005. The original version is held in the Turnbull Library.

43 See Dick Scott in Grant, pp. 30-31.

44 Rona Bailey recalls the printing and delivery of pamphlets and police intrusion in Grant, p. 41-43.

45 See Lee in Grant, p. 127.

46 Scott recalls Goosman's words in 151 Days, p. 49.

47 See Grant, p. 185 for an account of the march on 2 May.

48 Barnes recalls the 18 May conflict in Never a White Flag, pp. 204-205.

49 For the 1 June conflict see Fyfe in Grant, pp. 51-52.

50 Barry Gustafson in Keith Sinclair (ed), The Oxford Illustrated History of New Zealand (Auckland: Oxford University Press, 2001), pp. 277-278.

51 For Nash's stance see Graeme Hunt, Black Prince: The Biography of Fintan Patrick Walsh (Auckland: Penguin Books, 2004), p. 159 and Grant, pp. 101-108.

52 See Grant for numerous examples of "scabs" and "rats". 
53 For Walsh's life on which this summary is based see Hunt.

54 For accounts of Barnes' trial and the wharfies' return to work see Barnes, pp. 227-229 and Grant, p. 187.

55 Gee has described the parrot as "someone who squawks the party line" to Vivien van Rij during a telephone conversation, 15 July 2005.

56 On the Black Shirts see H. R. Kedward, Fascism in Western Europe 1900-45 (London: Blackie, 1969), pp. 86-94 and 133-134.

57 On Radiant Living see "Herbert Sutcliffe 1886-1971". < http://www.nzhistory.net.nz/Gallery/RadiLiv/sutbiog.htm>, accessed 7 June 2005.

58 J. B. Sykes (ed), The Concise Oxford Dictionary Oxford: Clarenden Press, 1982), p. 19.

59 On Nietzsche see Kedward, pp. 6-48.

60 Robert Browning, "Rabbi Ben Ezra". In The Complete Works of Robert Browning, eds John Berkey, Allan C. Dooley, and Susan Dooley (Ohio: Ohio University Press, 1006), p. 226.

61 For Enoch's "Angels' Control of the Elements" see "The Book of Enoch the Prophet" $<$ http://sacred-texts.com/bib/bep/bep04.htm>, accessed 27 June 2008. Significantly, the passage depicts a governing power (God and the heavens), the relationship with the subordinate (the angels and earth), and labour (the angels' fair and even distribution of Heaven's and the storm's many forms of water). Enoch's whole book is included in The Lost Bible.

62 For Lil's quotation see Browning, p. 226 For carpe diem see Browning, p. 232

63 Gee may have had in mind Nature by Ralph Waldo Emmerson (instrumental in the movement of New England Romanticism), whose ideas strongly influence Plumb.

64 Mr Redknapp's quotes from The Pickwick Papers, Chapter XLV, which depicts Mr Pickwick and Sam Weller meeting an ex-prisoner, Alfred Jingle, and observing his broken spirit and tears. Sam comments, "Wonders 'ull never cease. [ . . . I'm wery much mistaken if that 'ere Jingle worn't doin' somethin' in the water-cart way". See Dickens, The Pickwick Papers (Hertfordshire: Wordsworth Classics, 2000), p. 597.

65 On Jupiter, his moons and stellar structures see Ron Miller and William K. Hartmann, The Grand Tour: A Traveler's Guide to the Solar System (New York: Workman Publishing Company, 2005).

66 For Ganymede, see Miller and Hartmann, pp.108-115.

67 Put briefly, Ossie has been close to Eileen, but has been displaced by Les, who is then threatened with displacement by Bike. Pushed to the outer, Ossie forms a new pair with Teresa. Excluded from both pairs, Bike becomes peripheral, but is caught in their rhythms. In chapter eight, then, Ossie shrinks when faced with Les's revolver (p. 78), but in chapter thirteen becomes more sociable as Bike once was (p. 32). In chapter four the sociable Bike worships Eileen, but in chapter thirteen he wields a revolver as Les has done. Initially aggressive as Bike finally is, but faced with Bike's revolver, Les shrinks as Ossie did earlier when Les wielded the gun (p. 127). Finally peripheral, Bike circles the two sets of pairs and, a microcosmic red dwarf, builds an inner heat and emotionally explodes.

$68 \mathrm{Mr}$ Worley, Mr Redknapp and Ossie could also be regarded as representing the three stages of Gee's life.

69 The statue of the Maori chief is based on a real statue in Auckland's Post Office Square.

\section{Chapter 7}

1 Maurice Gee, Hostel Girl (Auckland: Penguin (NZ) Ltd, 1999. All quotations are from this edition.

2 Gee mentions Margaretha's diary in "Talent and Truth". See Michael Laws, "Books", The Dominion (5 May 2001), 27.

3 Gee describes using Margaretha Gee's diary as a source for Hostel Girl in Denis Welch, "Gee Gee: Maurice Gee's brilliant plagiarisms of Maurice Gee”. New Zealand Listener (12 May 2001), 58-59. Gee has advised Vivien van Rij that Margaretha's diary ia unavailable for public scrutiny (Crofton Downs Mall, Wellington, May 2006).

4 Oswald Chettle Mazengarb, "Report of the Special Committee on Moral Delinquency in Children and Adolescents” (Wellington: R.E. Owen, Government Printer, 1954).

5 On Mazengarb, moral forces, and moral chaos in 1950s New Zealand see Redmer Yska, All Shook Up (Auckland: Penguin Books, 1993), pp. 68-70.

6 For a commentary on the Mazengarb Report see Janet Soler "That Incredible Document Commonly Known as The Mazengarb Report” in Sites 19 (Spring, 1989), 22-32.

7 See Mazengarb, pp. 25 and 13.

8 Mazengarb, p. 4.

9 This summary of the Parker and Hulme case is based on Julie Glamuzina \& Alison Laurie, Parker \& Hulme: A Lesbian View (Auckland: New Women’s Press, 1991), pp. 62-63. See also Yska, pp. 60-63.

10 Mazengarb, pp. 8, 49.

11 See Mazengarb, pp. 44, 43, 39. 
12 On the detrimental effects of popular culture see Mazengarb, pp. 18, 20, 21.

13 On the role of the media, particularly Truth, in the 1950s' moral panic see Roy Shuker and Roger Openshaw with Janet Soler, "Youth, Media and Moral Panic in New Zealand".

Delta Research Monograph 11 (Palmerston North: Department of Education, Massey University, 1990), pp. 1-7, 19-30.

14 For a survey of baby boomers and the counter culture see Mein Smith, pp. 191-193.

15 Maurice Gee discusses his domestic arrangements with Brian Boyd in "Maurice Gee". In In the Same Room: Conversations with New Zealand Writers (Auckland: Auckland University Press, 1992), p. 161.

16 My summary of the protest movement and changing women's roles is based on Mein Smith's survey, pp. 191-193 and 237-240.

17 Mein Smith, p. 102.

18 Neville Bonner, "Sister Elizabeth Kenny" < http://www.abc.net.au/bth/australians/ekenny.htm>, accessed 22 Nov. 2005.

19 See King, pp. 376-380 for a brief account of homosexuality in New Zealand.

20 Peter Lewis, The Fifties (London: Heinemann, 1978), pp. 7-8.

21 Gordon McLauchlan describes conservative New Zealand in The Passionless People (Auckland: Cassell, 1976). See p. 167.

22 This description of the Eastern Hutt Valley draws on Yska, pp. 45-47.

23 McLauchlan, p. 170.

24 McLauchlan, pp. $14-15$.

25 This summary of American popular culture and traditional culture is based on Lewis, pp. 49-58, 119, 127-142.

26 For an account of the "wild ones" see Yska, pp. 108-127.

27 On rock ' $n$ roll and milkbar cowboys see Yska, pp. 128-149.

28 See Yska, pp. 45-50 for sex scandals in the Hutt Valley.

29 See Maureen Molloy, "Science, Myth and the Adolescent Female: The Mazengarb Report, the ParkerHulme Trial, and the Adoption Act of 1955" in Women's Studies Journal 9/1 (The Women's Studies Association of New Zealand, March 1993), 8.

30 For the teenage murderers of 1955 see Yska, pp. 153-194.

31 Stanley Cohen examines the United Kingdom's mods and rockers in Folk Devils and Moral Panics. The Creation of the Mods and Rockers (Oxford: Martin Rol, 1980).

32 See Yska, p. 46.

33 Yska, pp. 63-64.

34 Mirams' account of the New Zealand movie scene during the forties is included in Gordon Mirams, Speaking Candidly: Films and People in New Zealand (Hamilton: Paul's Book Arcade, 1945). For another view of Mirams' censorship see Yska, pp. 111-127.

35 For Engel's comments and the three hangings of 1955 see Yska, pp. 153-194.

36 See Shuker, p. 99 and A.E. Manning; The Bodgie: A Study in Abnormal Psychology (Wellington: A.H. \& A.W. Reed, 1958).

37 Brigadoon, Vincente Minnelli, dir., MGM (Video, The Aro Street Video Shop, Wellington).

38 Mildred Pierce, Michael Curtiz, dir., Warner Brothers (Video, The Aro Street Video Shop, Wellington).

39 This summary of film noir draws on a variety of sources: Toni Glasson and John Carroll, Exploring Film as Text (Australia: Rigby Heinemann, 1992), p. 4; "Film Noir:

<http://www.filmsite.org/filmnoir.html>, accessed 24 April 2006; "Film Noir"

< http://www.crimeculture.com/Contents/Film\%20Noir.html.>, accessed 24 April 2006; "Film Noir" in Wikepedia, the Free Encyclopedia <http://en.wikipedia.org/wiki/Film noir.>, accessed 24 April 2006; "Mildred Pierce" < http://www.nicksflickpicks.com/mildred.html>, accessed 22 Nov. 2005; "Mildred Pierce" < http://www/dvdta;1/cp,/dvds.avant/s706pie.rce.html>, accessed 22 Nov. 2005; and "Mildred Pierce" < http://www.joancrawfordbest.com/filmsmildred.htm>, accessed 22 Nov. 2005.

40 On George Sanders see <http://www.salon.com/07/features/sanders2.thml>, accessed 22 Nov. 2005.

41 William Shakespeare, Two Gentlemen of Verona, IV, ii. In The Complete Illustrated Shakespeare, ed. Howard Staunton (London: George Routledge \& Sons, 1989), I, p. 29.

42 Gee acknowledges reading George Eliot in Boyd, Gee, "Interview", 167. As noted in this thesis' Introduction, Paul Prior draws on George Eliot's Middlemarch for his view of the world. See Gee, In My Father's Den, p. 84.

43 The cover of The Devil Rides Out (first published by Arrow Books in 1954) features a semi-naked demonic figure sitting astride a winged horse. He has the horned head of a goat and is surrounded by predatory birds and serpents. See "Dennis Wheatley - Devil, Witch \& Atlantis"

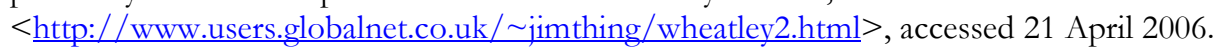


44 "Mairzy Doats", a popular song in 1955, featured nonsense words. Translated, the title reads, "Mares eat oats".

45 William Shakespeare, Hamlet. In Staunton, III, p. 385.

46 For a reproduction of Millais' "Ophelia" see Rose, p. 55.

47 Shakespeare, Hamlet. In Staunton, III, p. 390.

48 Used in the 1970s in the treatment of prostate cancer, dyethylstilbestrol reduced the level of the male hormone, testoserone. But as early as 1953 stilboestrol was discovered to have unpleasant side effects: It could complicate pregnancy, and cause premature labour, miscarriage, a loss of libido and energy, and in men, hair thinning, breast swelling and tenderness. See "Diethylstilbestrol (Stilboestrol)" < http://www.cancerbacup.org.uk/Treatments/Hormonaltherapies/Individualhormonalth...>, accessed 24 Nov. 2005 